DEPARTMENT OF THE INTERIOR

UNITED STATES GEOLOGICAL SURVEY

GEORGE OTIS SMITH, DIRECTOR

\title{
BULAETIN 447
}

MINFRAL RESOURCES

$\mathrm{OF}$

JOHNSTOWN, PENNSYLVANIA AND VICINITY

BY

W. C. PHALEN

AND

LAWRENCE MARTIN

SURVEYED IN COOPERATION WITH THE TOPOGRAPHIO AND GEOLOGIO SURVEY COMMISSION OF PENNSYLIVANIA

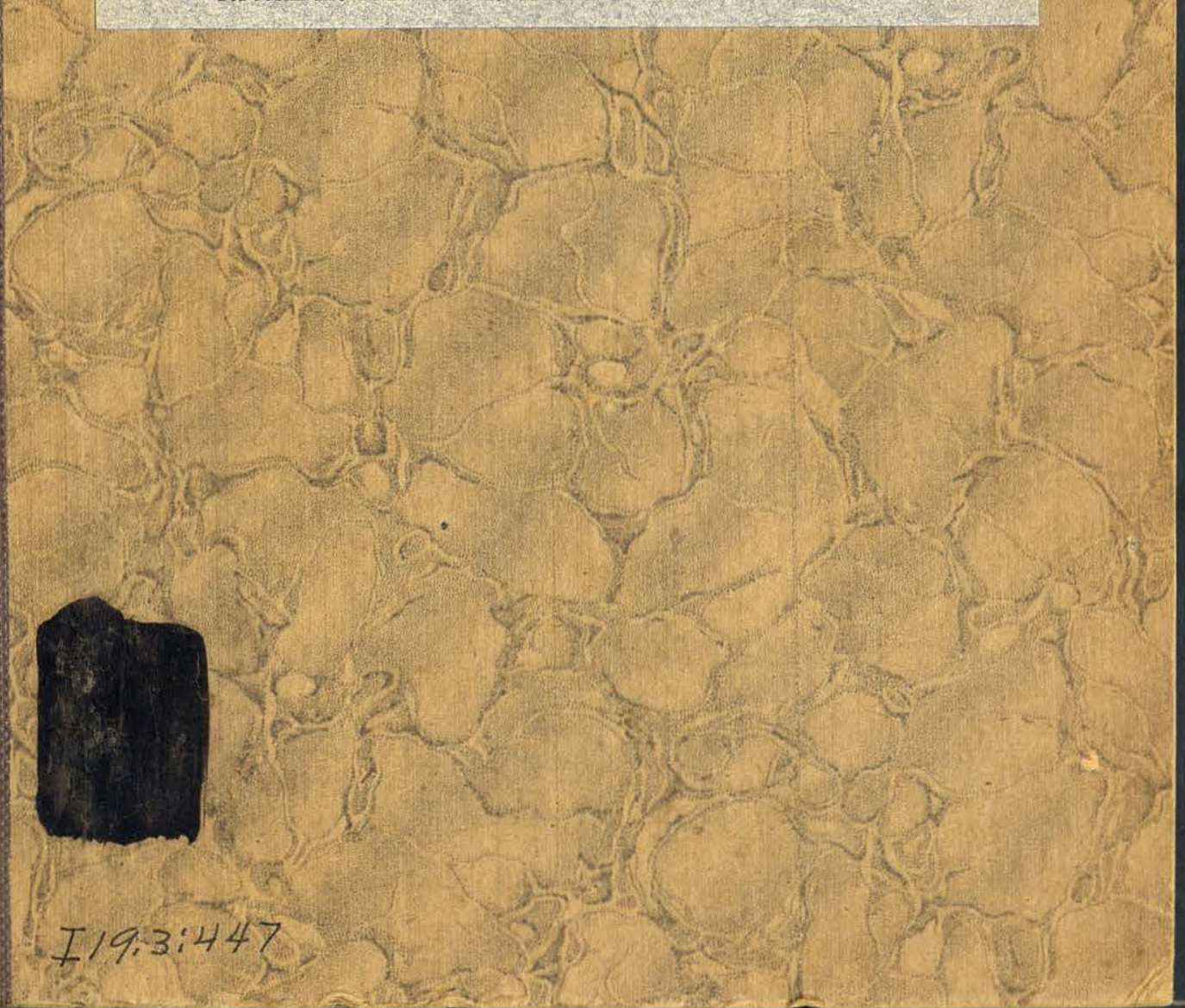




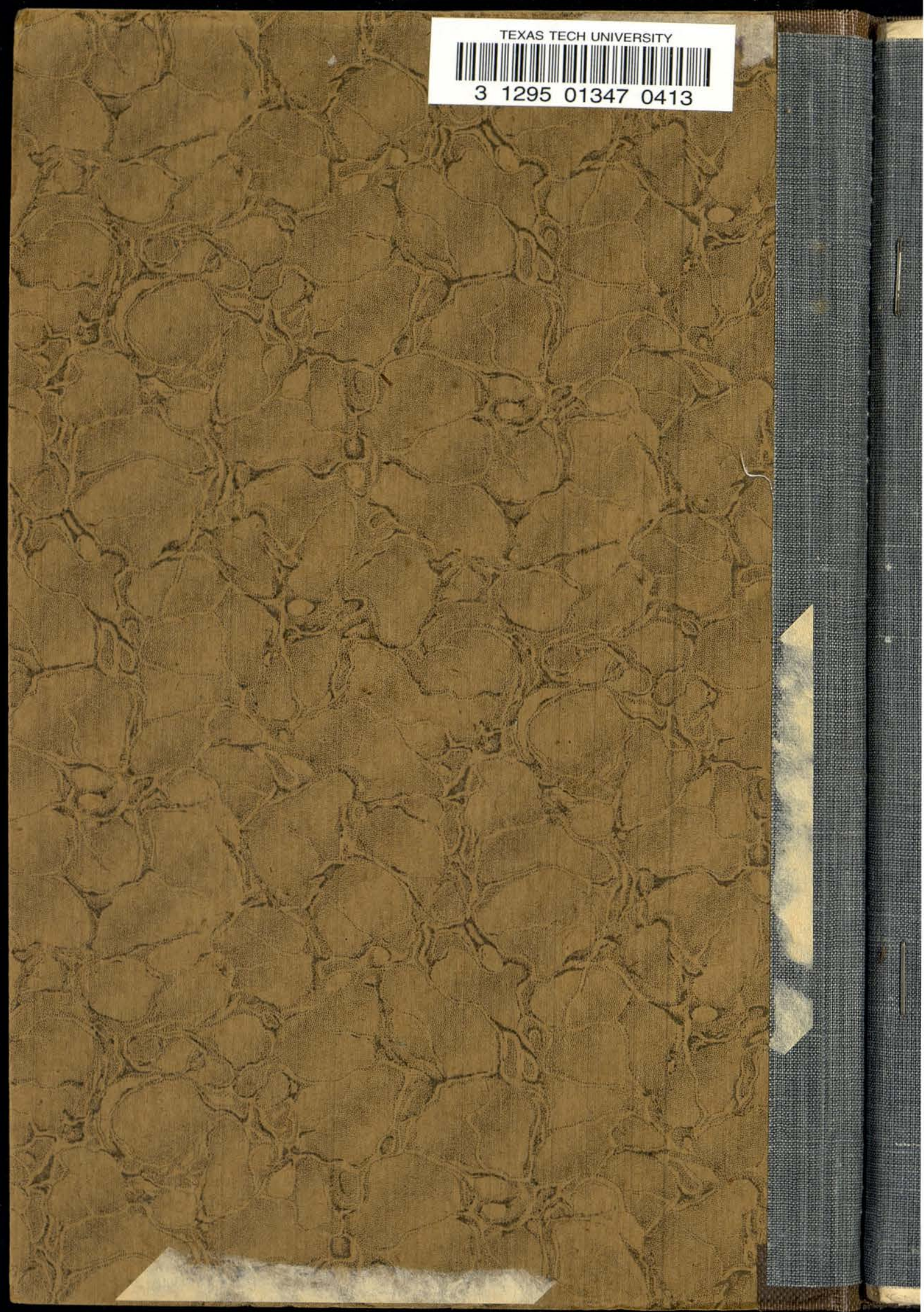




\section{$A D D=9862$}

DEPARTMENT OF THE INTERIOR

UNITED STATES GEOLOGICAL SURVEY

GEORGE OTIS SMITH, DIRECTOR

BuLLetix 447

MINERAL RESOURCES

OF

\section{JOHNSTOWN, PENNSYLVANIA AND VICINITY}

BY

W. C. PHALEN

AND

LAWRENCE MARTIN

SURVEYED IN COOPERATTON WITH THE

TOPOGRAPHIC AND GEOLOGIO SURVEY COMMISSION OF PENNSYLVANIA

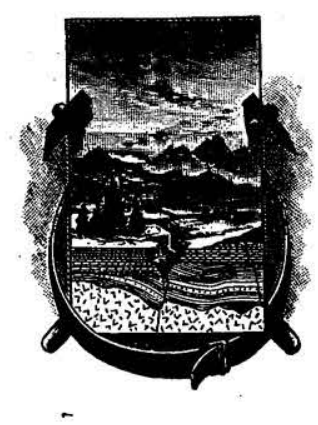

WASHINGTON

GOVERNMENT PRINTING OFFICE

1911

LIDKARY

TEXAS TECHNOLOGICAL COLLEGE

LUBBOCK, TEXAS 



\section{CONTENTS.}

Introduction Page.

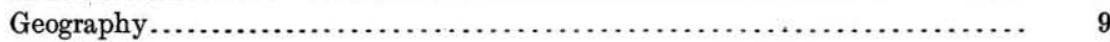

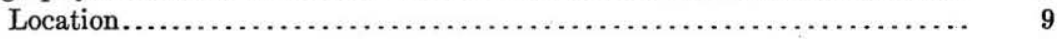

Commercial geography....................................... 9

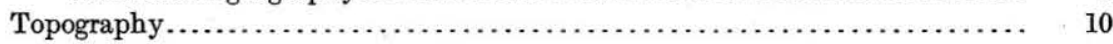

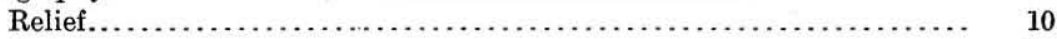

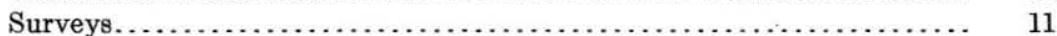

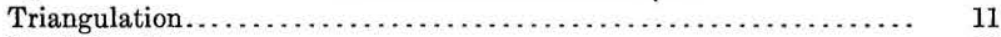

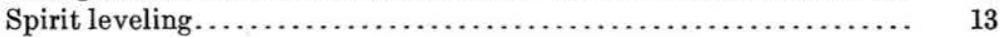

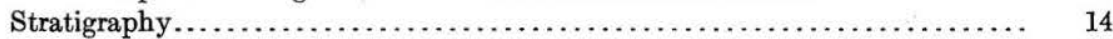

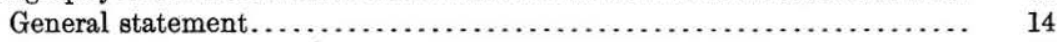

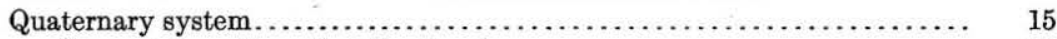

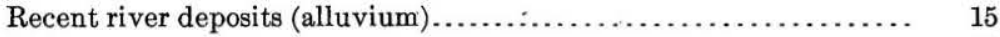

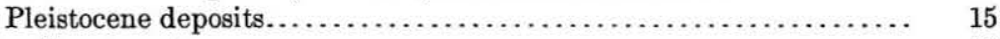

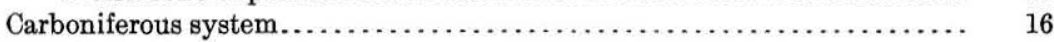

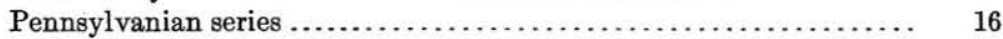

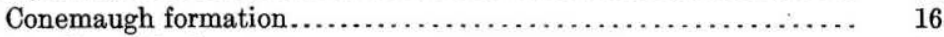

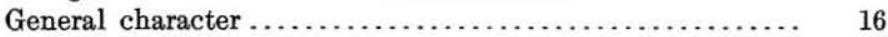

Detailed description............................... 18

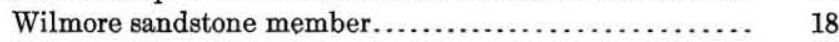

Summerhill sandstone member................. 18

Morgantown ("Ebensburg") sandstone member......... 19

Harlem (?) coal.............................. 19

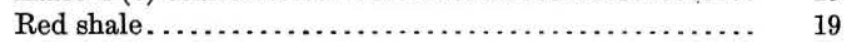

Saltsburg sandstone member.................... $\quad 19$

Buffalo sandstone member................... 20

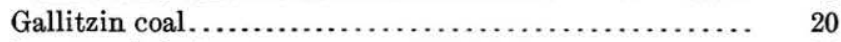

Lower red shales............................. $\quad 20$

Mahoning sandstone member...................... 20

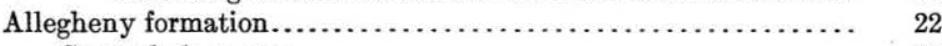

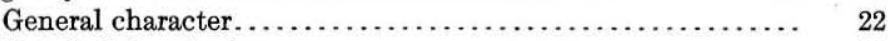

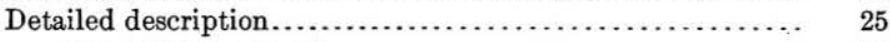

Upper Freeport coal....................... $\quad 25$

Upper Freeport limestone member............... 25

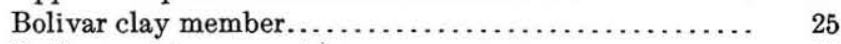

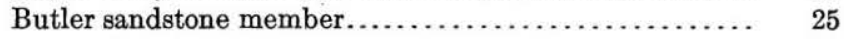

Lower Freeport coal............................... $\quad 25$

Lower Freeport limestone member................ $\quad 25$

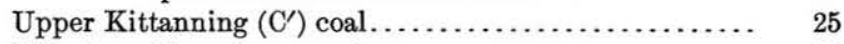

Johnstown limestone member.................... $\quad 26$

Coals between Upper and Lower Kittanning coals...... $\quad 26$

Lower Kittanning coal......................... $\quad 27$

Lower Kittanning clay member................... $\quad 27$

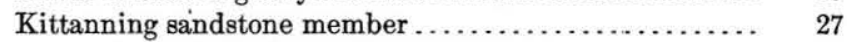

Brookville and Clarion coals.................... 27

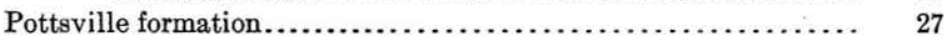


Stratigraphy-Continued. Page.

Carboniferous system-Continued.

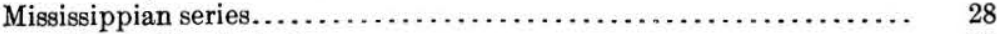

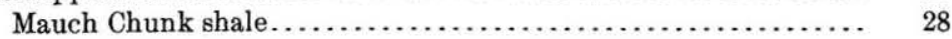

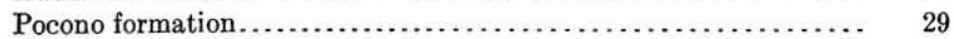

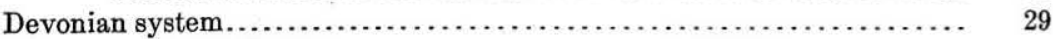

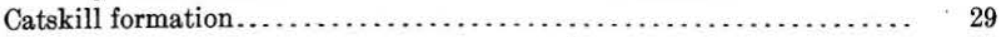

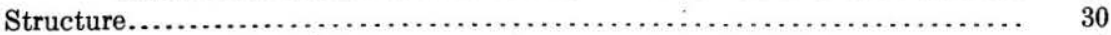

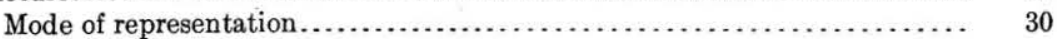

Structure in the Johnstown quadrangle......................... 31

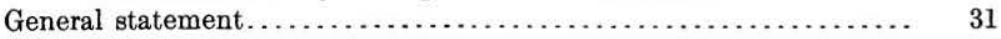

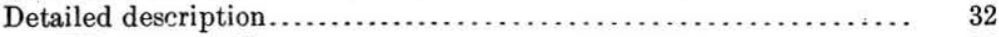

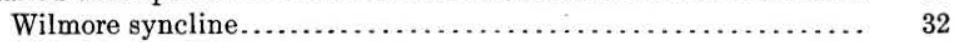

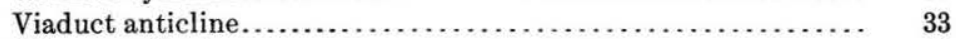

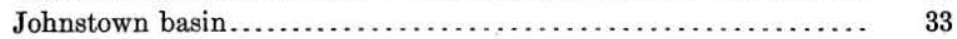

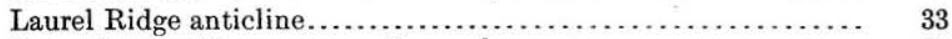

Barnesboro or Westover syncline...................... 34

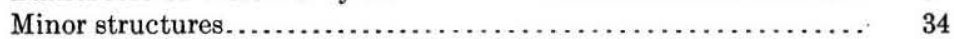

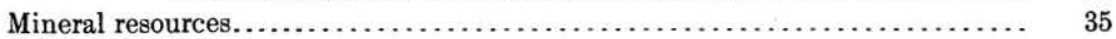

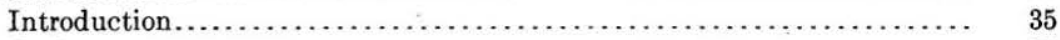

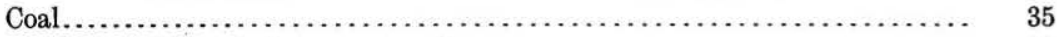

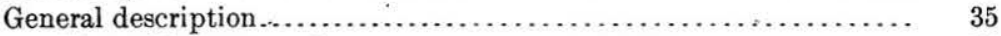

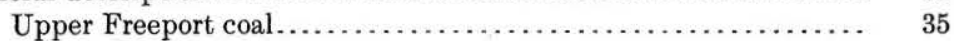

Lower Freeport coal.......................................... 35

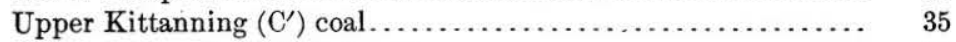

Lower Kittanning (Miller) coal...................... 36

Character and importance........................... 36

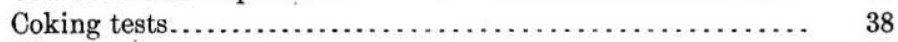

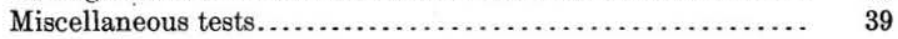

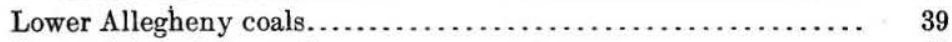

Composition of the coals.............................. 40

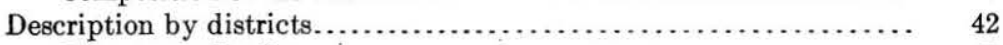

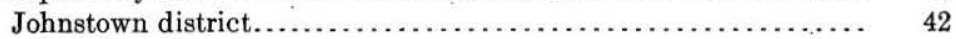

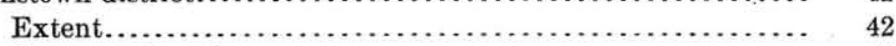

Conemaugh coals............................... 43

Character and distribution.................... 43

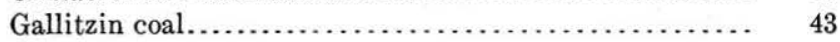

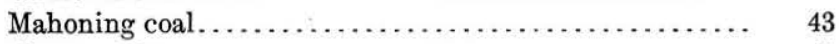

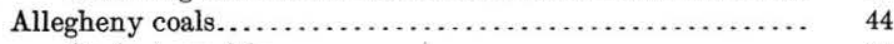

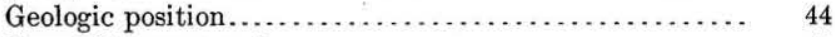

Upper Freeport coal........................... 48

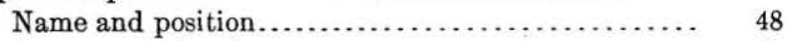

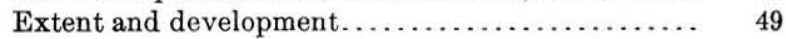

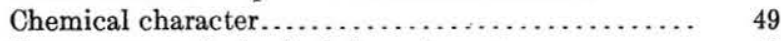

Occurrence and physical character............. 49

Lower Freeport coal......................... 51

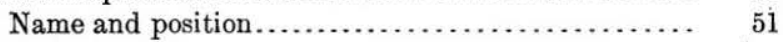

Extent and development.................. '51

Chemical character........................ 51

Occurrence and physical character.............. $\quad 52$

Upper Kittanning coal.............................. 52

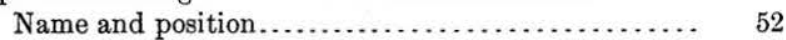

Extent and development.................. 53 
Mineral resources-Continued.

Page.

Coal-Continued.

Description by districts-Continued.

Johnstown district-Continued.

Allegheny coals-Continued.

Upper Kittanning coal-Continued.

Chemical character......................... 54

Occurrence and physical character............... 56

Middle Kittanning coal......................... $\quad 56$

Lower Kittanning coal........................ $\quad 57$

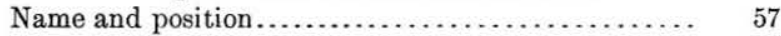

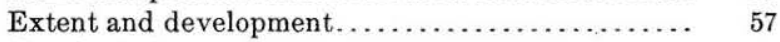

Chemical character......................... $\quad 58$

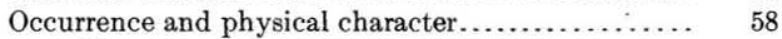

Lower coals............................ $\quad 60$

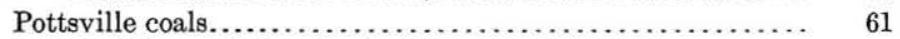

South Fork-Mineral Point district. . . . . . . . 61

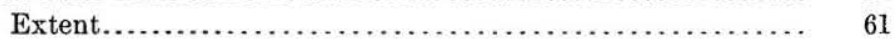

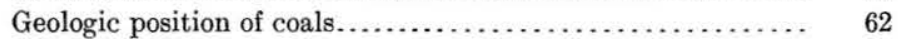

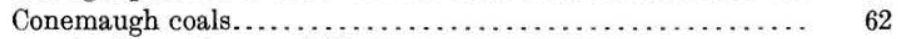

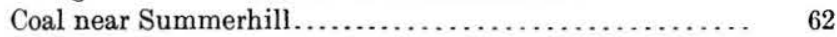

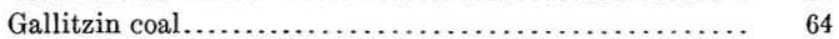

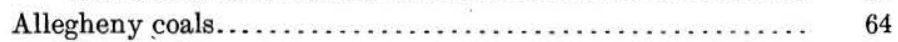

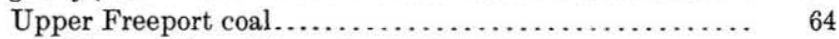

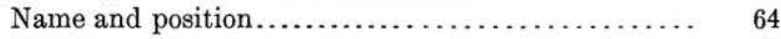

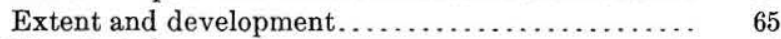

Chemical character.......................... 65

Occurrence and physical character.............. 66

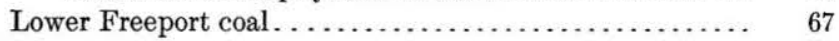

Upper Kittanning (Cement) coal................ $\quad 67$

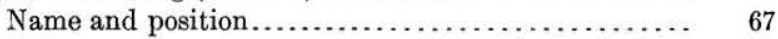

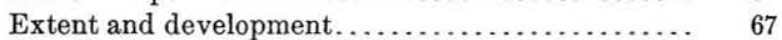

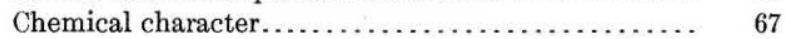

Occurrence and physical character.............. 68

Lower Kittanning (Miller) coal................. $\quad 69$

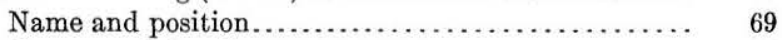

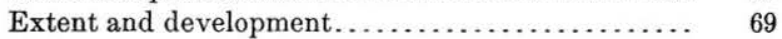

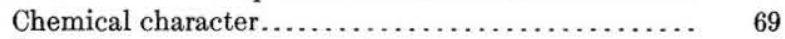

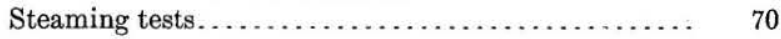

Coking tests. . . . . . . . . . .

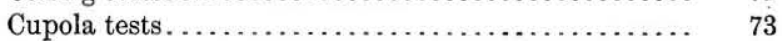

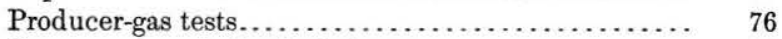

Occurrence and physical character............. $\quad 76$

Lower Allegkeny coals..................... $\quad 77$

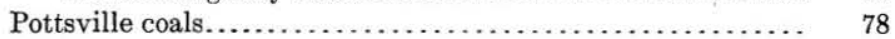

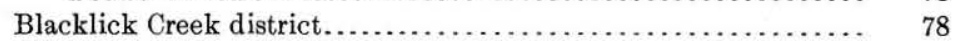

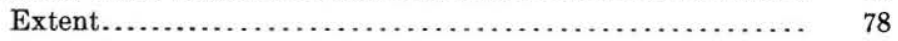

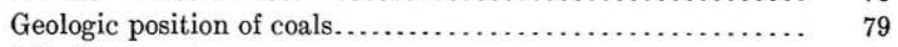

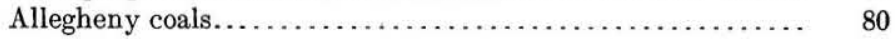

Lower Freeport (D) coal....................... 80

Name and position........................ 80

Extent and development.................. 81

Occurrence and physical character............ 81 
Mineral resources-Continued. Coal-Continued.

Description by districts-Continued.

Blacklick Creek district-Continued.

Allegheny coals-Continued.

Middle Kittanning (C) coal.................... $\quad .82$

Lower Kittanning (B) coal.................... 82

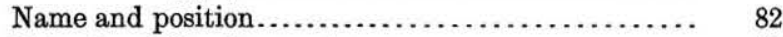

Extent and development................... 83

Chemical character......................... 83

Steaming tests.............................. 83

Coking tests. ................................ 85

Producer-gas test............................ $\quad 86$

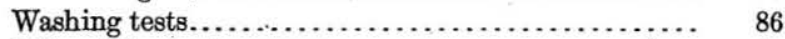

Briquetting tests................................... 87

Occurrence and physical character............. 88

Lower Allegheny coals........................ $\quad 89$

Windber district. ................................... 91

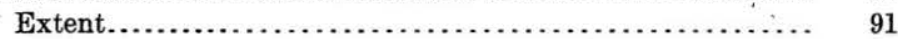

Geologic position of the coals. ..................... 91

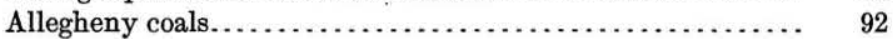

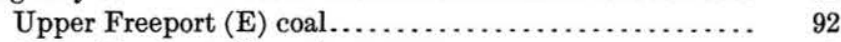

Lower Freeport (D) coal.................... $\quad 93$

Upper Kittanning $\left(C^{\prime}\right)$ coal $\ldots \ldots \ldots \ldots \ldots \ldots \ldots \ldots \ldots . \quad 93$

- Middle Kittanning (C) coal ....................... 94

Lower Kittanning (Miller or B) coal.............. 94

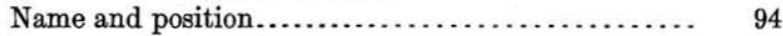

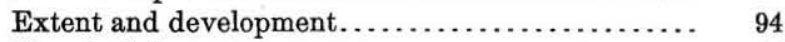

Chemical character....................... 95

Occurrence and physical character............... 95

Lower Allegheny coals...................... $\quad 95$

Conemaugh Furnace district. ........................ 96

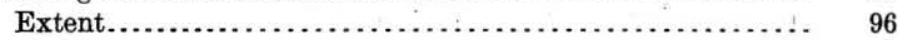

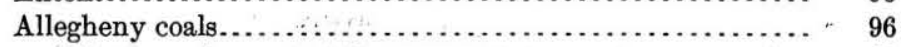

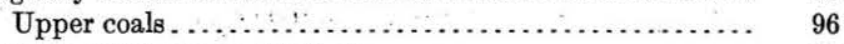

Lower Kittanning (B) coal...................... 97

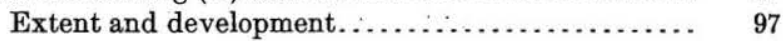

Chemical character.......................... 97

Steaming tests................................ 98

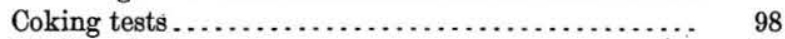

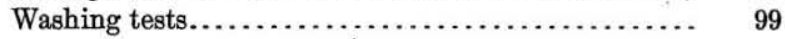

Briquetting tests......................... 99

Occurrence and physical character............. 101

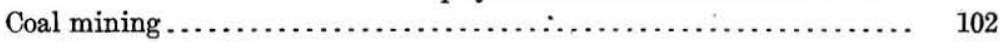

Room and pillar system ............................. 102

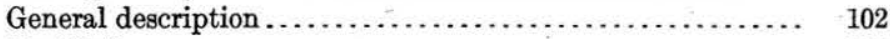

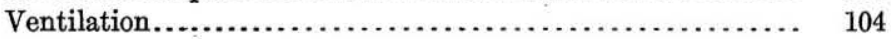

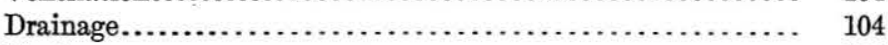

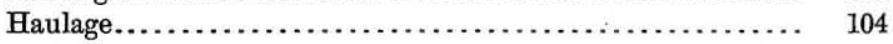

Mining methods.................................... 105

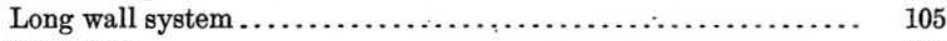

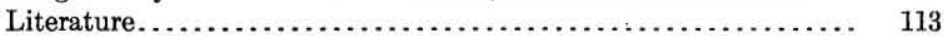


Mineral resourceg-Continued. Page.

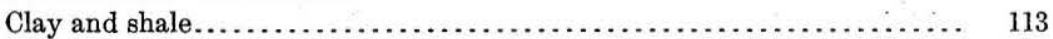

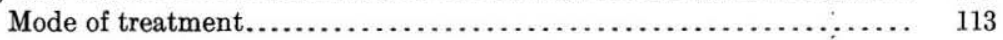

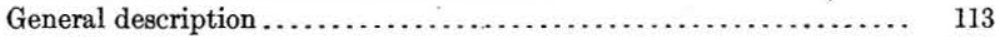

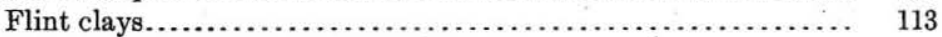

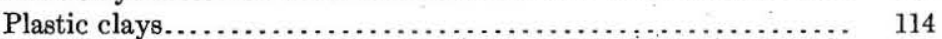

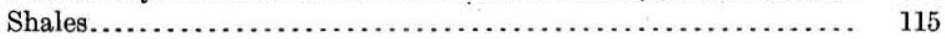

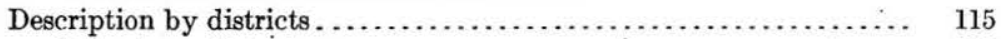

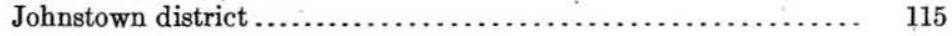

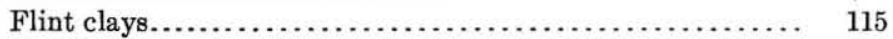

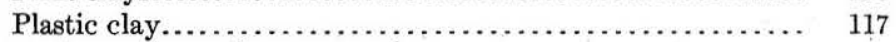

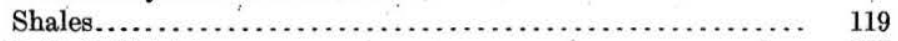

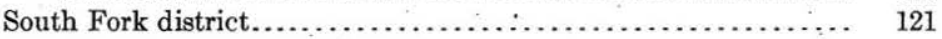

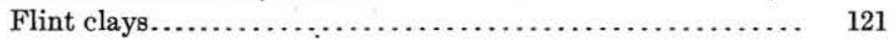

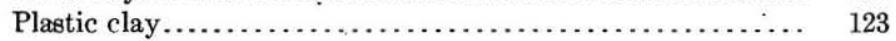

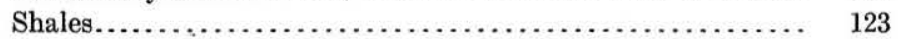

Blacklick Creek district........................... 124

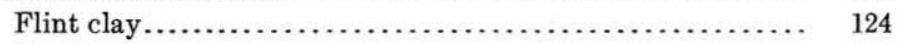

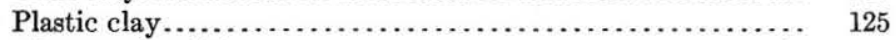

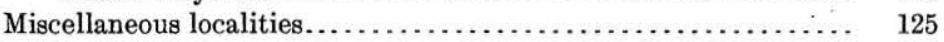

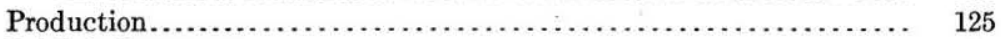

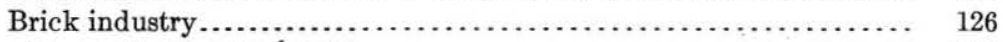

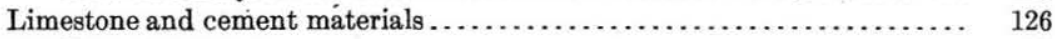

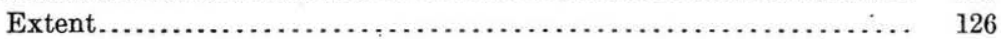

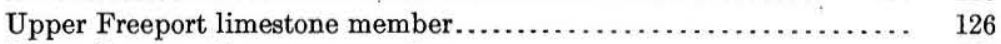

Lower Freeport limestone member ........................ 126

Johnstown limestone member............................ 127

Building stone, paving blocks, and concrete materials .............. 129

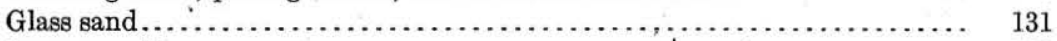

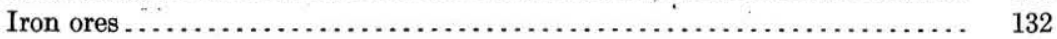

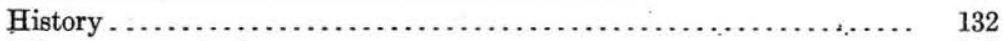

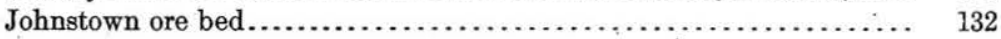

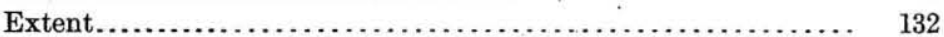

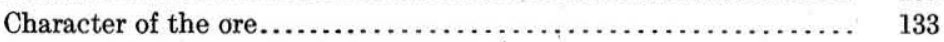

Physical features of the bed $\ldots \ldots \ldots \ldots, \ldots \ldots \ldots \ldots \ldots \ldots \ldots \ldots$

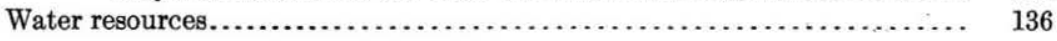

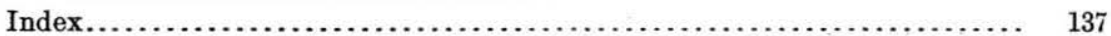

\section{ILLUSTRATIONS.}

Plate I. Economic and structural map of the Johnstown quadrangle, Penn-

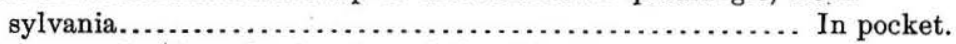

II. Key map showing the location of the Johnstown quadrangle with reference to the entire Appalachian coal field................

III. $A$, South Fork and washed away dam; $B$, Sandstone near base of Conemaugh formation near Johnstown....................

IV. $A$, Exposure of Lower Freeport coal on Stony Creek near trolley bridge, $B$, Country bank of the better class on the Upper Kittanning coal near Mineral Point. 
Plate V. A, Typical exposure of Mauch Chunk shale at the viaduct between South Fork and Mineral Point; $B$, Shale quarry of B. H. Campbell, north of Sheridan, at the Mercer horizon.....................

VI. $A$, Detailed structure of the Loyalhanna limestone; $B$, Loyalhanna limestone (top member of Pocono formation) at summit of Ebensburg (Viaduct) anticline, Mineral Point.......................

VII. $A$, Exposure of Upper Kittanning coal and Johnstown limestone member on Stony Creek, near mine of Valley Coal and Stone Company; $B$, Upper Freeport coal and overlying shales and base of Mahoning sandstone at the south portal of the Baltimore and Ohio Railroad tunnel, Stony Creek..............................

FigURE 1. Sketch map showing location of triangulation stations on which survey of Johnstown quadrangle is based.....................

2. Skeleton sections showing coals in Allegheny formation and the

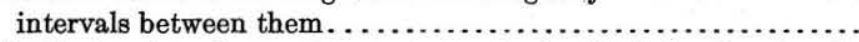

3. Sketch showing the great irregularity in detail of the structure in parts of the Johnstown quadrangle and the marked regularity in detail in other parts...................................

4. Sections of the Upper Freeport (E or Coke Yard) coal in the Johnstown district.........................................

5. Sections of the Lower Freeport (D or Limestone) coal in the Johnstown district.......................................

6. Sections of Upper Kittanning ( $\mathrm{C}^{\prime}$ or Cement) coal in the Johnstown

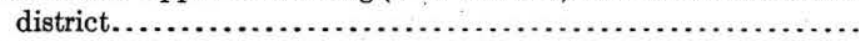

7. Sections of the Lower Kittanning (Miller or B coal) in the Johns-

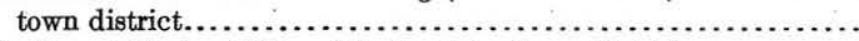

8. Section of Clarion $\left(\mathrm{A}^{\prime}\right)$ coal in the Johnstown district...............

9. Sections of Upper Freeport (E or Lemon) coal near South Fork....

10. Sections of Upper Freeport coal along the southeastèrn margin of the Wilmore Basin......................................

11. Sections of Upper Kittanning (Cement or $C^{\prime}$ ) coal in South ForkMineral Point district. ................................

12. Sections of Lower Kittanning (Miller or B) coal in South ForkMineral Point district..................................

13. Section of the Brookville (A) coal at mine of J. H. Wickes, South Fork................................................

14. Sections of Lower Freeport (D) coal along Blacklick Creek.........

15. Sections of Lower Kittanning (Miller or B) coal in the Blacklick Creek district.........................................

16. Sections of Upper Kittanning (Cement or $\mathrm{C}^{\prime}$ ) coal in the Windber district..............................................

17. Sections of Lower Kittanning (Miller or B) coal in the Windber district.................................................

18. Sections of Lower Kittanning (Miller or B) coal in Conemaugh Furnace district......................................

19. Diagram illustrating the room and pillar method of mining in the Johnstown quadrangle ...................................

20. Plan showing long-wall method of mining as employed at Vinton collieries Nos. 1 and 3 , Vintondale.........................

21. Plan of workings, single long-wall conveyor system . .......... 106

22. Plan of workings, triple long-wall conveyor system.............. 108 



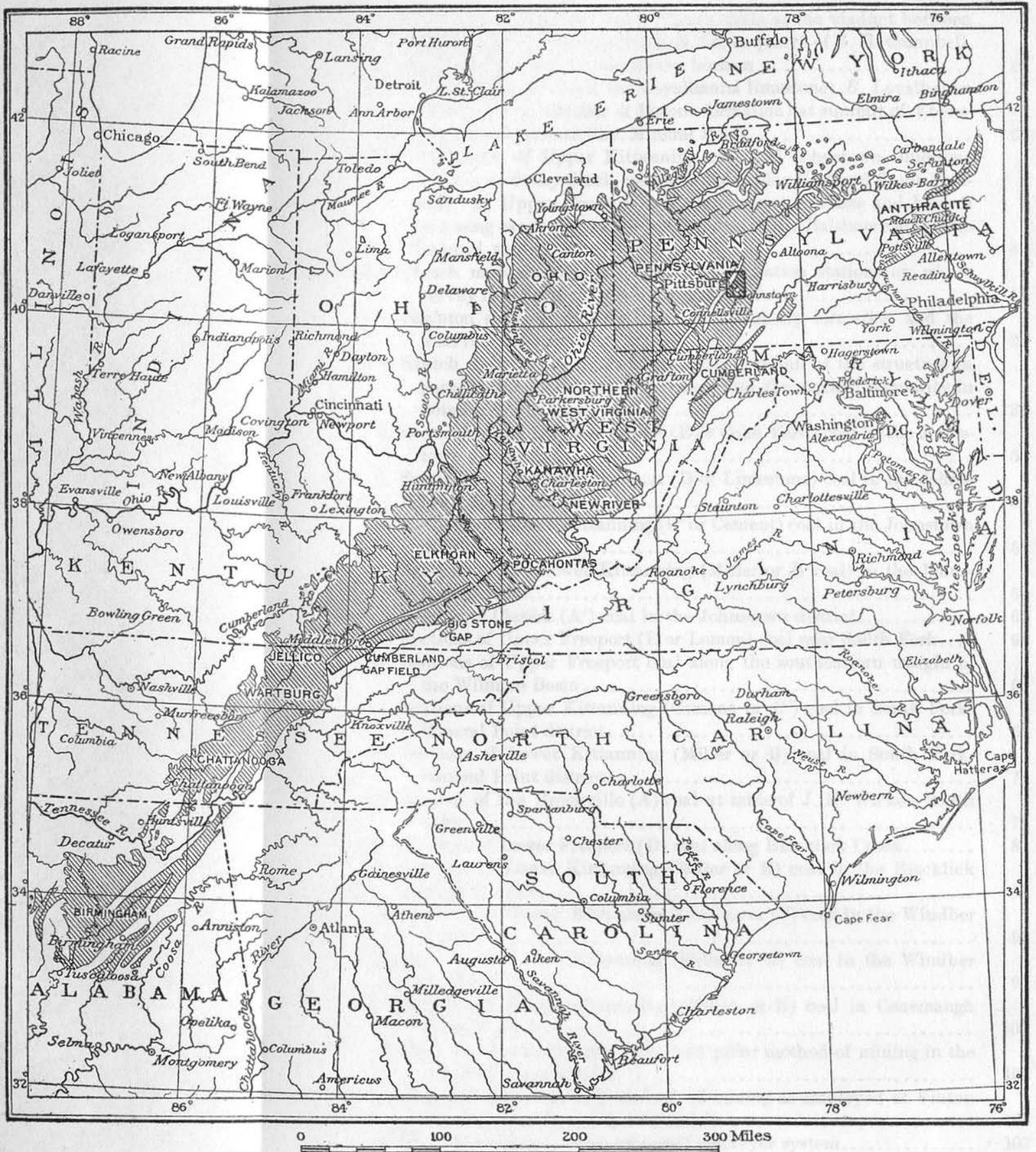

KEY MAP SHOWING LOCATION OF THE JOHNSTOWN QUADRANGLE WITH REFERENCE TO THE ENTIRE APPALACHIAN COAL FIELD. 


\section{MINERAL RESOURCES OF JOHNSTOWN, PENNSYLVANIA, AND VICINITY.}

By W. C. Phalen and Lawrence Martin.

\section{INTRODUCTION.}

This report is one of a number of bulletins and geologic folios containing the results of geologic investigations carried on by the United States Geological Survey in cooperation with the Topographic and Geologic Survey Commission of Pennsylvania. Several papers based on this work, for which the State paid one-half the cost, have been or will soon be published by the State; others are in preparation for publication by the United States Geological Survey.

The field work on which this bulletin is based was done in the summer of 1906 by W. C. Phalen, assisted by Lawrence Martin. George H. Ashley, under whose supervision the work was done, visited the field and went over some of the more critical points.

\section{GEOGRAPHY.}

Location.-The Johnstown quadrangle is situated in southwestcentral Pennsylvania, mostly in Cambria County, but extending also over small parts of Somerset, Westmoreland, and Indiana counties. (See Pl. I, pocket.) Its area is about 228 square miles. It lies near the eastern edge of the Allegheny Plateau province and near the northeastern edge of the great bituminous coal field that extends from the southern part of New York to northern Alabama; its position in this field is shown in Plate II.

Commercial geography. - This quadrangle lies in the plateau region west of the Allegheny Front. Its most important streams are Conemaugh River (formed by the union of Stony Creek and Little Conemaugh River at Johnstown), Blacklick Creek and its South Branch, and South Fork of Conemaugh River. Conemaugh River has long afforded one of the most available highways of communication across the region from the coast to the Middle West; the first railroad (the old Portage and Canal route) and the main line of the Pennsylvania Railroad have both used this valley. The development of the iron 
resources of the region was thus early stimulated, and in turn an impetus was given to the development of the coal resources, until at the present time Johnstown and the neighboring towns are among the leading coal and iron centers of western Pennsylvania.

Stony Creek flows northward, in its course forming part of the boundary between Somerset and Cambria counties, this part of its course lying entirely within the Johnstown Basin. The South Fork of Conemaugh River heads near the summit of Allegheny Mountain, near the Cambria-Bedford county line in the Ebensburg quadrangle, which adjoins the Johnstown quadrangle on the east. South and North branches of Blacklick Creek join near Vintondale and the main stream continues westward along the northern edge of the area. In a general way the drainage of the quadrangle flows from east to west. The main structural and to a less noticeable extent the main topographic features trend northeast and southwest. The drainage and structure thus intersect at a fairly large angle-a condition which has proved of vast economic importance, for it has resulted in the cutting of deep valleys and the exposing of valuable clay and coal beds. Moreover, it has made possible the exploitation on a large scale of the mineral wealth by drifting along the outcrop-a much safer and cheaper method than shafting and one tending to the most rapid development of a coal region. The streams have determined the location of the local railway systems and have made their construction fairly easy.

\section{TOPOGRAPHY.}

RELIEF.

- The form of the surface of the Johnstown quadrangle bears a close and striking relation to the geology and structure. The highest points in the area are along the crest of Laurel Ridge, which south of Conemaugh River is more than 2,700 feet high at a few points. Laurel Ridge is a structural feature - that is, it is dependent on the character of the rocks brought to the surface by the structure. These are largely the sandstones of the Pocono and Pottsville formations. Where rocks of this character cover the surface the country is wild and surface cultivation is out of the question. Farther north along the ridge the sandy sediments dip below drainage level and the rocks of the Allegheny formation ("Lower Productive Coal Measures") and the Conemaugh formation ("Lower Barren Coal Measures") appear in the hills, as, for instance, along South Branch of Blacklick Creek. The changes in vegetation and general conditions accompanying the gradual disappearance of the sandy beds below the surface are noticeable north of South Branch of Blacklick Creek, and in this region the country is almost all under cultivation.

In the southeast corner of the quadrangle the highest hills are a little more than 2,700 feet high. Here also the beds are involved in 
the structural uplift along the front of Allegheny Mountain, and the rocks along the crest of the mountain are chiefly the same sandstones as occur on Laurel Ridge.

The lowest points in the area are on Conemaugh River, at the western edge of the quadrangle. At Conemaugh Furnace station the elevation is $1,134.54$ feet. The extremes in the topography are well brought out near by, for Conemaugh River in descending from 1,185 feet at Johnstown to 1,135 feet at Conemaugh Furnace flows through a gorge the hills on either side of which rise 1,600 feet higher.

The greater portion of the area has an elevation between the extremes given above. In detail the surface is decidedly hilly, but most of the hill slopes are rather gentle, especially back from the main drainage channels. The badly dissected character of the ridge has, however, an important bearing on the availability and exploitation of the natural resources of the region. There is very little level land in the quadrangle, what there is being confined almost solely to the lower stretches of Blacklick Creek in Indiana County.

Points of equal elevation are represented on the contour map by light-brown lines, which really represent the intersections of hypothetical horizontal planes with the surface of the country. They are placed 20 feet apart and indicate the "lay of the land" with great precision.

SURVEYS.

TRIANGULATION STATIONS.

The topographic work for the map of the Johnstown quadrangle (Pl. I) is based on triangulation stations established by the United States Geological Survey within the boundaries of the quadrangle or comparatively near its borders to the east and north. (See fig. 1.) Descriptions of the exact locations of these triangulation stations are given below:

CHICKAREE, CAMBRIA COUNTY.

On a cleared knob in the central part of Jackson Township, 10 miles by road westward from Ebensburg, 300 yards south of the Chickaree Hill schoolhouse.

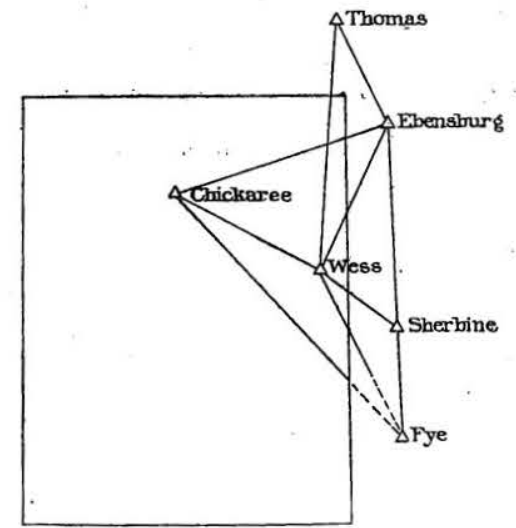

FTGURE 1.-Sketch map showing location of triangulation stations on which survey of Johnstown quadrangle is based.

Station mark: A marble post 34 by 6 by 6 inches set 32 inches in the ground, in the center of top of which is countersunk and cemented a bronze triangulation tablet. 
MINERAL RESOURCES OF JOHNSTOWN, PA., AND VICINITY.

[Latitude $40^{\circ} 26^{\prime} 38.97^{\prime \prime}$. Longitude $78^{\circ} 52^{\prime} 48.29^{\prime \prime}$.]

\begin{tabular}{|c|c|c|c|}
\hline To station- & Azimuth. & Back azimuth. & $\begin{array}{l}\text { Log. dis- } \\
\text { tance. }\end{array}$ \\
\hline 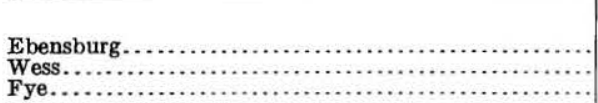 & $\begin{array}{ccc}\circ & , & \prime \prime \\
251 & 24 & 48.82 \\
292 & 00 & 35.81 \\
318 & 31 & 18.78\end{array}$ & $\begin{array}{rcc}\circ & \prime & \prime \prime \\
71 & 30 & 51.47 \\
112 & 04 & 41.22 \\
138 & 37 & 47.50\end{array}$ & $\begin{array}{l}\text { Meters. } \\
\text { 4. } 1425539 \\
\text { 3. } 9833693 \\
\text { 4. } 3303852\end{array}$ \\
\hline
\end{tabular}

EBENSBURG, CAMBRIA COUNTY.

Station is center of cupola of courthouse in Ebensburg.

Station mark: Center of cupola.

[Latitude $40^{\circ} 29^{\prime} 02.07^{\prime \prime}$. Longitude $78^{\circ} 43^{\prime} 29.50^{\prime \prime}$.]

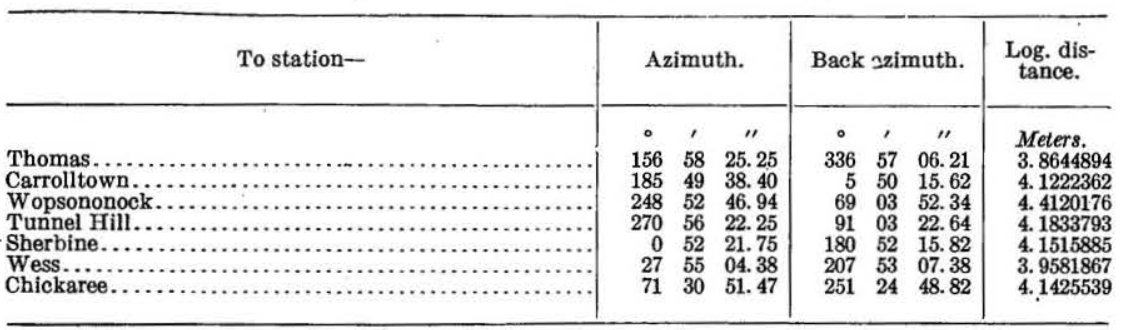

WESS, CAMBRIA COUNTY.

In the northern portion of Croyle Township, 8 miles southwest of Ebensburg, 1 mile west of New Germany, in a pasture owned by Leo Wess. Theodolite elevated 35 feet.

Station mark: A marble post 36 by 6 by 6 inches set 32 inches in the ground, in the center of the top of which is countersunk and cemented a bronze triangulation tablet.

Reference mark: Line fence due north 44 feet distant. Center of big dead tree, N. $65^{\circ} \mathrm{W}$. (magnetic), 31 feet distant.

[Latitude $40^{\circ} 24^{\prime} 41.86^{\prime \prime}$. Longitude $78^{\circ} 46^{\prime} 29.85^{\prime \prime}$.]

\begin{tabular}{|c|c|c|c|c|c|c|c|c|}
\hline . & To station- & · & Azim & auth. & Back a & azim & nuth. & $\begin{array}{l}\text { Log. dis- } \\
\text { tance. }\end{array}$ \\
\hline $\begin{array}{l}\text { Chickaree... } \\
\text { Thomas.... } \\
\text { Ebensburg. } \\
\text { Sherbine.... } \\
\text { Fye......... }\end{array}$ & 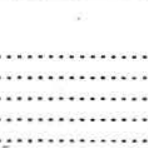 & & $\begin{array}{cc}\circ & , \\
112 & 0 \\
185 & 2 \\
207 & 5 \\
326 & 41 \\
337 & 0\end{array}$ & $\begin{array}{lc} & \prime \prime \\
4 & 41.22 \\
0 & 37.23 \\
3 & 07.38 \\
1 & 29.11 \\
9 & 43.27\end{array}$ & $\begin{array}{r}\circ \\
292 \\
5 \\
27 \\
146 \\
157\end{array}$ & $\begin{array}{l}1 \\
00 \\
21 \\
55 \\
43 \\
12\end{array}$ & $\begin{array}{c}\prime \prime \\
35.81 \\
15.32 \\
04.38 \\
20.03 \\
06.81\end{array}$ & $\begin{array}{l}\text { Meters. } \\
\text { 3. } 9833693 \\
\text { 4. } 1710473 \\
\text { 3. } 9501867 \\
\text { 3. } 8666773 \\
4.1299536\end{array}$ \\
\hline
\end{tabular}

SHERBINE, CAMBRIA COUNTX.

On a small hill having scattering locust trees on its summit, in Croyle Township, about one-fourth mile west of the Summerhill Township line, 2 miles southwest of Wilmore, 2 miles southeast of Summerhill post-office, on land of Aaron Sherbine. Theodolite elevated 28 feet. 
Station mark: A marble post 36 by 6 by 6 inches set 32 inches in the ground, in the center of top of which is countersunk and cemented a bronze triangulation tablet.

[Latitude $40^{\circ} 21^{\prime} 22.50^{\prime \prime}$. Longitude $78^{\circ} 43^{\prime} 38.65^{\prime \prime}$.]

\begin{tabular}{|c|c|c|c|c|c|c|c|}
\hline To station- & \multicolumn{3}{|c|}{ Azimuth. } & \multicolumn{3}{|c|}{ Back azimuth. } & $\begin{array}{l}\text { Log. dis- } \\
\text { tance. }\end{array}$ \\
\hline 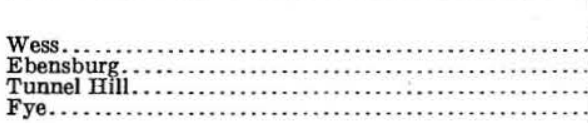 & $\begin{array}{c}\circ \\
146 \\
180 \\
228 \\
349\end{array}$ & $\begin{array}{l}\prime \\
43 \\
52 \\
00 \\
15\end{array}$ & $\begin{array}{c}\prime \prime \\
20.03 \\
15.82 \\
07.85 \\
37.33\end{array}$ & $\begin{array}{r}\circ \\
326 \\
0 \\
48 \\
169\end{array}$ & $\begin{array}{l}\prime \\
41 \\
52 \\
07 \\
16\end{array}$ & $\begin{array}{c}\text { "' } \\
29.11 \\
21.75 \\
13.50 \\
09.98\end{array}$ & $\begin{array}{l}\text { Meters. } \\
\text { 3. } 8666773 \\
\text { 4. } 1515885 \\
\text { 4. } 3183273 \\
\text { 3. } 8058254\end{array}$ \\
\hline
\end{tabular}

FYE, CAMBRIA COUNTY.

[Not occupied.]

A cleared ridge known as the Fye place, owned by the Mountain Coal Company, in Adams Township, 6 miles south of Summerhill and 7 miles southeast of South Fork.

Station mark: A marble post 36 by 6 by 6 inches set 32 inches in the ground, in the center of top of which is countersunk and cemented a bronze triangulation tablet.

Reference mark: The lone locust signal tree 4 feet north of station mark.

[Latitude $40^{\circ} 17^{\prime} 58.79^{\prime \prime}$. Longitude $78^{\circ} 42^{\prime} 48.19^{\prime \prime}$.]

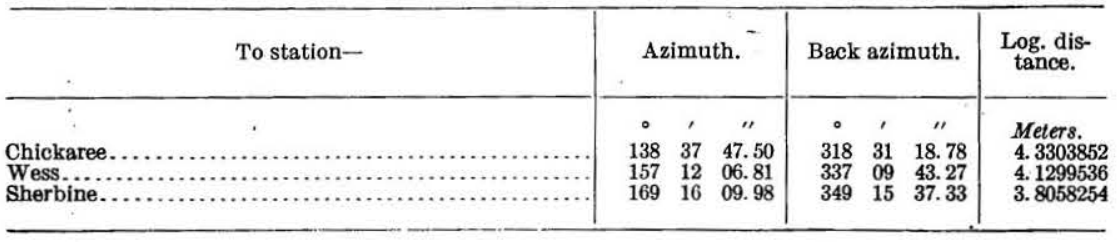

SPIRIT LEVELING.

The topography of the Johnstown quadrangle is shown on Plate I by buff-colored contour lines based on precise levels run by the United States Geological Survey. In running these levels numerous bench marks were established, their elevations being based on an aluminum tablet in the foundation of the Seventh Avenue Hotel, Pittsburg, Pa., marked " 738 Pittsburg, 1899," the elevation of which is now accepted as 738.384 feet above mean sea level. The initial points on which these levels depend are various bench marks along the precise-level lines of the Pennsylvania Railroad, the accepted heights having been determined by the 1903 adjustment.

The work on the Johnstown quadrangle was done by Mr. George Seidel, levelman, in 1902. 


\section{MiNERAL RESOURCES OF JOHNSTOWN, PA., AND VICINITY.}

The descriptions and elevations of these bench marks are given below:

\section{Johnstown south along Baltimore and Ohio Railroad to Ingleside.}

Johnstown, at west end of north parapet of railroad bridge; copper bolt

Feet.

(Pennsylvania Railroad bench mark) ......................... 1, 180.27

Johnstown, east end of south parapet of Pennsylvania Railroad bridge; aluminum tablet stamped "1180 PITTS" ...................... 1, 180.261

Johnstown, railroad ticket office, on window sill; chiseled shelf (Pennsylvania Railroad bench mark) ................................ 1, 187. 60

Johnstown, road crossing at Pennsylvania Railroad station; top of rail..... 1, 184

Johnstown, in front of Baltimore and Ohio Railroad station; top of rail.... 1, 169

Stony Creek, road crossing at station; top of rail.................. 1, 194

Johnstown, 3 miles south of, Baltimore and Ohio Railroad and trolley grade crossing; top of rail. .................................... 1, 191

Kring, road crossing at station; top of rail. ..................... 1,241

Ingleside, 700 feet north of, northeast corner of small railroad bridge; copper bolt marked " 1275 PITTS". . . . . . . . . . . . . . $275.6 \ldots \ldots \ldots \ldots \ldots$

Ingleside northeast along Pennsylvania Railroad via Elkton to Salix.

Scalp Level, 0.45 mile north of, west side of track, 75 feet west of tool house, in large sandstone; aluminum tablet stamped "1719 PITTS"........ 1, 719. 225

Salix, 870 feet north of station, under Pennsylvania Railroad culvert, west wall; bronze tablet stamped " 2050 PITTS" .................... 2, 049.455

Salix, railroad bridge at station, north parapet, east end; aluminum tablet stamped "2077 PITTS". ............................... 2, 077. 762

Seward northeast along Pennsylvania Railroad via Vintondale and Nanty Glo to Ebensburg.

Seward, 0.17 mile west of V. K. tower, railroad bridge No. 226 over Piney Run, north parapet, east end of arch; copper bolt (Pennsylvania Railroad bench mark) ......................................... 1, 091.571

Seward, doorstep of waiting room of station; copper bolt marked "1122 U. S. "'........................................... 1, 122.145

Seward, crossing at station; top of rail......................... 1,120

Wehrum, crossing at station; top of rail......................... 1, 360

Vintondale, 150 feet east of station, iron bridge, south end of west abutment; aluminum tablet stamped "1403 PITTS"........................... 1, 402.741

Twin Rocks, crossing at station; top of high rail.................. 1, 668

Nanty Glo, 200 feet south of station, iron bridge, west end of north abutment; bronze tablet stamped "1706 PITTS" ...................... 1, 705.761

Nanty Glo, crossing at station; top of high rail................... 1,710

Beulah Road, in front of station; top of rail. . . . . . . . . . . . . . .

\section{STRATIGRAPHY.}

GENERAL STATEMENT.

The surface rocks in the Johnstown quadrangle are entirely of sedimentary origin, all of them having been deposited in or by water. They consist of sandstones, shales, limestones, and coal and iron-ore beds, the whole having a thickness of approximately 3,100 to 3,200 
feet. These rocks belong in the Devonian and Carboniferous systems, except for the imperfectly consolidated gravels of the river terraces, which are tentatively regarded as of Pleistocene age, and the recent alluvium of the flood plains. The Carboniferous rocks are of chief importance, as they contain the workable coals and clays. All these rocks will be described in descending order, beginning with the youngest.

QUATERNARY SYSTEM.

RECENT RIVER DEPOSITS (ALLUVIUM).

The alluvium of the streams of this area is the youngest bedded deposit. It consists of fine material, chiefly sand and clay, laid down by the present streams during periods of high water, and is present in varying amounts along most of the streams, though occupying as a rule small areas only. The most important alluvial area is that at the confluence of Conemaugh River and Stony Creek, on which the greater part of the city of Johnstown and its suburbs is located. Other important areas of alluvium are found on Blacklick Creek near the northwestern corner of the quadrangle. All the level land in this part of the quadrangle is under cultivation.

PLEISTOCENE DEPOSITS.

Along Conemaugh River and Stony Creek occur deposits which can not be correlated strictly with the alluvium or recent flood-plain deposits. This material, which consists of rounded bowlders varying up to 2 or 3 feet in greatest dimension, mingled with sand and clay in small quantities, is found at two or more distinct horizons. The lower deposit is well developed along the main line of the Pennsylvania Railroad and is shown in small cuts a short distance east of Mineral Point. On the Baltimore and Ohio Railroad a short distance south of the quadrangle, north of the mouth of Paint Creek, near Kring, and near the suburb of Roxbury are also excellent exposures. At the quarry of B. H. Campbell, north of Sheridan, rounded bowlders occur 100 feet above the level of the Pennsylvania Railroad. This deposit is similar in all respects to the lower one occurring along Stony Creek. These bowlders show in the foreground of Plate V, $B$ (p. 28). The material is considered to be Pleistocene in age. It has no economic importance. 
16 MINERAL RESOURCES OF JOHNSTOWN, PA., AND VICINITY.

CARBONIFEROUS SYSTEM.

PENNSYLVANIAN SERIES.

CONEMAUGH FORMATION.

GENERAL CHARACTER.

The Conemaugh formation includes the rocks lying below the Pittsburg coal and above the Upper Freeport coal. A nearly complete section of these rocks was obtained from drill records and by handlevel work along the Pennsylvania Railroad in the deepest part of the Wilmore structural basin. The upper 200 feet or so of the section represents barometric work along the roads in the Ebensburg quadrangle to the east. It has been thought advisable to give the section of the Conemaugh thus obtained in this locality as a matter of record, but it will be understood that such a detailed section necessarily is constant over a very small area. Some of the sandstones, for instance, die out completely within a short distance and other lentils appear in the section either slightly higher up or lower down. In general, local names are applied to such sandstone lentils where their position is known to be fairly well defined in the geologic column.

The section of the Conemaugh formation is as follows:

Section of the Conemaugh formation in the Wilmore Basin.a

\begin{tabular}{|c|c|c|c|}
\hline . & $\begin{array}{l}\text { Thick- } \\
\text { ness. }\end{array}$ & \multicolumn{2}{|c|}{ Total. } \\
\hline & Ft. in. & & in. \\
\hline Sandstones and sandy shale layers with intercalated limestones. . . . . . . . . . . . . . . . . & 200 & 200 & \\
\hline Shale ...... & & 220 & \\
\hline 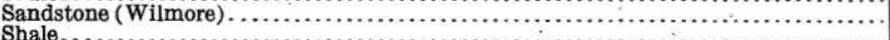 & 17 & 237 & \\
\hline 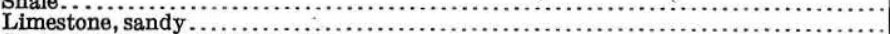 & $\begin{array}{l}5 \\
2\end{array}$ & $\begin{array}{l}242 \\
244\end{array}$ & \\
\hline 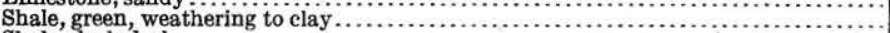 & 23 & $\begin{array}{l}244 \\
267\end{array}$ & \\
\hline Shale, dark drab & & 282 & \\
\hline Sandstone, containing a 10 to 12 inch limestone layer and with a possible coal bloom.. & 6 & 288 & \\
\hline 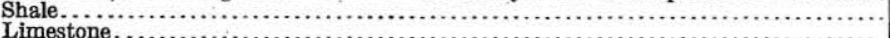 & 10 & 298 & \\
\hline $\begin{array}{l}\text { Limestone } \\
\text { Shale, green. }\end{array}$ & 9 & 307 & \\
\hline Limestone..... & ${ }_{1}^{6}$ & $\begin{array}{l}313 \\
314\end{array}$ & \\
\hline Shale, concretionary & $\frac{1}{2}$ & $\begin{array}{l}014 \\
316\end{array}$ & \\
\hline Fire clay:........... & 1 & 317 & \\
\hline 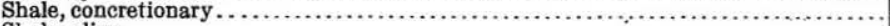 & 4 & 321 & \\
\hline 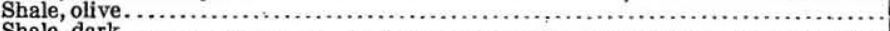 & 1 & 322 & \\
\hline 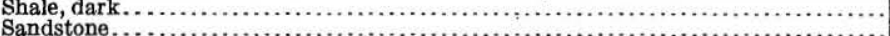 & 10 & 332 & \\
\hline 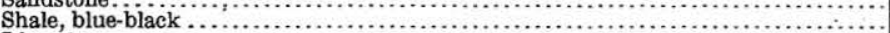 & $\frac{1}{3}$ & $\begin{array}{l}333 \\
336\end{array}$ & \\
\hline Limestone. . & & 339 & \\
\hline Shale & 20 & 359 & \\
\hline ..................... & 45 & 404 & \\
\hline dy and limestone layers... & 30 & 434 & \\
\hline 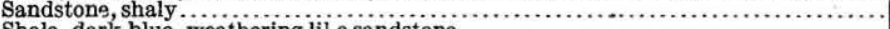 & 25 & 459 & \\
\hline weathering lihe sandstone............................. & 25 & 484 & \\
\hline Sandstone......................... & 2 & $\begin{array}{l}486 \\
489\end{array}$ & \\
\hline ling into s & $\begin{array}{l}3 \\
6\end{array}$ & $\begin{array}{l}489 \\
495\end{array}$ & \\
\hline Sandstone, hard, gray ..) & 25 & 520 & \\
\hline Shäle...................... Morgantown ("Ebensburg”) sandstone member... & $3 \frac{1}{2}$ & 520 & $3 \frac{1}{2}$ \\
\hline $\begin{array}{l}\text { Sandstone, } \\
\text { Shale, sandy } \ldots \ldots \ldots \ldots \ldots \ldots \ldots \ldots \ldots \ldots \ldots \ldots \ldots \ldots \ldots \ldots \ldots\end{array}$ & $5 \frac{1}{2}$ & 527 & $\stackrel{9}{11}$ \\
\hline 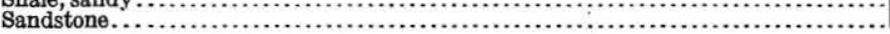 & $\begin{array}{ll}5 & 2 \\
5 & 1\end{array}$ & 536 & \\
\hline
\end{tabular}

a First 200 feet, barometric measurements along roads; section hand-leveled from 200 to 495 feet: below 495 feet record obtained from 2 bore hole on the Pennsylvania Railroad opposite the signal tower between Wilmore and Summerhill. 
Section of the Conemaugh formation in the Wilmore Basin-Continued.

\begin{tabular}{|c|c|c|c|c|}
\hline & \multicolumn{2}{|c|}{$\begin{array}{l}\text { Thick- } \\
\text { ness. }\end{array}$} & \multicolumn{2}{|c|}{ Total. } \\
\hline & \multirow{2}{*}{\multicolumn{2}{|c|}{$\underset{9}{F t .} \quad$ in. }} & $\begin{array}{l}F t \text {. } \\
545\end{array}$ & \\
\hline hale Coal (called 600 -foot rider owing to its position at about 600 feet above the Lower & & & \multirow{10}{*}{\multicolumn{2}{|c|}{$\begin{array}{lr}546 & \frac{1}{2} \\
575 & 2 \frac{1}{2} \\
581 & 3 \frac{1}{2} \\
588 & 10 \frac{2}{2} \\
607 & 2 \frac{1}{2} \\
613 & 10 \frac{1}{2} \\
627 & \frac{2}{2} \\
635 & 10 \frac{1}{2} \\
639 & 3 \frac{1}{2} \\
646 & 2\end{array}$}} \\
\hline 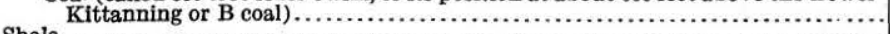 & \multirow{9}{*}{\multicolumn{2}{|c|}{$\begin{array}{rr} & 10 \\
29 & 2 \\
6 & 1 \\
7 & 7 \\
18 & 4 \\
6 & 8 \\
13 & 2 \\
8 & 10 \\
3 & 5 \\
6 & 10 \\
7 & 10\end{array}$}} & & \\
\hline 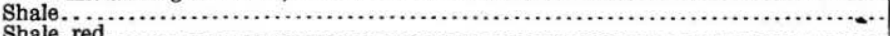 & & & & \\
\hline $\begin{array}{l}\text { Shale, red } \\
\text { Shale }\end{array}$ & & & & \\
\hline 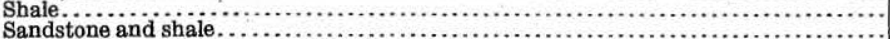 & & & & \\
\hline Shale, calcareous....... & & & & \\
\hline 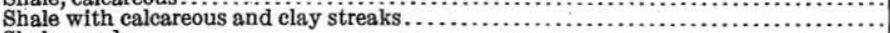 & & & & \\
\hline 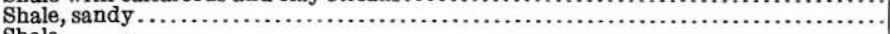 & & & & \\
\hline 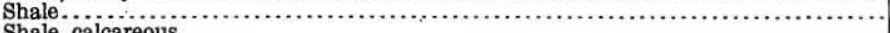 & & & & \\
\hline 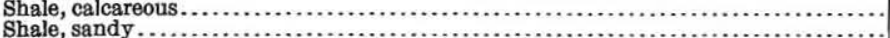 & & & & \\
\hline $\begin{array}{l}\text { Sandstone } \\
\text { Sand }\end{array}$ & \multirow{2}{*}{31} & \multirow{3}{*}{$\begin{array}{l}2 \frac{1}{2} \\
8 \\
5 \frac{1}{2}\end{array}$} & \multirow{2}{*}{$\begin{array}{l}654 \\
685 \\
685\end{array}$} & \multirow{2}{*}{$\begin{array}{lr}\frac{4}{5} & 21 \\
5 & 10 b\end{array}$} \\
\hline 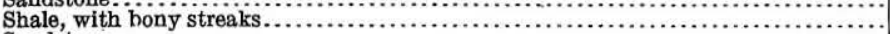 & & & & \\
\hline 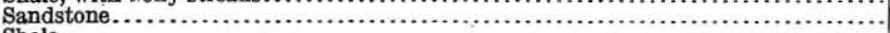 & & & \multirow{8}{*}{$\begin{array}{l}701 \\
706 \\
725 \\
753 \\
765 \\
820 \\
825 \\
832 \\
861 \\
868\end{array}$} & \multirow{5}{*}{$\begin{array}{ll}1 & 4 \\
6 & 2 \frac{1}{2} \\
5 & 2 \frac{1}{5} \\
3 & 3 \\
5 & 6 \frac{1}{2} \\
0 & 9\end{array}$} \\
\hline 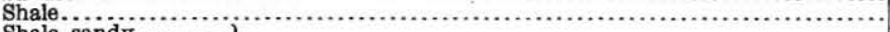 & \multirow{8}{*}{$\begin{array}{r}4 \\
19 \\
28 \\
12 \\
55 \\
4 \\
7 \\
28 \\
7\end{array}$} & \multirow{2}{*}{$10 \frac{1}{2}$} & & \\
\hline Shale, sandy.......... & & & & \\
\hline $\begin{array}{l}\text { Sandstone............. Buffalo sandstone member } \ldots \ldots \ldots \ldots \ldots \ldots \ldots \ldots \ldots \ldots \ldots \ldots \ldots \ldots \ldots \\
\text { Slate and sandstone. }\end{array}$ & & \multirow{6}{*}{$\begin{array}{l}1 \\
3 \\
2 \frac{1}{2} \\
3 \\
6 \\
6 \frac{1}{2} \\
6 \frac{1}{2} \\
11\end{array}$} & & \\
\hline 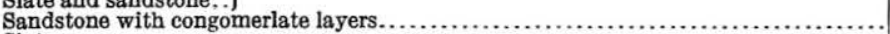 & & & & \\
\hline 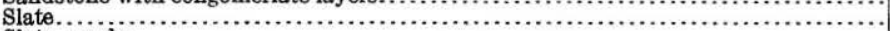 & & & & \\
\hline (n................. & & & & 6 \\
\hline 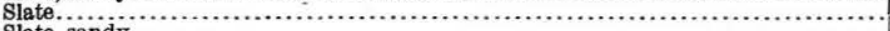 & & & & \\
\hline 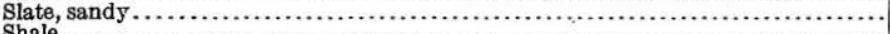 & & & 868 & \\
\hline 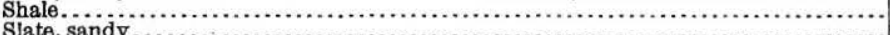 & & $11 \frac{1}{6}$ & & $6 \frac{1}{2}$ \\
\hline 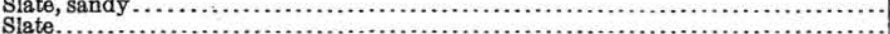 & 11 & & $\begin{array}{l}874 \\
885\end{array}$ & $8^{2}$ \\
\hline Sandston & & 4 & 889 & \\
\hline Shal & 10 & 3 & 899 & 3 \\
\hline Shale & & 11 & 904 & \\
\hline 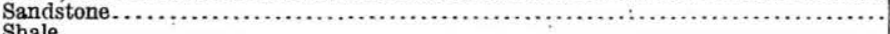 & 10 & 3 & 914 & \\
\hline & & & 922 & 8 \\
\hline sandstone lavers & & $8 \frac{1}{2}$ & 925 & $4 \frac{1}{2}$ \\
\hline sandstone lay & & 111 & 946 & 102 \\
\hline & & 3 & 949 & 1 \\
\hline ................... & 10 & 1 & 959 & \\
\hline & & & 964 & \\
\hline - & & & & \\
\hline
\end{tabular}

With this section may be compared the following section of a part of the Conemaugh, measured by John Fulton, in Prossers Knob, near Johnstown: ${ }^{a}$

Section of part of the Conemaugh formation in Prossers Knob, near Johnstown.

Ft. in.

Shales, olive. . . . . . . . . . . . . . . . . . . . . . . . . . . 17

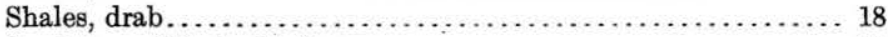

Sandstone, thin bedded .............................. 10

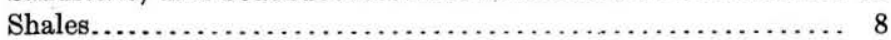

Iron ore, siliceous.................................. 3

Shales, olive and drab............................. 68

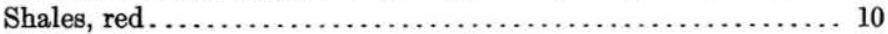

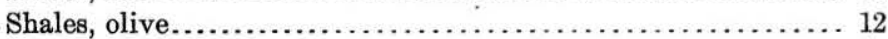

Slate and sandstone. ................................. 10

Sandstone, white. . . . . . . . . . . . . . . $\ldots \ldots \ldots \ldots$

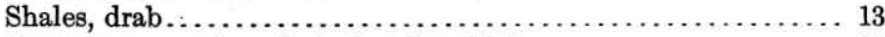

Sandstone, massive, drab, forming cliff.................. 20

Coal. ......................................... 3

a Second Geol. Survey Pennsylvania, Rept. H2, p. 97.

$69516^{\circ}-$ Bull. $447-11-2$ 
MINERAL RESOURCES OF JOHNSTOWN, PA., AND VICINITY.

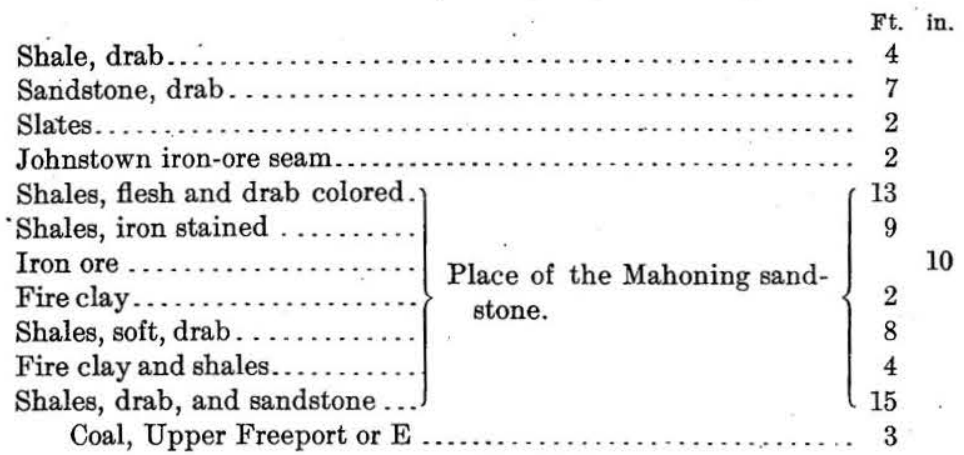

According to the section (pp. 16-17), the Conemaugh is nearly 1,000 feet thick, this estimate, however, being subject to the question of the correct correlation of the Pittsburg coal. It is made up essentially of shales and sandstones, with a few beds of limestone. Streaks of coal are present here and there, but only locally are they of sufficient thickness and purity to be worked even in a small way. Fire clay, both plastic and flint, occurs in the formation in certain parts of the area. A bed of iron ore described in the reports of the Second Geological Survey of Pennsylvania as the Johnstown ore has been found on Mill. Creek, north and west of Johnstown, and near the position of the old Cambria furnace at the base of Laurel Hill; it lies 50 feet above the Upper Freeport coal. Considerable historical importance attaches to this ore body, for its presence determined the beginning of the iron industry near Johnstown and undoubtedly influenced the present vigorous development of the coal.

DETAILED DESCRIPTION.

The higher portion of the Conemaugh in the Johnstown quadrangle is made up of sandstones and shales, with occasional beds of limestone. As it has been found difficult to correlate these sandstones with the typical members in the Pittsburg district and Allegheny Valley, they are here referred to by the local names given them in the Ebensburg quadrangle, which lies immediately east of the area under discussion.

Wilmore sandstone member.-The highest of these sandstones was called by Butts ${ }^{a}$ the Wilmore sandstone. It shows in the top of the first railway cut west of Wilmore and in the neighboring hills. Its position with reference to the Upper Freeport coal is indicated in the section on pages 16-17. It is usually not more than 20 feet thick.

Summerhill sandstone member.- Next comes the Summerhill sandstone member, whose base lies 560 feet above the Upper Freeport coal. It varies from 30 to 45 feet in thickness. It was named by 
Butts from the village of Summerhill, in the eastern part of the Johnstown quadrangle. It outcrops conspicuously in all the hills between Wilmore and Summerhill, especially in a bluff east of the latter town. It is as a rule decidedly laminated in appearance, differing in this respect from the massive Morgantown ("Ebensburg") sandstone below.

Morgantown ("Ebensburg") sandstone member.-The next lower stratum of note in this area is a sandstone which Butts called the Ebensburg, but which in this report will be termed the Morgantown sandstone member. This sandstone lies between 400 and 450 feet above the Upper Freeport coal in the southeastern part of the quadrangle and probably less than 400 feet above it in the northern part. It is excellently developed near Elton in the Johnstown area.

Harlem (?) coal.-The Morgantown sandstone is closely underlain by a thin coal known as the 600 -foot rider, as it is usually 600 feet above the Lower Kittanning coal. It outcrops near the old dam site on South Fork of Conemaugh River (Pl: III, $A$ ). It is possible that this corresponds to the Harlem or Friendsville coal, but this correlation is provisional, as it is hazardous to attempt close correlation with the upper portions of the Conemaugh in the western part of the State.

Red shale.-The next lower stratum persistent enough to be traced with certainty is a band of red shales 30 feet or less in thickness. These occur in nearly all parts of the quadrangle, though the distance of their top above the Upper Freeport coal is not constant, varying from 300 to 400 feet. They may correspond to the red shale in the western part of the State, to which I. C. White has given the name Pittsburg red shales.

Saltsburg sandstone member.-Around Johnstown the top of what is regarded as the representative of the Saltsburg sandstone member lies about 300 feet above the Upper Freeport coal. It is very nearly 50 feet thick and is fairly massive in the hills east of the town. It is underlain in this region by a thin band of reddish and purple shales.

In the southeastern part of the quadrangle the Saltsburg horizon is for the most part below drainage level, but several apparently carefully kept drill records give an excellent idea of its character. Its top is here 300 feet above the Upper Freeport coal, and it is about 50 feet thick. It is underlain by 30 to 40 feet of shales containing a coal (the Bakerstown bed) or, in one section, two coals separated by 25 feet of shales and sandy shales. Red shale also appears in this shale interval, and not more than 25 feet above this a slightly calcareous bed, very thin, may possibly represent the Upper Cambridge limestone. Both near Johnstown and in the southeastern part of the quadrangle these sandstones in places become sandy shales and 
merge imperceptibly with the beds above or below, so that it is diffcult or impossible to locate their bases and tops in the records.

Buffalo sandstone member.-In the South Fork district the top of the Buffalo sandstone member is about 200 feet above the Upper Freeport coal. As nearly as can be ascertained from the road sections, the sandstone consists of a single member. It appears prominently along the Pennsylvania Railroad near Ehrenfeld, where the débris from it is massive, and is well exposed in the shallow railroad cuts west of Summerhill station. Compactly bedded thick and thin flags are very characteristic of this stratum in the eastern part of the Johnstown quadrangle and farther east in the Ebensburg quadrangle.

Along Blacklick Creek in the northwestern part of the quadrangle there appears in the section a very massive sandstone, whose top is 200 to 235 feet above the Lower Freeport coal and 80 and 95 feet, respectively, above the Mahoning coal and Johnstown ore bed. This sandstone probably corresponds to the Buffalo sandstone member. It is exceedingly massive, forming débris comparable to that from the Pottsville. It makes a very prominent appearance north of Vintondale and to the west in Indiana County.

Gallitzin coal.-The Gallitzin coal ranges from 70 to 125 feet above the top of the Upper Freeport coal in the region around Johnstown. In some of the diamond-drill records from the hills east of the city it appears about 110 feet above the top of the Upper Freeport coal. In some of the sections a coal appears as near the Upper Freeport as 70 feet. Where there is but a single coal in the lower 125 feet of the Conemaugh and it is as near to the.Upper Freeport as 70 feet there is always doubt as to whether it should be regarded as the Gallitzin or as a lower coal. The Gallitzin coal is not a commercial bed and has not been worked except for local use in any part of the quadrangle.

Lower red shales.-The Gallitzin coal is underlain by a thin band of red or variegated shales, which are well exposed along the road ascending to Pleasant Hill in the western part of Johnstown. In some records of the drill holes put down to the east of the city these shales have been called variegated.

Mahoning sandstone member.-The Mahoning member is composed of sandstones, shales, and coals lying at the base of the Conemaugh formation between the Gallitzin coal and the Upper Freeport coal (top of the Allegheny formation). It is well exposed in the hills about Johnstown and to the south along Stony Creek, near South Fork, and near Blacklick Creek.

At the tunnel of the Baltimore and Ohio Railroad south of Johnstown the following clear-cut section of the lower part of this member was obtained: 


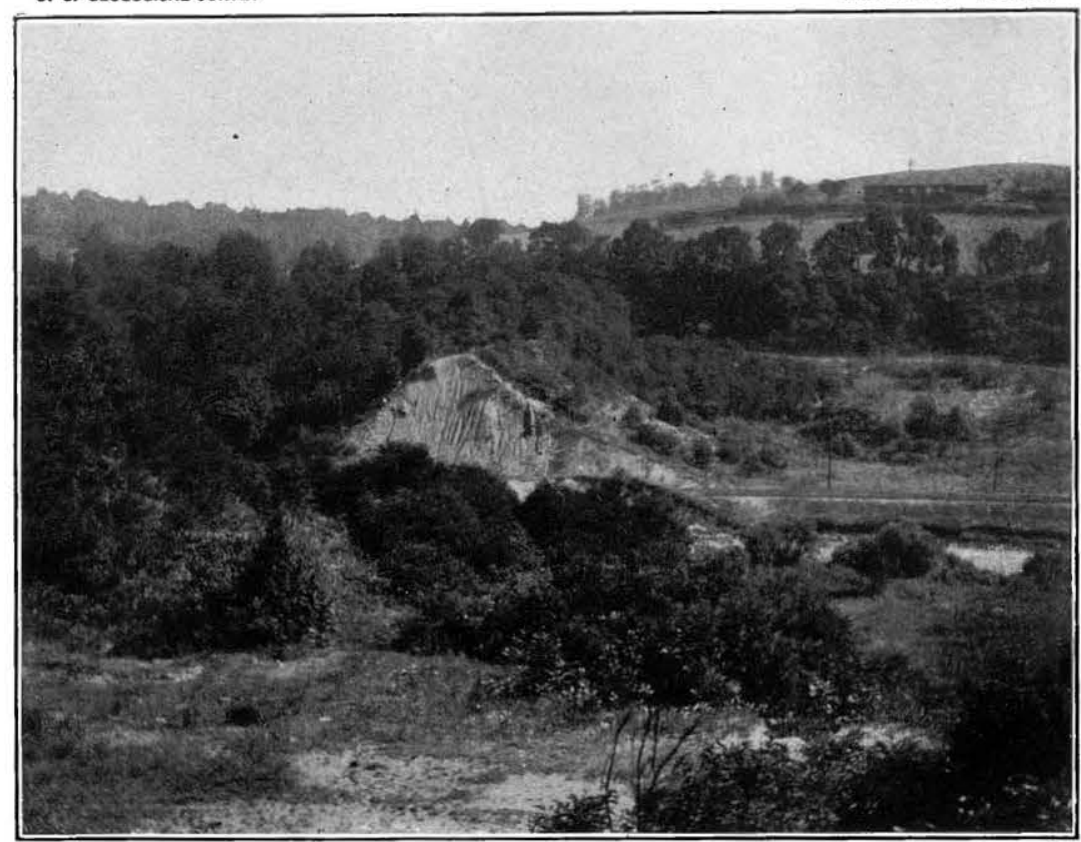

A. SOUTH FORK AND WASHED AWAY DAM.

The breaking of this dam caused the Johnstown flood of May 31, 1889.

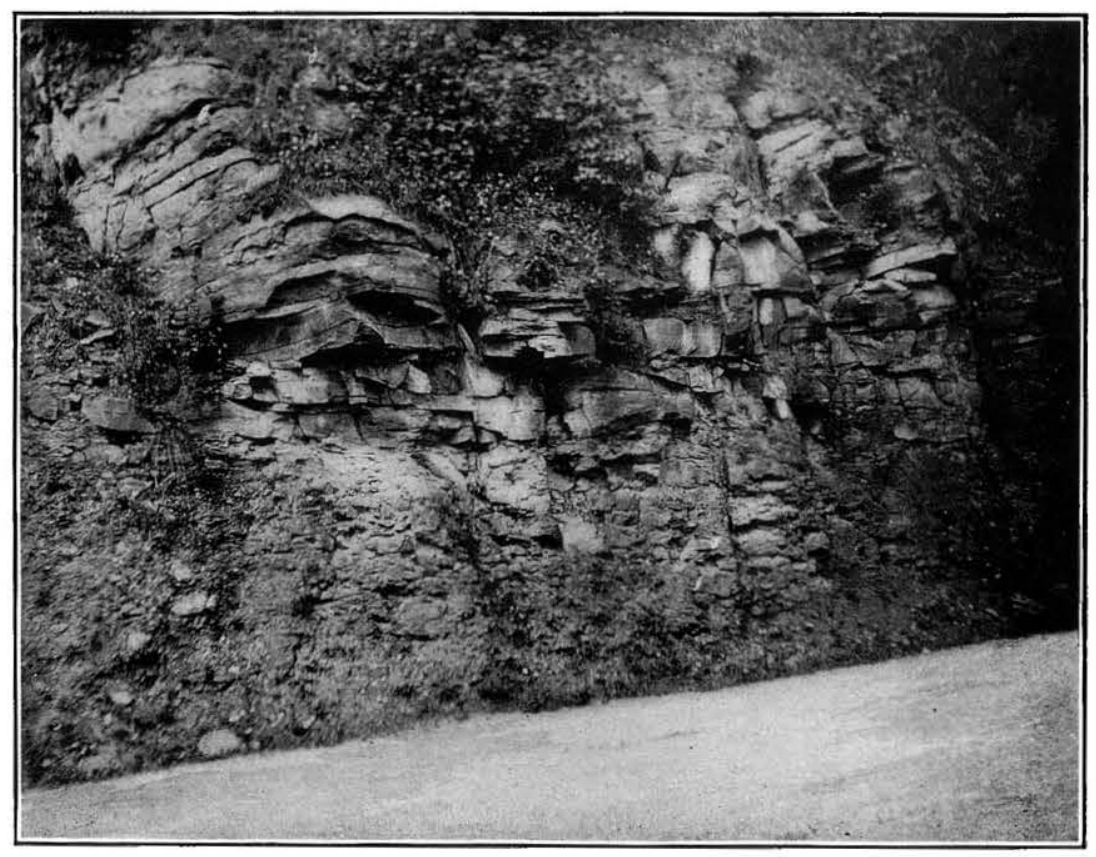

B. SANDSTONE NEAR BASE OF CONEMAUGH FORMATION NEAR JOHNSTOWN. 

Section of part of Mahoning sandstone member south of Johnstown, Pa.

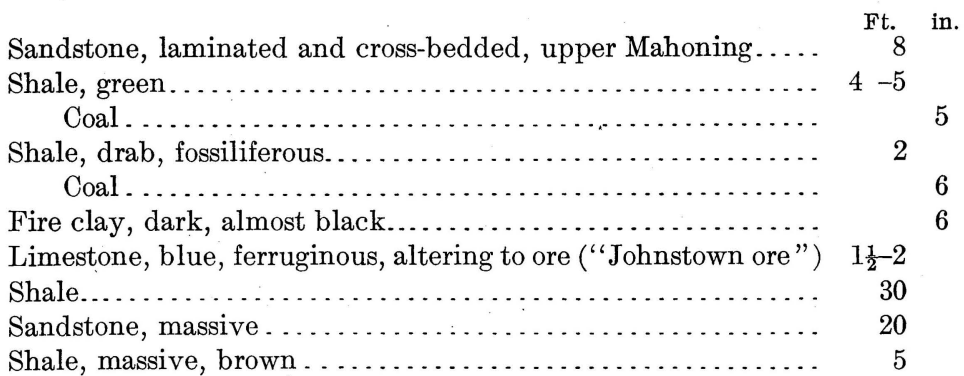

This section may be considered fairly typical for this immediate region. The upper sandstone, called upper Mahoning, is decidedly characteristic in appearance. It is fine grained, weathering into extremely thin slabs, and where seen to greatest advantage ranges in thickness up to 20 feet. The coal below it, exposed in the saddle in the road above the tunnel, is present in two benches with an interval of 2 feet between. This is probably the Mahoning coal. It is nowhere of workable thickness in this quadrangle.

The "Johnstown ore" underlies the Mahoning coal and is about 50 feet above the Upper Freeport coal. As a workable ore it has been found only in the center of the Johnstown Basin. It has been worked in the hills about the city, on Hinckston Run, at the west base of Laurel Ridge, and on Mill Creek. At present it is of no importance.

Flint clay. occurs in the shale interval lying above the lower Mahoning 'sandstone. It lies close to the top of the lower sandstone bed at an interval ranging from 50 to 80 feet above the Upper Freeport coal. The position of this flint clay is shown in the section in the hill east of Johnstown (p. 116). Its characteristics are described later (pp. 115-117).

The lower Mahoning sandstone outcrops in all the hills about Johnstown and has been quarried for building stone at many places. It is very massive, decidedly coarse grained, and micaceous. As a rule it ranges from 20 to 30 feet in thickness and is separated from the top of the Upper Freeport coal by 5 to 10 feet of dark-brown shale.

Near South Fork the base of the Conemaugh is well shown in a recent cut on the Pennsylvania Railroad near Ehrenfeld. A handleveled section obtained opposite the station is as follows:

Section of the base of Conemaugh formation at Ehrenfeld.

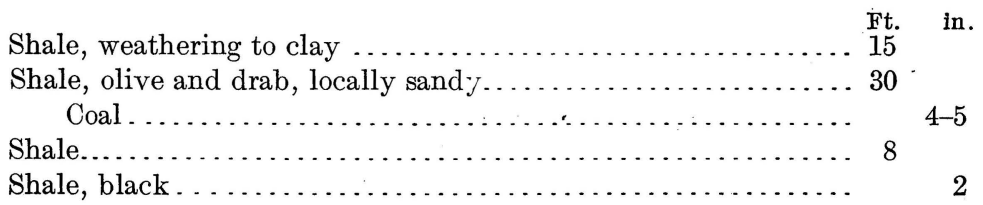




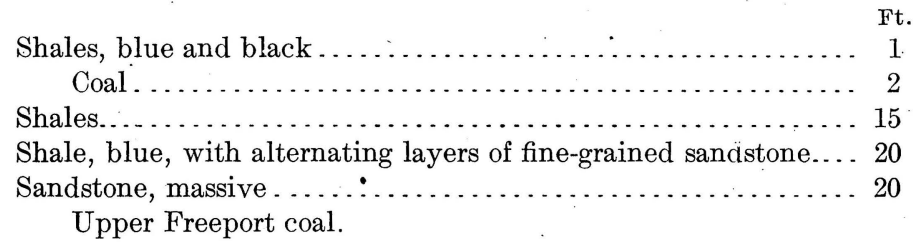

The Mahoning coal appears in this section, as in that south of Johnstown, in two benches at approximately the same distance above the top of the Upper Freeport coal. The lower bench is thiek enough to be worked, though so far as known no coal has ever been obtained from it. The lower Mahoning sandstone is fairly massive, but not so much so as in the hills nęar Johnstown.

In the hills bordering Blacklick Creek, near Wehrum, the Mahoning coal measures about a foot in thickness and is closely underlain by old ore benches, indicating the formerly extensive workings on the Johnstown iron-ore bed. The underlying flint clay is present north, west, and southwest of Wehrum in a position similar with respect to the lower Mahoning sandstone to that of the flint clay occurring above the same sandstone near Johnstown, and is thus to be correlated with that stratum. The lower Mahoning sandstone is persistent where it appears above drainage level in the Blacklick Creek district, and is fairly massive.

\section{ALLEGHENY FORMATION.}

GENERAL CHARACTER.

The Allegheny formation was originally known as the "Lower Productive Coal Measures." As may be inferred from that name, it is distinguished from the overlying formation by the presence of several workable coal beds. It is the most important formation in the Johnstown quadrangle, as in it are found all the workable coals of the area. The following section, compiled from the area about Johnstown and to the south, gives an idea of the general character of the formation in this quadrangle:

Section of Allegheny formation about Johnstown and to the south.

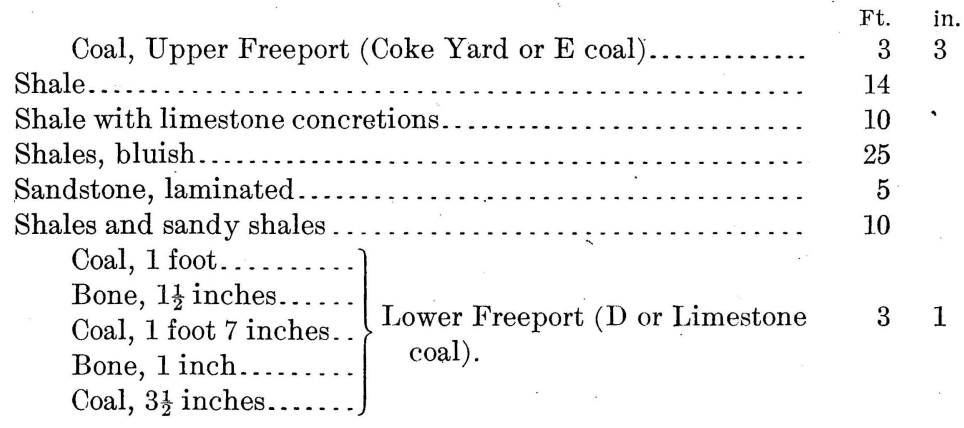




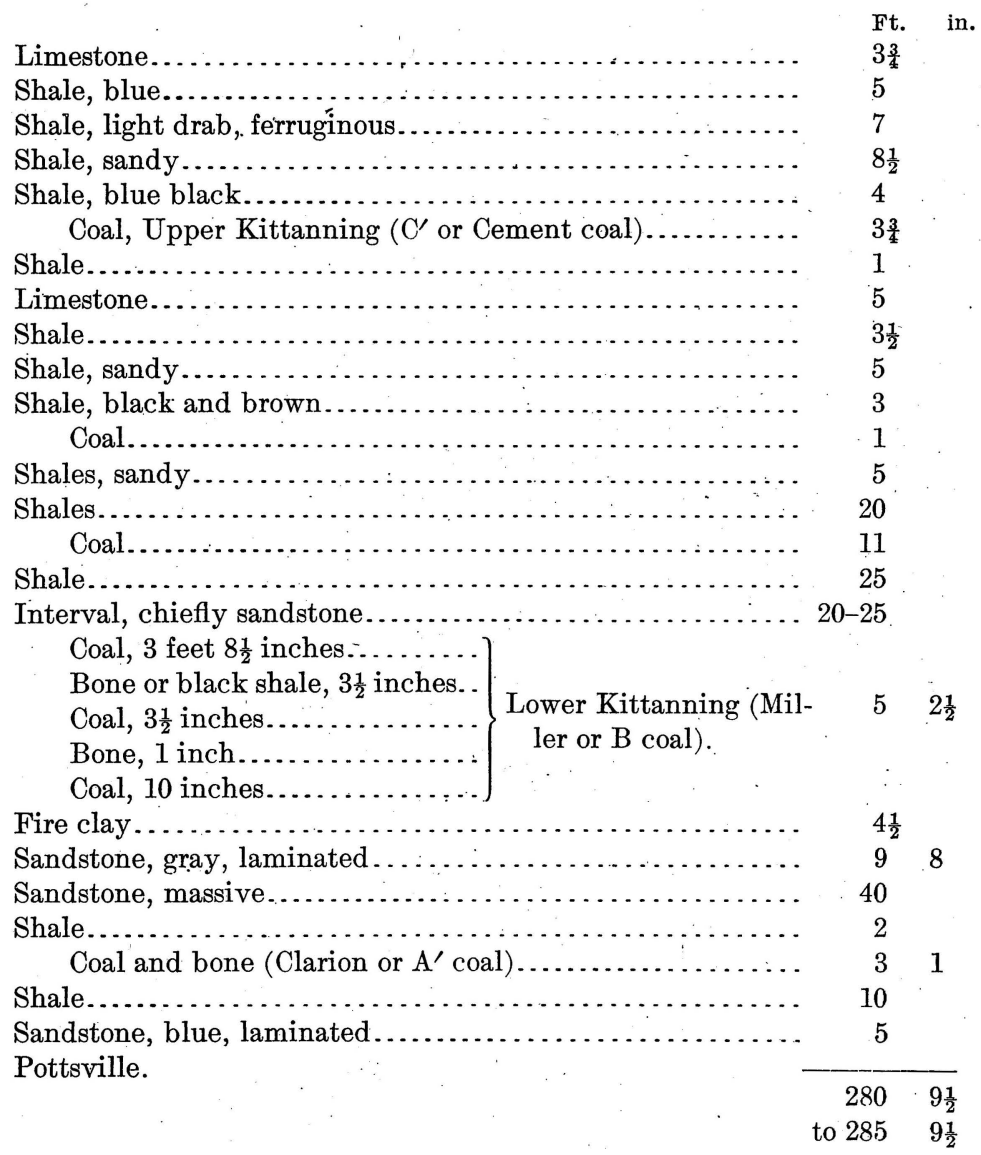

A section of the base of the Allegheny in which both the Brookville and Clarion coals show is as follows:

Section of lower part of Allegheny formation near A. J. Haws \& Sons' brick plant, Coopersdale.

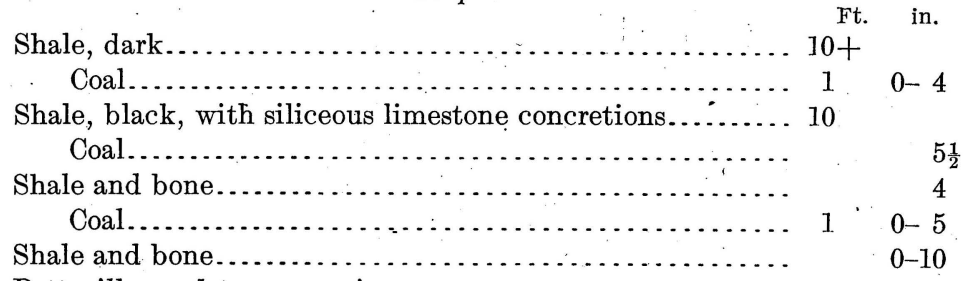

Pottsville sandstone, massive.

The thickness of the Allegheny ranges from 220 to 290 feet. At its top is the Upper Freeport coal; at its base the Brookville coal. The former occurs almost directly below the massive Mahoning sandstone; the latter rests directly on the top of the even more 


\section{MINERAL RESOURC.ES OF JOHNSTOWN, PA., AND VICINITY.}

massive Pottsville-circumstances which in this particular area are helpful in determining the boundaries of the formation.

The more characteristic members of the Allegheny formation occurring in the Johnstown quadrangle are the following:

Upper Freeport coal (E).

Upper Freeport limestone member.

Bolivar clay member.

Butler sandstone member.

Lower Freeport coal (D).

Lower Freeport limestone member.

Upper Kittanning coal ( $\left.\mathrm{C}^{\prime}\right)$.

Johnstown limestone member.

Coals between the Upper Kittanning and Lower Kittanning coals.

Lower Kittanning coal (B).

Lower Kittanning clay member.

Kittanning sandstone member.

Clarion coal.

Brookville coal.

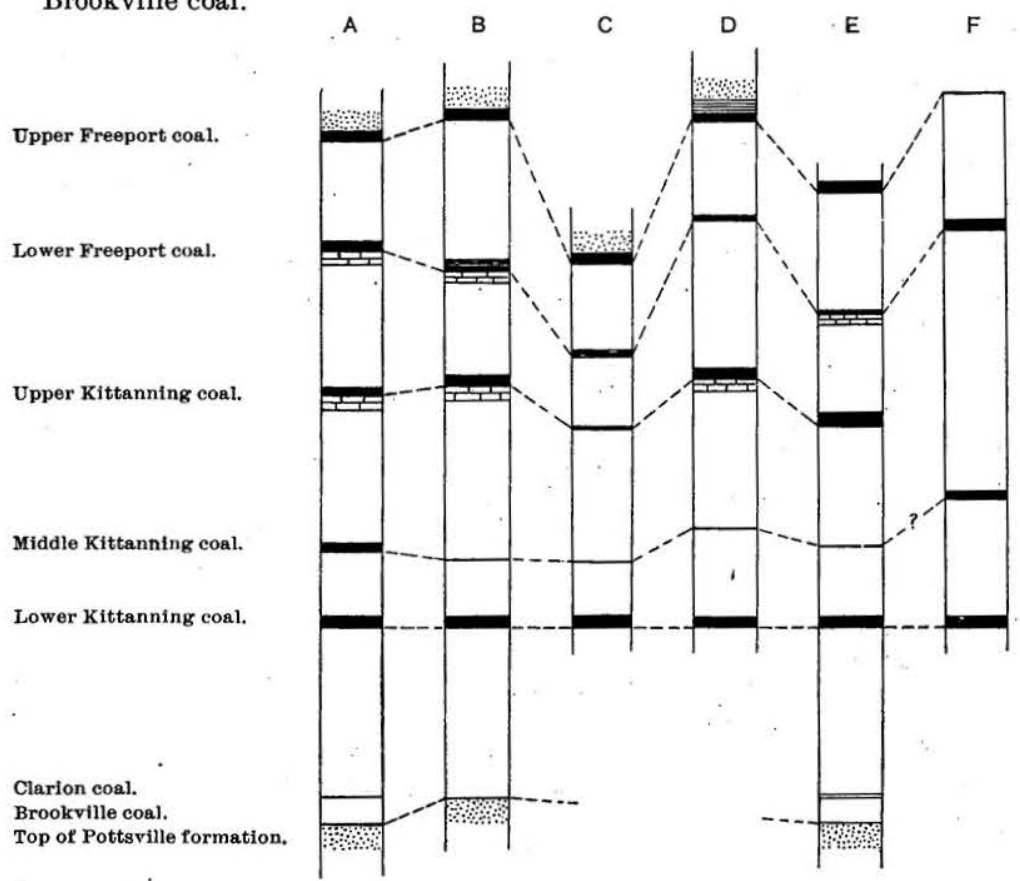

FIGURE 2.-Skeleton sections showing coals in the Allegheny formation. Vertical scale, 1 inch $=100$ feet. A, Compiled section near Coopersdale; B, compiled section on Peggys and Clapboard runs; C, section north of South Fork; D, section south of South Fork; E, compiled section near southern border of quadrangle; $\mathrm{F}$, section on Blacklick Creek.

The position of the coals with reference to one another in the different districts is well shown in figure 2. 


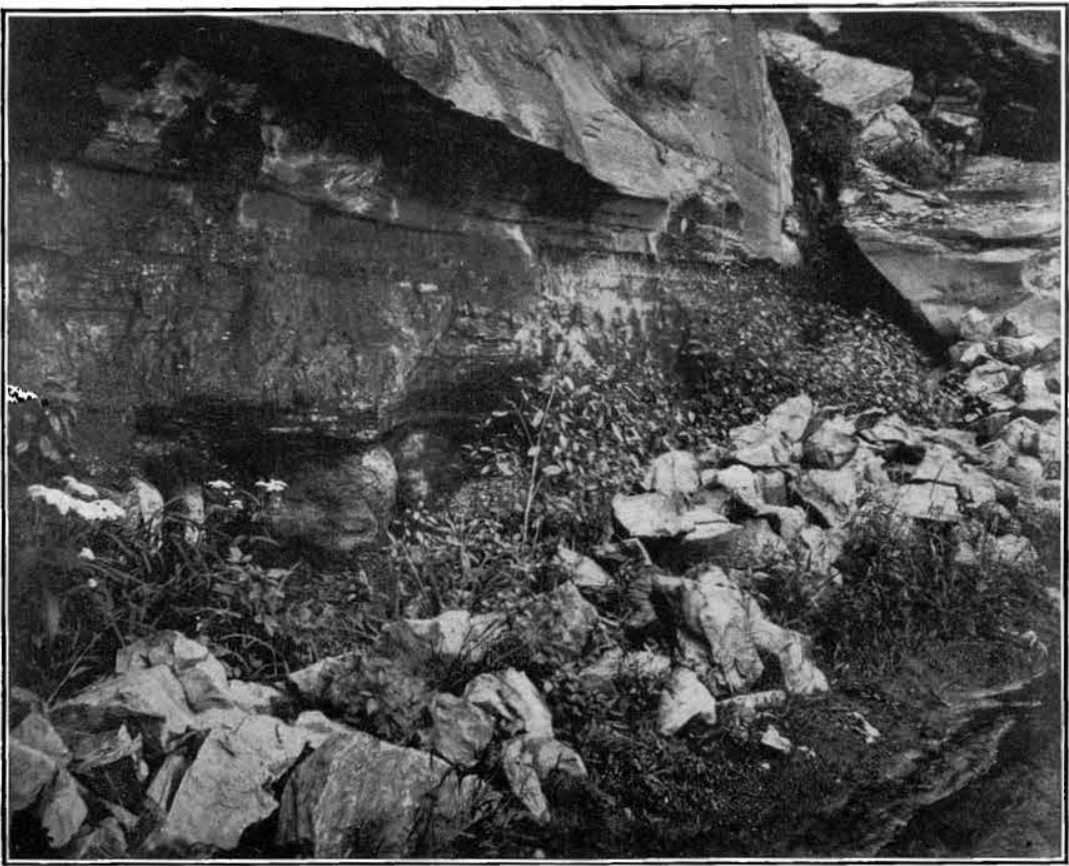

A. EXPOSURE OF LOWER FREEPORT COAL ON STONY CREEK, NEAR TROLLEY BRIDGE. The overlying sandstone is the Butler. The Lower Freeport limestone member shows below the coal.

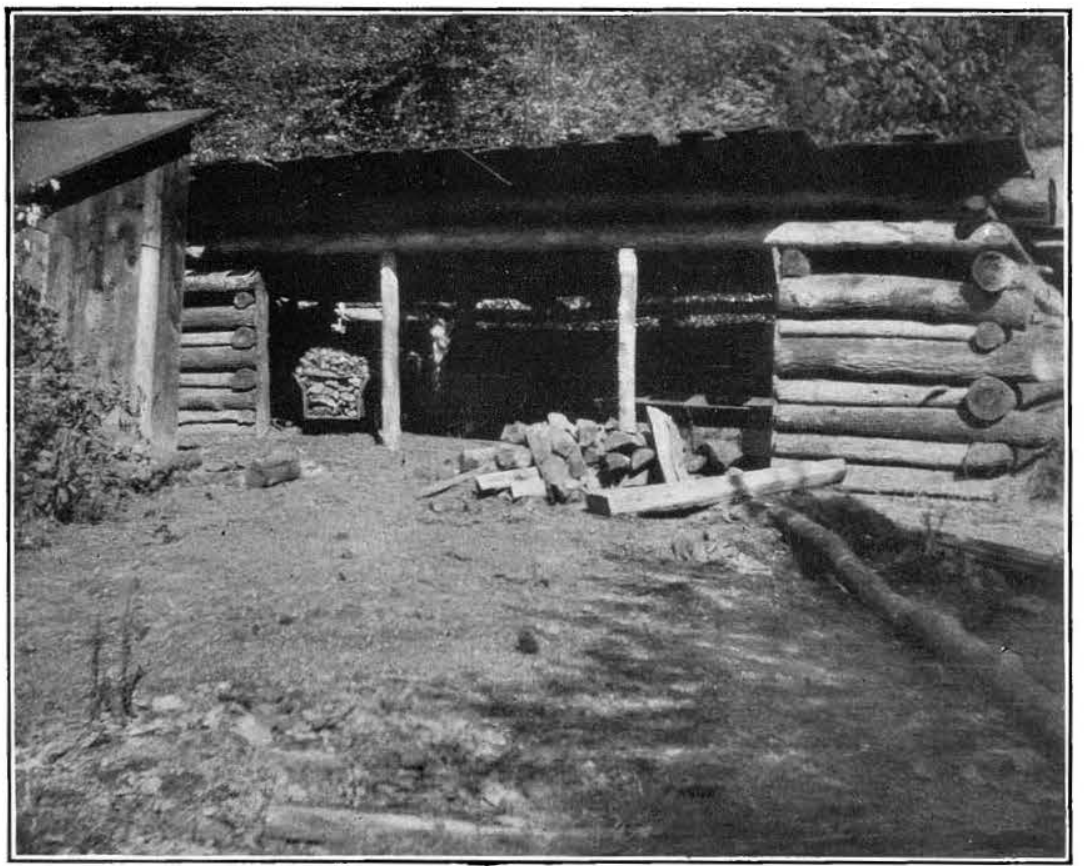

B. COUNTRY BANK OF THE BETTER CLASS ON THE UPPER KITTANNING COAL NEAR MINERAL POINT. 

DETAILED DESCRIPTION.

Upper Freeport coal.-The Upper Freeport coal lies at the top of the Allegheny formation, almost directly below the massive Mahoning sandstone member and from 220 to 290 feet above the top of the Pottsville formation, or, as it is locally called, the "Conglomerate Rock." It is known in the Johnstown district as the Upper Freeport or $\mathrm{E}$ bed but most commonly as the Coke Yard coal. In the South Fork district it is called the-Lemon or Four-foot coal. Its chemical and physical characteristics will be discussed in subsequent parts of this bulletin, as will be the case with the other workable coals.

Upper Freeport limestone member.-In the region near South Fork the Upper Freeport limestone appears in the section. A short distance east of Ehrenfeld it is well exposed in some recent excavations along the Pennsylvania Railroad, in which it ranges from $1 \frac{1}{2}$ to 3 feet in thickness. It is a gray limestone and very irregularly bedded. (See section, p. 65.)

Botivar clay member.-A flint clay lying a few feet below what is regarded as the Upper Freeport coal was seen at a few places in the valley of Mardis Run, near the northwestern edge of the quadrangle. This clay probably corresponds with the Bolivar fire clay of the region to the southwest. Two feet of clay was seen at one point on the outcrop, and the bed may possibly be thicker.

Butler sandstone member.-In some places on Stony Creek a very massive sandstone 20 feet thick was observed lying directly over the Lower Freeport or D coal. (See Pl. IV, A.) This corresponds in position to the Butler or "Upper Freeport" sandstone. It is very local in its development.

Lower Freeport coal.- The Lower Freeport or D coal is known about Johnstown as the Limestone bed from a 2 to 3 foot bed of limestone occurring within a foot of its base. In position it ranges from 45 to 70 feet below the Upper Freeport coal. (See Pl. IV, A.)

Lower Freeport limestone member.-The Lower Freeport limestone occurs either directly below or within a foot of the base of the Lower Freeport coal, the slight interval as a rule being filled with black shale. This limestone shows in Plate IV, $A$.

Upper Kittanning $\left(C^{\prime}\right)$ coal.-The next lower horizon of importance is the Upper Kittanning or $\mathrm{C}^{\prime}$ coal, known near Johnstown as the Cement coal. It is an important coal near Johnstown and Windber, and in fact is one of the most persistent and valuable coals in the quadrangle. It occurs from 80 to 105 feet below the Upper Freeport, though near South Fork this interval is less. Above the Upper Kittanning coal, near Johnstown and to the west on Dalton Run, some of the sections show one and some two small coals. These sections follow. 
Section of Upper Kittanning coal at mouth of Rolling Mill mine of Cambria Steel Company, Johnstown, Pa.

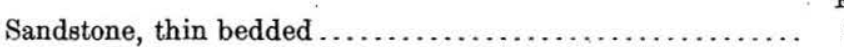

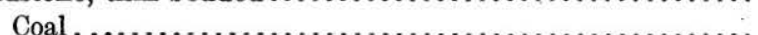

Sandstone, thin bedded and laminated................. 8

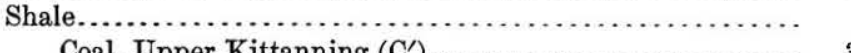

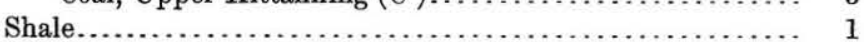

Limestone....................................... $4+$

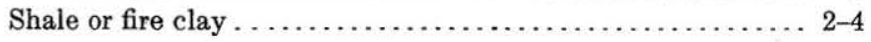

in.

$2-4$

6

Section of Upper Kittanning $\left(C^{\prime}\right)$ coal on Dalton Run.

Shale. Coal.

Ft. in.

4

Shale.

Coal.

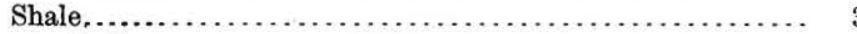

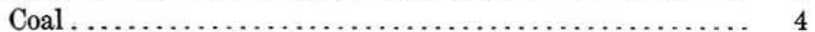

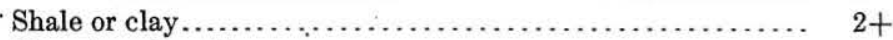

Limestone bowlders.

Johnstown limestone member.-About Johnstown the Upper Kittanning coal is underlain by a limestone which may prove suitable for the manufacture of cement. This cement bed is best developed along Stony Creek and may be seen to advantage in the cuts on the Baltimore and Ohio Railroad north of Kring, where it is 6 feet thick and is separated from the coal by 8 to 12 inches of shale. Along the spur track leading from the north end of the tunnel into the Valley Coal and Stone Company's mines it is also conspicuous but is slightly thinner. An analysis of this cement rock is given on page 128. It is shown in Plate VII, $A$ (p. 48).

Coals between the Upper and Lower Kittanning coals.-In several of the sections south of Johnstown a coal bed occurs from $17 \frac{1}{2}$ to 20 feet below the base of the Upper Kittanning coal. This coal is very thin, in most places measuring less than 6 inches. It may be seen in the bluffs near the Citizens Eighth Ward mine and in the cut on the Baltimore and Ohio Railroad north of Kring. At the latter place another coal $7 \frac{1}{2}$ inches thick appears in the section 13 feet below the upper thin coal and about 31 feet below the base of the Upper Kittanning bed. What is probably the upper of these two coals appears in many of the drill records from the Wilmore Basin, and both are persistent in the section along the main line of the Pennsylvania Railroad east of East Conemaugh. In the latter region, however, the lower coal, which it is thought must be the representative of the Middle Kittanning (C) coal, lies 45 to 50 feet below the base of the Upper Kittanning-a distance greater than at Kring. Near the brick plant of A. J. Haws \& Sons (Limited), at Coopersdale, what is tentatively regarded as the Middle Kittanning occurs 25 feet above the Lower Kittanning bed. 
Lower Kittanning coal.-The next lowercoal-theLower Kittanning, Miller, White Ash, or B coal-is the most persistent and valuable bed in the area. It usually lies approximately 145 to 200 feet below the Upper Freeport coal and from about 65 to 100 feet above the top of the Pottsville.

Lower Kittanning clay member.-The Lower Kittanning clay is the most valuable plastic clay in the area. It usually underlies the lower bench of the Lower Kittanning coal, from which it may be separated by a few inches of shale. In the absence of the lower bench of coal it sometimes occurs below the main coal itself, being separated from it by 3 to 4 inches of bone or shale. (See, further, pp. 117-118, 123.)

Kittanning sandstone member.-On the Baltimore and Ohio Railroad, between Foustwell and the mouth of Paint Creek, on the west flank of the Ebensburg anticline, the Pottsville and the beds below the Lower Kittanning coal are well exposed. Near the water tank and culvert nearly a mile east of the bridge over Stony Creek the following section was measured:

Section of the lower part of the Allegheny formation, east of Foustwell.

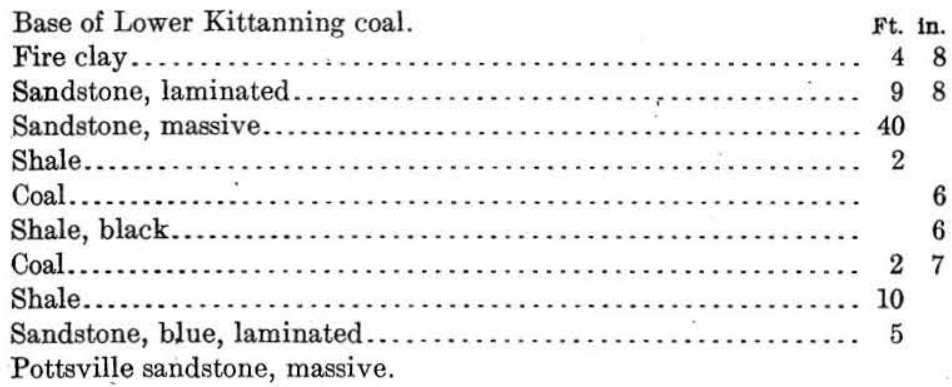

Brookville and Clarion coals.-Between the Lower Kittanning coal and the top of the Pottsville formation are found either one or two coals. The coal noted in the preceding section is one of these, possibly the upper or Clarion bed; where the section was taken it is of workable thickness. Both coals appear at the roadside near A. J. Haws \& Sons' brick plant, west of Coopersdale. (For section, see p. 23.) The lower coal, consisting of two benches, is the Brookville; the higher is regarded as the Clarion. Representatives of these lower coals are found near Twin Rocks.

\section{POTTSVILLE FORMATION:}

The Pottsville, where most plainly developed in the Johnstown quadrangle, consists of three members-an upper and a lower sandstone, known respectively as the Homewood and Connoquenessing sandstone members, and an intervening shale (containing a coal bed), known as the Mercer shale member. With these is associated an important flint clay. 
A section of the Pottsville along Stony Creek, in part off the southern edge of the quadrangle, is as follows:

Section of Pottsville formation in and near Johnstown quadrangle.

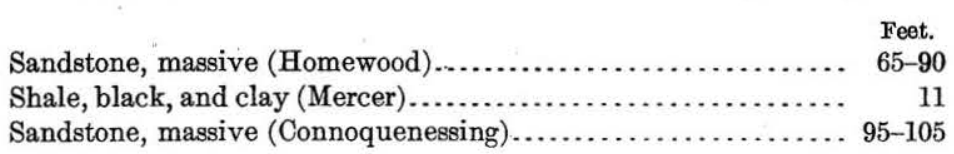

This gives a total thickness to the Pottsville of about 170 feet. Between South Fork and Mineral Point the thickness of the Homewood member, where it could best be observed, is only about 35 feet, indicating a thinning to the east; the thickness of the whole formation, however, remains at about 170 feet. In the South Fork district the Mercer interval contains a valuable flint clay.

The Pottsville is not always devoid of coal, as the section given above might indicate. South of Kring the Mercer contains a coal bed whose section is given on page 61. At the B. H. Campbell shale quarry, on the Mercer (p. 119), coal is also present.

The sandstones of the Pottsville are massive and coarse grained but rarely conglomeratic. They make very large sandstone débris, and the country underlain by the Pottsville is usually wilderness.

\section{MISSISSIPPIAN SERIES. \\ MAUCH CHUNK SHALE.}

Evidences of an unconformity at the top of the Mauch Chunk are to be seen in the Johnstown quadrangle. The Mauch Chunk is well exposed along the flanks of the Ebensburg anticlinal axis on Stony Creek, near the bridge at the mouth of Paint Creek, and also south of the quadrangle. It is also well shown at the viaduct along the flanks of the Viaduct or Ebensburg anticline (Pl. V, $A$ ), farther west in the gorge of Conemaugh River, and on the sides of Laurel Ridge, where it is brought above drainage level by the Laurel Ridge anticline. The upper 50 feet of this formation is exposed in the valley of South Branch of Blacklick Creek, near Twin Rocks.

A section of the upper part of the formation, obtained on Stony Creek about a mile above the mouth of Paint Creek, is as follows:

Section of upper two members of Mauch Chunk shale near mouth of Paint Creek.

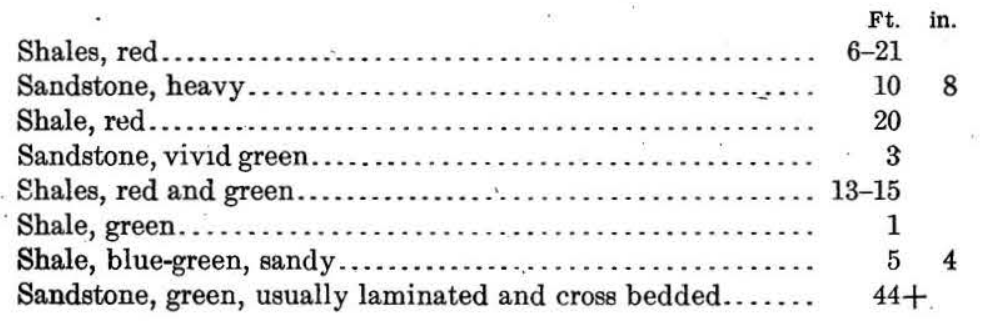




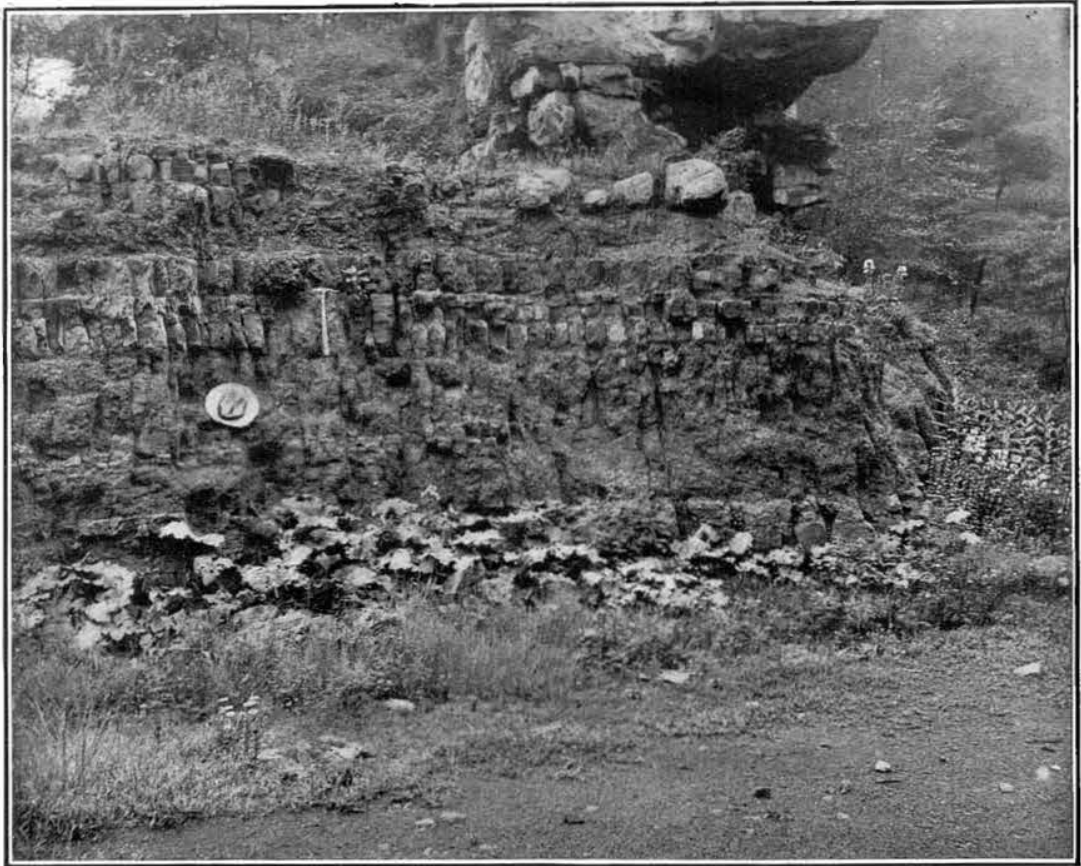

A. TYPICAL EXPOSURE OF MAUCH CHUNK SHALE AT THE VIADUCT BETWEEN SOUTH FORK AND MINERAL POINT.

Note the alternating thin layers of sandstone and shale and the vertical jointing.

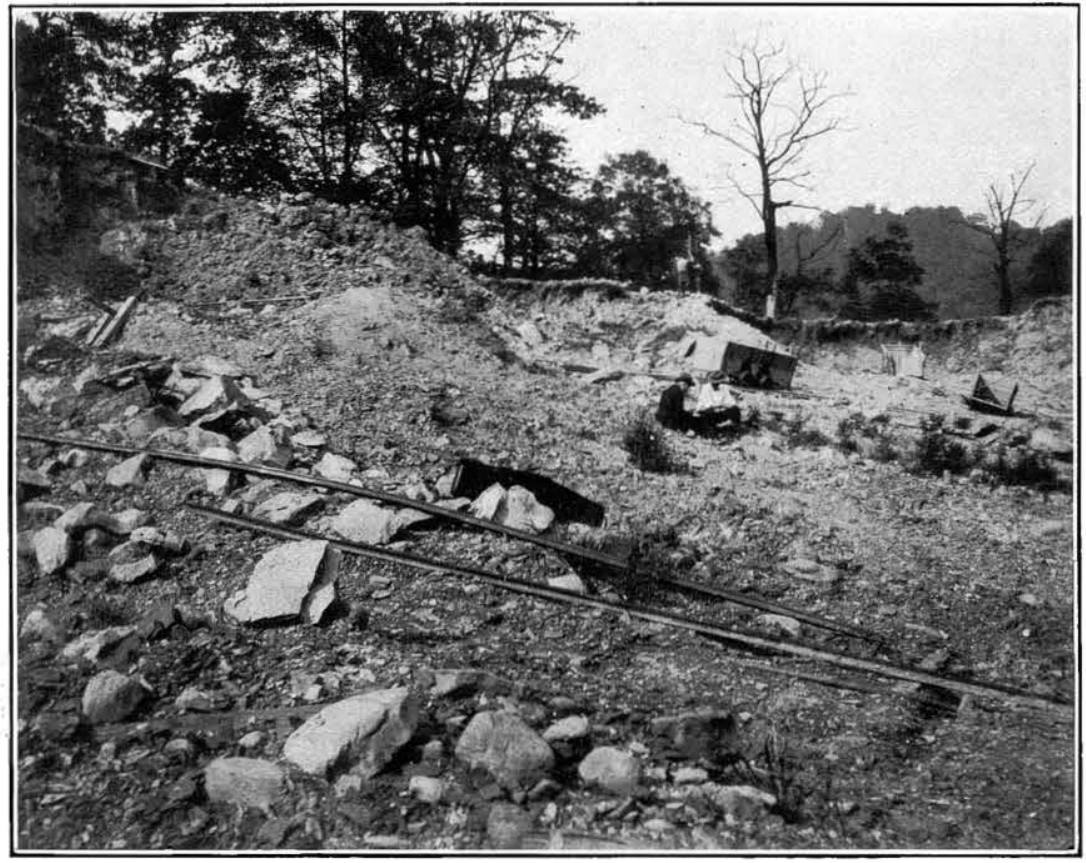

B. SHALE QUARRY OF B. H. CAMPBELL AT THE MERCER HORIZON NORTH OF SHERIDAN.

The rounded bowiders in the foreground are probably of Pleistocene age. 



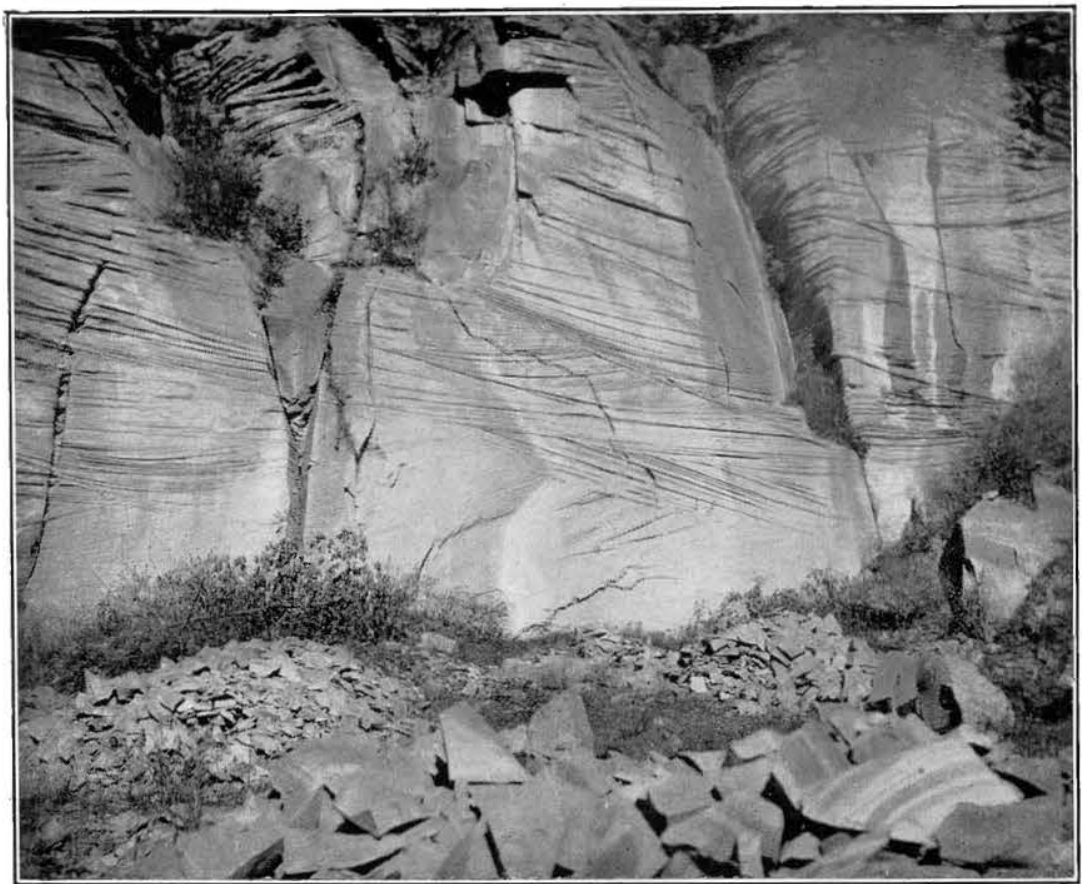

A. DETAILED STRUCTURE OF LOYALHANNA LIMESTONE AT THE TOP OF THE POCONO FORMATION, EAST OF MINERAL POINT.

Weathering has brought out the cross-bedding of the rock.

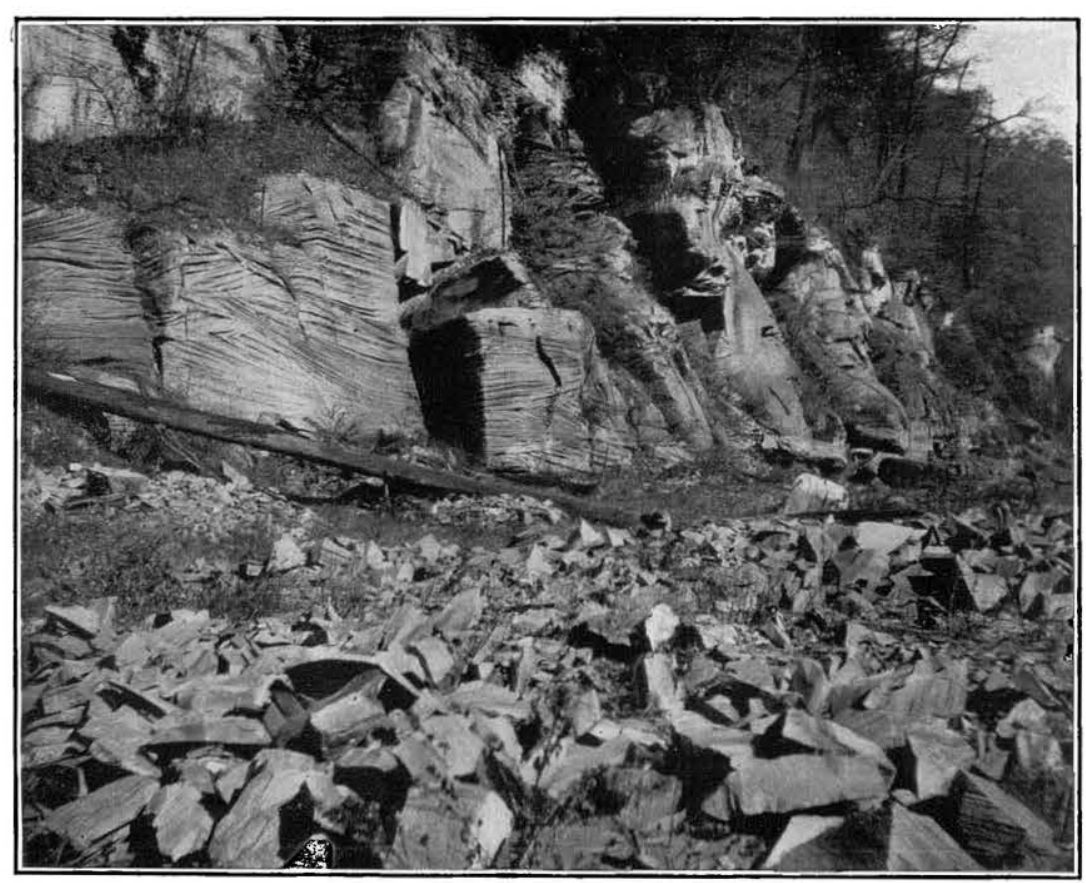

B. LOYALHANNA LIMESTONE, TOP MEMBER OF POCONO FORMATION, AT SUMMIT OF EBENS. BURG (VIADUCT) ANTICLINE, MINERAL POINT. 

Near the viaduct the lower green laminated and cross-bedded sandstone member given in the section appears, dividing, as it were, the Mauch Chunk into an upper and lower shaly member. It may represent the Greenbrier limestone in this region. This sandstone at the viaduct was measured in its entirety and was found to be 42 feet thick. The lower shale division at the viaduct is 40 feet, giving to the members of the Mauch Chunk the following thicknesses:

Section of Mauch Chunk shale at the viaduct.

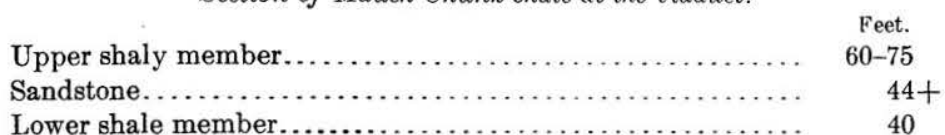

Thus the Mauch Chunk in this quadrangle may be considered approximately 160 feet thick.

\section{POCONO FORMATION.}

The upper part of the Pocono shows in the bed of Conemaugh River between the viaduct and Mineral Point. It is made up of the Loyalhanna limestone member, about 45 feet of which is here exposed. (See Pl. VI, $A$ and $B$.) The entire formation is above drainage level in the gorge of Conemaugh River west of Johnstown. It is brought above water level by the Laurel Ridge anticline and covers part of the ridge both south and north of the river. Though it is not exposed so as to be measured in detail, the barometer indicated from the top of the red Catskill beds to the red shales of the Mauch Chunk overlying the Loyalhanna limestone a thickness of 1,085 feet, which it is believed closely approximates the thickness of this formation in the region. This is slightly greater than the figures obtained by Charles Butts and the writer ${ }^{a}$ on the Allegheny Front. There is no reason to suppose that the Pocono here differs much from that on the Allegheny Mountain east of Bennington.

\section{DEVONIAN SYSTEM.}

CATSKILL FORMATION.

But 400 feet of Devonian rocks are exposed in the Johnstown quadrangle, and these occur at the top of the Catskill, in the gorge of Conemaugh River where it is crossed by the Laurel Ridge anticlinal axis. The Catskill beds are prevailingly red and green shales and red sandstones and color the soil a distinct red. The upper part of the formation was measured by the writer as follows: 
Section of upper portion of Catskill formation on Conemaugh River.

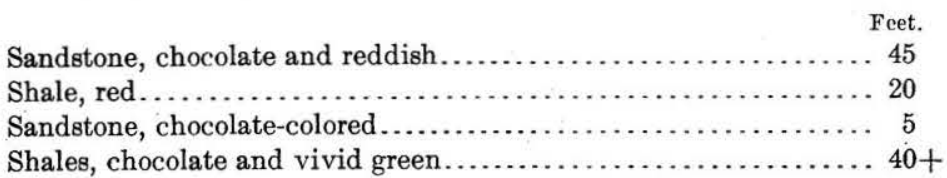

STRUCTURE.

MODE OF REPRESENTATION.

The inclination of the beds to a horizontal plane, or the dip, as it is commonly called, is measured in the field by means of a clinometer where the inclination is great enough to permit it. .In but few localities in the Johnstown quadrangle, however, are the dips sufficient to allow this mode of measurement. Where it is not applicable continuous road sections are run and the beds are correlated from hillside to hillside. When the elevation above mean sea level of a sandstone, coal, or limestone on one hill and its elevation a mile or so away have been found, the rise or fall of this particular bed in feet per mile is at once obtained. By connecting points of equal elevation on any selected bed the contour lines for that bed are drawn. On the map, Plate I, the contour interval is 50 feet and all points on the plane selected (the base of the Lower Kittanning or B coal) that are multiples of 50 are connected by light-brown lines.

The base of the Lower Kittanning coal was selected as the bed on which to draw structure contours in the Johnstown quadrangle because this is commercially the most important coal and the most persistent. Moreover, its relations to the beds both above and below it are fairly well known.

To draw contours on the bed where it is above drainage level and is worked is easy, for it is necessary simply to obtain its elevation from point to point where it outcrops and then to connecting points of equal elevation. But where the coal fails to appear above drainage level other means of determining its elevation have to be employed, and its distance below other known beds that do appear must be used as a basis for calculation, it being assumed, of course, that this distance is constant within the areas where this method is employed. Conversely, where the dips are so great as to carry the horizon of the coal above the hilltops its interval above known beds must be used. When the latter two methods are employed in contouring great precision is not obtainable, as intervals are subject to variation in any region and are known to vary greatly within comparatively short distances in the Johnstown quadrangle. Furthermore, most of the elevations in this work are obtained by means of the aneroid barometer, which, as is well known, is liable to sudden variations and has to be constantly checked against spiritleveled elevations. 
The structure contours not only show the generalized surface formed by the Lower Kittanning coal but less precisely the lay of the underlying and overlying beds. The contour interval chosen is 50 feet and the limit of error may be considered a contour interval, but where the beds vary in thickness it may be more than this. This mode of representing the structure makes it possible to estimate approximately the elevation of the top of the Lower Kittanning coal where it is below the surface at a given point, and hence to find its depth below the surface at that point; furthermore, if the intervals of other coals either above or below the Lower Kittanning are known, their depth at any particular point may be readily computed.

\section{STRUCTURE IN THE JOHNSTOWN QUADRANGLE.}

GENERAL STATEMENT.

The beds described under the heading "Stratigraphy," (pp. 14-30) are involved in a series of parallel folds having a general northeastsouthwest trend and extending completely across the area in a series

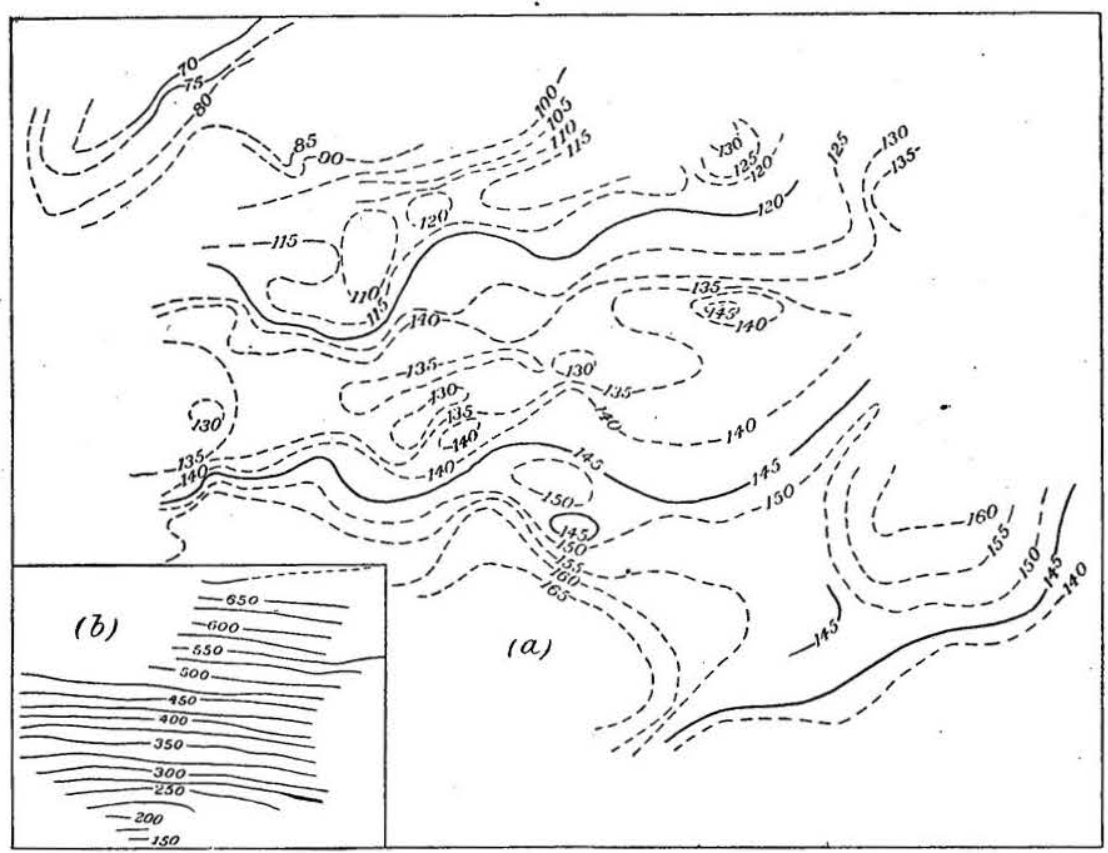

FIGURE 3.-Sketch showing ( $a$ ) the great irregularity in detail of the structure in some parts of the Johnstown quadrangle and $(b)$ the marked regularity in detail in other parts. In $b$ the 5 -foot contour lines are omitted to avoid crowding, but were they inserted the regularity would appear almost as pronounced.

of waves from the southeast to the northwest part of the quadrangle. The structure as worked out differs in some particulars from that described by the Second Survey of Pennsylvania, the most notable difference perhaps being in the offset of the Johnstown Basin to the 
east near Johnstown (Pl. I). In the map of the Second Survey the axis of the Johnstown syncline or basin is represented as being west of the South Fork of Bens Creek; it is believed that it really lies farther to the east.

Viewed broadly, the structure is very regular in the Johnstown quadrangle, as will be seen from the structural contour map (Pl. I). In detail it may be decidedly irregular. (See fig. 3.)

The structural features in the Johnstown quadrangle, beginning in the southeast corner and proceeding to the northwest, are-

Wilmore syncline.

Viaduct or Ebensburg anticline.

Johnstown syncline.

Laurel Ridge anticline.

Westover or Barnesboro syncline.

In the reports of the Second Geological Survey of Pennsylvania the Wilmore and Johnstown basins were designated subbasins and were considered to constitute part of the first bituminous coal basin. The Viaduct anticline was called a subaxis and the Laurel Ridge anticline was designated the first grand axis of the bituminous coal regions. ${ }^{a}$ D'Invilliers ${ }^{b}$ somewhat changed the usage, as he speaks of the first and second basins, referring to the Wilmore and Johnstown basins, respectively. The terms syncline and basin or trough are of course synonymous, as are also the terms anticline and arch.

\section{DETAILED DESCRIPTION.}

Wilmore syncline.-The Wilmore Basin or syncline is so called from the town of Wilmore, situated on the Pennsylvania Railroad a short distance east of Summerhill, in the Ebensburg quadrangle. It is a comparatively long and narrow synclinal trough parallel with and west of the Allegheny Front. The position of the axis of the basin is definitely fixed near the town of Wilmore by the opposing dips of the rocks along the old track of the Pennsylvania Railroad. As indicated on Plate I, the axis enters the Johnstown quadrangle northeist of the old reservoir site on South Fork of Conemaugh River and continues southeast, passing near the town of Elton. It leaves the quadrangle in a line almost coincident with the South Fork branch of the Pennsylvania Railroad. On the southeast side of this axis the beds dip northwest, and on the northwest side the beds dip southeast. In the quadrangle all the beds along the axis dip northeast, as the axis plunges in that direction. The rise of the beds to the southwest is rapid, amounting to 900 feet in a distance of 16 or 17 miles, so that the Lower Kittanning coal, which is between 800 and 900 feet above the sea and hence far below drainage level in the center of the basin,

a Second Geol. Survey Pennsylvania, Rept. H2, pp. xxix, 25, 26.

b Summary Final Rept. Geol. Survey Pennnsylvania, 1895, p. 2219. 
outcrops at an elevation of about 1,700 feet at the mines about Windber.

Viaduct anticline.-The Viaduct or Ebensburg anticline is the next structural feature to the west. Its axis has a general northeastsouthwest direction, but swerves slightly to the southeast and then again to the southwest in the part of the quadrangle south of Conemaugh River. This offset, however, is not at all marked.

The Lower Kittanning coal and associated beds, so deeply buried in the center of the Wilmore Basin, rise rapidly and with great regularity to the west and outcrop in the valley of Conemaugh River at South Fork. From its deepest point in the Wilmore syncline the coal rises more than 1,000 feet to its highest point on the summit of the Viaduct or Ebensburg anticline. The lowest bed brought above drainage level by this rise is the top member of the Pocono formation (the Loyalhanna limestone member), which outcrops along the summit of the arch, between the viaduct and Mineral Point. (See Pl. VI, $A$ and $B$.)

Johnstown Basin.-The Johnstown Basin or syncline, which is the next structural feature to the west, comprises the area between the Viaduct and Laurel Ridge anticlinal axes. It is really made up of two basins in this quadrangle, one in Cambria and one in Somerset County. It has a general northeast-southwest course but is sharply offset to the east in the vicinity of Johnstown. (See PI. I.) The axis in Somerset County trends in the usual northeast-southwest course. The dip of the beds on the east side of the basin is comparatively gentle, the fall being approximately 900 feet in 9 miles, or at the rate of 100 feet per mile from the summit of the Viaduct anticline at the viaduct to the deepest part of the basin north of Conemaugh River. In the southern part of the quadrangle the corresponding drop is only 700 feet. On the west side of the basin the rise of the beds to the Laurel Ridge axis is sharp-between 2,000 and 2,100 feet in a distance of 9 miles along Conemaugh River-producing the maximum dips in the quadrangle. In addition to their inclination from the northwest and southeast to the center of the basin, the beds north of Conemaugh River dip gently to the northeast. The Johnstown synclinal axis and the Ebensburg anticlinal axis approach each other near the northeast corner of the quadrangle.

Laurel Ridge anticline.-The Laurel Ridge anticline is the major structural feature in the Johnstown quadrangle, and, as stated on page 32, it is the "first grand axis" as described by the Second Geological Survey of Pennsylvania. It crosses Conemaugh River about midway between Conemaugh Furnace and Coopersdale and passes to the northeast, crossing South Branch of Blacklick Creek a little over a mile southeast of Twin Rocks. Where the axis of the $69516^{\circ}-$ Bull. $447-11-3$ 
fold crosses the valley of Conemaugh River the lowest beds in the quadrangle - the red shales and sandstones of the Catskill formation, aggregating 400 feet or more above drainage level-are exposed. The fold pitches sharply to the northeast, and the Pocono formation, which caps the hills where the axis crosses Conemaugh River, is below drainage level where it crosses South Branch of Blacklick Creek near Twin Rocks, dropping in this distance at least 1,000 fert. As stated in the description of the Johnstown Basin, the beds along the eastern flank of the Laurel Ridge anticline rise between 2,000 and 2,100 feet in a distance of 9 miles. The fall in the beds west of the anticlinal axis to the Barnesboro or Westover Basin is at about the same rate. The anticline is therefore symmetrical.

No beds of coal are present at the summit of the ridge and none occur below its surface until Blacklick Creek is approached. The coals have, so to speak, been carried out into the air by the rise in the beds on either side of the anticlinal axis.

Barnesboro or Westover syncline.-The basin west of the Laurel Ridge anticline is termed the Westover Basin in the Pennsylvania Geological Survey reports. More recently it has been called the Barnesboro Basin by members of the United States Geological Survey. $^{a}$ The axis of the basin enters the Johnstown quadrangle near the line between Cambria and Indiana counties, passes through or very near Wehrum, and leaves the quadrangle as indicated on Plate I. From the axis of this basin the beds rise gently to the axis of the Nolo anticline, which just cuts the northwest corner of the quadrangle.

Minor structures.-Besides the principal folds, there are many minor folds in the rocks of the quadrangle. A small arch or anticline is exposed along Little Conemaugh River about a mile east of Conemaugh station. From this point westward to the Johnstown station there are many minor fluctuations, all exposed along the main line of the Pennsylvania Railroad. Between Millville and Coopersdale there is a distinct anticline. Thus it appears that the main broad Johnstown syncline has been subjected to many minor plicitions. It has been thought by some mining men that to these lesser folds about Franklin and along Clapboard Run is due the so-called faulting which the coal exhibits in this region. The erratic behavior of the Lower Kittanning coal in this locality may possibly be due in part to this cause, but the irregularities seen by the writer are not faults as this term is used in the geologic sense, but are rather broad rolls which seem to have squeezed out the coal. In some places the conditions during sedimentation were such that coal was not deposited or, if deposited, was afterward removed.

a Campbell, M. R., and Clapp, F. G., in an unpublished manuscript relating to the Barnesboro quad. rangle, which lies north of the Johnstown quadrangle. 


\section{MINERAL RESOURCES.}

\section{INTRODUCTION.}

The mineral resources of the Johnstown quadrangle are coal, flint and plastic clay, shales, limestone and cement material, building stone, glass sand, and iron ore. Because of the great importance of coal and clay they will be treated (1) in a broad way for the sake of the general reader who may be interested in the area as a whole but not in any particular portion of it, and (2) in detail by districts. The remaining resources-limestone and cement material, building stone, glass sand, and iron ore-will be treated as a whole, as their description by districts would involve needless repetition.

COAL.

GENERAL DESCRIPTION.

\section{UPPER FREEPORT COAL.}

The highest important coal in the Johnstown quadrangle is known as the Upper Freeport. It is used as a domestic and steam fuel about Johnstown and South Fork and supplies some of the brick plants at Johnstown. It gives satisfactory results, particularly when used in locomotives. It is not coked in this quadrangle, though at Cresson, Gallitzin, and Bennington it gives satisfactory results in beehive ovens. In the by-product ovens of the Cambria Steel Company at Franklin, near Johnstown, it was found to be unsuitable owing to expansion, which quickly ruined the ovens and made it very difficult to force out the charge after it was coked. The analyses of this coal as given on page 40 show it to be a high-carbon coal with very low moisture content. The ash, especially in the Johnstown Basin, is high; its sulphur content, ranging from 2 to $2 \frac{1}{2}$ per cent, is also rather high.

LOWER FREEPORT COAL.

The Lower Freeport or D coal is of workable thickness about Johnstown, and, though not exploited at present, it will probably become one of the important coals of the Johnstown district. Its percentage of carbon is high.

\section{UPPER KITTANNING ( $\left.\mathbf{c}^{\prime}\right)$ COAL.}

The Upper Kittanning or $\mathrm{C}^{\prime}$ coal is one of the most valuable beds about Johnstown and its suburbs, where it is known as the Cement bed. To the south, about Windber, prospecting has shown it to be even thicker than about Johnstown. As a steaming coal it is probably equal if not superior to any other coal in the Johnstown 
Basin, and the recent demand for it has been greater than the supply. The six analyses (p. 40) show a high-carbon coal with correspondingly low volatile matter. The moisture is low, but the ash and sulphur are rather high. The coal mined from this bed at Franklin mine No. 1 of the Cambria Steel Company is washed and coked at the Franklin plant. It makes a coke of good grade, but owing to its low volatile matter it is not considered so well adapted for beehive ovens as some of the richer gas coals of the districts farther west. In view of the cost of shipping coke from the region about Connellsville and Pittsburg, it is cheaper to wash and coke this coal on the ground. The coal is worked also in a small way near South Fork.

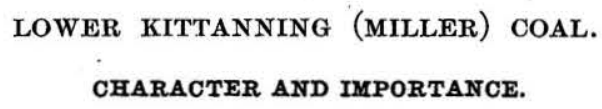

The next lower coal of importance in this area is the Lower Kittanning or B coal, also widely known as the Miller seam. This is the most persistent of the valuable coals of the area. From the analyses on pages 40-42 it will be seen that its fixed carbon ranges from 68 per cent in sample No. 24, collected at Wehrum, Indiana County, to more than 78 per cent in samples collected at South Fork. Its volatile matter ranges from 14 to 19 per cent. Its moisture is low; only a few analyses show more than 3 per cent and in none of them does it exceed 4 per cent. The ash and sulphur exhibit considerable variation, as might naturally be expected in view of the wide extent of the territory from which the samples were collected. The samples from South Fork have the lowest content both in sulphur and ash and show the excellent character of the Lower Kittanning bed in this part of the Wilmore Basin. As a steam coal it ranks among the very best in western Pennsylvania, the coal mined about South Fork probably equaling any other steam coal in this part of the State. As bearing on this point the following table has been prepared, showing its position among the 120-odd coals tested at the fuel-testing plant of the United States Geological Survey at St. Louis, Mo., since the summer of $1904 .^{a}$ The column recording the number of pounds of water evaporated by 1 pound of dry coal from and at a temperature of $212^{\circ} \mathrm{F}$. gives the comparative results of the coals tested so far as these relate to their commercial value. 
Chemical composition and steaming values of typical Appalachian coals.

\begin{tabular}{|c|c|c|c|c|c|c|c|}
\hline \multirow[b]{2}{*}{ : } & \multirow{2}{*}{$\begin{array}{c}\text { Num- } \\
\text { ber of } \\
\text { tests } \\
\text { made. }\end{array}$} & \multicolumn{5}{|c|}{ Average chemical composition. } & \multirow{2}{*}{$\begin{array}{l}\text { Average } \\
\text { pounds of } \\
\text { water evap- } \\
\text { orated } \\
\text { from and at } \\
212^{\circ} \mathrm{F} \text {. per } \\
\text { pound of } \\
\text { dry coal. }\end{array}$} \\
\hline & & $\begin{array}{l}\text { Mois- } \\
\text { ture. }\end{array}$ & $\begin{array}{l}\text { Volatile } \\
\text { matter. }\end{array}$ & $\begin{array}{c}\text { Fixed } \\
\text { carbon. }\end{array}$ & Ash. & $\begin{array}{l}\text { Sul- } \\
\text { phur. }\end{array}$ & \\
\hline 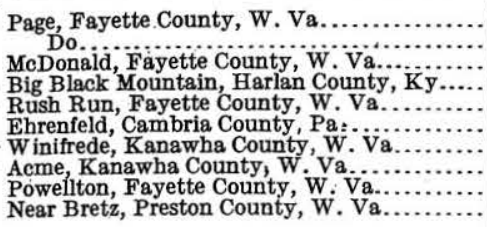 & $\begin{array}{l}2 \\
1 \\
2 \\
2 \\
2 \\
5 \\
4 \\
4 \\
4 \\
1 \\
3\end{array}$ & $\begin{array}{l}\text { 4. } 06 \\
\text { 2. } 85 \\
\text { 2. } 75 \\
\text { 5. } 06 \\
\text { 2. } 12 \\
\text { 2. } 38 \\
\text { 3. } 79 \\
2.93 \\
\text { 3. } 42 \\
\text { 4. } 20\end{array}$ & $\begin{array}{l}30.35 \\
30.13 \\
20.59 \\
34.77 \\
21.91 \\
16.53 \\
35.33 \\
32.66 \\
31.11 \\
28.05\end{array}$ & $\begin{array}{l}61.54 \\
64.78 \\
70.05 \\
56.31 \\
70.73 \\
74.47 \\
55.76 \\
57.64 \\
59.47 \\
60.86\end{array}$ & $\begin{array}{l}4.05 \\
2.24 \\
6.61 \\
3.86 \\
5.24 \\
6.62 \\
5.12 \\
6.77 \\
6.00 \\
6.89\end{array}$ & $\begin{array}{r}0.90 \\
1.06 \\
.98 \\
.56 \\
.67 \\
.95 \\
1.11 \\
1.23 \\
.82 \\
1.28\end{array}$ & $\begin{array}{l}10.545 \\
10.52 \\
10.36 \\
10.26 \\
10.195 \\
10.186 \\
10.16 \\
10.115 \\
10.09 \\
10.07\end{array}$ \\
\hline
\end{tabular}

The results of tests on the Ehrenfeld samples, although showing a range of 9.75 to 10.42 pounds of water evaporated per pound of dry coal used, are yet, when averaged, among the very best obtained at the testing plant. Each sample submitted to the steaming test was analyzed, and the accompanying analyses represent averages of the total number made, as do the figures representing the efficiency of the coals as steam producers. It is of interest to note that the Ehrenfeld coal contains the largest percentage of fixed carbon and the lowest amount of volatile matter of all the samples.

Other samples of the Lower Kittanning coal tested by the United States fuel-testing plant from January 1, 1906, to June 30, 1907, include a few from in or near this quadrangle. The results of these tests are given below, together with the analyses of the samples tested. For comparison the results (given above) from the Ehrenfeld coal are repeated.

Chemical composition and steaming values of typical Appalachian coals.

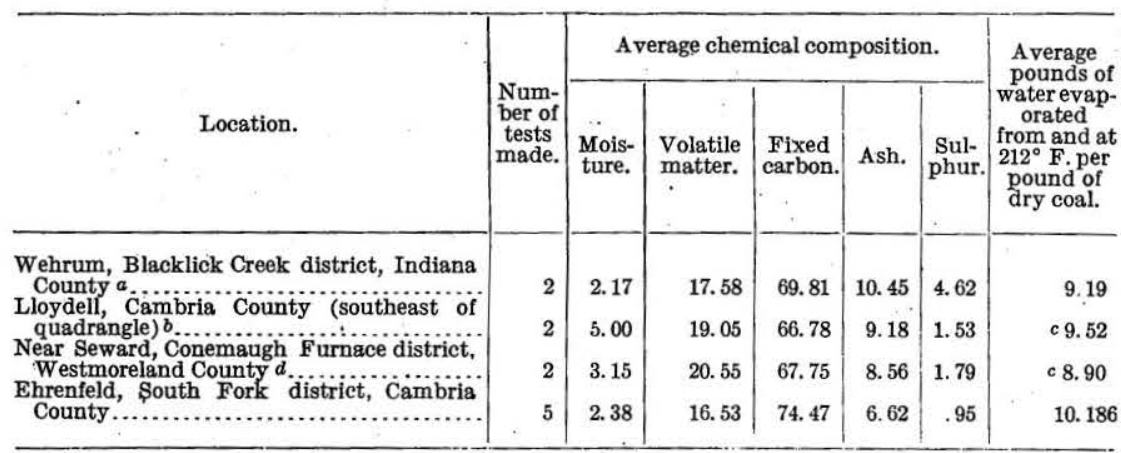

a Bull. U. S. Geol. Survey No. 332, 1908, pp. 201, 202.

$b$ Idem, pp. 210, 211. Lloydell is on the east flank of the Wilmore Basin and on the quadrangle to the east.

$c$ Test made on briquets from the coal.

$d$ Bull. U. S. Geol. Survey No. 332, 1908, pp. 216, 217. 
The figures obtained in the last column give comparative commercial values which show the high grade of the Lower Kittanning coal as coal or in briquet form in and near the quadrangle. It is of interest to see how the analysis and steaming values of the coal collected at Lloydell on the east flank of the Wilmore Basin compare with the results obtained near Seward in the area to the west. For the details of the conditions governing these steaming tests the reader is referred to Bulletin 332 .

\section{COKING TESTS.}

The Lower Kittanning (Miller) coal is coked, but it does not rank so high as a coking coal as it does as a steam producer. Tests on samples yielded the following results:

Coking tests on Lower Kittanning coal in Johnstown quadrangle.

\begin{tabular}{|c|c|c|c|c|c|}
\hline & 1: & 2. & 3. & 4. & 5. \\
\hline 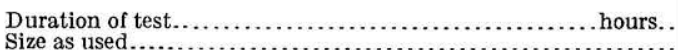 & $(a)^{51}$ & $(a)^{61}$ & $(b)^{54}$ & $(a)^{68}$ & ${ }_{(t 1)}^{78}$ \\
\hline 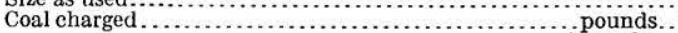 & 10.000 & 9,750 & 12,460 & 13,070 & 11. 760 \\
\hline Coke produced............... & 5,223 & 5,779 & 8,144 & 8,129 & 7.350 \\
\hline$\cdots$ per cent.. & 52.23 & 59.27 & 65.36 & 62.20 & 62.50 \\
\hline Breeze produced.. & 1,600 & 262 & 332 & 420 & 529 \\
\hline Total yield & $\begin{array}{l}16.00 \\
68.23\end{array}$ & $\begin{array}{r}2.69 \\
61.96\end{array}$ & $\begin{array}{r}2.66 \\
68.02\end{array}$ & 3. 21 & 4. 50 \\
\hline & & & 08.02 & 05.41 & 0.00 \\
\hline
\end{tabular}

Analyses of Lower Kittanning coal and of coke made from it.

\begin{tabular}{|c|c|c|c|c|c|c|c|c|c|c|}
\hline & \multicolumn{2}{|c|}{1.} & \multicolumn{2}{|c|}{2.} & \multicolumn{2}{|c|}{3.} & \multicolumn{2}{|c|}{4.} & \multicolumn{2}{|c|}{5.} \\
\hline & Coal. & Coke. & Coal. & Coke. & Coal. & Coke. & Coal. & Coke. & Coal. & Cole. \\
\hline 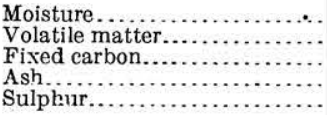 & $\begin{array}{r}3.32 \\
15.56 \\
74.29 \\
6.83 \\
1.12\end{array}$ & $\begin{array}{r}0.91 \\
2.16 \\
88.99 \\
7.94 \\
.91\end{array}$ & $\begin{array}{r}7.19 \\
17.86 \\
69.57 \\
5.38 \\
1.63\end{array}$ & $\begin{array}{r}0.56 \\
.32 \\
91.10 \\
8.02 \\
1.46\end{array}$ & $\begin{array}{r}4.53 \\
18.56 \\
70.63 \\
6.28 \\
1.85\end{array}$ & $\begin{array}{r}0.57 \\
.55 \\
90.23 \\
8.65 \\
1.54\end{array}$ & $\begin{array}{r}3.91 \\
16.35 \\
68.30 \\
11.44 \\
2.78\end{array}$ & $\begin{array}{r}0.30 \\
.28 \\
84.95 \\
14.47 \\
2.31\end{array}$ & $\begin{array}{r}6.30 \\
17.04 \\
69.58 \\
7.08 \\
1.34\end{array}$ & $\begin{array}{r}0.51 \\
.58 \\
89.85 \\
9.06 \\
1.11\end{array}$ \\
\hline
\end{tabular}

1. Raw bituminous coal from mine No. 3, Pennsylvania Coal and Coke Company, Ehrenfeld, collected under supervision of J. S. Burrows. Bull. U. S. Geol. Survey No. 290, 1906, p. 181.

2 and 3 . Washed run-of-mine coal from Wehrum, collected under supervision of John W. Groves. Bull. U. S. Geol. Survey No. 332, 1908, p. 203.

4. Raw run-of-mine coal from a mine $1 \frac{1}{2}$ miles east of Seward, collected under supervision of John W. Groves. Bull. U. S. Geol. Survey No. 332,1908 , p. 218.

5. Washed run-of-mine coal from same locality as No. 4.

The results obtained from the coking tests were as follows:

The coke from Lower Kittanning coal collected at Ehrenfeld (No. 1) was soft and dense, dull gray in color, with a heavy black butt. It broke in large and small chunks and was difficult to' burn. The cell structure was small.

The coke from the first test (No. 2) on the Wehrum sample was soft and dense and dull gray in color. The high content in sulphur is worthy of note. The coke from the second test (No. 3) on the Wehrum 
sample was light gray or silvery in color and much better than the coke from the finely crushed coal (No. 2). It also was high in sulphur. The coke from the first test (No. 4) on the sample collected $1 \frac{1}{2}$ miles east of Seward was light gray or silvery in color and was soft and dense, with high ash and sulphur. The coke from the second test (No. 5) was gray in color; washing produced no change in its physical appearance though it reduced the ash and sulphur slightly. As in the test No. 4, the coke was soft and dense.

It may be added that the yield of coke in all the above tests is high. The coal mined at Franklin (analysis 11, p. 40) is coked by the Cambria Steel Company. in by-product ovens for use in the company's plant near Johnstown and gives satisfactory results. The coal is washed before coking, thereby adding to the cost, but even with this additional expense it is found cheaper to coke this coal on the ground than to buy coke of better quality from the Connellsville region. Tests have been made by the Cambria Steel Company with the coal mined from this bed about Ehrenfeld, and the resulting coke proved well adapted to metallurgical purposes. The yield also was satisfactory. The coal mined at Nanty Glo from this bed has been tested in beehive ovens at Gallitzin. It produced coke of good structure but of a rather dull appearance. As was to be expected, an insufficient amount of sulphur was volatilized. At Bennington this coal, like the Upper Freeport, shows a higher content in volatile matter than it does about South Fork and Johnstown. The Lackawanna Coal and Coke Company has experimented with it about Wehrum, but the washeries have been shut down and the results of the coking tests were not learned. The results of Survey tests have already been given (p. 38). The Vinton Colliery Company has erected a byproduct plant at Vintondale, and in 1907 a considerable part of the coal mined from colliery No. 6 was coked.

\section{MISCELLANEOUS TESTS.}

Other tests have been made on the Lower Kittanning coal, such as producer-gas tests, washing tests, cupola tests, and briquetting tests. The details connected with these are given where this coal is considered in the different districts (pp. 71-76, 83-88, 98-100).

\section{LOWER ALLEGHENY COALS.}

The coals below the Lower Kittanning have not been extensively developed in this area. At South Fork a bed lying about 60 feet below the Miller coal and known locally as the Dirty A or Six-foot seam has been opened. It is possible that this corresponds to the Brookville (A) coal of the Allegheny Valley. It has a composition indicated by analysis 36 on pages $41-42$, and from the high ash and 


\section{MINERAL RESOURCES OF JOHNSTOWN, PA., AND VICINITY.}

sulphur content, aggregating more than 15 per cent, deserves the name which is often applied to it. In other respects the analysis corresponds with those of other coals of the area, being relatively high in fixed carbon and low in volatile matter.

\section{COMPOSITION OF THE COALS.}

The coals of the Johnstown quadrangle belong to the soft, lustrous, semibituminous variety. They are best adapted for steaming and domestic purposes, but some of them make also an excellent coke. They are classed as smokeless coals because of their small content of volatile hydrocarbons. They are uniformly high in carbon and contain small amounts of volatile matter and moisture. Their ash and sulphur contents are variable but in general terms high compared with other Appalachian coals-for instance, those of West Virginia and eastern Kentucky. Some analyses of samples collected accoriing to present Survey methods are listed below.

Analyses of coal samples from Johnstown quadrangle, Pennsylvania. . $_{\text {. }}$

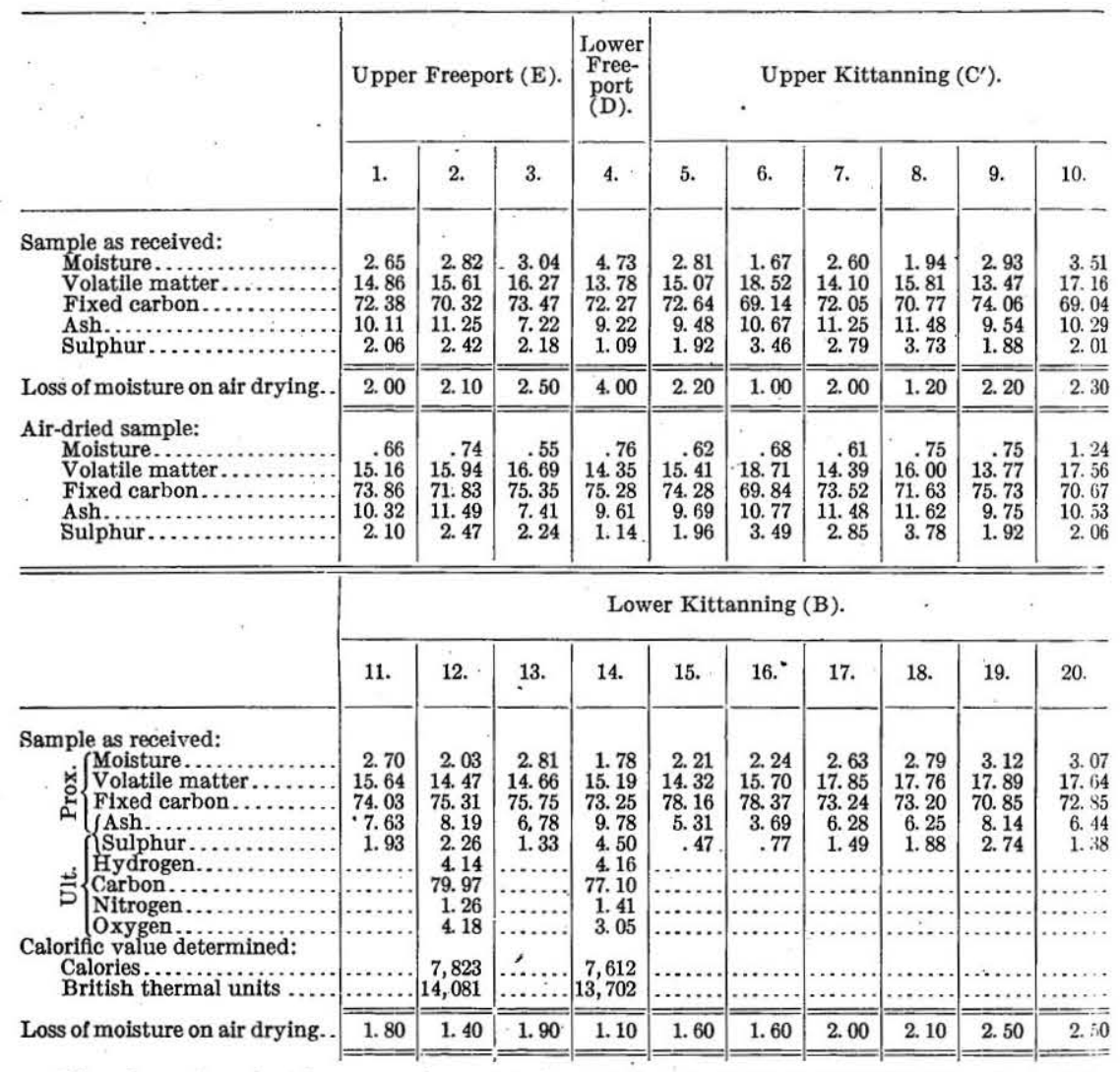

a All analyses given in this paper, unless otherwise stated, were made at the fuel-testing plant of the United States Geological Survey at St. Louis, Mo.; J. A. Holmes in charge; F. M. Stanton, chemist. 
COAL.

Analyses of coal samples from Johnstown quadrangle, Pennsylvania-Continued.

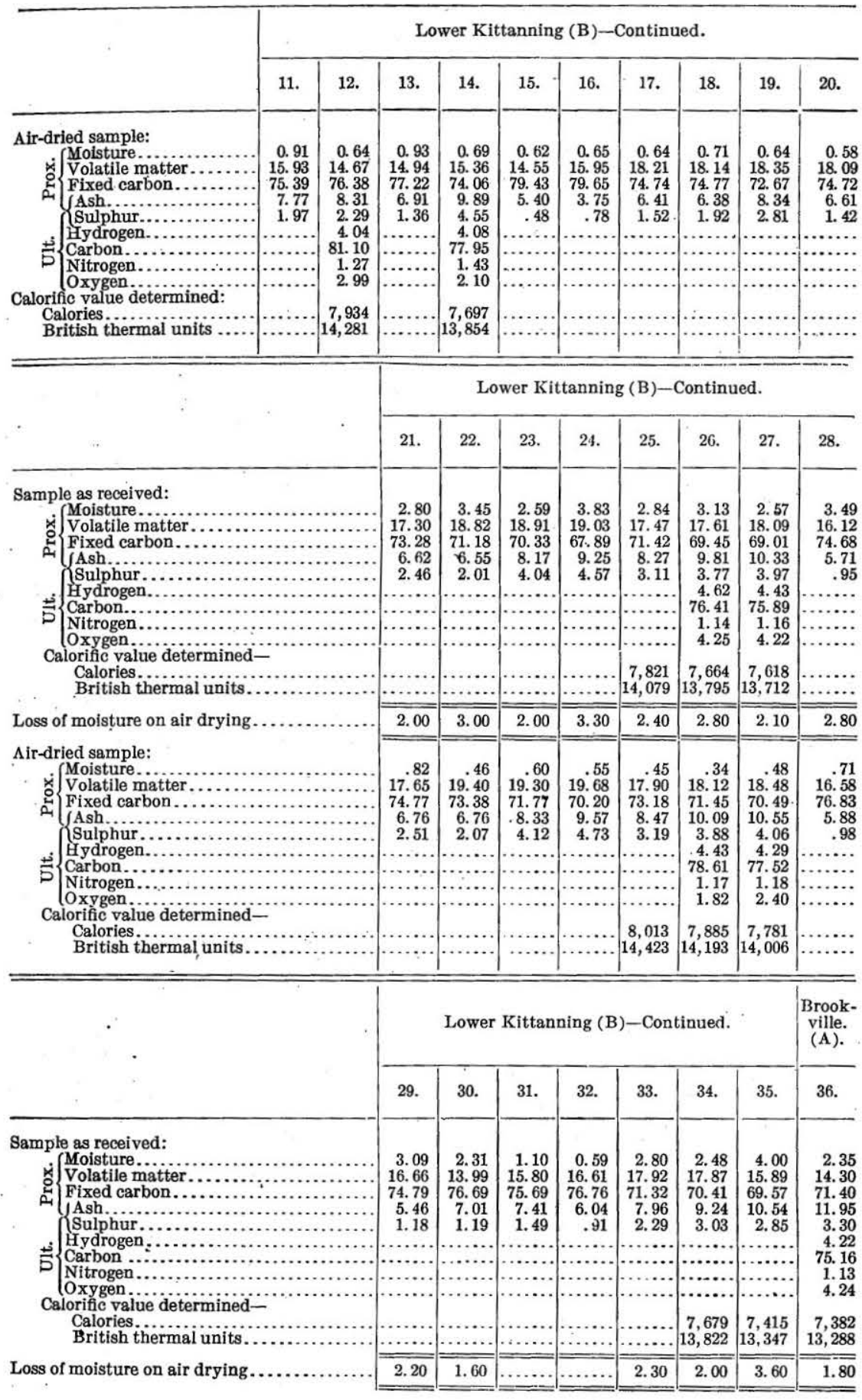


Analyses of coal samples from Johnstown quadrangle, Pennsylvania-Continued.

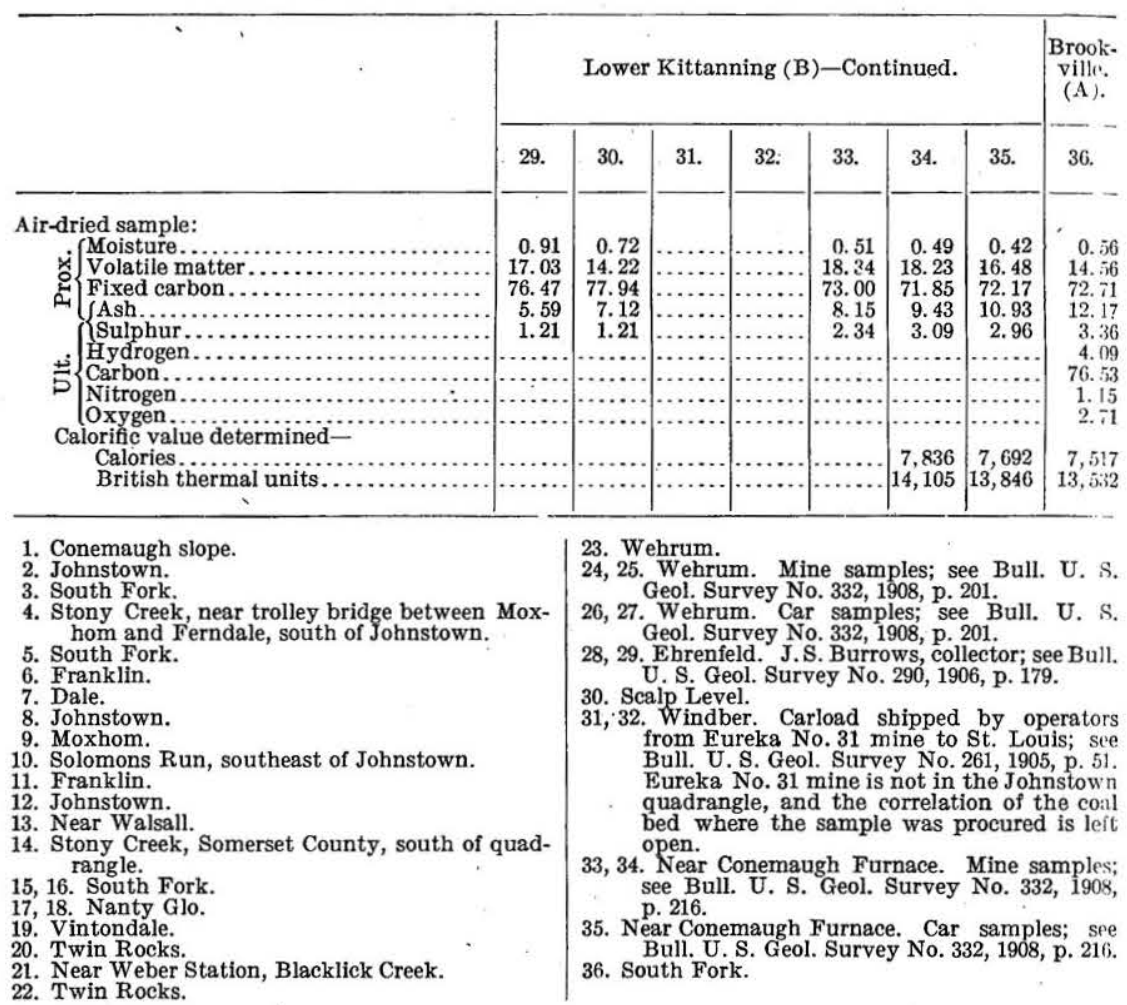

\section{DESCRIPTION BY DISTRICTS.}

For convenience in reference and from the commercial point of view the coal resources of the Johnstown quadrangle are described by districts, as follows: Johnstown district, South Fork-Mineral Point district, Blacklick Creek district, Windber district, and Conemaugh Furnace district. The territory included in these different districts will be outlined in the descriptions.

\section{JOHNSTOWN DISTRICT.}

EXTENT.

The Johnstown district includes the territory about the city of Johnstown and its suburbs; the hills along the valley of Conemaugh River, extending from East Conemaugh and Clapboard Run on the east to Laurel Run and the base of Laurel Ridge on the west; the region along Stony Creek and its tributaries, Solomons Run, Sams Run, and Bens Creek; and a few smaller areas back in the country and away from the channels of transportation. 
CONEMAUGH COALS.

CHARACTER AND DISTRIBUTION.

The Conemaugh formation outcrops in all the hills in the immediate vicinity of Johnstown. In a section of 300 feet of this formation measured by John Fulton ${ }^{a}$ above the Upper Freeport coal at Prossers Knob, near the city, but 3 inches of coal was detected about 65 feet above the Upper Freeport coal. A section was measured on the hill above the plant of the Johnstown Pressed Brick Company in which 400 feet of beds with concealed intervals were observed (see pp. 115-116), and no bed of coal was detected or reported as of workable thickness. It is probable, therefore, that in the Johnstown district the Conemaugh formation contains no bed of coal which under present conditions is of commercial importance.

GALLITZIN COAL.

In the vicinity of Johnstown the Gallitzin coal averages about 100 feet above the Upper Freeport coal. Some of the diamond-drill records obtained in the hills east of the city note a coal 1 foot in thickness slightly more than 100 feet above the Upper Freeport. The maximum thickness of this bed appears to be less than 2 feet and it is in places less than 1 foot thick. In some of the sections a coal appears as low as 70 feet above the Upper Freeport. Where there is but a single coal in the lower 110 feet of the Conemaugh it is difficult to decide whether it is the representative of the Gallitzin or of the next lower bed, the Mahoning coal. What is believed to be the equivalent of the Gallitzin has been noted well up on South Fork of Bens Creek, also on the west side of the hill south of Kring and west of Ingleside, and there is evidence that it has been prospected in both these localities. Its position was located on the Johnstown-Geistown road, along the trolley line south of Island Park. Where measured along the roadside it is very thin. It may be said that its occurrence in the Johnstown Basin is fairly widespread but that it is too thin to be classed among the future workable beds in this part of the quadrangle.

MAHONING COAL.

The Mahoning coal occurs very close to and above the Johnstown ore bed and between 50 and 55 feet above the Upper Freeport coal in the region near Johnstown. It consists where seen to best advantage of two benches, as shown in the following section measured above the Baltimore and Ohio Railroad tunnel on Stony Creek south of Johnstown:

a See pp. 17-18, this bulletin; also Second Geol. Survey Pennsylvania, vol. H2, 1877, p. 97. 


\section{MINERAL RESOURCES OF JOHNSTOWN, PA., AND VICINITY.}

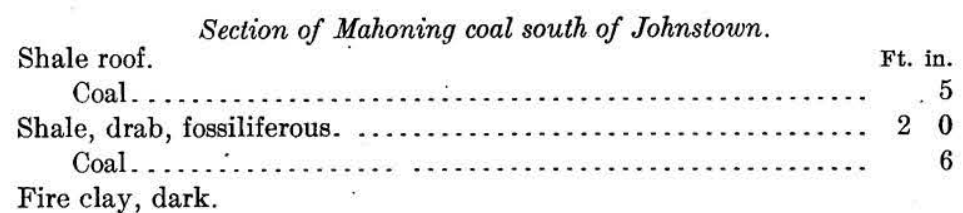

It is nowhere worked, so far as known, and it can not be considered among the future workable coals of the area.

ALLEGHENY COALS.

GEOLOGIC POSITION.

Four coals of workable thickness occur in the Allegheny formation in the Johnstown district-the Upper Freeport or Coke Yard bed, the Lower Freeport or Limestone bed, the Upper Kittanning or Cement bed, and the Lower Kittanning or Miller bed. These are also known by letters as the $\mathrm{E}, \mathrm{D}, \mathrm{C}^{\prime}$, and $\mathrm{B}$ coals, respectively. The Middle Kittanning also occurs, but so far as known is of workable thickness at only a few points and therefore can not be classed among the commercial coals of the district. All the coals except the Lower Kittanning lie at convenient intervals above drainage level in the hills immediately surrounding Johnstown and are extensively worked.

The entire Allegheny formation is exposed in the Johnstown district. Several sections obtained at widely scattered points serve well to illustrate the variations in the character of its rocks as well as the intervals which separate the coals. The sections were measured by hand leveling and by rule. Some of them are as follows:

(1) Section of upper part of Allegheny formation near Valley Coal and Stone Company s mine, on Stony Creek.
Coal, Upper Freeport ( $\mathrm{E}$ or Coke Yard coal)
Ft. in.
Shale..................................... 14
Shales, dark, concretionary .......................... 10

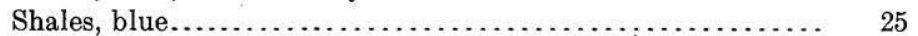

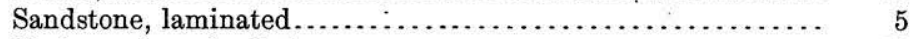
Shales and sandy shales............................... 10

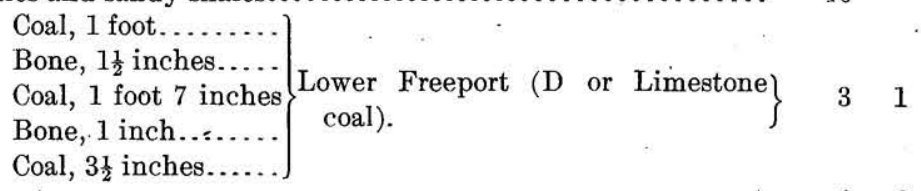

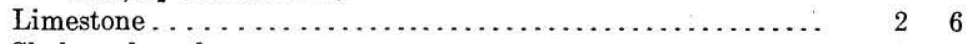

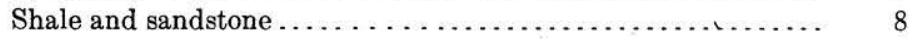

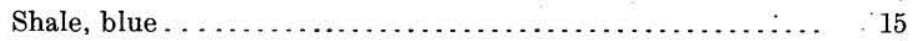
Coal, Upper Kittanning (Cement or C' coal) $\ldots \ldots \ldots \ldots\left\{\begin{array}{rr}4 & 9\end{array}\right.$
Shale . . . . . . . . . . . . 1

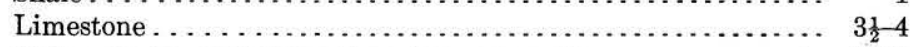
Shale, sandy, containing limestone concretions . . . . . . . 8 8-10
Sandstone, massive. 
The interval between the Upper Freeport and Upper Kittanning coals in the above section is about 90 feet.

The section is carried still lower by one measured south of the tunnel on the Baltimore and Ohio Railroad, which shows the relative positions of two small beds occurring between the Upper Kittanning or Cement bed and the Lower Kittanning or Miller bed. This section is as follows:

(2) Section of Upper Kittanning coal and underlying coals south of tunnel on Baltimore and Ohio Railroad.

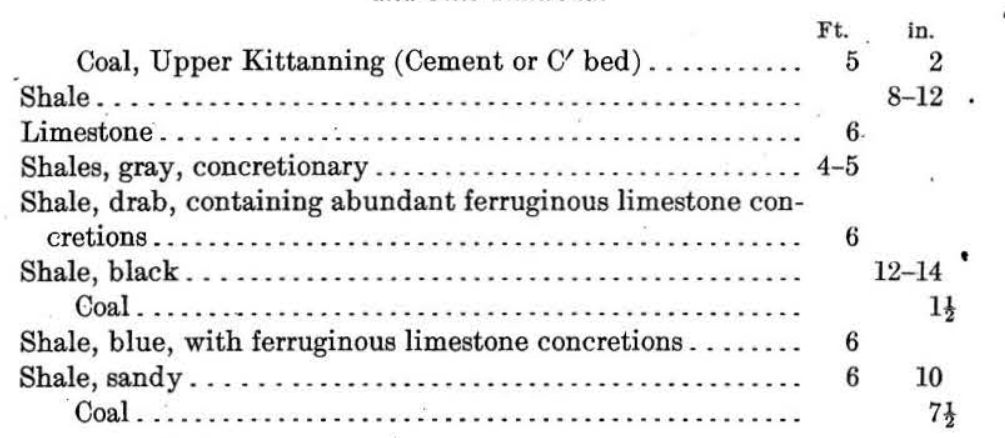

The intervals between the three main coals in the upper part of the Allegheny formation, as well as the character of the intermediate rocks, are given in the following section obtained in the ventilating shaft of the Rolling Mill mine of the Cambria Steel Company on Mill Creek:

(3) Section of upper part of Allegheny formation on Mill Creek.

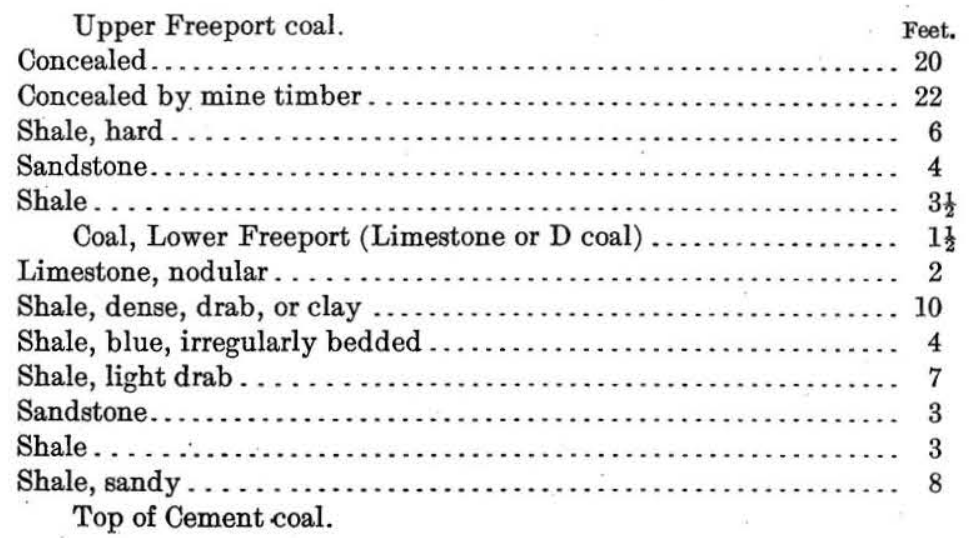

The interval between the Upper Freeport and Upper Kittanning coals here is between 90 and 95 feet.

The following section was measured by F. B. Peck and W. C. Phalen on the Eighth Ward road, south of Kernville: 
(4) Section of upper part of Allegheny formation on Eighth Ward road, south of Kernville.

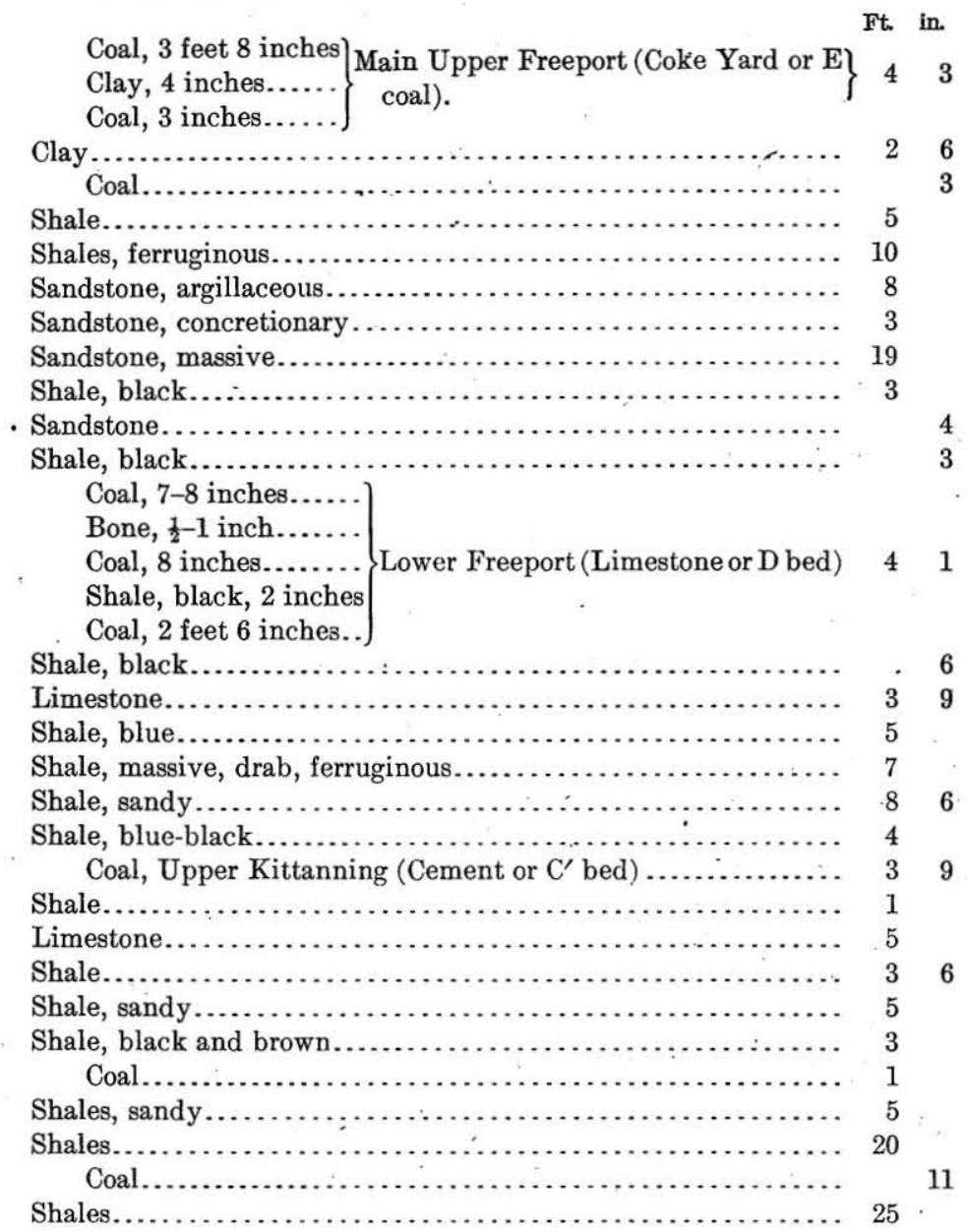

The interval here between the Upper Freeport and the Upper Kittanning coals is about 85 feet.

The following section is of interest, as it shows a coal between the Lower Freeport and Upper Kittanning beds, presumably the same bed as that above the Upper Kittanning at the mouth of the Rolling Mill mine and on Dalton Run.

(5) Section of upper part of Allegheny formation south of stone bridge on Stony Creek, Johnstown.

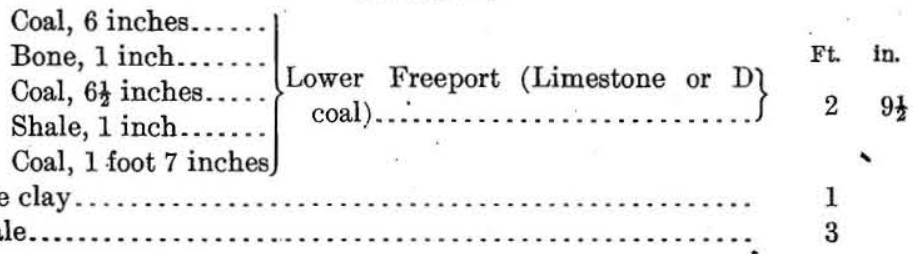

Shale........................................... 3 


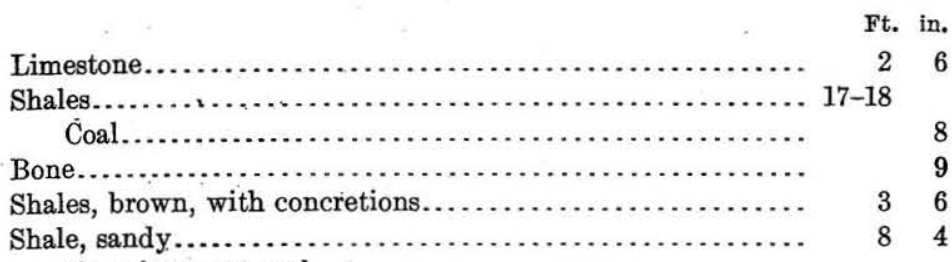

Top of cement coal.

The following section was measured in a small gully on the main line of the Pennsylvania Railroad half a mile east of Conemaugh depot.

(6) Section of upper part of Allegheny formation on Pennsylvania Railroad east of East Conemaugh.

Coal, 3 feet 3 inches

Bone, 2 inches..... Upper Freeport (Coke Yard or E coal). $39 \frac{1}{2}$

Coal, $4 \frac{1}{2}$ inches......

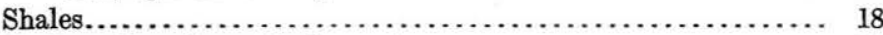

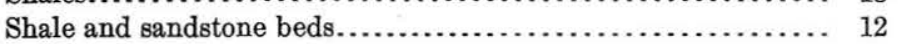

Shales.......................................... 40

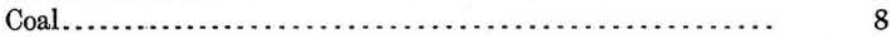

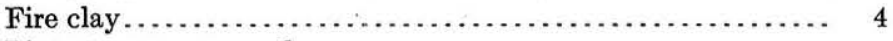

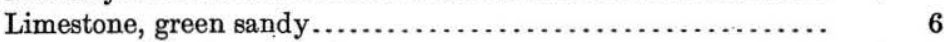

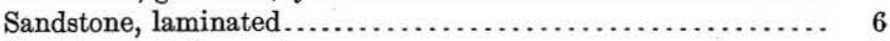

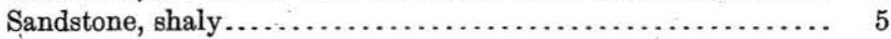

Sandstone, massive............................... 40

Coal, Upper Kittanning (Cement or $\mathrm{C}^{\prime}$ coal)................ $211 \frac{1}{2}$

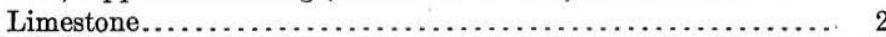

Shale, gray, with limestone nodules.................. 1

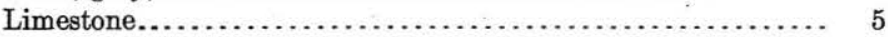

Shale, gray, with ferruginous concretions............... 5

shales, blue.................................... 17

Railroad level.

Shale, blue, with ferruginous limestone concretions........... 10

Limestone nodules, blue, to creek level.

The above section was completed down to the Lower Kittanning coal by a section a short distance to the west. Part of it could not be hand leveled but had to be measured by barometer. The section is as follows:

(7) Section between Upper Kittanning $\left(C^{\prime}\right)$ and Lower Kittanning $(B)$ coals.

Base of Upper Kittanning ( $\mathrm{C}^{\prime}$ or Cement coal).

Shales, bluish and gray (containing a small coal locally), with concretions; 40 feet of these shales are represented in the preceding section.

Ft. in.

Coal.

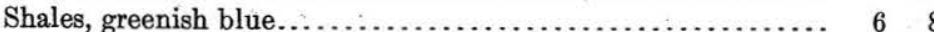

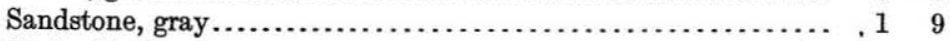

Shale, black...................................... 15

Sandstone, blue, thick bedded...................... 5 .

Approximate interval made up chiefly of sandstone to Lower Kittanning (Miller or B bed) 
The above sections well illustrate the character of the Allegheny rocks between the Lower Kittanning (Miller) coal and the Upper Freeport (Coke Yard) bed. The opportunities for measuring the interval from the Lower Kittanning to the top of the Pottsville are rare near Johnstown. On Clapboard Run this interval is about 70 feet. On Stony Creek south of the area the character of the rocks making up the interval was carefully determined and the section hand leveled. This section of the lower Allegheny is as follows:

(8) Section from top of Pottsville to Lower Kittanning (Miller or B coal) on Stony Creek, south of Johnstown quadrangle.

Coal, 3 feet $8 \frac{1}{2}$ inches

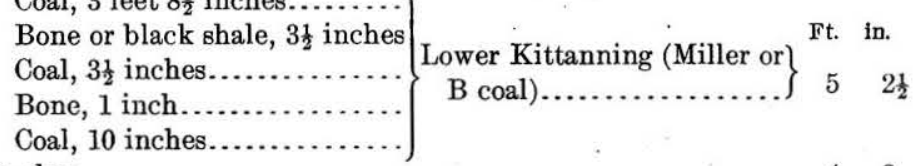

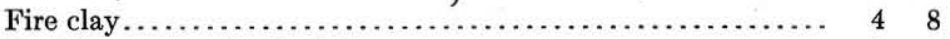

Sandstone, gray, laminated..................... $9 . \ldots$

Sandstone, massive............................ 40

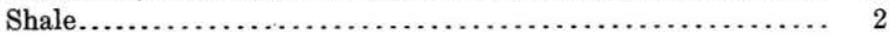

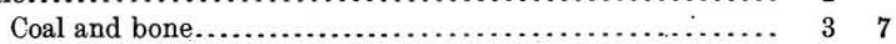

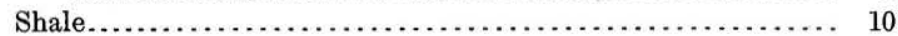

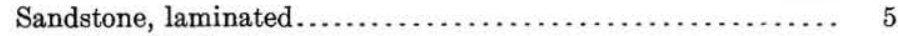

Top of Pottsville.

The interval from the base of the Lower Kittanning coal to the top of the Pottsville here is about 75 feet, which is very close to the interval of 70 feet measured on Clapboard Run.

In this section but one coal appears between the top of the Pottsville and the base of the Lower Kittanning (Miller) bed, but in places two coals occur in this interval, as in the section of the lower Allegheny rocks obtained near the brick plant of A. J. Haws \& Sons (Limited), west of Coopersdale. (See p. 24, fig. 2, section A.)

Many other measurements of the intervals between the coals of the Allegheny were obtained in and near Johnstown. (See fig. 2.) These intervals and those brought out in the sections given above will be described in detail in considering the stratigraphy of the individual coal beds.

UPPER FREEPORT COAL.

Name and position.-In the Johnstown district the Upper Freeport or top coal of the Allegheny formation is commonly known as the Coke Yard coal, from the fact that it was coked in the early days of the iron industry at the old Cambria furnace on Laurel Run. It is also frequently referred to as the $\mathrm{E}$ coal. It lies at the top, indeed marks the top, of the Allegheny formation, being separated from the usually massive Mahoning sandstone member (of the Conemaugh formation) above by a few feet of shales, and being located between 255 and 265 feet above the top of the Pottsville formation, or "Conglomer- 
U. S. GEOLOGICAL SURVEY

BULLETIN 447 PLATE VII

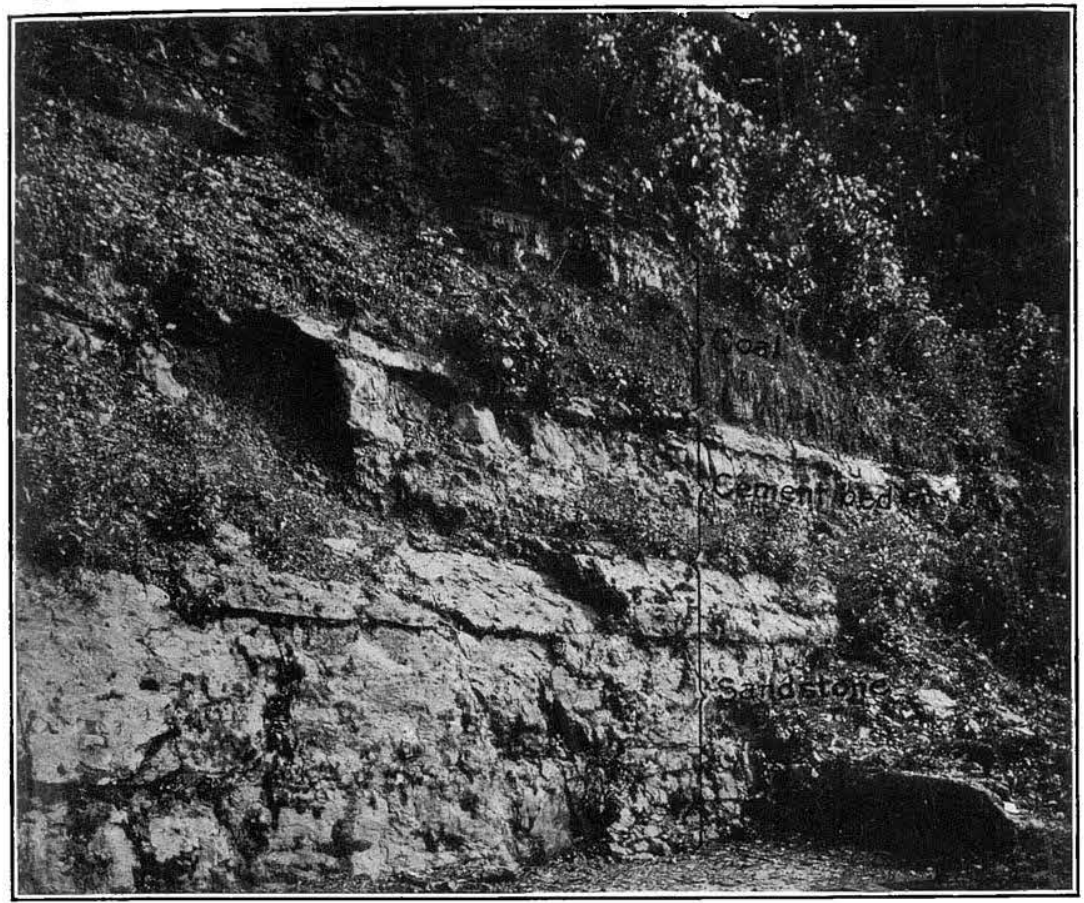

A. EXPOSURE OF UPPER KITTANNING COAL AND JOHNSTOWN LIMESTONE MEMBER ("CEMENT BED" IN THE ILLUSTRATION) ON STONY CREEK, NEAR MINE OF VALLEY COAL AND STONE COMPANY.

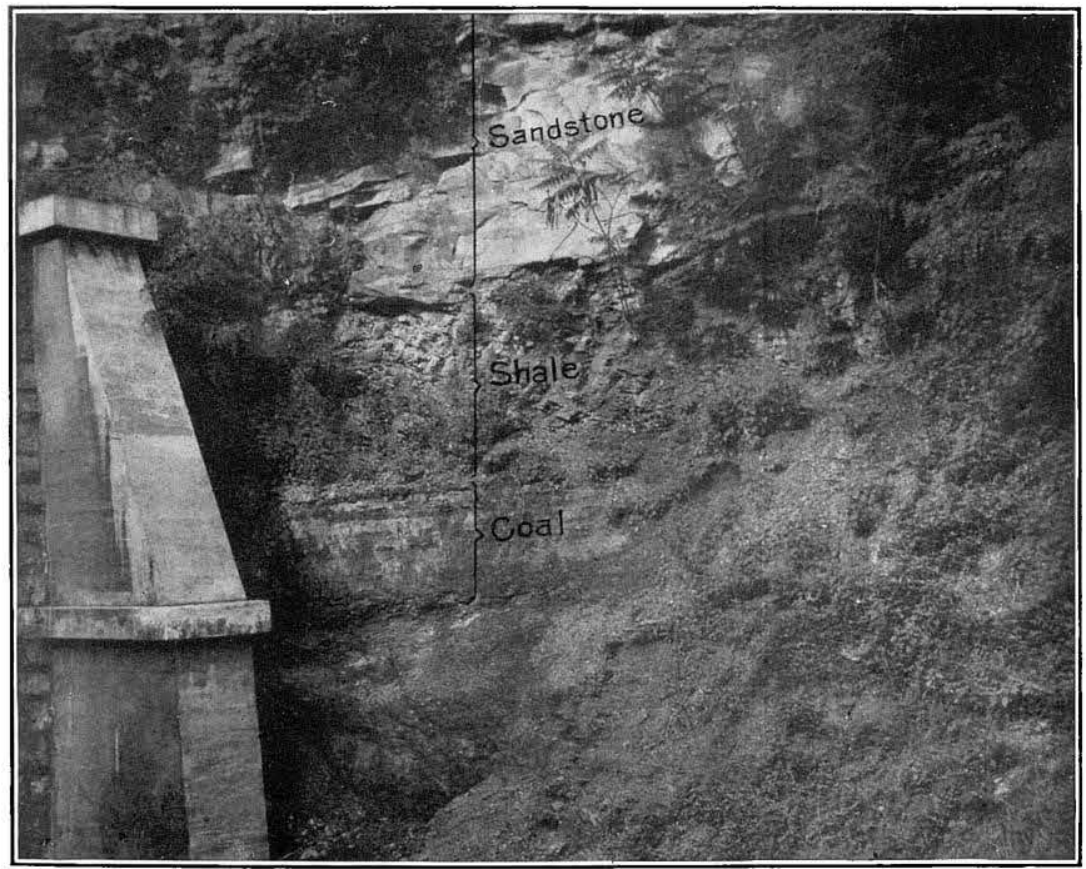

B. UPPER FREEPORT COAL WITH OVERLYING SHALES AND BASE OF MAHONING SANDSTONE AT SOUTH PORTAL OF BALTIMORE AND OHIO RAILROAD TUNNEL, STONY CREEK. 

ate Rock," as it is popularly known. Its relation to the other coals in the Allegheny formation are shown in figure 2 and may be learned from most of the sections just given (pp. 44-47).

Extent and development.-The Upper Freeport is present in all the hills along Conemaugh River near the city and its suburbs, extending as far to the west as the hills bordering east of Laurel Run. It is also above drainage level on Clapboard, Hinckston, and St. Clair runs and practically along the entire course of Stony Creek and its tributaries, Solomons and Sams runs. It is not above drainage level through the entire course of Bens Creek in this area, as the synclinal trough in Somerset County causes its disappearance for a short distance, but even there it is not deeply buried. Plate I gives an excellent idea of its outcrop in the vicinity of Johnstown.

Wherever the coal is exposed it has been worked fairly extensively, and it is now being worked on a large scale in many mines about Johnstown. The most important workings are those of the Cambria Steel Company at the Conemaugh slope. The Ferndale Coal Company also operates on an extensive scale. Many smaller mines on this coal bed are worked the year round, and many small banks, from which coal is never shipped by rail, are worked only during the winter season. The most important mines on this coal are indicated on Plate I.

Chemical character.-The composition of the Upper Freeport coal in the Johnstown district is shown in analyses 1 and 2, on page 40. These analyses indicate this coal to be a high-carbon coal with comparatively low moisture. The ash and the sulphur are high.

Occurrence and physical character.-Average and typical sections of the Upper Freeport coal in the Johnstown district are shown in figure 4. The main bench averages between 3 feet and 3 feet 10 inches in thickness, more nearly the former than the latter. In places there is present a lower bench, which only exceptionally (as the moine of Lewis Eppley, on Hinckston Run) exceeds 4 or 5 inches in thickness. This lower bench is separated from the main bench by a thin bone or shale parting rarely more than 5 or 6 inches thick. The lower part of the coal bed is in some places so intinate a mixture of coal and bone that it is difficult to differentiate the two Such is the ease in section 19, obtained at the south portal of the tunel of the Baltimore and Ohio Railroad on Stony Creek. (See Pl. VII, A) At a bank on Bens Creek the coal shows a seetion (No. 21) quite different from the usual one, but this section was obtained at a point several miles away from most of the other sections, and the lack of measurements in the intermediate territory makes it impessible to state whether the thinning shown is local or general to the west of the Johnstown Basin. However, to the north of this point, on St. Clair

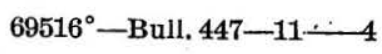

LIBKARY

TEXAS TECHNOLOGICAL COLLEGE LUBBOCK, TEXAS 
Run, the section seems to be as usual. Only the main bench of this coal is ever worked, and all the coal below the main bench serves as a floor, except where it is necessary to remove it for head room.

As a rule no partings were noted in the main bench of this coal in the Johnstown district, a particular in which it differs markedly from the equivalent bed about South Fork and along the southeastern flank of the Wilmore Basin. Its maximum thickness nowhere exceeds 5 feet and usually ranges near 4 feet. The minimum thickness may
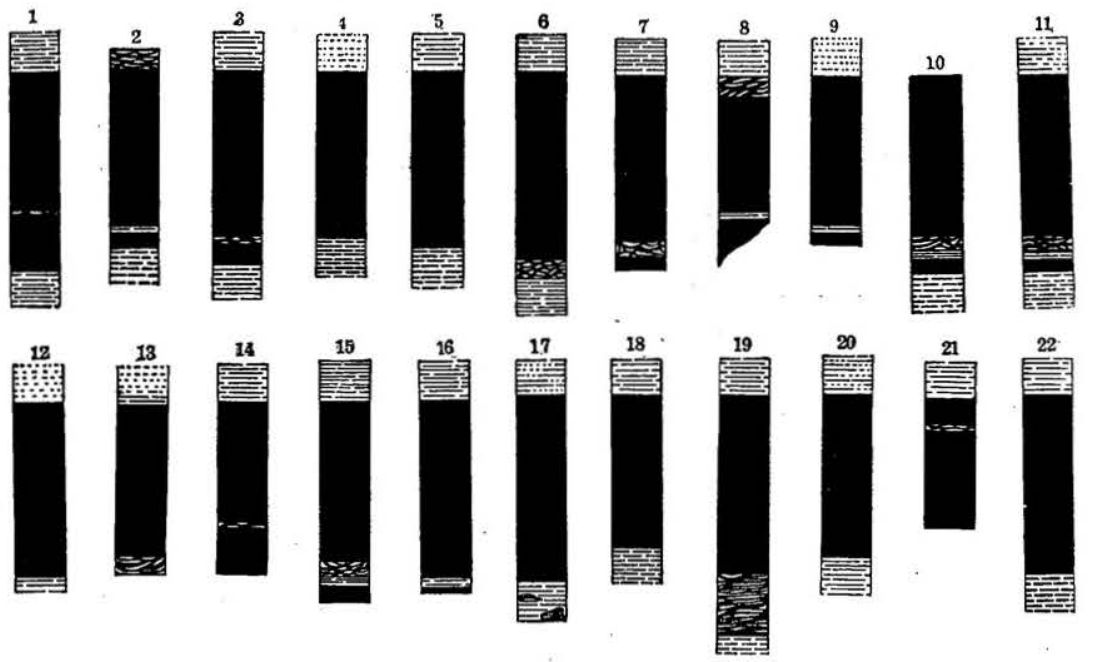

Figure 4.-Sections of the Upper Freeport ( $\mathrm{E}$ or Coke Yard) coal in the Johnstown district. Scale, 1 inch $=5$ feet.

1. Lewis Eppley, Hinckston Run, above Rosedale.

2. Conemaugh slope, Cambria Steel Company, west of East Conemaugh.

3. Country bank in ravine, north of Pennsylvania Railroad, northeast of East Conemaugh.

4. L. J. Mitchell, mouth of Clapboard Run.

5. Charles Umbarger, head of Clapboard Run.

6. Johnstown Pressed Brick Company, Frankstown road.

7. William Davis, Frankstown road.

8. William Schaeffer, Shingle Run, Dale.

9, 10,11, 12. Berkebile Coal Company, Dale, north of Moxhom.

13. Country bank, Sams Run, just above Highland Coal and Coke Company's mine.

14. Ferndale Coal Company, Grubtown opening

15. Ferndale Coal Company.

16. Country bank, Roxbury.

17. Natural exposure along trolley line, opposite Valley Coal and Stone Company's mine.

18. Natural exposure along trolley line, south of Island Park.

19. South portal of Baltimore and Ohio Railroad tunnel, south of Johnstown.

20. Natural exposure on Stony Creek near mine of Valley Coal and Stone Company.

21. Bens Creek, Somerset County.

22. Country bank, St. Clair Run.

be regarded as 2 feet, though, as in all coal beds, local rolls pinch the coal out altogether. Such rolls, however, appear to be extremely rare in this coal bed, which is characterized by marked uniformity. There are few or no clay veins. The roof is usually shale or shaly sandstone, in places bony. It is generally firm, but draw slate is occasionally reported. In some of the mines great care is taken in propping to prevent falls. 
LOWER FREEPORT COAL.

- Name and position.-The next lower coal of importance in the Allegheny formation in the Johnstown district is the Lower Freeport or D coal. It is popularly known as the Limestone coal, and is better known about Johnstown under this name than under either of the other two.

It lies from 50 to 65 feet below the Upper Freeport (Coke Yard) coal and from 25 to 36 feet above the Upper Kittanning (Cement) coal in the valley of Stony Creek, both south and west of Johnstown. On Mill Creek it is 55 feet below the Upper Freeport coal and about 37 feet above the Upper Kittanning coal. On Peggys Run, near the Franklin mine of the Cambria Steel Company, it is 58 feet below the Upper Freeport and 45 feet above the Upper Kittanning, which is here worked. In section 6 , page 47 , the 8 -inch coal 35 feet below the Upper Freeport coal may not be the representative of the Lower Freeport; certainly its distance below the Upper Freeport is very much less than that usual in the district as a whole.

Extent and development.-The Lower Freeport coal is above drainage level, as is the Upper Freeport bed, in all the hills near Johnstown, outcropping along Conemaugh River, Stony Creek, and their tributaries. Its outcrop line, if drawn on the map (Pl. I), would fall between that of the Upper Freeport and Upper Kittanning coals.

The coal has been prospected at many points about the city and its suburbs, but it is not mined, at least on a commercial scale, at the present time. The most promising outcrops were observed along Stony Creek from the vicinity of the mines of the Valley Coal and Stone Company northward to Roxbury. On Peggys Run, near Franklin, it was prospected and proved to be 4 feet thick but so badly broken by partings that it is not commercially valuable. It is reported 18 inches thick with a shale band in the middle in the hills north of Coopersdale. It is believed to be one of the important coals of the future in this district, especially along Stony Creek.

Chemical character.-In the sample of coal collected south of Johnstown, the analysis of which is given on page 40 (No. 4), the clay partings were not included, as these will be discarded when the coal is worked on a commercial scale.

In the analysis the percentage of carbon is high and comparable with this constituent in other coals in this district. The moisture can not be considered representative, as the sample was procured near the outcrop. The ash runs rather high but not above the average of the coals of the area. The coal from this bed is not considered good in the region about Johnstown, but the analysis of the sample collected near Stony Creek (see p. 40) indicates that in this locality, where the coal is persistent and of workable thickness, it has commercial importance. 
Occurrence and physical character.-The Lower Freeport coal occurs as a rule in three distinct benches (see fig. 5) in the territory about Johnstown and from Ferndale southward on Stony Creek. These benches are separated by thin shale or bone partings. The top bench averages about a foot in thickness and the middle bench about 2 feet. In the commercial development of this coal bed only these two benches will be worked, the underlying coal and bone serving as a floor. It may be said, therefore, that in this locality there is present from $2 \frac{1}{2}$ to 3 feet of coal. Southeast of Johnstown, at Dale and on Sams and Solomons runs, where this coal was measured by F. B. Peck and Lawrence Martin, a thin bench, usually under 6 inches, occurs at the top of the bed, and the two main benches are below, separated by bone or shale. In this part of the district these two workable benches do not average as much coal as in the workable parts of the bed on Stony Creek.
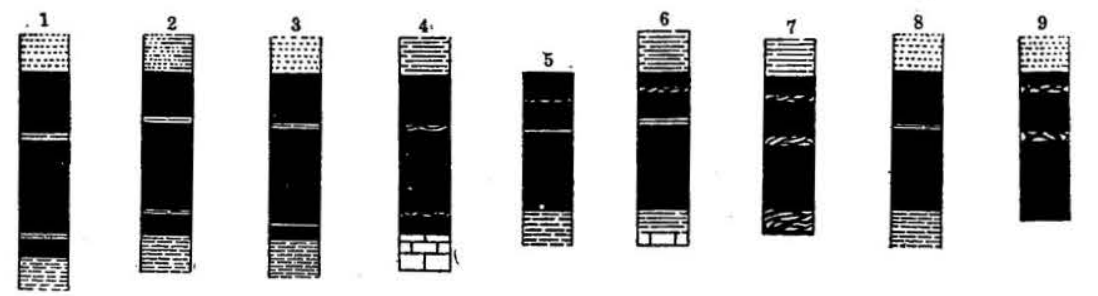

Figure 5.-Sections of the Lower Freeport (D or Limestone) coal in the Johnstown district. Scale, 1 inch $=5$ feet.

1. Natural exposure south of Kernville, near Citizens Eighth Ward mine.

2. Exposure on Baltimore and Ohio Railroad, weet bank of Stony Creek, opposite Lorraine Steel Com. pany's plant.

3. Stony Creek near trolley bridge.

4. Stony Creek near Valley Coal and Stone Company's mine.

5. West bank of Stony Creek, Johnstown.

6. Sams Run.

7. Dale.

8, 9. Head of Solomons Run.

Immediately over the coal are usually a few inches of bone and black shale overlain by dense shale, sandy shale, or massive sandstone. Plate IV, $A$ (p. 24), gives an idea of the character of this roof. The coal is underlain by clay, below which occurs the limestone, though in places the limestone underlies the coal directly.

UPPER KITTANNING COAL.

Name and position.- The next lower coal of importance in this district is the Upper Kittanning coal. It is also referred to as the $\mathrm{C}^{\prime}$ coal, but more commonly is known as the Cement seam, from the bed of cement rock which closely underlies it. In the early reports of the Second Geological Survey, of Pennsylvania it was called the Lower Freeport or D coal and the coal next above it was referred to as the Middle Freeport or $\mathrm{D}^{\prime}$ bed. $^{a}$ 
The Upper Kittanning coal commonly occurs within 100 feet of the Upper Freeport (Coke Yard) bed. At Kernville the interval between the two is about 90 feet; on Stony Creek near the Valley Coal and Stone Company's mine it is 90 feet; on Mill Creek, between 90 and 95 feet; south of Kernville, on the trolley line, 84 feet. On the Frankstown road an interval of about 100 feet was measured, though it was reported that the two coals locally occur as near to each other as 80 feet. Along the main line of the Pennsylvania Railroad just east of Conemaugh depot the interval is 90 feet, and near the Franklin mines it was reported as 103 feet. It can be stated, therefore, that about 95 feet below the Upper Freeport (Coke Yard) coal the prospector may expect to find the representative of the Upper Kittanning (Cement) coal in the Johnstown district. Sections 1, 3,4 , and 6 , on pages 44 to 47 , and the compiled sections obtained near Coopersdale and on Clapboard and Peggys runs (fig. 2) clearly indicate its relation to all the coals in this district.

Extent and development.-The Upper Kittanning (Cement) seam outcrops at a height above drainage level that is convenient for exploitation at practically all points about Johnstown. West of the city and north of Conemaugh River the coal is worked on the estate of Lewis J. Prosser, at the north end of Ten Acre Bridge. Here the coal is just below the flood-plain level at the base of the hill and has to be reached by slopes. A short distance to the west, just back of Coopersdale, a slight rise in the beds brings this coal above the flood plain, and a few abandoned banks indicate that it was formerly worked on a small scale here. The steep rise in the formations toward the west does not allow it to appear in the hills west of Laurel Run. To the east of the synclinal axis along Hinckston Run the coal is above drainage level and was worked just above the present location of Johnstown depot. Though not now exposed at that exact point, the fairly massive sandstone which usually overlies it is well exposed near the position of the old Ray furnace. A very short distance to the east the coal appears in the cliffs bordering the railroad, and it may be traced beyond Conemaugh depot. At present there are no workings of note on it east of Johnstown depot and north of the Little Conemaugh, though, as will be seen from section 6 , page 47 , it is 3 feet thick and hence workable in this general locality.

South of Conemaugh River, well up toward the head of Clapboard Run, the coal is worked in a small way at the present time. It is 2 feet 10 inches thick at the mine of Harry Wissinger, and this indicates that its thickness south of the river is much the same as that to the north, near Conemaugh depot. A few old openings on the bed were also noticed near the mouth of Clapboard Run. On Peggys Run is located Franklin No. 1 mine of the Cambria Steel Company. In the eastern part of Johnstown, on the Frankstown road, the coal 
is opened at a few mines, the workings of at least one of which extend through the hill and come out on the Dale road leading to Walnut Grove. In Dale the coal has been opened by numerous private individuals and .companies; and the workings extend eastward to Walnut Grove and well up to the head of Solomons .Run. The more important mines and banks are shown on Plate I, and the character of the coal bed will be outlined subsequently. (See pp. 54-56.) In the hill between Dale and Moxhom and on Sams Run east of Moxhom the coal is very thick (see sections 11, 12, and 13, below) and is worked by the Highland Coal and Coke Company and the Sunnyside Coal Company. Farther south, on Stony Creek, toward Kring, this coal bed thickens from 3 or 4 feet to as much as 6 feet in places, as near the mine of the Valley Coal and Stone Company, though that company mines only about 5 feet. (See Pl. VII, A.) In the cut on the Baltimore and Ohio Railroad north of Kring 5 feet 2 inches of coal was measured. (See section 2, p. 45.) This thick coal continues southward. The westward dips toward the Johnstown Basin carry this bed below drainage level less than a mile southeast of the Baltimore and Ohio Railroad tunnel south of Moxhom.

West of Stony Creek and 2 miles southwest of Kring, on a creck unnamed on the map, the Upper Kittanning (Cement) coal has bern opened by the Kelso Smokeless Coal Company. Here also mere than 5 feet of coal was measured. Where observed along Bens Creek in Somerset County the bed is also of workable thickness. It has been opened near the confluence of the north and south forks of Bens Creek, on the land of Elizabeth Cable, on Dalton Run, and at the reservoir dam on Dalton Run. In this locality the small seam overlying the Upper Kittanning was observed. In the region north of Bens Creek the coal is 4 feet or more in thickness. Immediately west of Johnstown the operations of the Cambria Steel Company have been pushed westward in Upper Yoder Township beyond Mill Creek, and the coal has shown no tendency to become too thin to work. The Rolling Mill mine, in which these extensive operations are in progress, is the largest mine in the area and indeed one of the largest in the State.

In the hills back of Cambria the Upper Kittanning (Cement) bed is above drainage level and has been opened in many places. At the mines of Samuel and E. W. Fuge the coal is about 3 feet in thickness. In the hills west of Morrellville the coal has been mined and may he assumed to be of workable thickness. It may be stated, therefore, that all about Johnstown the Upper Kittanning coal is workable.

Chemical character.-Analyses 5 to 10 , page 40 , indicate the composition of this coal.

The analyses show a high-carbon coal with correspondingly low volatile matter. The moisture is low, but ash and sulphur are high. 

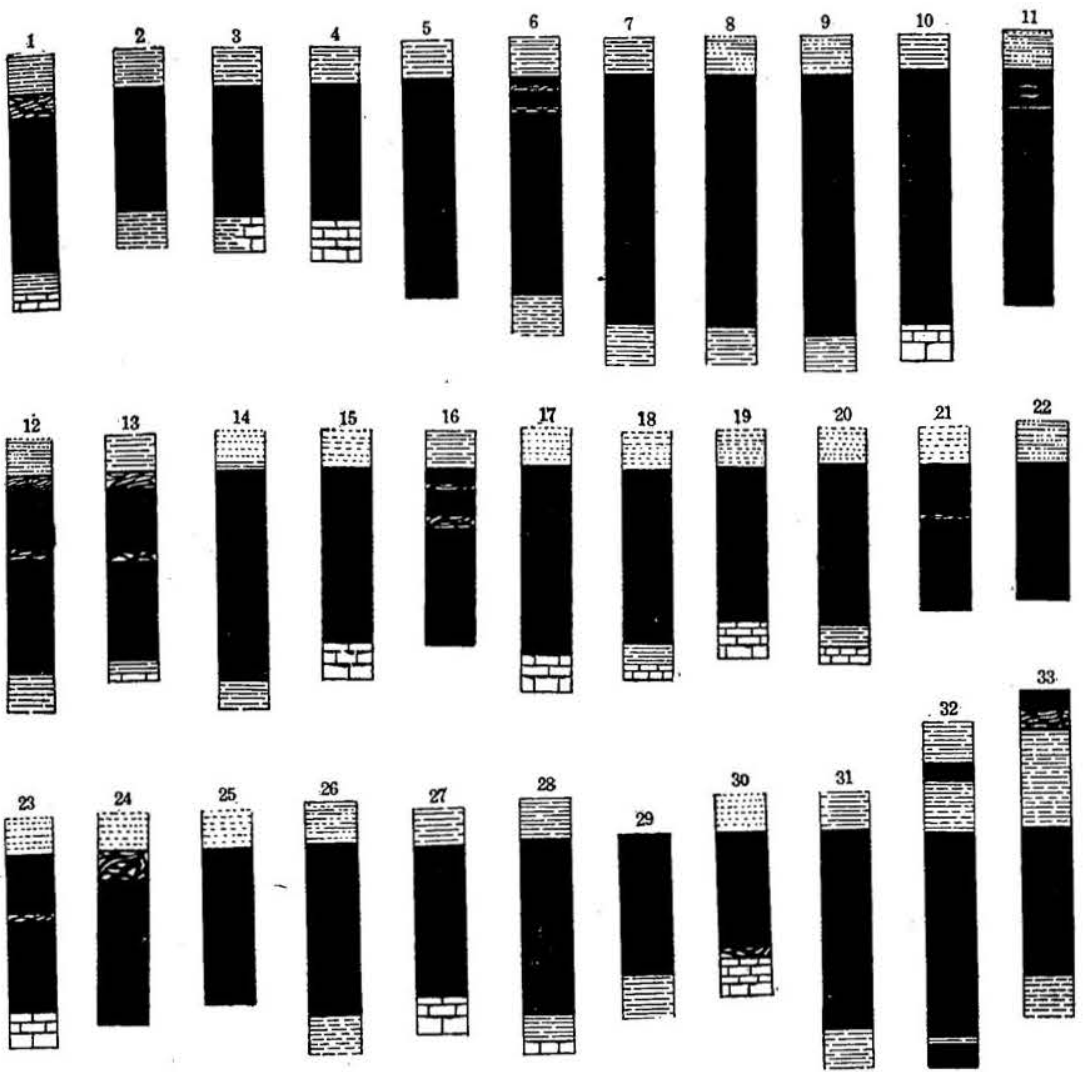

FIGURE 6.-Sections of the Upper Kittanning ( $\mathrm{C}^{\prime}$ or Cement) coal in the Johnstown district. Scale, 1 inch $=5$ feet.

1. Cambria Steel Company, Rolling Mill mine.

2. L. Prosser, north end Ten Acre Bridge.

3. E. W. Fuge, Cambria.

4. Samuel Fuge, Cambria.

5. 6 . In cut on Baltimore and Ohio Railroad, west side of Stony Creek, opposite Moxhom.

7. In cut on Baltimore and Ohio Railroad north of Kring.

8. Natural exposure, near Valley Coal and Stone Company's mine.

9. Valley Coal and Stone Company.

10. Kelso Smokeless Coal Company.

11. Highland Coal and Coke Company, Sams Run, east of Moxhom.

12, 13. Sunnyside Coal Company, between Dale and Moxhom.

14. George Heidingsfelder, head of Solomons Kun.

15. D. D. Stoll, head of Solomons Run.

16. Jacoby mine, eastern part of Dale or Walnut Grove.

17. Wertz \& Miller, Walnut Grove.

18. William Rohde, Solomons Run, east of Dale.

19. Edward Litsinger, Solomons Run, east of Dale.

20. Suppes Coal Company, Chas. H. Suppés, jr., Dale opening.

21, 22. Citizens' Coal Company, Dale mine.

23. Caddy mine.

24. Fyock's mine.

25. Jacoby mine (second opening), Dale.

26. Suppes Coal Company, Chas. H. Suppes, jr., Frankstown road opening to Dale mine. (See No. 20.)

27. Natural exposure, east of Johnstown.

28. John F. Griflith, Frankstown road, Johnstown.

29. Head of Clapboard Run.

30. Cambria Steel Company, Franklin No. 1.

31. Dalton Run, at the reservoir.

32. Dalton Run, Elizabeth Cable.

33. William McAuliff, Bens Creek, near confluence of North and South forks. 
Occurrence and physical character.-West of Johnstown, at the Cambria openings south of Conemaugh River, and north of Conemaugh River, the Upper Kittanning coal averages very nearly 3 feet in thickness; at one opening, however, it was only 2 feet 7 inches as measured. To the south along Stony Creek the bed gradually grows thicker, as indicated in sections 5, 6, 7, 8, 9, and 10 (fig. 6). Is much as 6 feet of coal was reported in places and several measurements of 5 feet were made. (See fig. 6.) The bony character of the upper 8 inches is indicated in section 6 , and as a rule the upper 8 to 12 inches has to be discarded. On Sams Run, east of Moxhom, and between Dale and Moxhom, according to observations made by F. B. Peck, the coal is between $3 \frac{1}{2}$ and 4 feet thick, generally with a few inches of bone (discarded in mining) at the top and a smill bony streak about midway between the roof and floor. At Dale and on Solomons Run the bed is usually made up of good solid coal, varying in thickness from nearly 3 feet to more than 4 feet, here and there with a bony streak near the middle and in many places with a few inches of bone at the top. On Peggys Run and in the exposures along the Pennsylvania Railroad the coal is not 3 feet thick and in places is less than $2 \frac{1}{2}$ feet thick. In Upper Yoder Township the coal ranges from 3 to 4 feet in thickness, often with one or two smaller coals above.

As a rule the coal of this bed is a good clean product, generally uniform throughout. In a few of the mines the upper foot of coil is reported soft and the lower foot harder than the average. The roof of the coal is either very dense shale or else sandy shale or sandstone and gives no trouble whatsoever. The floor is usually a few inches of firm shale or clay closely underlain by the Johnstown "cement" bed. This cement bed locally underlies the coal directly. (See Pl. VII, A.) The coal bed is uniform in thickness and few rolls are reported. Clay veins are, however, numerous and in places are very annoying. Considerable trouble is often caused by gas, which necessitates the use of safety lamps.

MIDDLE KITTANNING COAL.

In considering the stratigraphy of the different members of the Allegheny formation the presence of two small coals between the Upper and Lower Kittanning beds was pointed out (p. 26). The lower of these coals is regarded as the equivalent of the Middle Kittanning (C) coal in the Johnstown district. South of the tunnel on the Baltimore and Ohio Railroad going to Kring the distance from the base of the Upper Kittanning (Cement) bed to this coal is 32 feet (section 2, p. 45); the coal here is only $7 \frac{1}{2}$ inches thick. South of Kernville, near the Eighth Ward mine of the Citizens Coal Company, this coal is 11 inches thick and is about 43 feet 
below the base of the Upper Kittanning bed (section 4, p. 46). Along the Pennsylvania Railroad near Conemaugh depot the interval between the Cement bed and the Middle Kittanning coal is about the same-namely, 45 to 50 feet-but the coal here is only $10 \frac{1}{2}$ inches thick (section 7, p. 47). At these different places the Middle Kittanning coal is not of workable thickness, and as a rule it can not be considered workable in this district. It is fairly persistent, however, and hence serves as an additional check on the identity of the beds both above and below it. It has been opened at Coopersdale, at the brick plant of A. J. Haws \& Sons (Iimited), where it is about 25 feet above the Lower Kittanning coal and shows a thickness of 30 inches, with more concealed. It is also said to be of workable thickness at the head of Solomons Run. From what is known about it at present it can not be classed among the commercial coals of the district.

LOWER KITTANNING COAL.

Name and position.--The next lower important coal in the Allegheny formation is the Lower Kittanning coal. It is also known as the Miller or B bed in and near Johnstown. Its position below the Upper Kittanning (Cement) bed can be obtained by direct measurement at only a very few points in the Johnstown district, as most of the operations on it are conducted either by slope or incline. At the foot of the hill ascending from Kernville to Grandview Cemetery, Johnstown, the interval was reported to be 98 feet, and where hand leveled on Stony Creek south of the quadrangle it was just 100 feet. Near the Ingleside Coal Company's mine it was reported to be 86 feet. Near the Franklin mines of the Cambria Coal Company the interval between the Upper and Lower Kittanning beds was ascertained by means of a bore hole to be 90 feet. It may therefore be safely assumed that the Lower Kittanning will be found 85 to 100 feet below the Upper Kittanning (Cement) bed.

Extent and development.-Immediately about Johnstown the Lower Kittanning coal is near to or below drainage level and the mines working the coal are either slopes or shafts. North of Conemaugh River and just at the western edge of Coopersdale the rise of the measures approaching Laurel Ridge brings the coal above drainage, and it is worked by A. J. Haws \& Sons (Limited) at their brick plant. The under clay is also mined in connection with the coal. To the north on Laurel Run the coal has been opened in a small way by John Adams. East of the Haws mine the coal disappears below drainage level and does not reappear until it reaches a point just east of Conemaugh depot, where it is worked by the Keystone Coal and Coke Company. From this point as far to the east as South Fork it is above drainage level throughout nearly the entire course of 
Conemaugh River, varying of course in elevation above the river, owing to the Ebensburg anticline and the circuitous course of the stream.

South of Conemaugh River what is possibly the Lower Kittanning coal is worked at present by J. L. Custer well up on Clapboard Run. It has been worked near the mouth of the run by the Argyle Coal Company, but considerable difficulty was experienced owing to the irregularities in the bed, which ultimately led to the abandonment of operations. A short distance away, on Peggys Run, the Cambria Steel Company has opened its Franklin No. 2 mine. In this mine (No. 48, Pl. I) much difficulty has been experienced and much expensive dead work required owing to the irregularities in the coal. (See pp. 59, 60.) In the city of Johnstown the Citizens' Coal Company has a slope to this coal bed near the Adams Street Schoolhouse, and in Kernville the coal is worked by W. J. Williams. The coal is above drainage level for a short distance on Solomons Run, coming up just at the mouth of Falls Run. To the south along Stony Creek the coal appears above drainage level near Kring, and it is worked farther south on the east side of the creek by the Ingleside Coal Company. In the suburbs west of Johnstown-that is, at Morrellville and on St. Clair Run-the coal is worked by W. J. Williams and by Robertson \& Griffith. Thus the total number of mines on this bed in this region is about ten.

Chemical character.-Analyses of this coal (Nos. 11 to 14, pp. 40-41) give an idea of its composition in the Johnstown Basin.

Like the coals already considered, the Lower Kittanning (Miller) coal in the Johnstown district is a high-carbon coal low in volatile matter and moisture. The ash and sulphur show considerable variation, but this may be accounted for partly by the fact that the samples were collected at scattered localities. The ash and sulphur seem to be much in excess of these constituents in coals from the South Fork district. As a steam coal the Lower Kittanning ranks very high; the engines on the Pennsylvania Railroad are supplied in part with it from one of the mines along the line. The coal is also coked at Franklin by the Cambria Steel Company in by-product ovens for use in the company's steel plant near Johnstown. It gives satisfactory results but has to be washed before coking, thereby adding to the cost of the product. Even with this additional item of cost it is found cheaper to coke this coal on the ground than to buy coke of better quality from the Connellsville region.

Occurrence and physical character.-The thickness of the Lower Kittanning (Miller) coal in the Johnstown district is shown in figure 7; it ranges from $3 \frac{1}{2}$ to 4 feet, the latter figure probably being a maximum for the Johnstown Basin. Except along Clapboard and Peggys 
runs and near Franklin, the coal is on the whole regular; its floor rolls and here and there the coal is cut down to 2 feet, but rarely to less than this. Clay veins are generally absent and where present are small. In and about Johnstown, less than a foot below the base of the main bench and separated from it by shale, there is commonly a small coal, which varies from 7 to 24 inches, the latter measurement being made at the mine of the Somerset and Cambria Coal Company's opening on Stony Creek, near Foustwell. Below the lower coal (or in its absence below the main bench) occurs a light to dark drab plastic clay, ranging from 3 to 6 feet in thickness. It was observed that where the clay was at a maximum the coal appeared in a single bench, with the lower part bony; but it can not be stated that this condition is the usual one. The clay is of great importance near Johnstown. (See pp. 117-118.) The coal itself is in general entirely
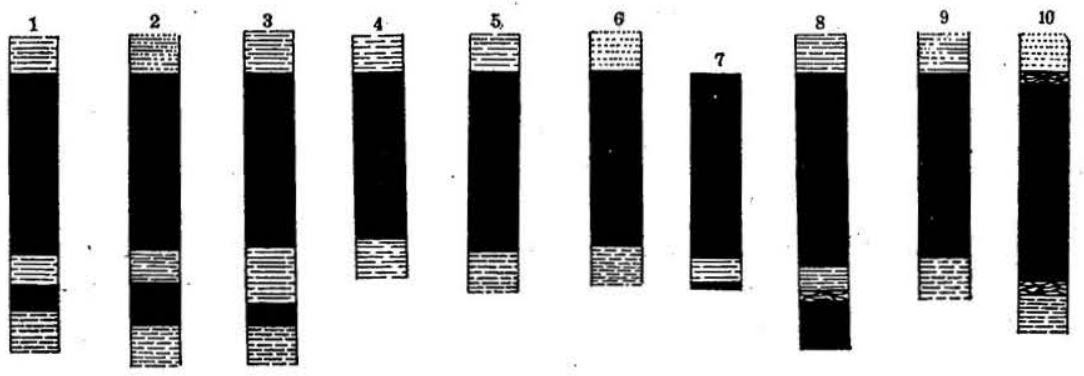

FIGURE 7.--Sections of the Lower Kittanning (Miller or B) coal in the Johnstown district. Scale, 1 inch $=5$ feet.

1. John Adams, Laurel Run.

2. A. J. Haws \& Sons, Coopersdale mine.

3. A. J. Haws \& Sons, shaft at brick plant.

4. W. J. Williams, Kernville.

5. Citizens' Coal Company, Green Hill mine.

6. Cambria Steel Company, Franklin No. 2.

7. Cambria Steel Company, Franklin No. 2, outlet on Clapboard Run.

8. Keystone Coal and Coke Company, Conemaugh slope.

9. Ingleside Coal Company.

10. Robertson \& Griffth, St. Clair Run.

free from partings and is uniform from roof to floor. The roof is massive sandstone, tough shale, or sandy shale, requiring little or no timbering, and there is no draw slate reported.

At Franklin and on Clapboard Run, on the other hand, the Lower Kittanning coal is erratic, and much difficulty has been experienced in mining on account of the irregular character of the floor. These irregularities are termed faults by the miners, but they are not faults in the geologic sense. The coal in this locality may be 6 feet thick in one place and only 15 inches thick a few feet away, and over small areas it is completely absent. It is believed that this singular 
occurrence is due to peculiar conditions of sedimentation during or subsequent to its original deposition in this locality, and not to subsequent movement, and that the trouble will be found to be only local and will disappear to the south. In confirmation of this belief may be cited two drill holes, one on the Frankstown road and the other near the head of Peggys Run, in which the Lower Kittanning coal is normally developed. So far as known, the coals above the Lower Kittanning (Miller) are normal in their occurrence; if the cause for the erratic conditions in the Lower Kittanning were regional, the Upper Kittanning (Cement) coal, which is worked at higher levels in the same hills, would probably be irregular likewise. The slight folds or rolls in the structure observed along the Pennsylvania Railroad near East Conemaugh are considered to have had nothing to do with the peculiar conditions just described. These irregularities have led to much expensive dead work near Franklin and have caused the abandonment of large operations on Clapboard Run.

\section{LOWER ALLEGHENY COALS.}

Coals lower than the Lower Kittanning and yet in the Allegheny formation are exposed in this district. At Coopersdale the top of the Pottsville formation appears at road level just west of the brick plant of A. J. Haws \& Sons (Limited). Just above, two small coal beds, each measuring less than $2 \frac{1}{2}$ feet, are exposed, separated by about 10 feet of dark shale. The section is given on page 23. These coals probably correspond to the Brookville (A) and Clarion $\left(\mathrm{A}^{\prime}\right)$ of the Allegheny Valley. One of these, probably the lower (Brookville), is exposed on Clapboard Run. The Lower Kittanning seam has been opened along this run, and about 70 feet below it a coal has been worked which is considered the Brookville or a coal very close to it. Two sections of this coal are as follows:

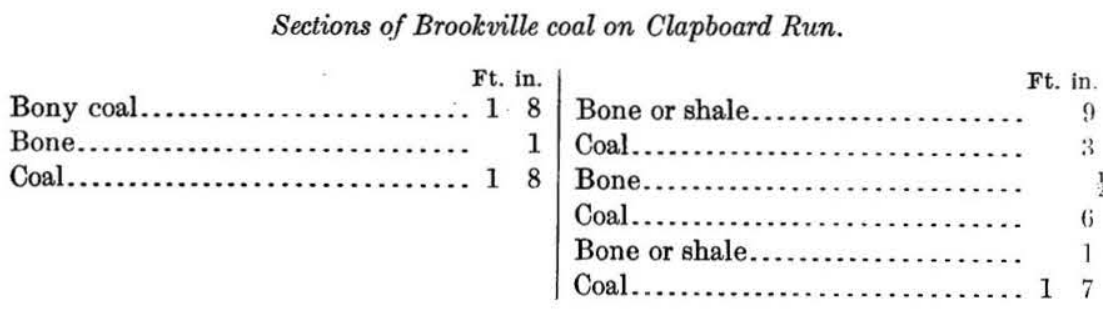

These sections are very similar, showing an upper bench from $1 \leqslant 1$ to 20 inches in thickness, mostly of bone and of no value, and a lower: bench 19 or 20 inches thick. The coal has no value along this run.

South of the quadrangle, between the mouth of Paint Creek and Foustwell, the lower part of the Allegheny, together with the whole 
of the Pottsville and a large part of the Mauch Chunk formation, is brought above drainage level on the flanks of the Ebensburg or Viaduct anticline. The section on page 27 shows a coal 10 to 15 feet above the massive sandstone at the top of the Pottsville and separated from it by shale and sandstone. It is quite possible that this may be the Clarion coal. At least it is one of the Brookville-Clarion coal group. (See fig. 8.)

POTTSVILLE COALS.

The Pottsville formation lies below the Allegheny formation and, as indicated on page 28 , consists of an upper and a lower sandstone member with an intervening shale member. This shale in many places carries a coal known as the Mercer. The

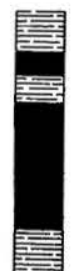

FIGURE 8.-Section of the Clarion $\left(\mathbf{A}^{\prime}\right)$ coal along Baltimore and Ohio Railroad near southern edge of Johnstown quadrangle. Scale, 1 inch $=5$ feet coal appearing between the tipple of the Ingleside Coal Company and Kring, on Stony Creek south of Johnstown, is considered to belong in the Mercer coal group. The section is as follows (see also fig. 2):

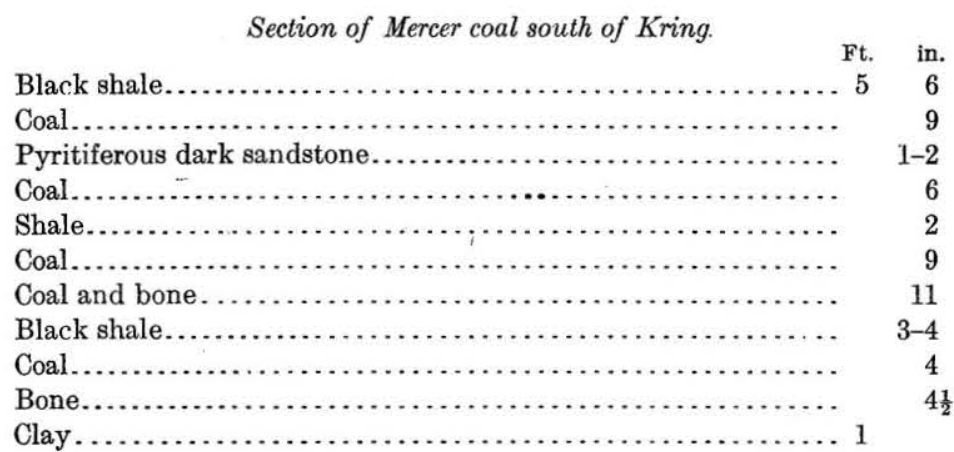

The coal is so badly broken that it can not be considered among the workable beds of the district.

Near Sheridan the Mercer coal is about a foot thick. (See p. 119.)

SOUTH FORK-MINERAL POINT DISTRICT.

EXTENT.

In the South Fork-Mineral Point district will be included all the coal occurrences between, in, and near the two towns named. The mining operations extend from Ehrenfeld on the east to the point where Conemaugh River makes a sharp bend to the south, about 2 miles west of Mineral Point. Operations are conducted on both sides of the river. The openings are confined to the immediate river valley, but the workings in many of the larger mines are very extensive and have been pushed back into the hills a long distance from the river. 


\section{GEOLOGIC POSITION OF COALS.}

The three formations which are of economic interest in the district are the Conemaugh, Allegheny, and Pottsville. The dips near South Fork are steep and the rock exposures are too imperfect to permit complete and detailed sections. North and south of Conemaugh River, however, diamond-drill holes have been put down and the records have apparently been carefully kept. Opportunity was afforded also for a measurement of the rocks in the shaft of the Pennsylvania, Beech Creek, and Eastern Coal Company near New Germany. A very clear idea, therefore, of the rocks as far down in the section as the Lower Kittanning (Miller) coal has been obtained.

On South Fork of Conemaugh River, near the northernmost cottage of the group near the old dam site, the interval between the Upper Freeport and Lower Kittanning coals is 206 feet. In the shaft at New Germany the interval between the two coals is 145 feet, a decrease to the north of 61 feet. It is known that this decrease in the interval takes place within a distance of $4 \frac{1}{2}$ miles, and it is possible that it may occur within a shorter distance.

\section{CONEMAUGH COALS.}

COAL NEAR SUMMERHILL.

Northwest of Summerhill, at an elevation of 1,800 feet, a coal has been opened by the side of the public road. It is reported to be exactly 300 feet above the Upper Freeport (Lemon or E) coal. The openings have entirely fallen in and no opportunity was afforded to measure the thickness or ascertain the character of the coal. The information was received that about 40 acres of territory had been worked out and that the coal was 4 feet thick. A measurement of the thickness of the part of the coal exposed along the roadside fully corroborates this information.

This occurrence is probably that described by Platt under the heading "Brown's mine, near Summerhill." Platt's description is as follows: ${ }^{a}$

Northeast of the outcrop [of the E coal?] the hill rises steadily for 250 feet, and neitr the top Mr. Brown opened up a bed of coal unlike, both in character and in position geologically, any other coal thus far known in Cambria County. It overlies the Upper Freeport bed (E) certainly by as much as 200 feet; but the intervening measures are concealed, and their character is therefore almost wholly unknown.

The bed has very little cover and is irregular and uneven, both roof and floor undergoing frequent changes, sometimes within a few yards. Moreover, the thickness of the bed has been very seriously affected by "horsebacks" and "clay veins," the coul varying in width all the way from 4 feet to as many inches.

Two drifts were started in on the bed at the outcrop; one gangway is driven northwest and the other northeast. In both entries there is a sharp rise, that to the northeast being due to a local roll in the rocks of tolerably wide sweep.

$a$ Second Geol. Survey Pennsylvania, Rept. H2, 1877, pp. 38-40. 
The following measurements of the bed, made in the northeast gangway, will serve to give a clearer expression to the actual condition of things:

Section made near mouth of mine.

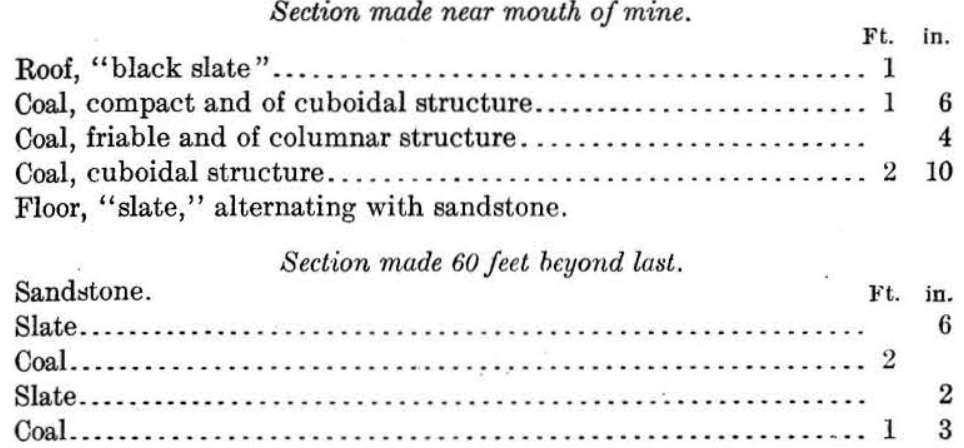

Between these two measurements a "clay vein" intervenes, cutting out the coal almost entirely for a short distance. The bed then resumes its full height as given above, but diminishes steadily in going northeast, until at the end of the entry the coal is no longer of workable size, as follows:

Roof, sandstone.
Coal $\ldots \ldots \ldots \ldots \ldots \ldots \ldots \ldots \ldots \ldots \ldots \ldots \ldots \ldots \ldots \ldots \ldots \ldots \ldots$
6

Sandstone floor.

At this point operations were brought to a close.

In the northwest mine the coal attains its greatest thickness, but is everywhere slaty and poor; it shows, however, throughout, the same horizontal crystallization already noted in connection with the other mine. The northwest entry was driven in several hundred yards, but with practically the same results as attended the operations elsewhere. These continued troubles naturally led to the abandonment of the mines.

The bed is represented only in the tops of the highest hills and covers a very limited area. The rise in the rocks carries it into the air a short distance west of Brown's openings, and east of the synclinal axis it is not known to occur.

Considering the geological horizon of the bed, together with the slaty character of the coal from it, it is apparent that this is one of the seams of the Barren Measures, of which there are several, usually thin and unimportant, but here, and confined perhaps to this immediate territory, of abnormal thickness and width.

The bed also undergoes such marked changes in point of character that no one specimen would fairly represent the average run of the mine. In the main, however, the coal is poor, being heavily loaded with earthy matter and other impurities. But along the center of the bed ranges not infrequently a narrow belt of soft, bright, rich clean coal, the limits of which are clearly defined both above and below by benches of smooth, tough, slaty coal.

Two analyses of the coal were therefore made of specimens selected and forwarded to Harrisburg by the owners of the property, the Messrs. Brown, of Summerhill. The first analysis represents the small bench of soft friable coal, and reads as follows (D. McCreath):

Water at $225^{\circ}$

Volatile matter

19. 155

Fixed carbon.

Sulphur

Ash 9. 405 


\section{MINERAL RESOURCES OF JOHNSTOWN, PA., AND VICINITY.}

Coke, per cent, 80.025; color of ash, gray. The coal is bright, tender, and seamed with charcoal and pyrites.

The other analysis may be said to represent the condition of the greater portion of the bed. The large percentage of ash, nearly one-fifth of the whole, gives to this coal its firmness and compactness and also its slightly conchoidal fracture and dull luster, but at the same time it ruins the bed totally for all practical purposes. The analysis also shows that this cannel slate is more sulphurous than the bench of soft coal in the center of the bed. The analysis is as follows (D. McCreath):

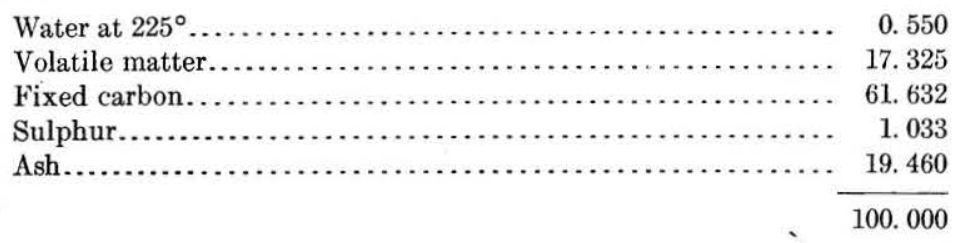

Coke, per cent, 82.125 ; color of ash, gray. The coal is exceedingly compact, has a dull, resinous luster generally, but carries seams of bright crystalline coal.

GALLITZIN COAL.

South of South Fork a coal appears in the sections about 115 fret above the Upper Freeport (Lemon or E) bed. From its interval this is probably the representative of the Gallitzin bed. It is not workable, as it is rarely more than a foot thick. North of South Fork this coal is about 65 feet above the Upper Freeport coal. Another coal, possibly the Mahoning, appears below it in the section; this likewise is not workable near South Fork.

\section{ALLEGHENY COALS}

Four coals have been worked in the Allegheny formation in the South Fork-Mineral Point district. They are (1) the Upper Freeport or E coal, which is known near South Fork and also along the eastern margin of the Wilmore Basin as the Lemon coal; (2) the Upper Kittanning or Cement coal; (3) the Lower Kittanning, Miller, or White Ash coal; and (4) the Brookville, usually referred to as the Dirty A coal. The first three are of greatest importance in this district.

UPPER FREEPORT COAL.

Name and position.-As stated above, the Upper Freeport coal is known at South Fork as the Lemon coal. It is also sometimes called the $\mathrm{E}$ bed, having been so termed by the geologists of the Second Geological Survey of Pennsylvania. It is also often referred to as the Four-foot coal. The position of this coal at the top of the Allegheny and its relations to the lower Allegheny coals are shown in figure 2. Its position with reference to the Mahoning sandstone in the South Fork district is indicated in the following section measured at Ehrenfeld: 
Section of Upper Freeport (Lemon) coal and associated beds at Ehrenfeld, Pa.

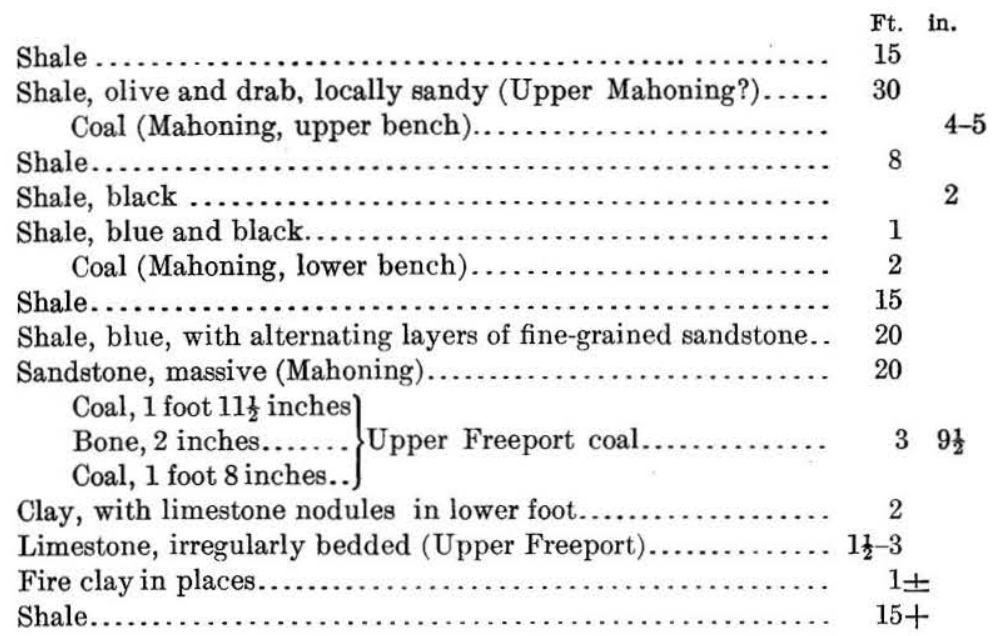

Extent and development.-The Upper Freeport coal appears above drainage level just east of Ehrenfeld, and has been opened at railroad level by the Pennsylvania, Beech Creek, and Eastern Coal Company at its No. 8 opening. Not far to the west, but higher in the hill owing to the rapid rise of the beds westward, is located mine No. 6 of the same company. This mine was not being worked in the summer of 1906, at the time of visit. West of Mineral Point this coal is present in the hills bordering Conemaugh River, but at varying distances from it. (See Pl. I.) It has been opened in a small way in one or two places, but where seen the openings had fallen in.

South of Conemaugh River it has been worked in and near South Fork by the South Fork Mining Company, and on the west side of South Fork of the Conemaugh by O. M. and H. C. Stineman. It is also present in the hills along the south side of the river, but it has been hardly touched there up to the present time.

Chemical character.-Analysis No. 3, page 40, shows the character of this coal near South Fork. It compares favorably with the other coals in the Johnstown quadrangle, and the analysis shows the normal high carbon content, with low volatile combustible matter. Moisture and ash are also low, but sulphur is high. The product from this coal bed is used chiefly for steaming purposes. It is also coked in beehive ovens at Cresson, Gallitzin, and Bennington with satisfactory results. Its composition along certain parts of the Allegheny Front-at Gallitzin, for instance - is different from that of the coal near South Fork, as the following analyses will show. The percentage of fixed carbon is lower and that of volatile matter higher in the Ebensburg region

$69516^{\circ}-$ Bull. $447-11-5$ 
than on the west side of the basin at South Fork. The coal collected at Sonman, Puritan, and Dunlo, however, is very much the same in composition as that near South Fork and Johnstown.

Analyses of Upper Freeport coal in Ebensburg quadrangle. a

\begin{tabular}{|c|c|c|c|c|c|c|c|}
\hline & 1. & 2. & 3. & 4. & 5. & 6. & 7. \\
\hline 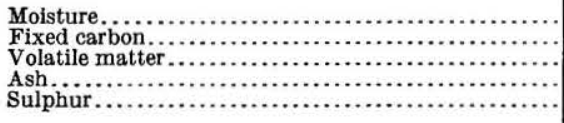 & $\begin{array}{r}0.52 \\
66.00 \\
26.59 \\
6.89 \\
1.21\end{array}$ & $\begin{array}{r}0.63 \\
64.43 \\
27.92 \\
7.02 \\
.94\end{array}$ & $\begin{array}{r}0.41 \\
74.71 \\
19.41 \\
5.47 \\
1.38\end{array}$ & $\begin{array}{r}1.41 \\
71.26 \\
20.05 \\
7.28 \\
3.34\end{array}$ & $\begin{array}{r}0.43 \\
72.89 \\
17.77 \\
8.91 \\
1.83\end{array}$ & $\begin{array}{r}0.47 \\
74.17 \\
18.44 \\
6.92 \\
1.71\end{array}$ & $\begin{array}{r}0 . .41 \\
73.17 \\
17.83 \\
8.59 \\
1.53\end{array}$ \\
\hline
\end{tabular}

a Ebensburg folio (No. 133), Geol. Atlas U. S., U. S. Geol. Survey, 1905, p. 9. The samples whose analyses are given above were collected by Charles Butts.

1, 2. Pennsylvania, Beech Creek, and Eastern Coal Company, Gallitzin. W. T. Schaller, analyst.

3. Shoemaker Coal Company, Sonman. W. T. Schaller, analyst.

4. G. Pearse \& Sons, Puritan. W. T. Schaller, analyst.

5, 6, 7. Mountain Coal Company, Dunlo. Analysis made at Metallurgical Laboratory, Pittsburg, Pa.

Occurrence and physical character.-The Upper Freeport coal about South Fork may occur in either two or three benches, of which only
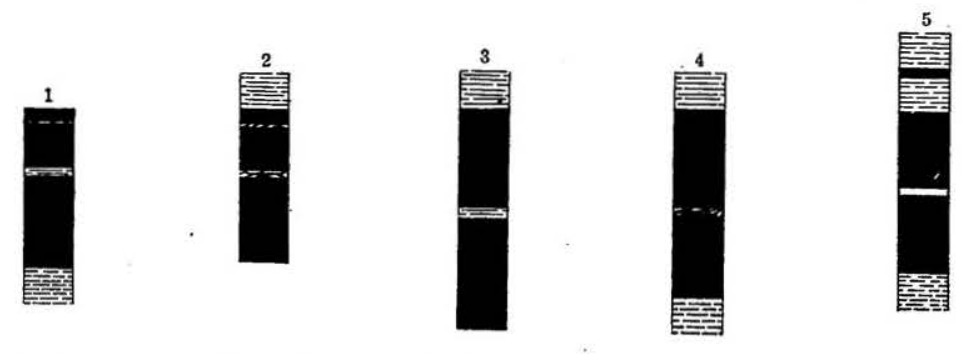

Figure 9.-Sections of the Upper Freeport ( $E$ or Lemon) coal near South Fork. Scale, 1 inch $=5$ feet.

1, O. M. Stineman No. 3; 2, H. C. Stineman No. 5; 3, Pennsylvania, Beech Creek and Eastern Coal Company No. 8; 4, natural exposure in railroad cut at Ehrenfeld; 5, South Fork Coal Mining Company No. 2.
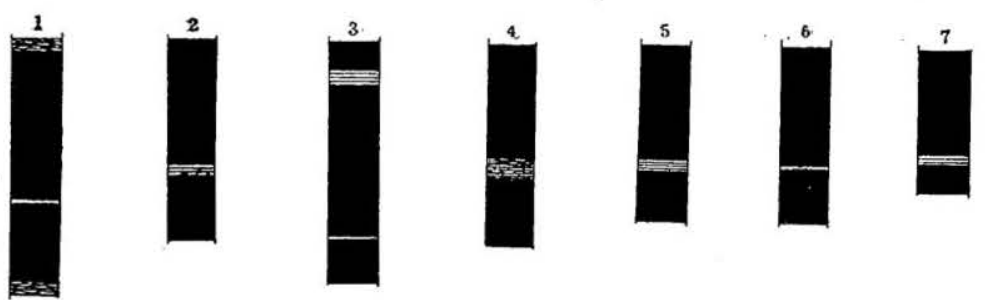

FIgURE 10.-Sections of the Upper Freeport coal along the southeastern margin of the Wilmore Basin (after Butts). Scale, 1 inch $=5$ feet.

1, Webster No. 11 mine, southeast of Gallitzin, Pa.; 2, Shoemaker mine, Sonman; 3, Hopfer's mine, Trout Run; 4, George Pearse \& Sons, Puritan; 5, Beaverdam Run, near Pavia road; 6, Logan Coal Conpany, Beaverdale; 7, Dunlo.

the two lower are workable, and in this respect it differs essentially. from the same coal about Johnstown. At Ehrenfeld and at opening No. 8 of the Pennsylvania, Beech Creek, and Eastern Coal Company, on the opposite side of Conemaugh River, only two benches were observed, and the upper bench is for the most part very much thicker than the corresponding middle bench at places where three are 
present. The upper of the workable benches ranges in thickness from 1 foot to 2 feet and the lower bench from $1 \frac{1}{2}$ to 2 feet. The bone or shale between the two main benches ranges from half an inch to 2 inches. It is very persistent in this district and is usually present also in this bed along the southeast margin of the Wilmore Basin. Figures 9 and 10 show the general similarity of this coal bed on both sides of the Wilmore Basin.

LOWER FREEPORT COAL.

The next lower coal in the South Fork district is the Lower Freeport coal, which lies from 40 to 50 feet below the Upper Freeport coal. It is persistent and is shown in most of the diamond-drill records, but it has not been developed in this district. Locally it is of workable thickness; in some of the well records it measures as much as $2 \frac{1}{2}$ feet solid coal with no partings; in others it consists of two benches separated by a thin binder. The two benches taken together would constitute a workable bed. In most of the sections studied it is so badly broken up or so thin as to be of no value; and it therefore can not be classed among the commercial coals in this district at present.

UPPER KITTANNING (CEMENT) COAL.

Name and position.-The next lower coal-the Upper Kittanning (Cement) bed-is an important coal near South Fork. It corresponds to the same bed about Johnstown, though it is not at this time so important as the coal in that district. It occurs nearly midway between the Upper Freeport (Lemon or E) coal and the Lower Kittanning (Miller) bed. North of Conemaugh River, therefore, where the interval between these two coals is only 145 feet (as near New Germany), it occurs about 67 feet below the Upper Freeport coal and about 75 feet above the Lower Kittanning. South of the river, where the interval between the Upper Freeport and Lower Kittanning is approximately 200 feet, it is again about midway between the two, its distance below the former and above the latter ranging from 92 to 105 feet.

Extent and development.-The Upper Kittanning is worked for local supply in the town of South Fork by Robert A. Giles and Charles Hutzel. Other (abandoned) banks in the town were observed. West of the town and on the west side of South Fork it is worked on a considerable scale by H. C. and O. M. Stineman. The coal is present in the hills westward to Mineral Point and beyond. Near Mineral Point two small mines on this coal bed belong to $\mathrm{H}$. W. Gillan. (See Pl. IV, B.)

Chemical character.-Analysis No. 5, page 40, indicates the composition of this coal in South Fork. The coal is bright and lustrous 
and the analysis shows it to be on a par with the corresponding coal in the Johnstown district. Both its ash and sulphur average below those of the coal in that district, but in other respects the analyses are very similar.

To the east, in the Ebensburg quadrangle, this coal is locally workable and has been opened and worked by G. Pearse \& Sons at Puritan, on Trout Run. The composition of the coal here, as shown in the table below, is about the same as it is farther west, about South Fork; but analyses of the two samples collected in the same mine show considerable divergence.

Analyses of Upper Kittanning coal at Puritan.

[W. T. Schaller, analyst.]

\begin{tabular}{|c|c|c|}
\hline & 1. & 2. \\
\hline 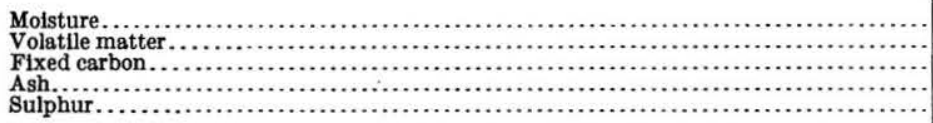 & $\begin{array}{r}1.70 \\
19.28 \\
71.19 \\
7.83 \\
1.60\end{array}$ & $\begin{array}{r}0.52 \\
22.00 \\
67.49 \\
9.99 \\
3.47\end{array}$ \\
\hline
\end{tabular}

Occurrence and physical character.-In thickness the coal ranges from 3 to $3 \frac{1}{2}$ feet, usually without any partings, and has a hard shale roof which gives no trouble. There is in places a few inches of bone
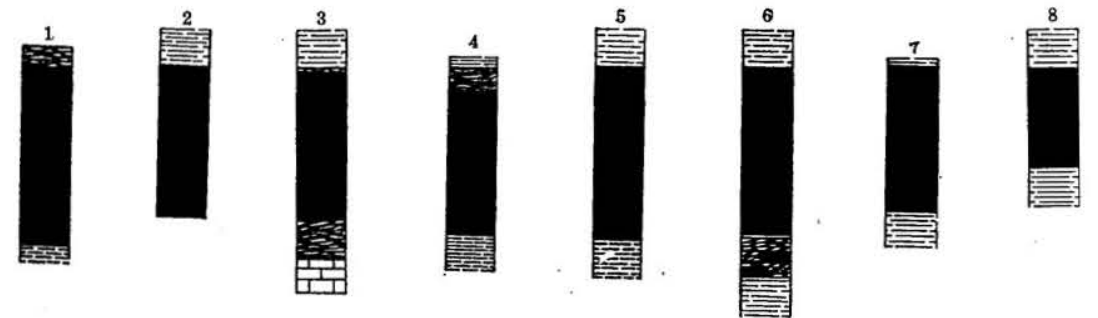

FIGURE 11.-Sections of the Upper Kittanning (Cement or $\mathrm{C}^{\prime}$ ) coal in the South Fork-Mineral Point district. Scale, 1 inch $=5$ feet.

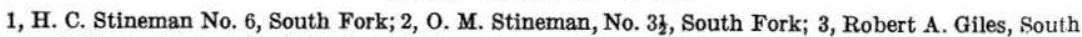
Fork; 4, Charles Hutzel, South Fork; 5, Old opening, southern part of South Fork; 6, 7, H. W. Gillan, near Mineral Point; 8, Salt Lick Run.

at the top, which is discarded in mining. The lower part of the coal is locally bony. Below this, and in its absence directly below the coal, there is a band of clay, ranging from a few inches to more than 2 feet. Below the clay, or just below the coal itself, is found a bed of limestone or cement rock-the Johnstown limestone membermeasuring in places as much as 4 feet.

Figure 11 indicates graphically what has been outlined above. In the area to the east the coal is locally workable, and where exploited by G. Pearse \& Sons, on Trout Run, on the east side of the basin, 
in the Ebensburg quadrangle, its thickness is very much the same as near South Fork. At Bennington it is 2 feet 10 inches thick; in the Sonman shaft it is 2 feet; in theYellow Run shaft 2 feet 6 inches; and in a diamond-drill hole of the Henriette Mining Company, south of Llanfair, it is 1 foot thick. On the east side of the basin, therefore, it can not be considered more than locally workable. On the west side of the basin it may be regarded as among the future important coals, both near South Fork and in the region to the south, where considerable exploratory work with the diamond drill has showed this coal to be 3 feet or more in thickness.

LOWER KITTANNING (MILLER) COAL.

Name and position.-The Lower Kittanning, Miller, B, or White Ash bed is the most important coal in the South Fork-Mineral Point district. Immediately about South Fork it lies 160 feet below the Upper Freeport bed; elsewhere it ranges from 145 to 200 feet below the Upper Freeport coal (see p. 24) and about half as much below the Upper Kittanning (Cement) bed. Its position, approximately 55 to 65 feet above the top of the Pottsville (or "conglomerate rock," as the Pottsville is popularly called), should serve to locate and identify it with little trouble in the South Fork-Mineral Point district.

Extent and development.-North of Conemaugh River the coal has been opened by the Pennsylvania, Beech Creek, and Eastern Coal Company and worked at its No. 3 and No. 5 mines, the workings in the latter being on the dip of the bed. Farther west the Priscilla Coal Company is working the same bed, and still beyond, near the Ebensburg (Viaduct) anticlinal axis, are the openings of the Keystone Coal and Coke Company, called Argyle Nos. 1 and 2 mines. There are also a few abandoned mines on the Lower Kittanning bed north of Conemaugh River, and to judge from the culm heaps at their tipples large bodies of coal have been removed from them.

South of the river and west of South Fork the workings on the Lower Kittanning coal are extensive. The mines here include collieries Nos. 2 and 4 of the Stineman Coal and Coke Company and colliery No. 1 of the Stineman Coal Mining Company. To the east and in the town itself are the workings of the South Fork Coal Mining Company. The magnitude of the coal industry at South Fork may be judged from the fact that in 1905 there were produced in these mines $1,400,000$ tons of coal, valued at $\$ 1,500,000$.

Chemical character.-Analyses Nos. 15, 16, 28, and 29 (pp.40-42) give an excellent idea of the high grade of this coal as mined near South Fork. The analyses below give an idea of its composition in the Ebensburg quadrangle, on the southeast flank of the Wilmore Basin. 
MINERAL RESOURCES OF JOHNSTOWN, PA., AND VICINITY.

Analyses of Lower Kittanning (Miller) coal in the Ebensburg quadrangle. ${ }^{a}$

[Air-dried samples; W. T. Schaller, analyst.]

\begin{tabular}{|c|c|c|c|c|c|c|c|}
\hline . & 1. & 2. & 3. & 4. & 5. & 6. & 7. \\
\hline 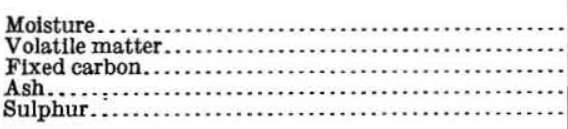 & $\begin{array}{r}0.53 \\
26.90 \\
63.52 \\
9.05 \\
1.21\end{array}$ & $\begin{array}{r}0.32 \\
21.97 \\
71.38 \\
6.33 \\
.68\end{array}$ & $\begin{array}{r}0.57 \\
23.52 \\
69.64 \\
6.27 \\
.99\end{array}$ & $\begin{array}{r}0.38 \\
19.44 \\
74.28 \\
5.90 \\
.72\end{array}$ & $\begin{array}{r}0.36 \\
20.46 \\
72.76 \\
6.42 \\
1.74\end{array}$ & $\begin{array}{r}0.35 \\
17.81 \\
74.28 \\
7.56 \\
3.14\end{array}$ & $\begin{array}{r}0.43 \\
19.41 \\
75.78 \\
4.38 \\
.76\end{array}$ \\
\hline
\end{tabular}

$a$ Ebensburg folio (No. 133), Geol. Atlas U. S., U. S. Geol. Survey, 1905, p. 9.

1. Reed \& Bradley mine, Bennington.

2, 3. Lilly Mining Company, Bear Rock Run.

4. A. C. Blowers, Bens Creek.

5, 6. Alton Coal Company, Lioydell.

7. Henriette Coal Company, near Llanfair.

i to 6 collected by Charles Butts; 7 by W. C. Phalen.

From the analyses (pp.40-42) it appears that the fixed carbon in the samples collected in the Johnstown quadrangle, near South Fork, ranges from 74 to more than 78 per cent, with volatile matter ranging from 14 to more than 16 per cent. The moisture of the samples as received at the laboratory is low, not exceeding 3.5 per cent. The samples from South Fork are notably low in sulphur and ash and show the excellent character of the Lower Kittanning (Miller) coal in this part of the Wilmore Basin. The samples collected from the Ebensburg quadrangle by Charles Butts and W. C. Phalen during the summer of 1903 were analyzed in the chemical laboratory of the Survey at Washington and not in the laboratory of the technologic branch of the Survey at St. Louis. The results of analyses are therefore not strictly comparable with the results of analyses from South Fork (pp. 40-42). The former show more diversity in composition, as would naturally be expected when the scattered places from which the samples were collected are considered. The general similarity of the results, however, is noteworthy, as is also the low content in sulphur and ash. The second sample collected from the Alton Coal Company's mine at Lloydell (No. 6, above) seems to be entirely exceptional regarding its sulphur content, and it is probable that a "sulphur ball" found its way into the sample without being suspected.

Steaming tests.-As a steam coal the Lower Kittanning (Miller) coal from the South Fork district ranks among the very best of western Pennsylvania and probably equals in steaming value any other steam coal in this part of the State. (See comparative tables, p. 37.)

In the following tables are given the results of tests on run-ofmine coal loaded under the supervision of J. S. Burrows, formerly of the Survey, collected from No. 3 mine of the Pennsylvania, Beech Creek, and Eastern Coal Company, at Ehrenfeld. One coking test, five steaming tests, and one producer-gas test were made on the car- 
load sample collected. ${ }^{a}$ A steaming test was also made on this sample mixed with coal from the Darby mine of the Darby Coal and Coke Company, at Darby, Lee County, Va., but the results of this test are not given in the bulletin cited.

The analysis of the carload sample tested is as follows (for mine samples see analyses 28 and 29 , pp. 41-42):

Analysis of carload sample of Lower Kittanning coal from South Fork-Mineral Point district.

Laboratory No................................... 2152

Air-drying loss...................................... $\quad 2.90$

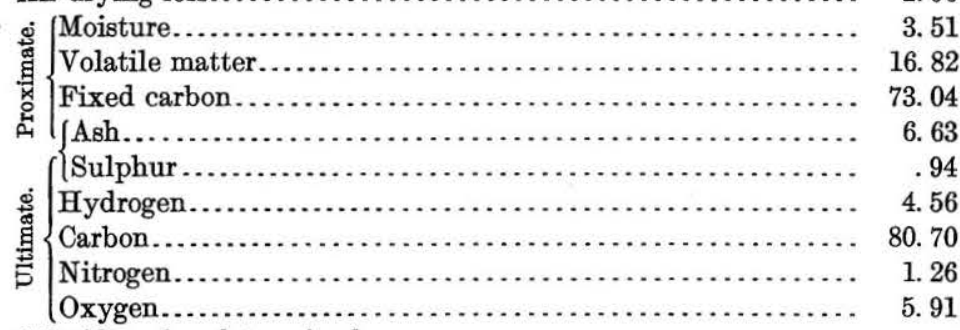

Calorific value determined:

Calories......................................... 7,933

British thermal units............................. 14, 279

The results of the steaming tests on this coal are as follows:

Steaming tests on Lower Kittanning coal from South Fork-Mineral Point district.

\begin{tabular}{|c|c|c|c|c|c|}
\hline & Test 236 . & Test 237. & Test 238. & Test 239. & Test 242. \\
\hline $\begin{array}{l}\text { Heating value of coal...B. t. u. per pound of dry coal.. } \\
\text { Force of draft: }\end{array}$ & 14,886 & 14,868 & 14,828 & 14,690 & 14,659 \\
\hline 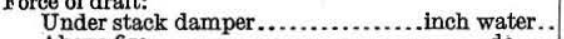 & 0.43 & 0.45 & 0.50 & 0.63 & 0.47 \\
\hline 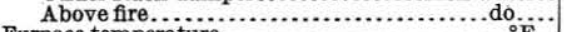 & .15 & .16 & .17 & .19 & .16 \\
\hline 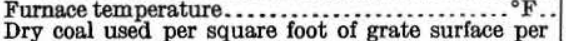 & 2,317 & 2,266 & 2,212 & ..... & 2,059 \\
\hline 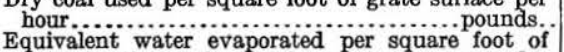 & 15.74 & 16.23 & 15.69 & 17.64 & 14.33 \\
\hline water-heating surface per hour & 2.93 & 2.96 & 2.93 & 3.08 & 2.92 \\
\hline $\begin{array}{l}\text { Percentage of rated horsepower of boiler developed... } \\
\text { Water apparently evaporated per pound of coal as }\end{array}$ & 82.0 & 83.0 & 82.1 & 86.5 & 81.9 \\
\hline 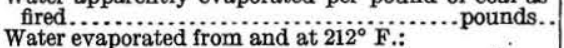 & 8.51 & 8.27 & 8.44 & 7.98 & 8.52 \\
\hline Per pound of coal as fired.............. & 10.12 & 9.85 & 10.05 & 9.52 & 10.17 \\
\hline Per pound of dry coal & 10.37 & 10.17 & 10.42 & 9.75 & 10.22 \\
\hline Per pound of combustible..................... & 11.20 & 11.02 & 11. 29 & 10.71 & 11.15 \\
\hline $\begin{array}{l}\text { Efficiency of boiler, including grate.......... per cent.. } \\
\text { Coal as fired: }\end{array}$ & 67.27 & 66.06 & 67.86 & 64.10 & 67.19 \\
\hline 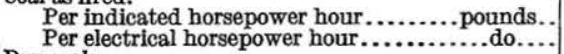 & $\begin{array}{l}2.79 \\
3.45\end{array}$ & $\begin{array}{l}2.87 \\
3.54\end{array}$ & $\begin{array}{l}2.81 \\
3.47\end{array}$ & $\begin{array}{l}2.97 \\
3.67\end{array}$ & $\begin{array}{l}2.78 \\
3.43\end{array}$ \\
\hline $\begin{array}{l}\text { Dry coal: } \\
\text { Per indicated horsepower hour........... do }\end{array}$ & 2.73 & 2.78 & 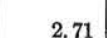 & & 27 \\
\hline Per electrical horsepower hour. & 3.37 & 3.43 & 3.35 & 3.58 & 3.41 \\
\hline Proximate analysis: & & & & & \\
\hline Moisture ............................ & 2.37 & 3.11 & 3.56 & 2.44 & 0.42 \\
\hline $\begin{array}{l}\text { Volatile matter } \\
\text { Fixed carbon.. }\end{array}$ & $\begin{array}{l}16.74 \\
74.66\end{array}$ & $\begin{array}{l}15.68 \\
74.93\end{array}$ & $\begin{array}{l}16.09 \\
73.85\end{array}$ & $\begin{array}{l}16.64 \\
73.69\end{array}$ & 17.51 \\
\hline Ash........... & 6. 23 & 6. 28 & 6.50 & 7.23 & 6.87 \\
\hline Sulphur.. & $\begin{array}{r}100.00 \\
.88\end{array}$ & $\begin{array}{r}-100.00 \\
.89\end{array}$ & $\begin{array}{r}100.00 \\
.87\end{array}$ & $\begin{array}{r}100.00 \\
1.12\end{array}$ & $\begin{array}{r}100.00 \\
1.01\end{array}$ \\
\hline
\end{tabular}

a Bull. U. S. Geol. Survey No. 290, 1906, pp. 178-181. 
Steaming tests on Lower Kittanning coal from South Fork-Mineral Point districtContinued.

\begin{tabular}{|c|c|c|c|c|c|}
\hline & Test 236. & Test 237. & Test 238 . & Test 239 . & Test 242. \\
\hline 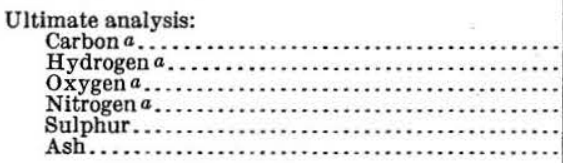 & $\begin{array}{r}84.14 \\
4.34 \\
2.93 \\
1.31 \\
.90 \\
6.38\end{array}$ & $\begin{array}{r}84.03 \\
4.35 \\
2.91 \\
1.31 \\
.92 \\
6.48\end{array}$ & $\begin{array}{r}83.81 \\
4.33 \\
2.91 \\
1.31 \\
.90 \\
6.74\end{array}$ & $\begin{array}{r}82.98 \\
4.28 \\
2.89 \\
1.29 \\
1.15 \\
7.41\end{array}$ & $\begin{array}{r}8.35 \\
4.15 \\
3.27 \\
1.32 \\
1.01 \\
6.90\end{array}$ \\
\hline & 100.00 & 100.00 & 100.00 & 100.00 & 100.00 \\
\hline
\end{tabular}

a Figured from car sample.

Test 236: Size as shipped, run of mine. Size as used, over 1 inch, 6.5 per cent; $\frac{1}{2}$ inch to 1 inch, 13.6 per cent; $\frac{1}{4}$ inch to $\frac{1}{2}$ inch, 22.4 per cent; under $\frac{1}{4}$ inch, 57.5 per cent. Duration of test, 9.88 hours. Kind of

grate, rocking.
Test 237: Size as shipped, run of mine. Size as used, over $1 \mathrm{inch,} 5.8$ per cent; $\frac{1}{2}$ inch to 1 inch, 12.3 per cent; $\frac{1}{4}$ inch to $\frac{1}{2}$ inch, 19.5 per cent; under $\frac{1}{2}$ inch, 62.4 per cent. Duration of test, 10 hours. Kind of

grate, rocking.
Test 238: Size as shipped, run of mine. Size as used, over 1 inch, 5.4 per cent; $\frac{1}{2}$ inch to 1 inch, 9.1 per cent; $\frac{1}{4}$ inch to $\frac{1}{2}$ inch, 14.9 per cent; under $\frac{1}{4}$ inch, 70.6 per cent. Duration of test, 10.02 hours. Kind of grate, rocking.,

Test 239: Size as shipped, run of mine. Size as used, over 1 inch, 4.4 per cent; $\frac{1}{2}$ inch to 1 inch, 8.8 per cent; $\downarrow$ inch to $\frac{1}{2}$ inch, 16.2 per cent; under $\frac{1}{4}$ inch, 70.6 per cent. Duration of test, 9.92 hours. Kind of

grate, rocking.
Test 242: Size as shipped, run of mine. Size as used, over $1 \mathrm{inch}, 2.0$ per cent; $\frac{1}{2}$ inch to 1 inch, 7.0 per cent; $\frac{1}{4}$ inch to $\frac{1}{2}$ inch, 14.5 per cent; under $\frac{1}{6}$ inch, 76.5 per cent. Dried coal. Duration of test, 7.88 hours. Kind of grate, plain.

The figure giving the number of pounds of water evaporated by 1 pound of dry coal from and at a temperature of $212^{\circ} \mathrm{F}$. gives the results of the coal tested so far as these relate to its commercial value, and the reader is referred to the table on page 37 for the standing of the Ehrenfeld coal among other standard steaming coals. The results of the tests, on the Ehrenfeld samples though showing a range of 9.75 to 10.42 pounds of water evaporated per pound of dry coal used, are yet, when averaged, among the very best made at the testing plant.

Coking tests.-The coal from the lower Kittanning bed near South Fork has been coked, and the results of the test on the.sample from Ehrenfeld are given below:

\section{Coking test on Lower Kittanning coal from Ehrenfeld.}

[Run of mine; finely crushed; raw; duration of test, 51 hours.]

Coal charged................................ pounds.. 10,000

Coke produced.................................... 5, 223

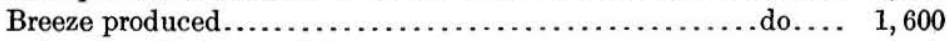

Coke produced ................................. 52.23

Breeze produced.................................. 16.00

Total percentage yield.............................. 68.23

The product was a soft, dense coke of a dull-gray color, in large and small chunks. There was a heavy black butt on the coke, and it was hard to burn. The cell structure was small. 
Analyses of coal and coke.

\begin{tabular}{|c|c|c|}
\hline & Coal. & Coke. \\
\hline 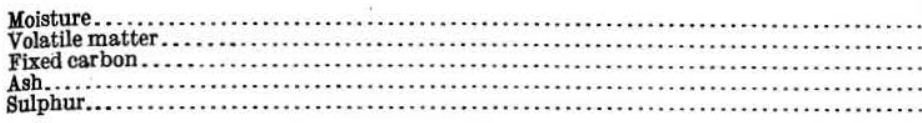 & $\begin{array}{r}3.32 \\
15.56 \\
74.29 \\
6.83 \\
1.12\end{array}$ & $\begin{array}{r}0.91 \\
2.16 \\
88.99 \\
7.94 \\
.91\end{array}$ \\
\hline
\end{tabular}

The yield of coke from this test is comparatively high, but the poor quality of the coke shows that the coal does not belong among the best coking coals of western Pennsylvania and West Virginia. Coke made by the Cambria Steel Company with coal mined from this bed about Ehrenfeld proved well adapted to metallurgical purposes. The yield also was satisfactory.

Cupola tests. ${ }^{a}$-In connection with the tests of coals made at the plant of the United States Geological Survey at St. Louis in 1904 practical melting tests were made of coke that showed any likelihood to be of value to the foundry industry. Among those tested was one made from coal collected at colliery No. 3 of the Pennsylvania, Beech Creek, and Eastern Coal Company at Ehrenfeld. The test was conducted in a 36-inch foundry cupola lent by the Whiting Foundry Equipment Company, of Chicago. The 36 -inch shell of the cupola was relined to 26 inches internal diameter. There were four horizontal tuyeres measuring 4 by 6 inches on the outside and 3 by 13 inches on the inside of the cupola, which were situated 11 inches above the sand bottom. The total tuyere area was 96 square inches, giving a ratio of 1 to 5.96 with the cupola area. A No. 6 Sturtevant fan run at 2,514 revolutions a minute furnished the blast, which was kept at about 7 ounces.

The cupola test was conducted by W. G. Ireland, and the details of the method employed are outlined in the references cited above and will not be given here. The results of the test are shown in the following table:

a Prof. Paper U. S. Geol. Survey No. 48, pt. 3, 1906, pp. 1367-1370: Bull. U. S. Geol. Survey No. 336, 1908 , pp. $48,49,50,54,57,60,63$. 
Cupola tests on Lower Kittanning (Miller) coal from Ehrenfeld.

\begin{tabular}{|c|c|c|c|c|c|c|c|c|c|c|c|c|c|c|c|c|c|c|c|c|c|c|c|c|c|}
\hline \multirow{3}{*}{\multicolumn{2}{|c|}{$\begin{array}{c}\text { Cupola } \\
\text { test } \\
\text { No. }\end{array}$}} & \multirow{3}{*}{\multicolumn{5}{|c|}{ Date. }} & \multicolumn{18}{|c|}{ Charges (pounds). } & \multirow{3}{*}{$\begin{array}{c}\text { Ratio } \\
\text { iron to } \\
\text { coke. }\end{array}$} \\
\hline & & & & & & & \multirow{2}{*}{$\begin{array}{l}\text { Coke } \\
\text { bed. }\end{array}$} & \multirow{2}{*}{$\begin{array}{l}\text { Pig } \\
\text { iron. }\end{array}$} & \multirow{2}{*}{ Scrap } & \multirow{2}{*}{ Coke } & \multirow{2}{*}{${ }_{\text {iron }}^{P i g}$} & \multirow{2}{*}{ Scrap } & \multirow{2}{*}{ Coke. } & \multirow{2}{*}{$\begin{array}{l}\text { Pig } \\
\text { iron. }\end{array}$} & \multirow{2}{*}{ Scrap. } & \multirow{2}{*}{ Coke. } & \multirow{2}{*}{$\begin{array}{l}\text { Pig } \\
\text { iron. }\end{array}$} & \multirow{2}{*}{ Scrap } & \multirow{2}{*}{ Coke. } & \multirow{2}{*}{$\begin{array}{l}\text { Pig } \\
\text { iron. }\end{array}$} & \multirow{2}{*}{ Scrap. } & \multicolumn{3}{|c|}{ Total. } & \\
\hline & & & & & & & & & & & & & & & & & & & & & & Coke. & $\begin{array}{c}\text { Pig } \\
\text { iron. }\end{array}$ & Scrap. & \\
\hline \multicolumn{2}{|c|}{$\begin{array}{r}65 \\
188\end{array}$} & \multicolumn{5}{|c|}{ 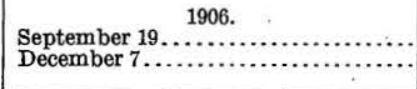 } & $\begin{array}{l}180 \\
195\end{array}$ & $\begin{array}{l}540 \\
585\end{array}$ & $\begin{array}{l}180 \\
195\end{array}$ & $\begin{array}{l}63 \\
59\end{array}$ & $\begin{array}{l}428 \\
417\end{array}$ & $\begin{array}{l}143 \\
139\end{array}$ & $\begin{array}{l}63 \\
59\end{array}$ & $\begin{array}{l}428 \\
416\end{array}$ & $\begin{array}{l}143 \\
139\end{array}$ & $\begin{array}{l}62 \\
59\end{array}$ & $\begin{array}{l}427 \\
416\end{array}$ & $\begin{array}{l}142 \\
139\end{array}$ & $\begin{array}{l}62 \\
58\end{array}$ & $\begin{array}{l}427 \\
416\end{array}$ & $\begin{array}{l}142 \\
138\end{array}$ & $\begin{array}{l}430 \\
430\end{array}$ & $\begin{array}{l}2,250 \\
2,250\end{array}$ & $\begin{array}{l}750 \\
750\end{array}$ & $\begin{array}{l}7 \\
7\end{array}$ \\
\hline \multirow[b]{3}{*}{ 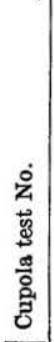 } & \multicolumn{7}{|c|}{ Analysis of coke (per cent). } & \multirow{3}{*}{\multicolumn{3}{|c|}{ 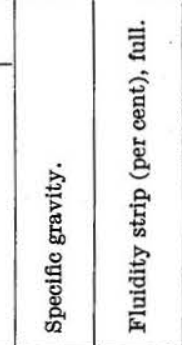 }} & \multirow{3}{*}{ 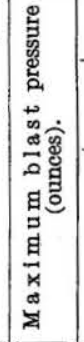 } & \multicolumn{14}{|c|}{ Record of melt. } \\
\hline & \multirow[b]{2}{*}{$\begin{array}{l}\text { d } \\
\text { 总 } \\
\text { 总 }\end{array}$} & \multirow[b]{2}{*}{ 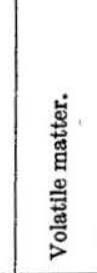 } & \multirow[b]{2}{*}{ 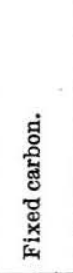 } & \multirow{2}{*}{ क्. } & \multicolumn{2}{|c|}{ Sulphur. } & & & & & & Poun & ads of ir & ron. & Melt & lting ra & ate. & $\begin{array}{l}\text { Recov } \\
\text { (poun }\end{array}$ & $\begin{array}{l}\text { zered } \\
\text { ads). }\end{array}$ & $\dot{\overrightarrow{0}}$ & Melt & ting rat & & Coke & e bed. \\
\hline & & & & & $\begin{array}{l}\text { 递 } \\
\text { 品 }\end{array}$ & $\begin{array}{l}\text { 迎 } \\
\text { 品 }\end{array}$ & 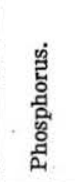 & & & & & 总 & 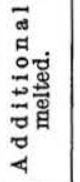 & 槑 & 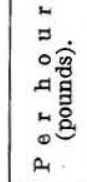 & & 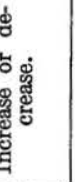 & 苂 & 递 & 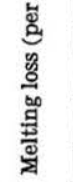 & 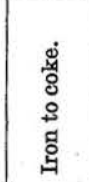 & 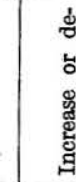 & . & 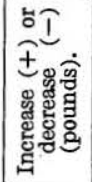 & 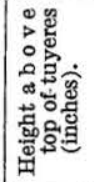 \\
\hline $\begin{array}{r}65 \\
188\end{array}$ & $\begin{array}{r}0.91 \\
.91\end{array}$ & $\begin{array}{l}2.16 \\
2.16\end{array}$ & $\begin{array}{l}88.99 \\
88.99\end{array}$ & $\begin{array}{l}7.94 \\
7.94\end{array}$ & $\begin{array}{r}0.91 \\
.91\end{array}$ & $\begin{array}{r}0.10 \\
.10\end{array}$ & $\begin{array}{r}0.0049 \\
.0049\end{array}$ & $\begin{array}{l}1.7 \\
1.7\end{array}$ & $\begin{array}{l}98 . \\
93 .\end{array}$ & .61 & $\begin{array}{l}7 \\
7\end{array}$ & $\begin{array}{l}1,939 \\
2,256\end{array}$ & $\begin{array}{l}565 \\
257\end{array}$ & $\begin{array}{l}2,504 \\
2,513\end{array}$ & $\begin{array}{l}5,181 \\
5,799\end{array}$ & \begin{tabular}{l|l}
1 & $\ldots$ \\
9 & Incr
\end{tabular} & crease. & $\begin{array}{l}228 \\
199\end{array}$ & $\begin{array}{l}81 \\
49\end{array}$ & $\begin{array}{l}9.07 \\
9.60\end{array}$ & $\begin{array}{l}7.20 \\
6.50\end{array}$ & Dec & crease. & $\cdots+15$ & 16.33 \\
\hline
\end{tabular}


Cupola tests on Lower Kittanning (Miller) coal from Ehrenfeld-Continued.

\begin{tabular}{|c|c|c|c|c|c|c|c|c|c|c|c|c|c|c|c|c|c|c|c|c|c|c|c|c|}
\hline \multirow{3}{*}{$\begin{array}{l}\text { Cu- } \\
\text { pola } \\
\text { test } \\
\text { No. }\end{array}$} & \multicolumn{9}{|c|}{ 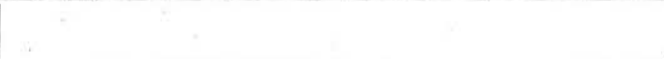 } & \multicolumn{7}{|c|}{ Record of melt-Continued. } & & \multicolumn{3}{|l|}{. } & \\
\hline & \multirow{2}{*}{\multicolumn{2}{|c|}{$\begin{array}{l}\text { Blast on } \\
\text { at- }\end{array}$}} & \multirow{2}{*}{$\begin{array}{l}\text { Iron } \\
\text { run- } \\
\text { ning. }\end{array}$} & \multicolumn{21}{|c|}{ Weight and time of each ladle of melted iron. } \\
\hline & & & & Lbs. & \multicolumn{2}{|c|}{ At- } & Lbs. & At- & Lbs. & At- & \multicolumn{2}{|c|}{ Lbs. } & At- & Lbs. & At- & Lbs. & \multicolumn{2}{|c|}{ At- } & Lbs. & At- & Lbs. & At- & Lbs. & At- \\
\hline $\begin{array}{r}65 \\
188\end{array}$ & $\begin{array}{r}11.35 \mathrm{a} \\
3.34 \mathrm{p}\end{array}$ & m. & $\begin{array}{r}11.42 \\
3.42\end{array}$ & $\begin{array}{l}22 \\
88\end{array}$ & & $\begin{array}{l}1.47 \\
3.47\end{array}$ & $\begin{array}{r}89 \\
94\end{array}$ & $\begin{array}{c}11.50 \\
3.47 \frac{1}{2}\end{array}$ & $\begin{array}{l}74 \\
30\end{array}$ & $\frac{11.501}{3.48}$ & & $\begin{array}{l}79 \\
78\end{array}$ & $\begin{array}{r}11.52 \\
3.50\end{array}$ & & \begin{tabular}{l|r}
66 & 11.521 \\
36 & 3.502
\end{tabular} & & 11. & $\begin{array}{l}53 \\
51\end{array}$ & $\begin{array}{l}66 \\
86\end{array}$ & $\begin{array}{r}11.55 \\
3.52\end{array}$ & $\begin{array}{l}82 \\
88\end{array}$ & $\begin{aligned} 11.55 \frac{1}{2} \\
3.52 \frac{1}{2}\end{aligned}$ & $\begin{array}{l}80 \\
71\end{array}$ & $\begin{array}{r}11.56 \\
3.53\end{array}$ \\
\hline \multirow{3}{*}{$\begin{array}{l}\text { Cu- } \\
\text { pola } \\
\text { test } \\
\text { No. }\end{array}$} & \multicolumn{24}{|c|}{ Record of melt-Continued. } \\
\hline & \multicolumn{24}{|c|}{ 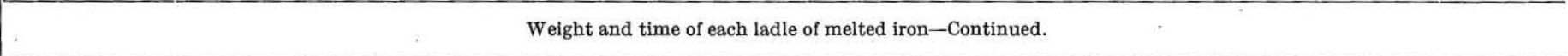 } \\
\hline & Lbs. & At- & Lbs & At & $t-$ & Lbs. & At- & Lbs. & At- & Lbs. & At & - & Lbs. & At- & Lbs. & At- & Lbs. & At- & Lbs. & At- & Lbs. & At-' & Lbs. & At- \\
\hline $\begin{array}{r}65 \\
188\end{array}$ & $\begin{array}{l}62 \\
84\end{array}$ & $\begin{aligned} 11.57 \\
3.54\end{aligned}$ & & \begin{tabular}{c|c}
95 & 11. \\
36 & 3.
\end{tabular} & $57 \frac{1}{2}$ & $\begin{array}{l}68 \\
79\end{array}$ & $\begin{array}{r}11.58 \\
3.55\end{array}$ & $\begin{array}{l}81 \\
86\end{array}$ & $\begin{array}{r}11.59 \\
3.56\end{array}$ & $\begin{array}{l}75 \\
89\end{array}$ & 11.5 & $59 \frac{1}{2}$ & $\begin{array}{l}68 \\
80\end{array}$ & $\begin{array}{r}12.00 \\
3.57\end{array}$ & $\begin{array}{l}74 \\
87\end{array}$ & $\begin{array}{r}12.01 \\
3.58\end{array}$ & $\begin{array}{r}146 \\
90\end{array}$ & $\begin{array}{l}12.01 \frac{1}{2} \\
3.58 \frac{1}{2}\end{array}$ & & 12. & $\begin{array}{l}85 \\
89\end{array}$ & $\begin{array}{r}12.04 \\
4.00\end{array}$ & $\begin{array}{r}136 \\
83\end{array}$ & $\begin{array}{r}12.04 \frac{1}{2} \\
4.00 \frac{2}{2}\end{array}$ \\
\hline \multirow{3}{*}{$\begin{array}{l}\text { Cu- } \\
\text { pola } \\
\text { test } \\
\text { No. }\end{array}$} & \multicolumn{14}{|c|}{ Record of melt-Continued. } & & & & & & & & & & \\
\hline & & & Weight & and tir & me of $e$ & each lad & dle of $\mathrm{m}$ & nelted iro & on-Cor & intinued. & & & & lting & & & & & Rem & marks. & & & & \\
\hline & Lbs. & At- & Lbs. & At- & Lbs. & At- & Lbs. & At- & Lbs. & At- & Lbs. & At- & & & & & & & & & & & & \\
\hline $\begin{array}{r}65 \\
188\end{array}$ & $\begin{array}{l}50 \\
66\end{array}$ & $\begin{array}{r}12.05 \\
4.01\end{array}$ & $\begin{array}{l}79 \\
87\end{array}$ & $\begin{array}{r}12.08 \\
4.02\end{array}$ & $\begin{array}{l}95 \\
87\end{array}$ & $\begin{aligned} & 12.08 \frac{1}{2} \\
& 4.02 \frac{1}{2}\end{aligned}$ & $\begin{array}{l}48 \\
88\end{array}$ & $\begin{array}{l}12.10 \frac{1}{2} \\
4.04\end{array}$ & $\begin{array}{l}26 \\
92\end{array}$ & $\begin{array}{l}12.11 \\
4.04 \frac{1}{2}\end{array}$ & $\dddot{89}$ & 4.06 & & $\begin{array}{l}29 \\
26\end{array}$ & $\begin{array}{l}\text { Iron hot. } \\
\text { Iron hot; }\end{array}$ & ; 27 th lac & dle -79 & pounds & at 4.07 & $07 ; 28$ th & ladle $-58 \mathrm{p}$ & pounds a & at 4.08 . & \\
\hline
\end{tabular}


Producer-gas test.-The following results were obtained from the producer-gas test made on the Ehrenfeld sample:

Producer-gas test on Lower Kittanning coal from Ehrenfeld.a

\begin{tabular}{|c|c|c|c|}
\hline & $\begin{array}{l}\text { Coal as } \\
\text { fired. }\end{array}$ & $\begin{array}{l}\text { Dry } \\
\text { coal. }\end{array}$ & $\begin{array}{l}\text { Com- } \\
\text { busti- } \\
\text { ble. }\end{array}$ \\
\hline \multicolumn{4}{|l|}{ Coal consumed in producer per horsepower per hour. } \\
\hline 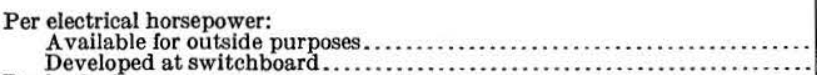 & $\begin{array}{r}\text { Pounds. } \\
1.25 \\
1.18\end{array}$ & $\begin{array}{r}\text { Pounds. } \\
1.22 \\
1.15\end{array}$ & $\begin{array}{r}\text { Pounds. } \\
1.13 \\
1.07\end{array}$ \\
\hline Per brake horsepower: & & & \\
\hline Available for outside purposes...................... & 1.06 & 1.04 & .96 \\
\hline 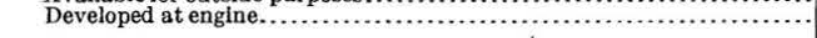 & 1.00 & .98 & \\
\hline \multicolumn{4}{|l|}{ Equivalent used by producer plant. } \\
\hline Per electrical horsepower: & & & \\
\hline 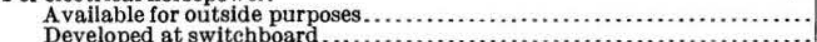 & $\begin{array}{l}1.35 \\
1.8\end{array}$ & 1.32 & 1.22 \\
\hline $\begin{array}{l}\text { Developed at switchboard } \ldots \ldots \ldots \ldots \ldots \ldots \ldots \ldots \ldots \ldots \ldots \ldots \ldots \ldots \ldots \ldots \ldots \\
\text { Per brake horsepower: }\end{array}$ & 1.28 & & 1.15 \\
\hline 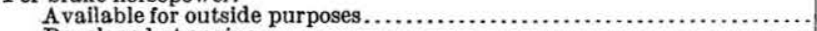 & 1.15 & 1.12 & 1.04 \\
\hline 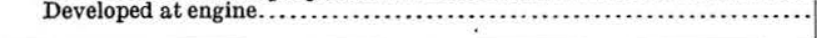 & 1.09 & 1.06 & \\
\hline
\end{tabular}

a Buil. U. S. Geol. Survey No. 290, 1906, pp. 180-181.

Size as shipped, run of mine; size as used, not determined. Duration, 50 hours. Average electrical horsepower, 187.9; average British thermal units gas per culic foot, 133; total coal fired, 11,100 pounds.

Analyses.

\begin{tabular}{|c|c|c|c|}
\hline Coal. & & Gas by volume. & \\
\hline 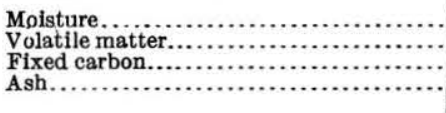 & $\begin{array}{r}2.49 \\
16.61 \\
73.70 \\
7.20\end{array}$ & 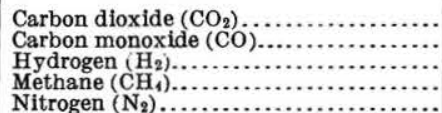 & $\begin{array}{r}9.9 \\
15.7 \\
14.1 \\
.2 .2 \\
5 \bar{y} .1\end{array}$ \\
\hline Sulphur... & $\begin{array}{r}100.00 \\
.91\end{array}$ & & 100.0 \\
\hline
\end{tabular}

Occurrence and physical character.-The Lower Kittanning coal near South Fork (see fig. 12) has a section similar to that of the bed near Johnstown, already described. Its main bench, however, is thicker, averaging nearly 4 feet and in some places reaching 5 feet, with no partings. The double structure-that is, the occurrence of a main bench with the under coal-which is fairly persistent in the Johnstown district, is even more apparent about South Fork. Some of the mines, however, show it only here and there. In other physical aspects this coal resembles the Lower Kittanning bed about Johnstown. Its roof of dense shale or sandstone, the general absence of "draw slate" or of clay veins, and the irregular floor are all common to the bed in both districts. The top few inches of the coal is usually bony and has to be discarded. In appearance the coal is lustrous and much of it is iridescent, and its columnar cleavage is one of its more characteristic features. 
The lower bench varies in thickness, but is in places as much as 2 feet thick; this thickness is reached near both South Fork and Mineral Point. The lower coal is underlain by valuable plastic clay and is separated from the main bench by a few inches to a foot of clay or shale. So far as known, the under coal is not utilized. As a rule it is not so persistent along the southeastern margin of the Wilmore Basin if the sections obtained by Mr. Butts and Mr. Phalen
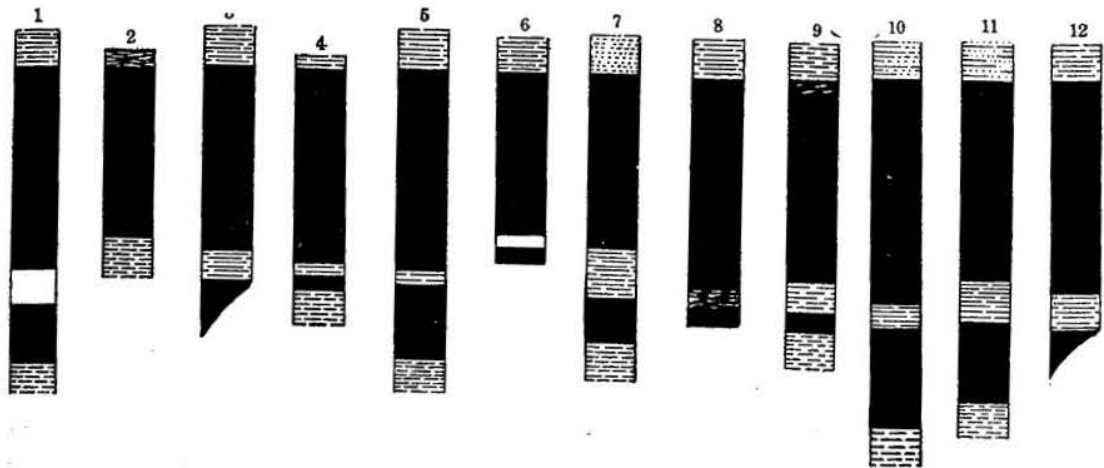

FIGURE 12.-Sections of Lower Kittanning (Miller or B) coal in the South Fork-Mineral Point district. Scale, 1 inch $=5$ feet.

1. Keystone Coal and Coke Company, Argyle No. 2, South Fork.

2. Keystone Coal and Coke Company, Argyle No. 1, South Fork.

3. Priscilla Coal Company, South Fork.

4. Pennsylvania, Beech Creek and Eastern Coal Company, Ehrenfeld.

5. Stineman Coal and Coke Company, No. 2, South Fork.

6. Stineman Coal and Coke Company, No. 4, South Fork.

7. Stineman Coal Mining Company, No. 1, South Fork.

8. Stineman Coal and Coke Company, No. 2, Timber opening, South Fork.

9. South Fork Coal Mining Company, No. 1, South Fork.

10. Valley Smokeless, No. 3, Mineral Point.

11. Page \& Reighard, Juniper mine, Mineral Point.

12. George Schafer, Mineral Point.

in 1903 are representative. It here appears locally, as the following section shows:

Section of Lower Kittanning (Miller) coal at Henriette shaft No. 1, Llanfair, Pa.

Coal.

Ft. in.

Slate. 3 9

Coal.

Clay.

LOWER ALLEGHENY COALS.

A coal 65 feet below the Lower Kittanning (Miller) bed has been opened at a few points about South Fork and Mineral Point. This coal probably corresponds to the Brookville or A coal. Most of the openings have fallen shut, but one bank is mined at South Fork to supply the local brick company. The coal is better known locally as the Dirty A or Six-foot coal, but where measured (see fig. 13) only $3 \frac{1}{2}$ feet of coal was observed. The bone parting observed a 
foot from the base is only an inch thick. The roof is shale or sandstone and so far as known gives no trouble. The coal runs as thick as 5 feet and as thin as 3 feet. According to reports, 4 feet may be considered an average. The coal is reported not to be rolly and no clay veins of importance have been encountered.

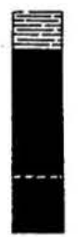

FiaURE 13.-Section of the Brookville (A) coal at the mine of J. H. Wickes, South Fork. Scale, 1 inch $=5$ feet.

It has a composition indicated by analysis 36 , page 41. From the high ash and sulphur content, aggregating more than 15 per cent, the coal deserves the name Dirty A, which is often applied to it. In other respects the analysis corresponds with those of other coals of the area, being relatively high in fixed carbon and low in volatile matter. It is possible that the coal may be valuable in this district, but the fact that it has not been developed on an extensive scale and apparently has not come into competition with the other coals of the district is strong presumptive evidence that in quality it is not up to the standard of the other coals mined about South Fork.

\section{POTTSVILLE COALS.}

But one other coal in the South Fork-Mineral Point district deserves brief attention. This is the coal associated with the flint clay (see pp. 121-123) at the Mercer horizon. The coal is not worked and where observed was merely a thin streak in the middle of the clay. The following section was seen and measured at the clay mine of J. H. Wickes:

Section of clay and coal at Mercer horizon, South Fork.

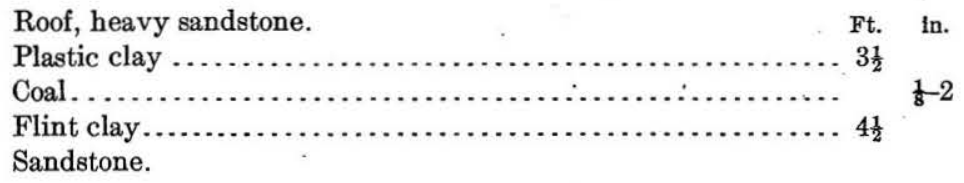

Though the coal is not workable here, it is quite possible that it may be of workable thickness locally. In this district, however, it can not be regarded as among the commercial beds of the future.

BLACKLICK CREEK DISTRICT.

EXTENT.

In the Blacklick Creek district will be included the coal occurrences along Blacklick Creek and its South Branch. Operations on these coals are confined almost exclusively to the creek valley, the principal mining towns being Nanty Glo, Cardiff, Twin Rocks, Weber, Vintondale, and Wehrum. The coals outcrop from Nanty Glo, where they are brought above drainage level on the east margin of the Laurel 
Ridge anticline, westward to Vintondale, on the west flank of the same anticline. Just west of Vintondale the highest workable coal disappears below drainage level, and still farther west, at Wehrum, mining operations are conducted by means of a shaft. West of Wehrum the coal-bearing beds are brought above drainage level just at the western edge of the quadrangle, near Dilltown. A few country banks have also been opened on Mardis Run.

GEOLOGIC POSITION OF COALS.

Figure 2 shows the relations between the principal coals in the Blacklick Creek district, and the following section, measured along the railroad and in the hills north of Vintondale, shows the character of the beds which make up the intervals:

\section{Section north of Vintondale.}

Sand and shale.

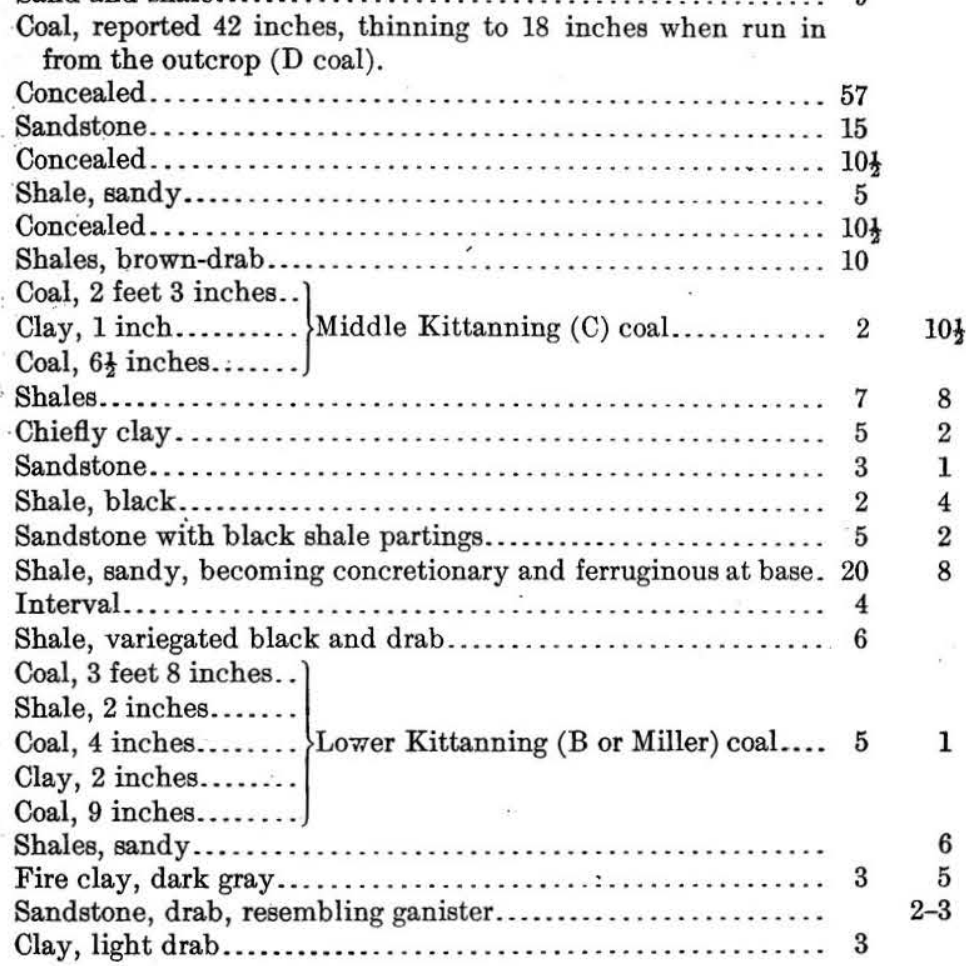

The Middle Kittanning (C) coal, the first above the Lower Kittanning (Miller or B) bed, which is the coal worked along Blacklick Creek, occurs at an interval above it of about 50 feet. This coal is nearer the Lower Kittanning at Nanty Glo, having been reported only 34 feet above it near the opening of the Ivory Hill Mining Company at that place. At Big Bend its interval above the Lower Kittanning is about 45 feet. 
There is still another coal at the top of the section deserving attention. At Vintondale a gully was dug up the hill from railroad level where the Lower Kittanning coal outcrops. The section given above, except the part between the Lower and Middle Kittanning coals, was measured in this gully. The top coal was observed by hand level to be 108 feet above the intermediate (Middle Kittanning or C) coal, and the interval between the Lower and Middle Kittanning beds was found to be $46 \frac{1}{2}$ feet. Thus from the top coal to the Lower Kittanning (B) bed the distance is about 164 feet. At Nanty Glo a workable coal (probably the Lower Freeport or D coal) was observed by hand-level measurement to occur 150 feet above the Lower Kittanning coal, and at Twin Rocks a coal was reported at almost exactly the same interval by the engineer of the Big Bend collieries. At Wehrum certain of the diamond-drill records show a coal about the same interval above the Lower Kittanning coal. So far as the writers are aware, this is the highest coal of any importance in the Blacklick Creek district. About 50 feet above it occurs an unworkable small coal, which is regarded as the equivalent of the Upper Freeport or $\mathrm{E}$ bed. The highest workable coal along Blacklick Creek will therefore be regarded tentatively as the Lower Freeport (D) coal.

The nomenclature of the coals discovered in the BlacklickCreek district and the intervals between them have been graphically given by D'Invilliers. ${ }^{a}$ He places the first coal above the Lower Kittanning (B) at 60 feet above it, but the hand-leveled sections at Vintondale, as well as measurements made at Twin Rocks and reports from authorities at Nanty Glo, make this coal at least 15 feet lower, and instead of lettering it $\mathrm{C}^{\prime}$, as $\mathrm{D}^{\prime}$ Invilliers has done, the writers prefer to regard it as the $\mathrm{C}$ coal and the representative of the Middle and not the Upper Kittanning bed. Further, D'Invilliers places the next higher coal at 120 feet above the Lower Kittanning (B) and the next at approximately 60 feet higher. This bed, which he denotes as the $\mathrm{E}$ with a question, he describes as a "good bed, thinning westward to about 3 feet." It is believed that this is the coal measured at Nanty Glo, at Twin Rocks, near Rexis, and on Mardis Run, though the interval obtained (150 to 160 feet above the Lower Kittanning bed) falls short by at least 20 feet of the interval platted by D'Invilliers.

\section{ALLEGHENY COALS.}

LOWER FREEPORT (D) COAL.

Name and position.-Some question arises as to whether the highest workable coal in the Allegheny formation is the Upper or Lower Freeport. It is quite certain that the full complement of coals in the formation is not developed along Blacklick Creek, at 
least not as clearly as in the Johnstown Basin. Only three workable coals in the Allegheny (above and including the B bed) were determined with any certainty, and, though more may be present, they must be small and hence of no value except for stratigraphic purposes.

The position of the highest workable coal is very definitely fixed. At Nanty Glo it is just 150 feet by hand level above the Lower Kittanning (B) bed. On the Selderville road, between Nanty Glo and Twin Rocks, the interval, measured by barometer, is 158 feet; at Vintondale, by hand level, it was made 164 feet; and, as stated by the engineer of the Big Bend collieries, the interval at Big Bend is about 150 feet. There is a question as to whether this coal is the Upper Freeport or the Lower Freeport, and this question the writers are unable to settle definitely. Objection should not be made to its being considered as the Upper Freeport on the basis of its small interval above the Lower Kittanning coal, as this interval is even less than 150 feet at New Germany. In this report, however, it will be regarded as the Lower Freeport coal.

Extent and development.-The Lower Freeport (D) coal has been opened by the Ivory Hill Coal Mining Company east of Nanty Glo and on the side of the hill just west of the No. 14 colliery of the Pennsylvania, Beech Creek, and Eastern Coal Company. It has been prospected and its position and character are well known at Twin Rocks and to the northeast, opposite No. 2 colliery of the Big Bend Coal Mining Company. About Vintondale it has been prospected and its character is known, as a section of the coal near Rexis was measured by Mr. Martin. On Mardis Run, just off the northwest corner of the Johnstown quadrangle, the coal is opened and a section was measured. At present it is not a commercial factor in the Blacklick Creek district, but it can be classed among the future commercial coals of this district.

Occurrence and physical character.-Figure 14 shows the mode of occurrence of the Lower Freeport coal. It generally consists of two
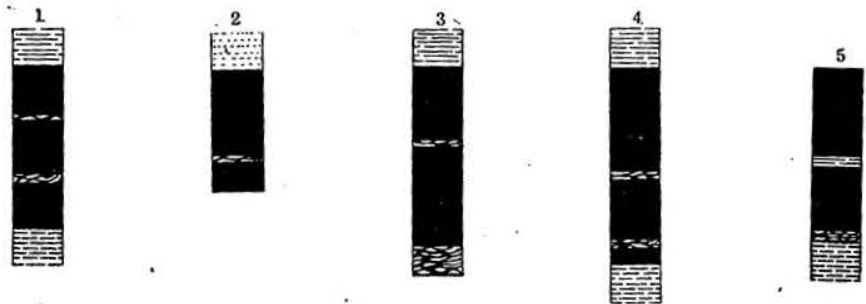

Figure 14.-Sections of the Lower Freeport (D) coal along Blacklick Creek. Scale, 1 inch $=5$ feet.

1, Mardis Run near northwest edge of Johnstown quadrangle; 2, Blacklick Creek near Rexis; 3, road south of Twin Rocks; 4, Twin Rocks; 5, Ivory Hill Coal Mining Company, Nanty Glo.

or three benches separated by thin bone partings, the coal aggregating from 3 to $3 \frac{1}{2}$ feet in thickness. At Vintondale, Twin Rocks, $69516^{\circ}-$ Bull. $447-11-6$ 
and Nanty Glo the upper bench varies from $1 \frac{1}{2}$ to nearly 2 feet in thickness, and the lower bench averages about 15 inches, with scme few inches of bone beneath. At Twin Rocks this is underlain by a few inches of coal. On Mardis Run the coal is more broken, consisting of three benches, each about a foot thick. The roof is usually shille and the coal is underlain by clay. The presence of the parting in this coal has been a drawback to operations on it, but it is quite probable that it will yet be worked; in fact, it was worked during the harclcoal famine of 1902-3 and gave satisfaction. If proper care is excrcised in separating the bony parting, it should be readily marketed. The resemblance of the sections to those of the Upper Freeport coal near South Fork is marked.

MIDDLE KITTANNING COAL. .

A little more than 100 feet below the Upper Freeport coal and from 35 to 45 feet above the main coal of the Blacklick district (Lower Kittanning or Miller bed) occurs a coal which is persistent along South Branch of Blacklick Creek. It has been observed at Twin Rocks, Nanty Glo, and Vintondale, and its interval with respect to the main Blacklick coal has been measured at the two last-named places. It has been called the Middle Kittanning coal because it is the first coal above the Lower Kittanning bed. At Vintondale the following section was measured:

Section of Middle Kittanning coal at Vintondale.

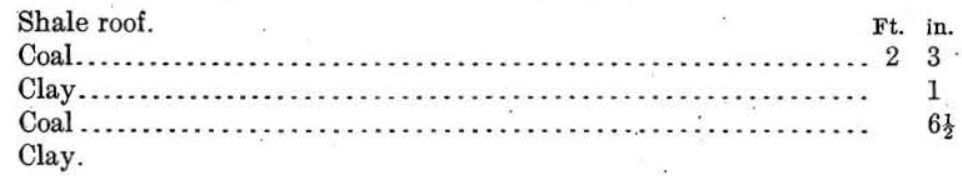

The coal here has a thickness of $33 \frac{1}{2}$ inches and is therefore workable. Owing to its persistence, it may be regarded as among the coals that will in the future be worked in this region, though it may be some time before it will be necessary to draw on this coal as a source of supply.

$$
\text { LOWER KITTANNING (B) COAL. }
$$

Name and position.-The main coal of the Blacklick district is considered the Lower Kittanning (Miller or B) coal and corresponds to this coal about South Fork. Some question has been raised as to this correlation and the coal has been regarded as the equivalent of the Upper Kittanning or $\mathrm{C}^{\prime}$ coal. The objections to the latter view have been summed up by D'Invilliers ${ }^{a}$ in the following words, with which the writers are in full agreement.

The whole character of the "Blacklick seam" is totally unlike the appearance of the Kittanning upper bed $\left(\mathrm{C}^{\prime}\right)$ as exposed anywhere in Clearfield, Cambria, or Somersel counties. On the other hand, its double structure, columnar cleavage, partings, roof 
and floor, and excellent chemical character most strongly resemble the features of the Kittanning lower bed (B or Miller seam), all through southern Cambria and especially in the Paint and Shade Creek valleys of Somerset County. *** At no place in the Blacklick region has the cement bed been noticed beneath this coal, which would identify it as bed $\mathrm{C}^{\prime}$.

Extent and development.-This coal is often referred to as the Blacklick Creek seam. It appears above drainage level just east of Nanty Glo, on South Branch of Blacklick Creek, where it has been opened by the Ivory Hill Coal Mining Company. In the southern part of Nanty Glo are two important mines on this coal-the Pennsylvania, Beech Creek, and Eastern Coal Company's colliery No. 14 and that of the Nanty Glo Coal Mining Company. Some distance north of the town is the mine of the Lincoln Coal Company, and still farther north, near the edge of the quadrangle, is the opening of the Cardiff Coal Company. The next mining center to the west is Twin Rocks or Expedit postoffice, near which are located collieries Nos. 1 and 2 of the Big Bend Coal Mining Company and colliery No. 3 of the Commercial Coal Mining Company. Colliery No. 4 of the latter company is located about 4 miles farther west, at a little settlement called Weber. The Vinton Colliery Company controls the workings on this bed about Vintondale. Four out of its five collieries were active in the summer of 1906 and colliery No. 6 was just being opened. The coal goes below drainage level in the town and the operations to the west at Wehrum are conducted by shafting for the coal to a depth of 187 feet. On the west side of the Barnesboro or Westover Basin the bed appears above drainage level just at the edge of the quadrangle and has been worked in a small way by H. R. Dill about a mile northwest of Dilltown. The development of this coal along Blacklick Creek is of recent date, and the production of this district, which was only 5,000 tons in 1894, had incrèased in 1905 to $1,045,802$ tons, valued at $\$ 1,019,617$.

Chemical character. - The composition of this coal is indicated by analyses 17 to 27 (pp. 40-41). This exceptionally complete series of analyses shows that the Lower Kittanning (Miller) coal has much the same character along Blacklick Creek as at Johnstown and South Fork. The moisture in the coal is low, in no sample exceeding 4 per cent. The volatile matter is likewise low and remarkably uniform, ranging from more than 17 per cent.to less than 19 per cent. Fixed carbon ranges from 67 to 73 per cent-a slight range considering that the samples were obtained by three individuals from scattered mines. Ash is on the whole low, but sulphur is rather high, in one sample exceeding $4 \frac{1}{2}$ per cent. As a whole, however, the figures all point to a high-grade coal.

Steaming tests.-Steaming tests have been made on Lower Kittanning coal collected at Wehrum by the United States Geological Survey. ${ }^{a}$ The analyses on the samples used are as follows: 
Chemical analyses of Lower Kittanning coals from Wehrum.a

\begin{tabular}{|c|c|c|c|c|}
\hline & & Test 472 . & Test 473. & Test 467 . \\
\hline 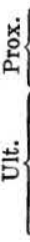 & 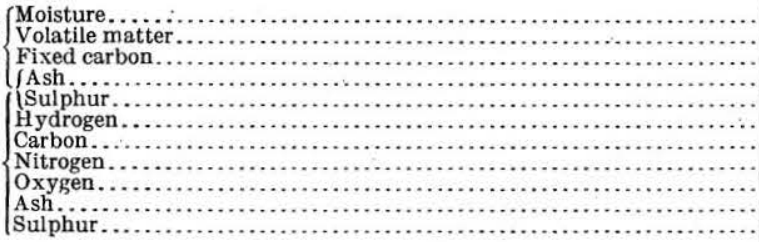 & $\begin{array}{r}1.88 \\
17.60 \\
69.06 \\
11.46 \\
5.37 \\
4.13 \\
75.63 \\
1.15 \\
1.94 \\
11.68 \\
5.47\end{array}$ & $\begin{array}{r}2.45 \\
17.55 \\
70.56 \\
9.44 \\
3.87 \\
4.31 \\
78.83 \\
1.21 \\
2.00 \\
9.68 \\
3.97\end{array}$ & $\begin{array}{r}3.90 \\
23.35 \\
\text { W. } .65 \\
5.10 \\
3.11 \\
1.35 \\
: .71 \\
1.09 \\
1.18 \\
5.43 \\
3.24\end{array}$ \\
\hline
\end{tabular}

a Proximate analysis of fuel as fired; ultimate analysis of dry fuel figured from car sample. (See analyses 10 and 11, pp. 40-41.)

The results of the steaming tests are as follows:

Steaming tests on Lower Kittanning coal from Wehrum.

\begin{tabular}{|c|c|c|c|}
\hline . & Test 472.a & Test 473. $a$ & Test ;67. \\
\hline Size as used: & & & \\
\hline $\begin{array}{l}\text { Over } 1 \text { inch }, \\
\text { inch to } 1 \text { inch }\end{array}$ & 8.2 & $\begin{array}{l}4.6 \\
6.9\end{array}$ & \\
\hline 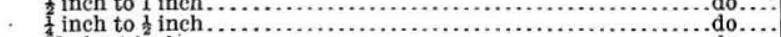 & $\begin{array}{l}11.1 \\
19.2\end{array}$ & $\begin{array}{r}6.9 \\
13.9\end{array}$ & \\
\hline 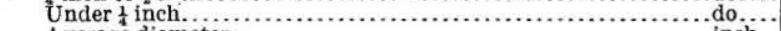 & 61.5 & 74.6 & \\
\hline A verage diameter ............ & 0.41 & 0.31 & \\
\hline Duration of test....... & 8.75 & 9.77 & \\
\hline $\begin{array}{l}\text { Heating value of fuel.............. } \\
\text { Force of draft: }\end{array}$ & 13,729 & 14,240 & 14. 258 \\
\hline Under stack damper..... & 0.81 & 0.82 & \\
\hline $\begin{array}{l}\text { Above fire................. } \\
\text { Furnace temperature.... }\end{array}$ & 2.512 &. .23 & \\
\hline Dry fuel used per square foot of grate surface per hour.............po & 16.87 & 17.24 & 1. 1.63 \\
\hline $\begin{array}{c}\text { Equivalent water evaporated per square foot of water-heating surface per } \\
\text { hour }\end{array}$ & & & \\
\hline 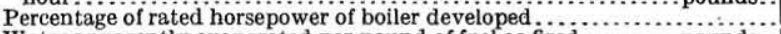 & 84.2 & 91.2 & \\
\hline $\begin{array}{l}\text { Water apparently evaporated per pound of fuel as fired........... pounds.. } \\
\text { Water evaporated from and at } 212^{\mathrm{b}} \mathrm{F} \text { : }\end{array}$ & 7.27 & 7.65 & \\
\hline Per pound of fuel as fired............ & 8. 76 & 9.22 & \\
\hline 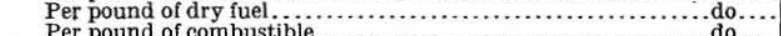 & & 9.45 & 0.04 \\
\hline $\begin{array}{l}\text { Per pound of combustible................ } \\
\text { Efficiency of boiler, including grate........ }\end{array}$ & $\begin{array}{l}10.57 \\
62.81\end{array}$ & $\begin{array}{l}10.85 \\
64.09\end{array}$ & $\begin{array}{l}11.30 \\
6 \times .10 \\
0\end{array}$ \\
\hline Fuel as fired: & & & \\
\hline 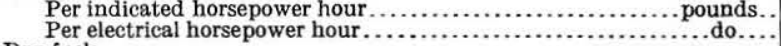 & $\begin{array}{l}3.23 \\
3.99\end{array}$ & $\begin{array}{l}3.07 \\
3.79\end{array}$ & $\begin{array}{l}\text { 2. } 93 \\
\text { 3. } 1 \text { i2 }\end{array}$ \\
\hline $\begin{array}{l}\text { Dry fuel: } \\
\text { Per indicated horsepower hour } \ldots \ldots \ldots \ldots \ldots \ldots \ldots \ldots \ldots \ldots \ldots \ldots \ldots \ldots \ldots \\
\text { do } \ldots \ldots \ldots \ldots\end{array}$ & & & \\
\hline Per electrical horsepower hour........................ & 3.91 & 3.69 & \\
\hline
\end{tabular}

Test 467 made on Renfrow briquets from briquetting test 176 ( ). 87 ), which burned freely with short flame, 5.4 per cent black smoke, and very hot fire; briquets coking well and throwing off fragments of coke in ash during combustion; 39 per cent clinker, thin, metallic, red and black, brittle when cold; ash of dark-gray color, looked like coke.

The figures giving the pounds of water evaporated from and at it temperatura of $212^{\circ} \mathrm{F}$. per pound of dry fuel used represent the value of the coal for steaming. The first two tests give 8.93 ani 9.45 , or an average of 9.19 , which compares very well with 10.545 the figure for the first-class steaming coal from Fayette, W. Va. (See 
p. 37.) The figure for test 467 (10.04) represents the steaming value of briquets and strictly speaking should not be used in making comparisons with the results obtained from the raw coal.

Coking tests.-The results of the coking tests made on this coal are given below. ${ }^{a}$

Coking tests on Lower Kittanning coal from Wehrum.

[Run of mine, washed.]

\begin{tabular}{|c|c|c|}
\hline & Test 185. & Test 188. \\
\hline 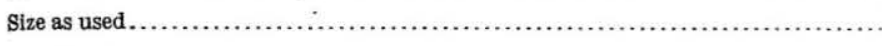 & Finely & Run of \\
\hline 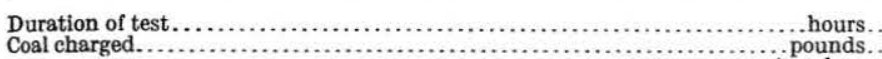 & $\begin{array}{r}\text { crushed. } \\
61 \\
9,750\end{array}$ & $\begin{array}{r}\text { mine. } \\
\\
\end{array}$ \\
\hline 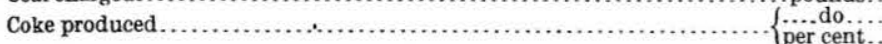 & 5,779 & 8,144 \\
\hline Breeze produced... & 262 & 332 \\
\hline Total yield........... & $\begin{array}{r}2.69 \\
61.96\end{array}$ & $\begin{array}{r}2.66 \\
68.02\end{array}$ \\
\hline
\end{tabular}

Analyses of coal and coke.

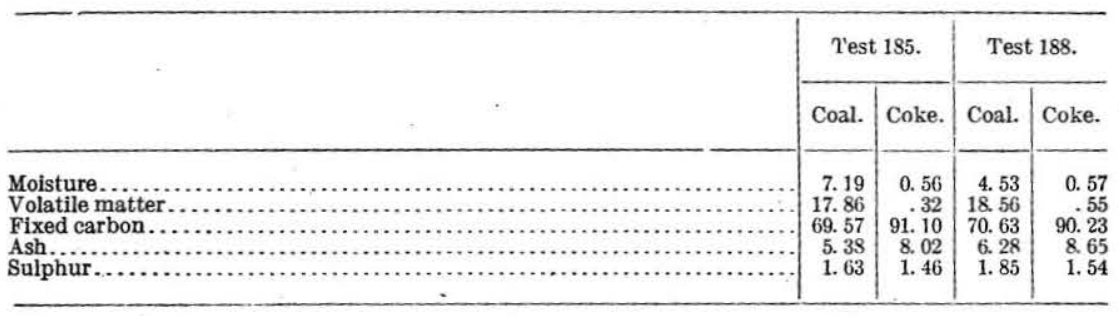

The coke resulting from the first test was of a dull-gray color, soft and dense, with high sulphur. The second test, with run-ofmine coal, produced a light-gray silvery coke, much better than the coke from the finely ground coal. In the coke from the second test, also, the sulphur is high. The yield in the second test was much better than that in the first. The coal mined at Nanty Glo from this bed has been tested in beehive ovens at Gallitzin. It produced coke of good structure but of dull appearance. As in the Wehrum samples, an insufficient amount of sulphur was volatilized. The Lackawanna Coal and Coke Company has experimented with its coal about Wehrum, but the washeries have long been closed and the results of the coking tests could not be learned. The Vinton Colliery Company has recently built a large by-product plant at Vintondale and a large part of the coal mined from colliery No. 6 in 1907 was coked in it. 
86 MINERAL RESOURCES OF JOHNSTOWN, PA., AND VICINITY.

Producer-gas test.-The following producer-gas test was made:

Producer-gas test on Lower Kittanning coal from Wehrum.a

\begin{tabular}{|c|c|c|c|}
\hline . & $\begin{array}{l}\text { Coal as } \\
\text { fired. }\end{array}$ & Dry coal. & $\begin{array}{l}\text { Combus- } \\
\text { tible. }\end{array}$ \\
\hline Coal consumed in producer per horsepower per hour. & & & \\
\hline $\begin{array}{l}\text { Per electrical horsepower: } \\
\quad \text { Commercially available } \\
\text { Developed at switchboard } \ldots \ldots \ldots \ldots \ldots \ldots \ldots \ldots \ldots \ldots \ldots \ldots \ldots \ldots \ldots \ldots\end{array}$ & $\begin{array}{r}\text { Pounds. } \\
1.29 \\
1.24\end{array}$ & $\begin{array}{r}\text { Pounds. } \\
1.26 \\
1.21\end{array}$ & $\begin{array}{r}\text { Pounds. } \\
1.12 \\
1.08\end{array}$ \\
\hline 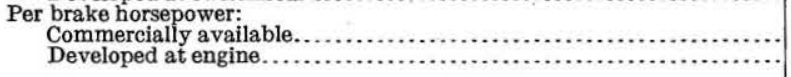 & $\begin{array}{l}1.10 \\
1.05\end{array}$ & $\begin{array}{l}1.07 \\
1.03\end{array}$ & $\begin{array}{r}.96 \\
.92\end{array}$ \\
\hline Equivalent used by producer plant. & . & & . \\
\hline 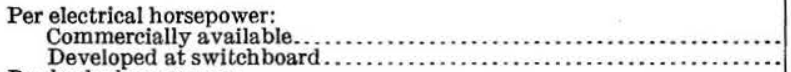 & $\begin{array}{l}\text { 1. } 43 \\
1.37\end{array}$ & $\begin{array}{l}1.39 \\
1.34\end{array}$ & $\begin{array}{l}1.25 \\
1.20\end{array}$ \\
\hline Per brake horsepower: & & & \\
\hline $\begin{array}{l}\text { Commercially available....... } \\
\text { Developed at engine........ }\end{array}$ & 1. 17 & $\begin{array}{l}1.18 \\
1.14\end{array}$ & $\begin{array}{l}1.06 \\
1.02\end{array}$ \\
\hline
\end{tabular}

a Lump cool.-Size as used: Over 1 inch, 7 per cent; $\frac{1}{2}$ inch to 1 inch, 14 per cent; $\frac{1}{4}$ inch to $\frac{1}{2}$ inch, 18 per cent; under ${ }_{4}^{1}$ inch, 61 per cent. Duration of test, 24 hours. Average electrical horsepower, 191.8. Average B. t. u. per cubic foot of gas, 144.4. 'Total coal fired, 5,700 pounds.

\section{Analysis of gas by volume.}

Carbon dioxide $\left(\mathrm{CO}_{2}\right)$ 10. 7

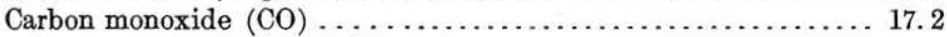

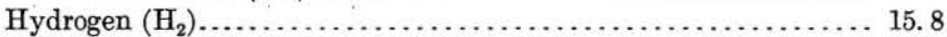

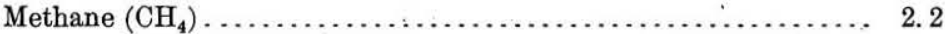

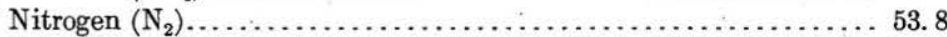

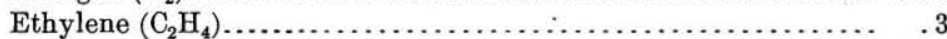

Washing tests.-Washing tests were made as follows. The figures indicate that finer crushing is advantageous. The loss of "good coal " (by which is meant all coal of a quality equal to or better than that of the washed coal) in the refuse will not exceed 2 per cent.

Float and sink tests of Lower Kittanning coal from Wehrum.

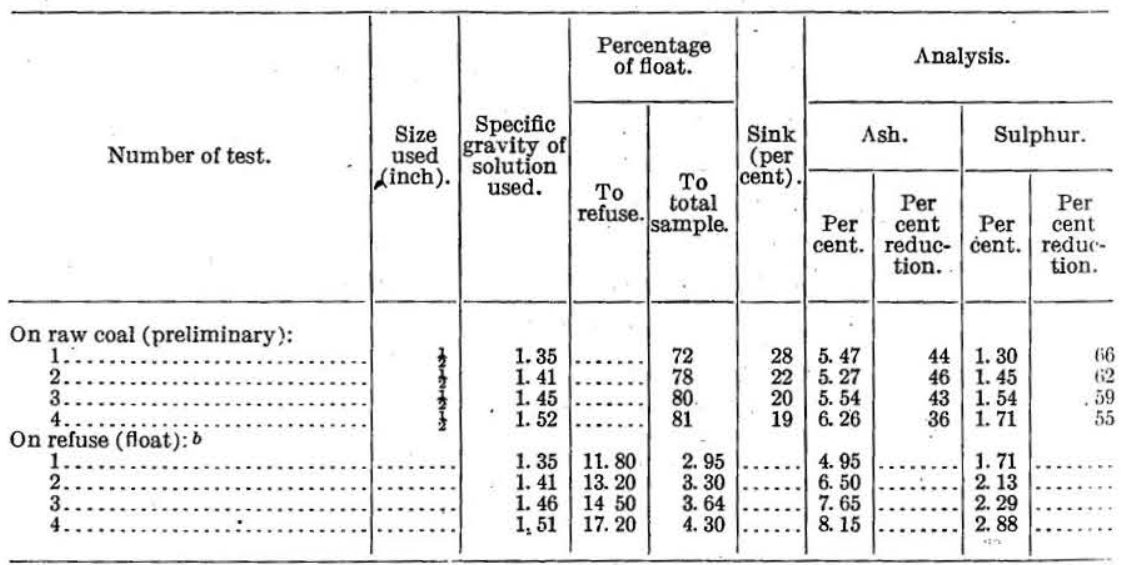

a For analyses of fuel used see analysis 27, p. 41 .

$b$ Duration of test, 2 hours. Size as used, through 1-inch screen. Jig used, special; speed, 70 revolutions per minute; stroke, $2 \frac{1}{2}$ inches. Raw coal, 20.37 tons; washed coal, 15.25 tons, or 75 per cent; refuse, 5.12 tons, or 25 per cent. 
Analyses.

\begin{tabular}{|c|c|c|c|c|c|c|}
\hline & \multirow{2}{*}{ Sample tested. } & \multirow[b]{2}{*}{$\begin{array}{l}\text { Moist. } \\
\text { ure. }\end{array}$} & \multicolumn{2}{|c|}{ Ash. } & \multicolumn{2}{|c|}{ Sulphur. } \\
\hline & & & $\begin{array}{c}\text { Per } \\
\text { cent. }\end{array}$ & $\begin{array}{l}\text { Per } \\
\text { cent } \\
\text { reduc- } \\
\text { tion. }\end{array}$ & $\begin{array}{l}\text { Per } \\
\text { cent. }\end{array}$ & $\begin{array}{l}\text { Per } \\
\text { cent } \\
\text { reduc- } \\
\text { tion. }\end{array}$ \\
\hline $\begin{array}{l}\text { Rave } \\
\text { Washe } \\
\text { Refuse }\end{array}$ & . & $\begin{array}{l}\text { 3. } 13 \\
\text { 6. } 45 \\
5.78\end{array}$ & $\begin{array}{r}9.81 \\
5.38 \\
47.18\end{array}$ & 45 & $\begin{array}{r}3.77 \\
1.53 \\
19.78\end{array}$ & $\dddot{59}$ \\
\hline
\end{tabular}

Briquetting tests.-Two briquetting tests were made of the coal. Test 176, with 7 per cent binder (water-gas pitch), gave satisfactory briquets, which were tough and easily handled without breaking when warm, but which were brittle when cold; they broke with characteristic smooth, glossy fracture, hard surface, and sharp edges. In test 184 the Wehrum coal was mixed with an approximately equal portion of anthracite graphitic coal from Cranston, near Providence, R. I. From this mixture excellent briquets were made with 6.25 per cent binder on the Renfrow (American) machine. Although the pitch used had a low melting point, the briquets handled well from the machine and piled without stocking. The outer surface was very hard and smooth and broke without crumbling, giving a smooth fracture and sharp edges.

Briquetting tests of coal from Wehrum.

\begin{tabular}{|c|c|c|c|c|c|}
\hline & $\begin{array}{l}\text { Test } \\
176 . a\end{array}$ & $\begin{array}{l}\text { Test } \\
184 . b\end{array}$ & & $\begin{array}{l}\text { Test } \\
176 .\end{array}$ & $\begin{array}{l}\text { Test } \\
184 .\end{array}$ \\
\hline 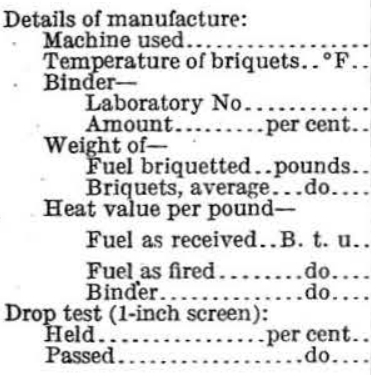 & $\begin{array}{r}\text { Renf. } \\
185 \\
4553 \\
7 \\
8,000 \\
0.420 \\
\\
13,712 \\
13,702 \\
16,969 \\
50.5 \\
49.5\end{array}$ & $\left\{\begin{array}{r}\text { Renf. } \\
185 \\
4543 \\
6.25 \\
10,000 \\
0.5 \\
c 13,712 \\
d 10,996 \\
12,793 \\
16,9 \in 6 \\
68.5 \\
31.5\end{array}\right.$ & 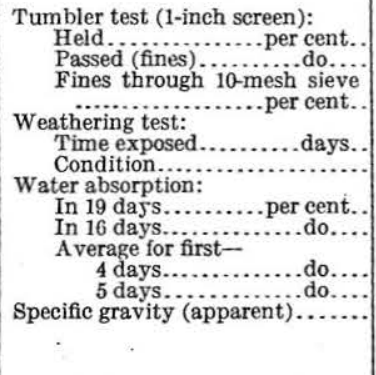 & $\begin{array}{r}70.5 \\
29.5 \\
85.0 \\
53 \\
e \AA \\
22.0 \\
\cdots \ldots . . \\
4.05 \\
\hdashline 1.043\end{array}$ & $\begin{array}{r}93.0 \\
7.0 \\
91.4\end{array}$ \\
\hline
\end{tabular}

$a$ Size as used: Over $\frac{1}{4}$ inch, 2.2 per cent; $\frac{1}{10}$ inch to $\frac{1}{3}$ inch, 6 per cent; $\frac{1}{20}$ inch to $\frac{1}{10}$ inch, 12 per cent; id inch to $\frac{1}{2}$ inch, 19 per cent; through $\frac{1}{10}$ inch, 60.8 per cent.

$b$ Size as used: Over $\frac{1}{6}$ inch, 0.8 per cent; $\frac{1}{10}$ inch to $\frac{1}{4}$ inch, 7 per cent; $\frac{2}{2} \frac{1}{2}$ inch to $\frac{1}{16}$ inch, 15 per cent; of inch to $\frac{1}{20}$ inch, 22.2 per cent; through to inch, 55 per cent.

¿ Coal from Wehrum, Pa.

come contion or

pitting. Briquets hard with sharp edges and fracture same as that of new briquets. See Bull. U.S. Geol. Survey No. 332, 1908, p. 43. 
Extraction analyses.

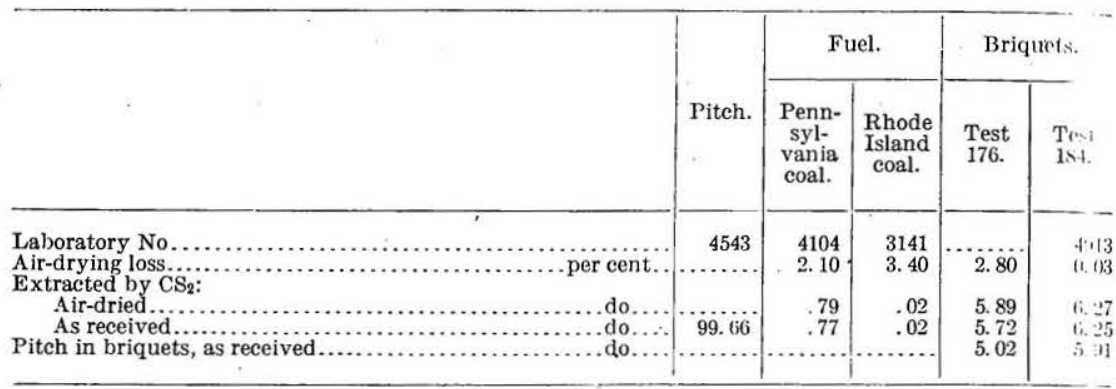

Occurrence and physical character.-In its mode of occurrence the Lower Kittanning bed on Blacklick Creek strongly resembles in its main features the same coal in the districts along Conemaugh River. (See fig. 15.) The coal is made up of a bench from $3 \frac{1}{2}$ to 4 feet thick and of either one or two lower benches. In a few places both lower benches are missing (see sections 2, 5, and 6); the absence of both lower benches is, however, only local, for in the same mine the upper of the two has been observed at one place but has disappeared a short distance away. The lowest bench was not observed about South Fork or Johnstown but is persistent along Blacklick Creek. Here and there the main bench is underlain by bone. The middle bench is thin, averaging not more than 4 or 5 inches. The lower bench is 2 feet thick in places. The two shale partings inclosing the middle bench are thin, rarely exceeding a few inches in thickness. The analyses (see pp. 41-42) represent coal from the main bench; that from the middle thin bench is reported good but too thin to mine; anil that from the lowest bench is high in ash and sulphur and usuallytoo impure to ship. Below the lowest bench occurs a good deposit of clay, which has never been exploited along Blacklick Creek. The roof of the coal is either very firm shale or sandstone. The character of the roof, the irregularity of the floor, the general absence of clay veins, and the nongaseous nature of the coal are points in which it is similar to the Lower Kittanning (Miller) bed in the Conemaugh Valley. The coal is bright and lustrous, with a marked tendency to: columnar cleavage. 

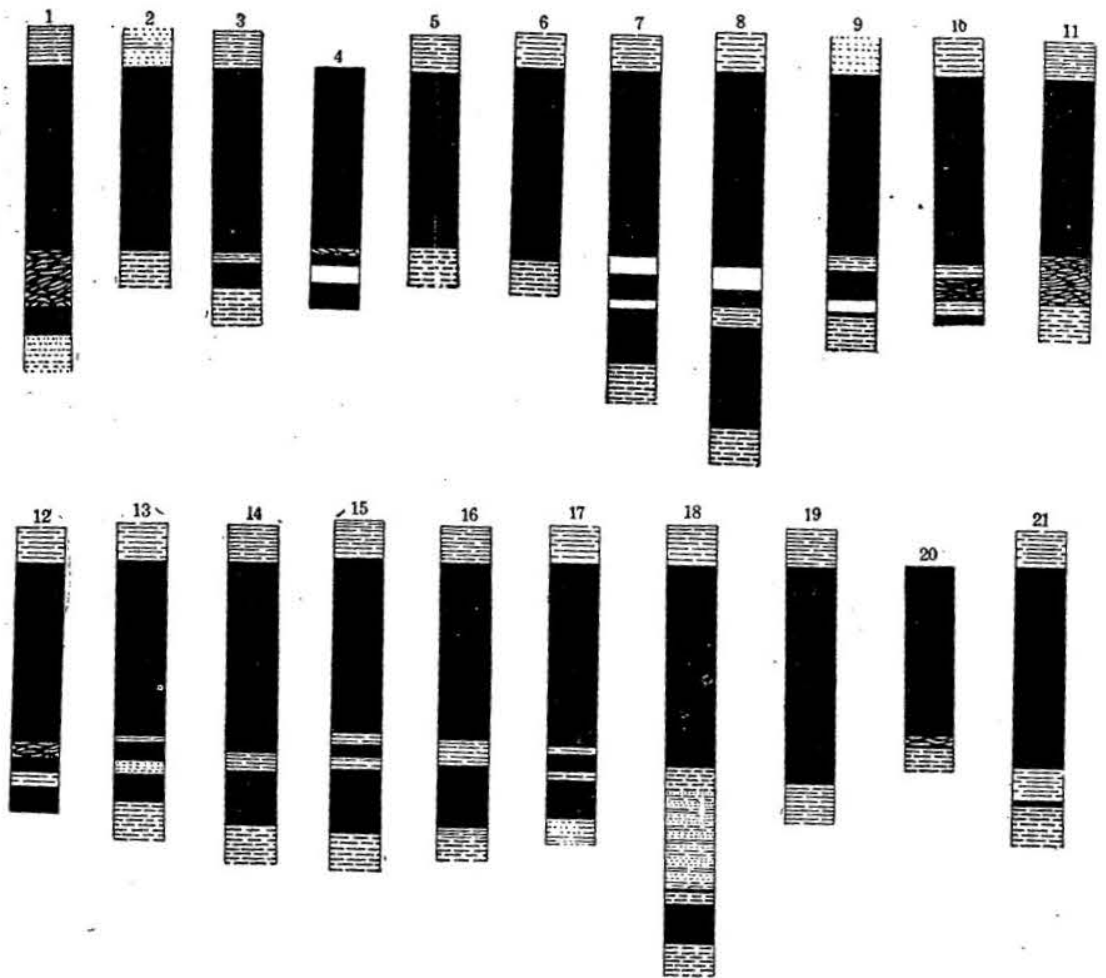

FIGURE 15.-Sections of the Lower Kittanning (Milier or B) coal in the Blacklick Creek district. Scale, 1 inch $=5$ feet.

1. Pennsylvania, Beech Creek and Eastern Coal Company No. 14, Nanty Glo.

2. Nanty Glo Coal Mining Company No. 1, Nanty Glo.

3. Lincoln Coal Company, Nanty Glo.

4. Ivory Hill Coal Mining Company, Nanty Glo.

5. Cardiff Coal Company, 5 miles north of Nanty Gilo.

6. Country bank $1 \frac{1}{2}$ miles north of Nanty Glo.

7, 8. Commercial Coal Mining Company No. $3,1 \frac{1}{2}$ miles east of Twin Rocks.

9. Big Bend Coal Mining Company, Nonpareil No. 1, Twin Rocks.

10. Big Bend Coal Mining Company, Big Bend Colliery No. 2, Twin Rocks.

11. Vinton Colliery Company No. 1, Vintondale.

12. Vinton Colliery Company No. 2, Vintondale.

13. Vinton Colliery Company No. 6, Vintondale.

14, 15. Vinton Colliery Company No. 3, Vintondale.

16. Vinton Colliery Company No. 5 , Vintondale.

17. Exposure in railroad cut east of Vintondale.

18, 19. Lackawanna Coal and Coke Company No. 4, Wehrum.

20. Amos Rager, Rummel Run.

21. H. R. Dill, $1 \frac{1}{2}$ miles northwest of Dilltown.

\section{LOWER ALLEGHENY COALS.}

Along Blacklick Creek other coals are known which are below the Lower Kittanning bed. In the railroad cut near Twin Rocks these lower coals show, as they do also a short distance east of Weber. Just where the spur track turns in to the collieries of the Big Bend Co.l Company at Twin Rocks the following section was measured: 
Section of Brookville and Clarion coals (?) near Big Bend.

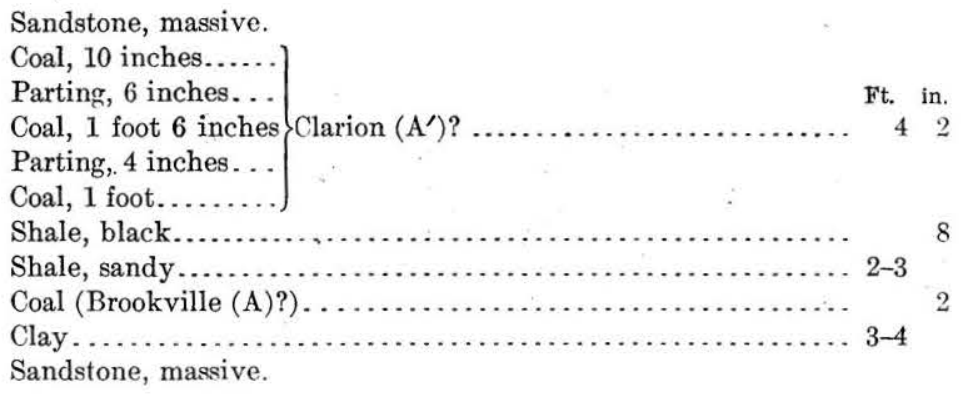

From the massive sandstones about the place where the section was made it is impossible to be absolutely sure that this coal is in the Allegheny. The massive sandstone overlying the coal in the cut may be traced northward along the nose where the river makes the big bend for some distance-in fact, so far as to make it fairly certain that it is an Allegheny sandstone and to corrobor ats the view that the coal whose section is given above probably corresponds to the lowest coal or coals in the Allegheny formation. One of these lower coals has been opened about 43 feet above the railroad tracks just back of Twin Rocks railroad station, but the bank is now fallen shut. The coal was reported as present only in patches and was known in the locality as the Three-foot seam or Sulphur vein.

The view that the coal in the cut near Twin Rocks is in the Allegheny formation and at its base is strengthened by observations made on the highway and along the railroad farther west, near Weber. Near Commercial No. 4 mine the massive sandstones may be observed close below the Lower Kittanning (B) coal, and at an estimated interval of 71 to 77 feet below are found two coals thought to correspond with the coals given in the foregoing section. These are regarded, on stratigraphic grounds, as Allegheny coals, and the massive sandstone is believed to be the Kittanning sandstone member. This heavy sandstone coming at the base of the Allegheny makes it difficult to conclude as to the position of the base of this formation, especially where the evidence has to be obtained at scattered points in different sections. This massive sandstone, however, is known to occur at other places in or near the quadrangle where the relations are plain and where there is no doubt as to its being in the Alleghenyfor instance, south of the quadrangle, along Stony Creek.

Near Weber, as near Twin Rocks, the two coals occurring at the base of the Allegheny are too thin to be worked, each being less than a foot thick. The sections containing these two coals, regarded as the Brookville (A) and the Clarion $\left(\mathrm{A}^{\prime}\right)$ coals, are given below. The first section was measured by Mr. Martin and the second and third by Mr. Phalen. 
Sections of Brookville and Clarion coals near Weber.

1. Section on both sides of railroad cut.

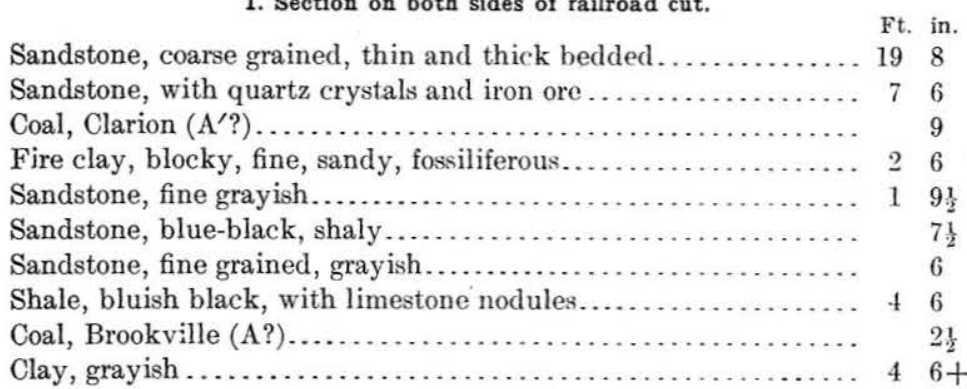

2. Section on north side of cut.

Sandstone.

Coal (bony in middle), Clarion $\left(A^{\prime}\right)$

Ft, in.

Fire clay, gravelly, sandy, almost sandstone. Contains abundant organic impressions (fossil imprints), but they are very poor. 5

Shale, drab or dark gray .......................... 4

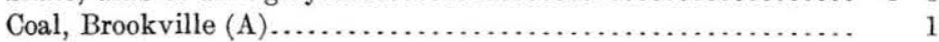

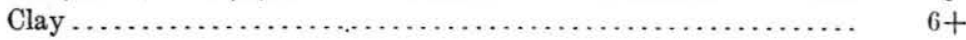

3. Section on south side of cut.

Sandstone. Ft. in.

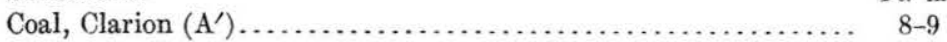

Sandstone, gnarly, or sandy fire clay with plant impressions..... $6 \quad 6 \quad 6$

Shale, dark, with concretions....................... 49

Coal, Brookville (A)................................ 2

Shales, dark, irregularly bedded, upper part resembling fire clay. 4

The dip from the south to the north side of the track is marked, even for so short a distance.

\section{WINDBER DISTRICT.}

EXTENT.

The Windber district of this report includes the territory about the town of Windber, situated within the Johnstown quadrangle.

\section{GEOLOGIC POSITION OF THE COALS.}

All the workable coals in this district are found in the Allegheny formation, which is above drainage level in all the hills surrounding Windber and Scalp Level. Of these coals, only the Lower Kittanning is now worked, but higher coals are known to be valuable.

The usual main coals of the Allegheny formation are represented in this distriet-that is, the Upper and Lower Freeport and the Upper, Middle, and Lower Kittanning coals. These coals are also visible in the road sections in the surrounding hills. The distance between the highest and lowest of the five beds varies from 180 feet to about 210 feet, and, as usual, the Upper Kittanning bed occurs about midway between. A section of the lower part of the 
Allegheny was hand leveled by W. C. Phalen at Scalp Level, from the point where the trolley line crosses Paint Creek. This section is as follows:

Section of lower Allegheny rocks at Scalp Level, Somerset County, Pa.

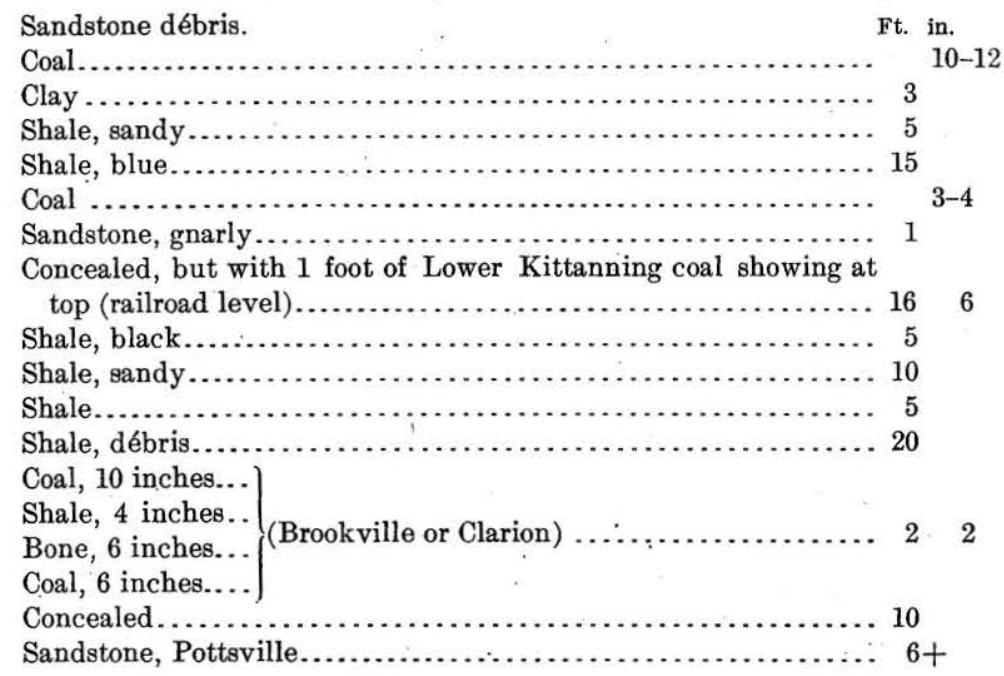

According to these measurements, the interval from the top of the Pottsville to the top of the Lower Kittanning (B) coal is about 70 feet, and the single coal which shows in the section may be the equivalent of the Brookville or Clarion beds. At Scalp Level, where Paint Creek passes over bluffs of the Pottsville formation, D'Invilliers ${ }^{a}$ noted a thin seam of coal 14 to 18 inches thick outcropping just above the water. This bed was not observed and may possibly be the representative of the other of these lower coals.

On the assumption that the average thickness of the Allegheny from the Lower Kittanning bed to the Upper Freeport, near Windber, is 180 feet and the interval from the top of the Pottsville to the Lower Kittanning is about 75 feet, the thickness of the Allegheny in this district is about 250 feet.

\section{ALLEGHENY COALS}

UPPER FREEPORT COAL.

The Upper Freeport (E) coal is the highest of the important coals outcropping in the hills surrounding Windber. It lies, according to barometric measurements, about 170 to 180 feet above the Lower Kittanning coal, and this interval remains fairly constant as far to the northeast as Elton, where drillings show it to be about 175 feet. Still farther northeast, toward South Fork of Conemaugh River, the inter- 
val increases to 200 feet. West of Stony Creek, in Somèrset County, according to the only available information, which has been procured from diamond-drill records, the interval is about 200 feet.

Little definite information was obtained as to the thickness of the Upper Freeport coal in this district, as no openings were located on it. The diamond-drill records northeast of Windber all indicate that it is workable, containing on an average about 3 feet of coal. It is known to be persistent-a fact which, in connection with a thickness of 3 feet, seems to place it among the future sources of supply in this region.

$$
\text { LOWER FREEPORT (D) COAL. }
$$

The Lower Freeport (D) coal is also persistent in this district; but little is known about it except from data furnished from drillings. Some of the records from points northeast of Windber show it to be in places 3 feet thick; others show less promising sections. It is possible that this bed may be valuable in the future; but the data obtained are insufficient to afford a basis for a positive opinion.

$$
\text { UPPER KITTANNING }\left(\mathrm{c}^{\prime}\right) \text { COAL. }
$$

The Upper Kittanning. (Cement or $\mathrm{C}^{\prime}$ ) coal about Windber lies practically midway between the Upper Freeport and Lower Kittanning beds. This is one of the most valuable coals about Wind-
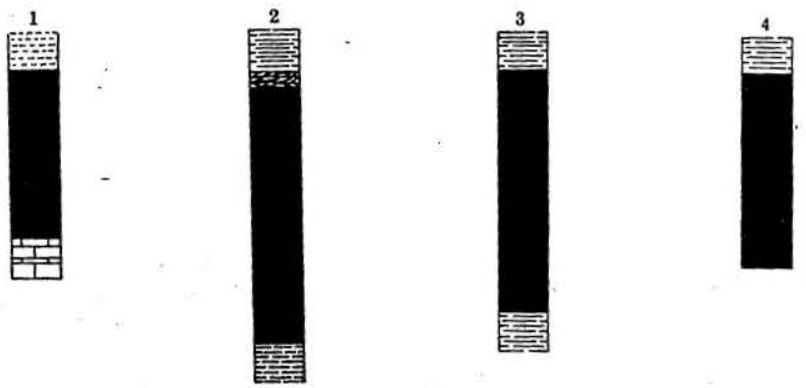

Frgure 16.-Sections of the Upper Kittanning (Cement or $\mathrm{C}^{\prime}$ ) coal in the Windber district. 1, Baltimore and Ohio Railroad south of quadrangle; 2, Stony Creek west of Ingleside; 3, east of Walsall; 4, head of Walsall Creek. Scale, 1 inch $=5$ feet.

ber. Though it is not worked on a commercial scale, something is known at least of its physical character from prospects on it in the region north of Windber, within the limits of the Johnstown quadrangle. In the description of this coal in the Johnstown district it was stated that it increased in thickness along Stony Creek, southward from Moxhom. As a matter of fact, the unusual thickness of 5 feet 6 inches prevails generally north of Windber; 6 feet has been measured one-half mile north of Eureka No. 37 and 5 feet 5 inches 1 mile north of the same mine. In both places the roof was black shale. (See also fig. 16.) 
Section 1 in figure 16 can not be regarded as strictly in the Windlier district, as it is on the west flank of the Ebensburg (Viaduct) axis, some miles above the mouth of Paint Creek. Sections 2 and 3 are taken from country banks near Windber. Section 4 may possibly be incomplete, as two sections measured about half a mile south and less than a mile west show very nearly 5 feet of coal in one and more than 5 feet in the other.

Enough is known of the coal in this district to be certain that it is of workable thickness. It may not average as thick as the above sections indicate, but an average of 4 to 5 feet in the hills north of Windber is probably a conservative estimate. Its quality is probably equal to that of the coal mined from this bed near Johnstown. (See p. 40.) In places the upper part of the coal bed is bony and will have to be discarded in mining. The roof is generally very firm shale.

MIDDLE KITTANNING COAL.

The next lower coal, the Middle Kittanning (C), is 25 to 30 fect above the Lower Kittanning bed. A few of the diamond-drill resords to the northeast of Windber show nearly 3 feet of coal in this bed. This thickness is exceptional. The coal may prove valuable in this district, but not enough is known about it to form a positive opinion.

LOWER KITTANNING COAL.

Name and position.-The Lower Kittanning (Miller or B) coal in the Windber district occurs, as stated above, at an interval of about - 170 to 200 feet below the Upper Freeport coal along the southern edge of the quadrangle. Immediately about Windber the interval is somewhat nearer the former than the latter figure. The coal outcrops well down in the hills about the town, permitting the operations to be conducted from the outcrop by drifts.

Extent and development.-The coal appears above drainage level on the eastern flank of the Ebensburg (Viaduct) anticline where this fold approaches the Wilmore Basin, near the southern edge of the quadrangle, and is present in the hills along Paint Creek westward to Stony Creek. The coal is above drainage level northward for some distance on Stony Creek, where the dip to the Johnstown Basin carries it below water level.

The operations on this bed of coal in the portion of the Windber district in this quadrangle are but a small part of the coal industry around Windber. As noted above, only two operations are conducted wholly within the Johnstown area-namely, Eureka Nos. 37 and 40 . 
Chemical character.-Analyses Nos. 30 to 32, pages 41-42, indicate the composition of the Lower Kittanning (Miller) coal about Windber. The analyses show its carbon content to be among the highest in the area, with a comparatively small amount of sulphir and ash.

Occurrence and physical character.-The sections in figure 17 illustrate the general section of the coal in the Windber district. The first two are the more representative, as they are more complete, showing the under coal characteristic of the Lower Kittanning (Miller) bed.

The main bench averages between $3 \frac{1}{2}$ and 4 feet of coal. A small rider, averaging 3 to 4 inches in thickness but varying from 1 to 14 inches, occurs from $3 \frac{1}{2}$ to 4 feet above the top of the main bench; it is noted in the Scalp Level section given on page 92 . There is also usually present an under coal lying from 3 inches to 2 feet below the
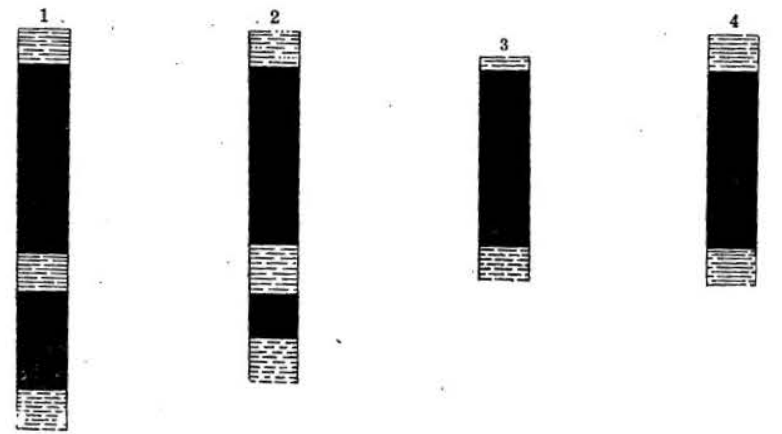

FIgURE 17.-Sections of the Lower Kittanning (Miller or B) coal in the Windber district. 1, Baltimore and Ohio Railroad south of quadrangle; 2, Berwind-White Coal Mining Company, Eureka No. 37, Windber; 3 , near south edge of quadrangle; 4 , near Walsall. Scale, 1 inch $=5$ feet.

main bench. This under coal ranges from 3 to 18 inches in thickness and may be very regular.

The roof is excellent and is either sandstone or sandy shale. It requires little or no timbering except where broken through. The partings in the coal are the usual "sulphur" lentils or balls, which are easily separated from the coal. Rolls are numerous and here and there the coal is completely pinched out. In places the slickensided surfaces associated with thin coal indicate movement akin to true faulting. The under clay is not worked in any of the mines, so far as known. The coal in the main bench is of the lustrous columnar variety.

LOWER ALLEGHENY COALS.

Though lower coals occur about Windber, they are too thin to be worked so far as known. Section showing the relations of these lower Allegheny coals are given on page 24. 


\section{CONEMAUGH FURNACE DISTRICT.}

EXTENT.

Along the west edge of the quadrangle, in the valley of Conemaugh River, the lower part of the Allegheny is brought down to drainage level by the steep dips along the western flank of the Laurel Ridge anticline. As the Allegheny or coal-bearing formation outcrops only along the river, the active mines are confined to the immediate river valley, and the district is small. Within the Johnstown area there are but two active mines - that of the Johnstown Coal Company and that of the Nineveh Coal Company. Both these concerns are working on the Lower Kittanning (Miller) bed. The dips carry this coal below drainage level just beyond the confines of the quadrangle, and farther west, in the town of Seward, it lies at a depth of 130 feet, as shown by the shaft of the Seward Coal Company.

\section{ALLEGHENY COALS.}

UPPER COALS.

But little definite information can be given regarding the three - highest coals in the Allegheny formation in this part of the qualrangle, for the reason that they have not been worked even on a small scale and few openings on them were found. It is known, however, that they are present in the hills north of Conemaugh River, outcropping along Trout Run, on which the Upper Freeport bloom was discovered. At this place a small opening, believed to be on the Upper Kittanning coal, showed the following section:

Section of Upper Kittanning coal on Trout Run.

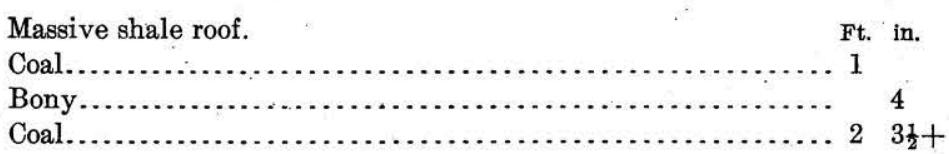

The Middle Kittanning is fairly persistent in this district and occurs about 40 feet above the Lower Kittanning (Miller) bed. Near Cramer this bed measured as follows:

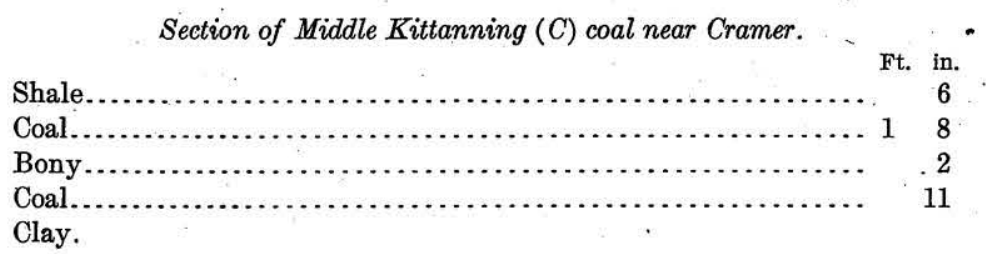

About Seward this coal measures 2 feet 6 inches. At Seward also the Lower Freeport (D) coal is reported as being about 2 feet thick, capped by 8 to 12 feet of shales mixed with sandstone slabs and underlain by 7 feet of bluish massive shales. The overlying shales are used in the manufacture of red building brick. 
LOWER KITTANNING (B) COAL.

Extent and development.-The only coal of commercial importance around Conemaugh Furnace at present is the Lower Kittanning (Miller) bed, and, as stated above, there are but two mines at which this coal is worked-that of the Johnstown Coal Company, on the north side of Conemaugh River, and that of the Nineveh Coal Company, on the south side of the river and on the main line of the Pennsylvania Railroad. The coal here lies about 65 to 70 feet above the top of the Pottsville formation. Farther west the coal goes below drainage level and is mined by shaft near Seward by the Seward Coal Company.

Chemical character.-A sample carload of coal from this bed, collected and shipped by J. W. Groves, of the United States Geological Survey, from a point on the Pennsylvania Railroad $1 \frac{1}{2}$ miles east of Seward, Westmoreland County, has been subjected to steaming, washing, coking, and briquetting tests, ${ }^{a}$ so that the character and behavior of the coal in this part of the quadrangle are known. Two mine samples were also collected for chemical analysis. The results of the chemical analyses are given on pages 41-42 (Nos. 33-35) and below:

Chemical analyses of Lower Kittanning coal from Conemaugh Furnace district.

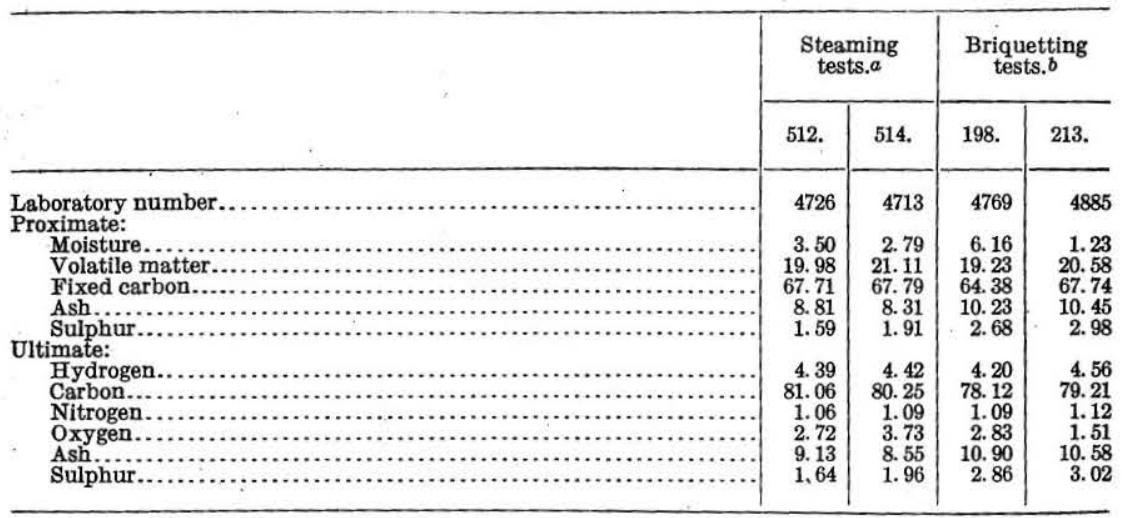

a Proximate analysis of fuel as fired; ultimate analysis of dry fuel figured from car sample. $b$ Proximate analysis of fuel as received; ultimate analysis on dry basis.

Only the proximate analyses are of interest in this connection, and these need but little comment. They show the usual high carbon characteristic of this coal in the Johnstown quadrangle, together with low volatile matter. The moisture is about the same as usual for this coal, though perhaps a trifle higher. Ash and sulphur are both higher than the average for this coal in the rest of the area.

$a$ Bull. U. S. Geol. Survey No. 332, 1908, pp. 216 et seq.

$69516^{\circ}-$ Bull. $447-11-7$ 
Steaming tests.-The steaming tests were not made on the coal itself but on briquets made from it, and the results are given in the table below. The weights of water evaporated from and at a temperature of $212^{\circ} \mathrm{F}$. per pound of dry fuel used-9.65 pounds in test 512 and 8.14 pounds in test 514 -indicate the standing of briquets made from this coal. The results should be compared with the results with first-class steaming coals given on page 37 .

Steaming tests on Lower Kittanning coal from the Conemaugh Furnace district.

\begin{tabular}{|c|c|c|}
\hline$\cdot$ & Test 512.a & Test $514 . b$ \\
\hline $\begin{array}{l}\text { Duration of test } \\
\text { Heating value of fuel. } \\
\text { Force of draft: }\end{array}$ & $\begin{array}{r}7.77 \\
14,495\end{array}$ & $\begin{array}{r}7.93 \\
14,382\end{array}$ \\
\hline Under stack damper.................... & 0.93 & 0.93 \\
\hline 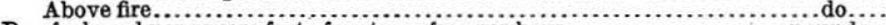 & .19 & .23 \\
\hline 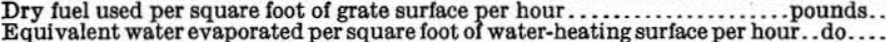 & $\begin{array}{r}19.93 \\
3.84\end{array}$ & $\begin{array}{r}27.52 \\
4.47\end{array}$ \\
\hline 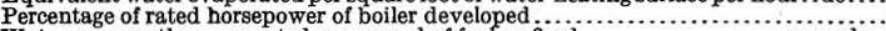 & 107.7 & 125. 3 \\
\hline $\begin{array}{l}\text { Water apparently evaporated per pound of fuel as fired........................ pounds.. } \\
\text { Water evaporated from and at } 212^{\mathrm{b}} \mathrm{F} .:\end{array}$ & 7.70 & 6.54 \\
\hline 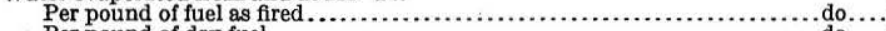 & 9. 32 & 7.91 \\
\hline 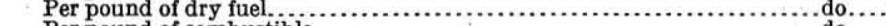 & 9.65 & 8. 14 \\
\hline 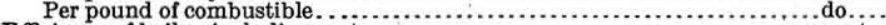 & 10.76 & 9.06 \\
\hline $\begin{array}{l}\text { Efficiency of boiler, including grate } \ldots \ldots \ldots \ldots \ldots \ldots \ldots \ldots \ldots \ldots \ldots \ldots \ldots \ldots \\
\text { Fuel as fired: }\end{array}$ & 64.29 & 54. 66 \\
\hline 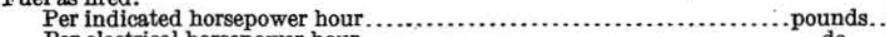 & 3.03 & 3.58 \\
\hline Per electrical horsepower hour................... & 3.75 & 4. 41 \\
\hline Dry fuel: & & \\
\hline 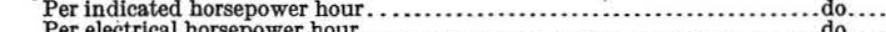 & 2.93 & 3. 47 \\
\hline 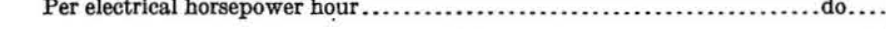 & 3.62 & 4.29 \\
\hline
\end{tabular}

$a$ Equal weights of briquets made from washed coal (briquetting tests 215 and 216, p. 100).

$b$ Equal weights of briquets (briquetting tests 208 and 209, p. 100).

Test 512 on briquets from tests 215 and 216 (equal weights); briquets burned freely, with intense heat and no smoke; 31 per cent clinker. Test 514 on briquets from tests 208 and 209 (equal weights); briquets burned freely, with intense heat and no smoke; 50 per cent clinker.

Coking tests.-The results of the coking tests on this coal are given below, together with analyses of the coal and resulting coke.

Coking tests on Lower Kittanning coal from Conemaugh Furnace district.

[Run-of-mine coal, finely crushed.]

\begin{tabular}{|c|c|c|c|}
\hline & - & $\begin{array}{l}\text { Test } 179 \\
\text { (raw). }\end{array}$ & $\begin{array}{l}\text { Test } 182 \\
\text { (washed). }\end{array}$ \\
\hline $\begin{array}{l}\text { Duration of test. } \\
\text { Coal charged..... }\end{array}$ & (n) pours.. & $\begin{array}{r}68 \\
13,070 \\
8,129\end{array}$ & $\begin{array}{r}78 \\
11,760 \\
7,350\end{array}$ \\
\hline Coke produced... & 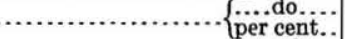 & $\begin{array}{l}8,129 \\
62.20\end{array}$ & $\begin{array}{l}7,350 \\
62.50\end{array}$ \\
\hline Breeze produced & $\left\{\begin{array}{l}\text { pounds... } \\
\text { per cent.. }\end{array}\right.$ & $\begin{array}{r}420 \\
3.21\end{array}$ & $\begin{array}{r}529 \\
4.50\end{array}$ \\
\hline Total yield....... & ............. & 65.41 & 67.00 \\
\hline
\end{tabular}

Test 179 yielded soft, dense coke light gray and silvery in color, with high ash and sulphur. Test 182 yielded soft, dense coke gray in color. Ash and sulphur were reduced by washing. There was no improvement in physical appearance. 
Analyses.

\begin{tabular}{|c|c|c|c|c|}
\hline \multirow[t]{2}{*}{ 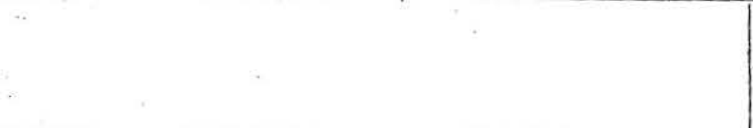 } & \multicolumn{2}{|c|}{ Test 179.} & \multicolumn{2}{|c|}{ Test 182.} \\
\hline & Coal. & Coke. & Coal. & Coke. \\
\hline 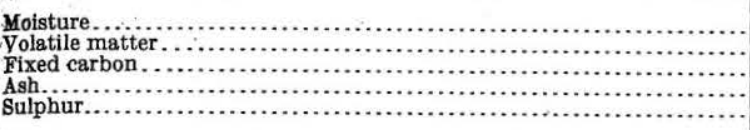 & $\begin{array}{r}3.91 \\
16.35 \\
68.30 \\
11.44 \\
2.78\end{array}$ & $\begin{array}{r}0.30 \\
.28 \\
84.95 \\
14.47 \\
2.31\end{array}$ & $\begin{array}{r}6.30 \\
17.04 \\
69.58 \\
7.08 \\
1.34\end{array}$ & $\begin{array}{r}0.51 \\
89.58 \\
9.85 \\
9.06 \\
1.11\end{array}$ \\
\hline
\end{tabular}

Washing tests.-Results of washing tests are given below. The figures indicate that finer crushing is advantageous. The loss of "good coal" (by which is meant all coal of a quality equal to or better than that of the washed coal) in the refuse will not exceed 2 per cent.

Float and sink tests on Lower Kittanning coal from Conemaugh Furnace district. ${ }^{a}$

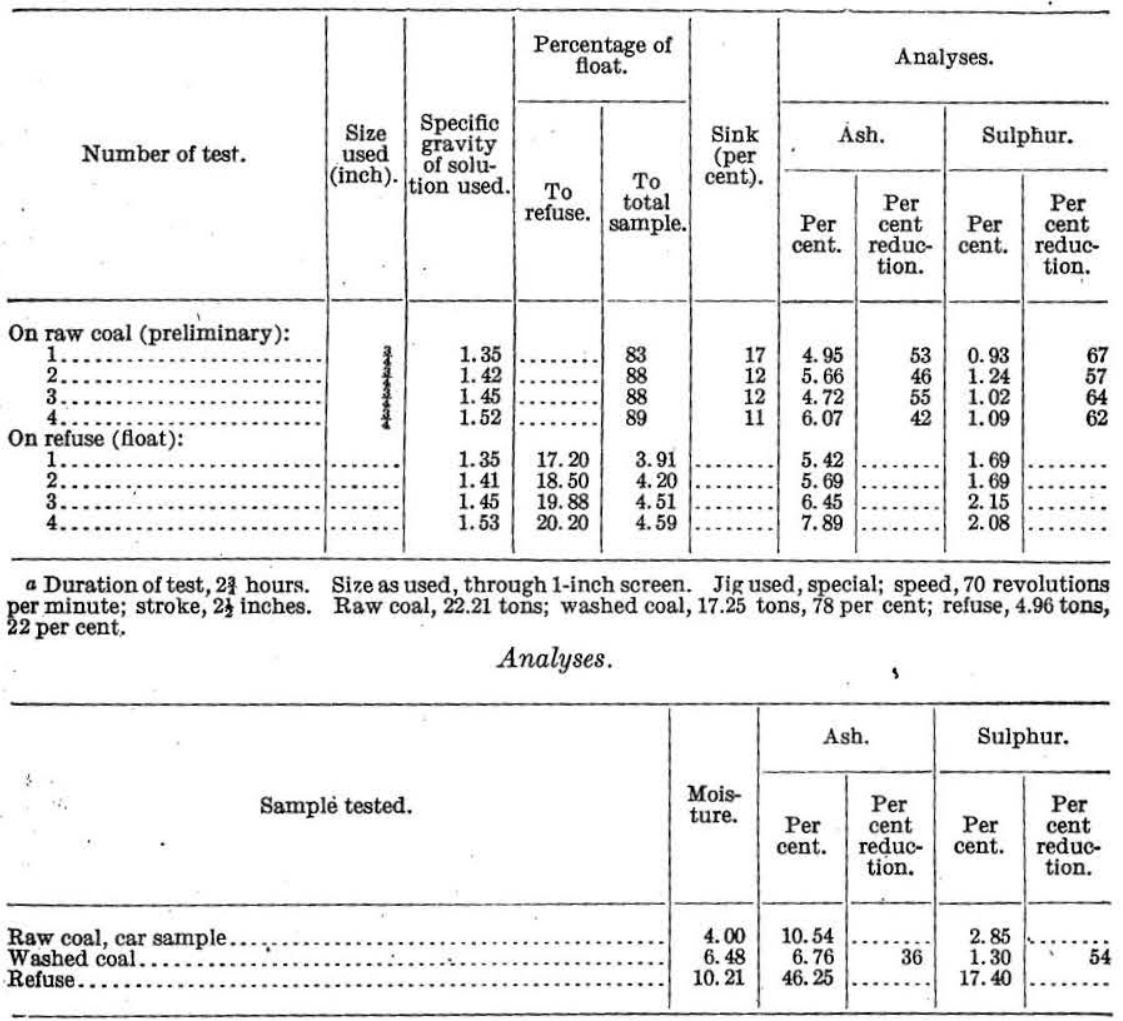

Briquetting tests.-Seven briquetting tests were made, three on raw and four on washed coal. Briquets from both the English and the Renfrow (American) machines had similar appearance, with smooth, hard surface, were very brittle, and broke with a glossy fracture and 
sharp edges. The percentage of binder (water-gas pitch) seemed to have little effect on brittleness, although Renfrow briquets with 8 per cent binder were handled with less breakage. There was no noticeable difference between the briquets made from raw and those from washed coal.

For analyses of coal used in briquets see page 97 (those from briquetting tests 208 and 209 under steaming test 514 ; from briquetting tests 212,215 , and 216 under steaming test 512).

Briquetting tests on run-of-mine coal from Conemaugh Furnace district.

[Water-gas pitch binder.]

\begin{tabular}{|c|c|c|c|c|c|c|c|}
\hline & $\begin{array}{l}\text { Test } \\
198 .\end{array}$ & $\begin{array}{l}\text { Test } \\
208 .\end{array}$ & $\begin{array}{l}\text { Test } \\
209 .\end{array}$ & $\begin{array}{l}\text { Test } \\
212 .\end{array}$ & $\begin{array}{l}\text { Test } \\
213 \text {. }\end{array}$ & $\begin{array}{l}\text { Test } \\
215 \text {. }\end{array}$ & $\begin{array}{l}\text { Test } \\
216 .\end{array}$ \\
\hline 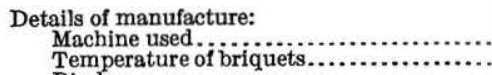 & $\begin{array}{r}\text { Eng. } \\
158\end{array}$ & $\begin{array}{r}\text { Renf. } \\
158\end{array}$ & $\begin{array}{r}\text { Renf. } \\
158\end{array}$ & $\begin{array}{r}\text { Renf. } \\
158\end{array}$ & $\begin{array}{r}\text { Renf. } \\
158\end{array}$ & $\begin{array}{r}\text { Eng. } \\
176\end{array}$ & $\begin{array}{r}\text { Eng. } \\
176\end{array}$ \\
\hline 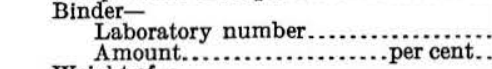 & $\begin{array}{r}4683 \\
6\end{array}$ & $\begin{array}{r}4683 \\
7\end{array}$ & $\begin{array}{r}4683 \\
8\end{array}$ & $\begin{array}{r}4683 \\
7\end{array}$ & $\begin{array}{r}4683 \\
8\end{array}$ & $\begin{array}{r}4683 \\
6\end{array}$ & $\begin{array}{r}4683 \\
7\end{array}$ \\
\hline 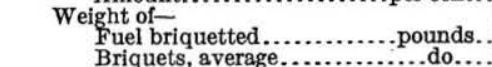 & $\begin{array}{r}3,200 \\
3.52\end{array}$ & $\begin{array}{l}4,500 \\
0.451\end{array}$ & $\begin{array}{l}8,000 \\
0.457\end{array}$ & $\begin{array}{l}6,500 \\
0.427\end{array}$ & $\begin{array}{l}6,500 \\
0.458\end{array}$ & $\begin{array}{r}6,400 \\
3.63\end{array}$ & $\begin{array}{r}3,300 \\
3.44\end{array}$ \\
\hline $\begin{array}{l}\text { Heat value per pound- } \\
\text { Fuel as received. }\end{array}$ & & & & & & & \\
\hline $\begin{array}{l}\text { Fuel as received........ } \\
\text { Fuel as fired.......... }\end{array}$ & $\begin{array}{l}13,347 \\
13,198\end{array}$ & $\begin{array}{l}13,347 \\
13,981\end{array}$ & $\begin{array}{l}13,347 \\
13,981\end{array}$ & 14,639 & $\begin{array}{l}14,639 \\
13,896\end{array}$ & $\begin{array}{l}14,639 \\
13,988\end{array}$ & $\begin{array}{l}14,639 \\
13.988\end{array}$ \\
\hline Binder .................................. & 16,637 & 16,637 & 16,637 & 16,637 & 16,637 & 16,637 & 16,637 \\
\hline 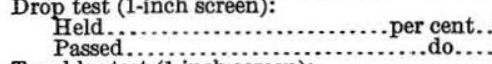 & $\begin{array}{l}74.8 \\
25.2\end{array}$ & $\begin{array}{l}19.5 \\
80.5\end{array}$ & $\begin{array}{l}26.0 \\
74.0\end{array}$ & $\begin{array}{l}23.0 \\
77.0\end{array}$ & $\begin{array}{l}19.5 \\
80.5\end{array}$ & $\begin{array}{l}74.6 \\
25.4\end{array}$ & $\begin{array}{l}71.9 \\
28.1\end{array}$ \\
\hline 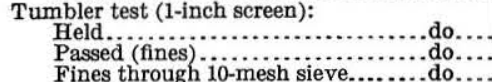 & $\begin{array}{l}71.0 \\
29.0 \\
65.4\end{array}$ & $\begin{array}{l}54.0 \\
46.0\end{array}$ & $\begin{array}{r}61.5 \\
38.5\end{array}$ & $\begin{array}{r}67.0 \\
33.0\end{array}$ & $\begin{array}{l}64.0 \\
36.0\end{array}$ & $\begin{array}{l}74.0 \\
26.0\end{array}$ & $\begin{array}{r}70.5 \\
29.5 \\
-7.5\end{array}$ \\
\hline $\begin{array}{l}\text { Fines through 10-mesh sieve..........do.... } \\
\text { Water absorption: }\end{array}$ & 65.4 & 86.8 & 86.4 & 91.6 & 87.3 & 63.2 & 70.4 \\
\hline 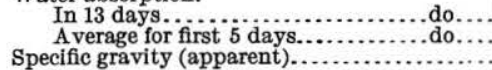 & $\begin{array}{r}14.5 \\
2.34 \\
1.141\end{array}$ & $\begin{array}{l}15.5 \\
2.78 \\
1.11\end{array}$ & $\begin{array}{r}15.0 \\
2.66 \\
1.127\end{array}$ & $\begin{array}{r}19.0 \\
3.1 \\
1.043\end{array}$ & $\begin{array}{r}14.5 \\
2.50 \\
1.144\end{array}$ & $\begin{array}{r}9.5 \\
1.56 \\
1.148\end{array}$ & $\begin{array}{r}11.0 \\
1.56 \\
1.121\end{array}$ \\
\hline
\end{tabular}

Tests 198, 208, and 209. Size used: Over $\frac{1}{2}$ inch, 0.8 per cent; io inch to $\frac{1}{4}$ inch, 3.6 per cent; $\frac{x}{20}$ inch to id inch, 11.2 per cent; $\frac{1}{80}$ inch to $\frac{1}{2}$ inch, 27 per cent; through to inch, 57.4 per cent.

Tests $212,213,215$, and 216 (on washed coal). Size as used: Over $\frac{1}{2}$ inch, 0.8 per cent; $\frac{1}{10}$ inch to $\frac{1}{3}$ inch, 4.8 per cent; $\frac{1}{20}$ inch to $\frac{1}{10}$ inch, 16 per cent; to inch to $\frac{1}{20}$ inch, 26 per cent; through to inch, 52.4 per cent.

Extraction analyses.

\begin{tabular}{|c|c|c|c|c|c|c|}
\hline \multirow[b]{2}{*}{$\therefore$} & \multirow{2}{*}{ Pitch. } & \multirow{2}{*}{ Fuel. } & \multicolumn{4}{|c|}{ Briquets. } \\
\hline & & & $\begin{array}{l}\text { Test } \\
198 .\end{array}$ & $\begin{array}{c}\text { Tests } \\
208,209 .\end{array}$ & $\begin{array}{l}\text { Test } \\
213 .\end{array}$ & $\begin{array}{c}\text { Tests } \\
215,216 \text {. }\end{array}$ \\
\hline 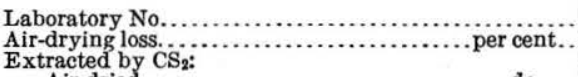 & 4683 & $\begin{array}{l}4498 \\
3.10\end{array}$ & $\begin{array}{l}4769 \\
5.50\end{array}$ & $\begin{array}{l}4713 \\
2.00\end{array}$ & $\begin{array}{l}4885 \\
0.60\end{array}$ & $\begin{array}{l}4726 \\
3.10\end{array}$ \\
\hline 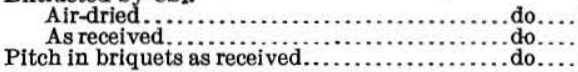 & 89.31 & $\begin{array}{r}1.02 \\
.99\end{array}$ & $\begin{array}{l}5.60 \\
5.29 \\
5.00\end{array}$ & $\begin{array}{l}6.86 \\
6.72 \\
6.49\end{array}$ & $\begin{array}{l}8.03 \\
7.98 \\
7.92\end{array}$ & $\begin{array}{l}6.90 \\
6.61 \\
6.37\end{array}$ \\
\hline
\end{tabular}


Occurrence and physical character.-The sections in figure 18 indicate the thickness of the Lower Kittanning coal, its under benches, and the character of its roof and floor in the Conemaugh Furnace
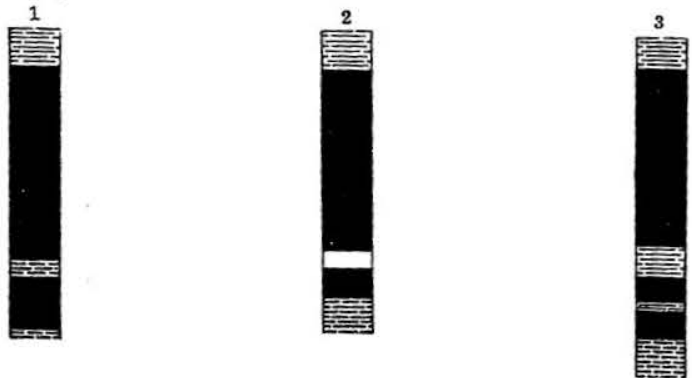

FiguRE-18.-Sections of the Lower Kittanning (Miller or B) coal in the Conemaugh Furnace district. 1, 2, Johnstown Coal Company, north of Conemaugh River; 3, Nineveh Coal Company, Seward mine, south bank of Conemaugh River. Scale, 1 inch $=5$ feet.

district. In addition to the sections shown in the figure, the following were measured:

Section of Lower Kittanning coal on Laurel Ridge, near Cramer.

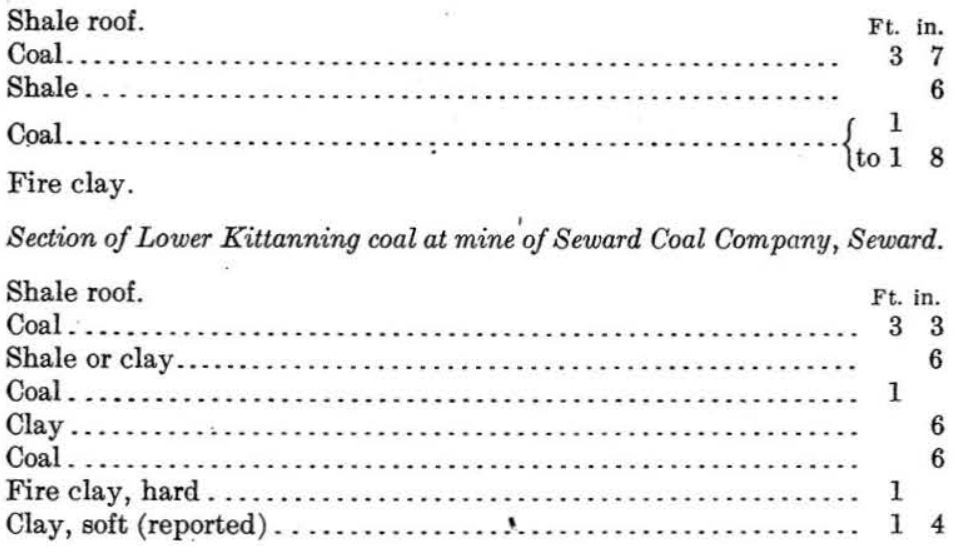

The coal near Conemaugh Furnace and Seward is comparable in every way with the corresponding coal as mined farther east near Johnstown, South Fork, Blacklick Creek, and Windber. In this particular district the bed was measured and studied in three mines and seen at one country bank. The main bench ranges from 3 feet 3 inches to 3 feet 9 inches. Below this, one and in places two lower benches are found. The first ranges in thickness from 6 to 20 inches and is separated from the main bench by a shale parting usually not more than 6 inches thick; this bench is used at Seward by the brick company to burn bricks. The second lower bench is about 6 inches thick, and the underlying clay is reported as thick as 17 feet, only 6 feet of which is considered of brickmaking grade. The roof of the coal is firm shale and the usual rolls in the floor are present. 
COAL MINING.

Two general systems of working coal were employed in the Johnstown quadrangle when this work was done-the room and pillar system and the long-wall system. The former is in most common use, but two of the mines along Blacklick Creek (Nos. 1 and 3 of the Vinton Colliery Company) have used the long-wall system.

ROOM AND PILLAR SYSTEM.

General description.-The diagram or plan of the workings of one of the mines in the quadrangle given in figure 19 conveys some idea of the methods generally employed in the room and pillar method of mining coal.

Most of the mines in the quadrangle are drift mines and work coal which averages between 3 and 4 feet in thickness. For this reason, in the headings where hauling is done the roof is generally removed so as to allow between 5 and $5 \frac{1}{2}$ feet above the rail or nearly 6 feet in the clear. The main heading is usually driven straight and is cut through rolls, which are very common in the Lower Kittanning (Miller) coal, the most important bed of the area. If the rolls are too pronounced, however, the main heading may be curved around them.

The main entry or heading is usually run about 10 feet wide; in some mines it is as narrow as 9 feet and in a few as wide as 12 feet; in still others the width of the main headings ranges from 18 to 25 feet, but in such mines the rock is gobbed underground. Wide headings are not usual. The main airways appear to be about as wide as the main headings, and the pillar left between the two averages about 50 feet.

Cross or side headings are run from the main headings either at a considerable inclination or at right angles. The width of the cross headings varies but is commonly about 15 to 18 feet. One mine at South Fork reported cross headings only 7 to 8 feet wide. A few mines near Johnstown reported cross headings as broad as 21 and 24 feet, but here it is possible that much of the rock may be gobbed underground. About South Fork some of the larger mines reported cross headings 550 feet apart. In turning rooms from the cross headings the turn may be about 9 feet long and 15 feet wide, but the practice may vary considerably from these figures.

The dimensions of rooms vary within narrow limits. The width ranges from 21 to 40 feet; 24-foot rooms are very common, but those in excess of 30 feet are rare. About South Fork the roof of the Lower Kittanning (Miller) coal has caused trouble in places, and some rooms have been lost on account of running them too wide; in the mines where this difficulty was encountered a 2 r-foot room with 15 to 20 foot pillars has given the best satisfaction. The length of the 
COAL MINING.

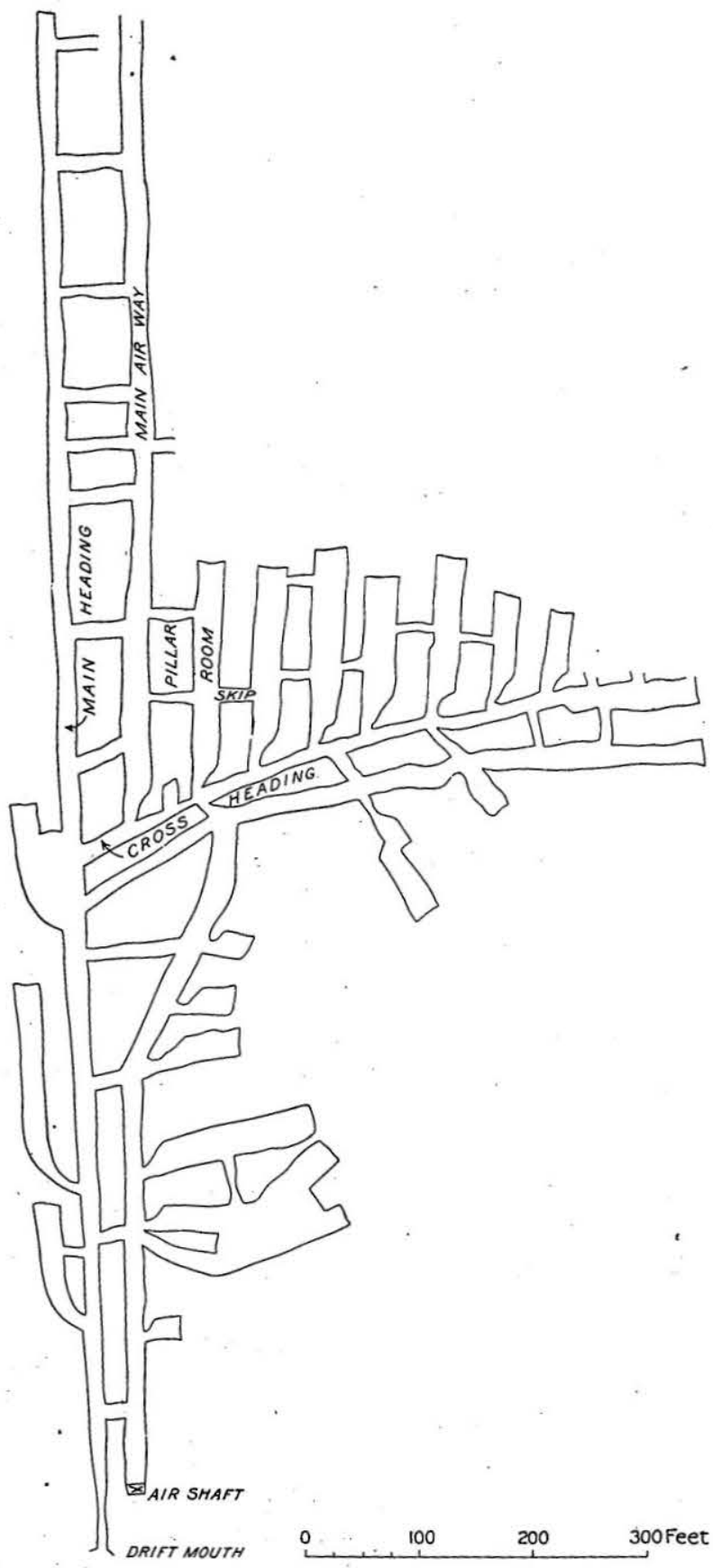

FIGURE 19.-Diagram illustrating room and pillar method of mining in Johnstown quadrangle. 
rooms in the larger mines is usually 300 feet, but ranges from 225 to 360 feet, the latter length being fairly common near South Fork and along Blacklick Creek. In many of the smaller mines the length of rooms is less than 100 feet.

The width of pillars between rooms is generally 30 feet, but in some of the mines where the covering is unusually heavy more pillar has to be left, and at South Fork some of the larger mines report 34 to 36 foot pillars. As stated above, a 15 to 20 foot pillar gives the best satisfaction in certain mines. Pillars 27,24 , and 21 feet wide are also used at a few mines. A 60 -foot pillar was reported from a couple of mines. A "skip" is a crosscut between two adjacent rooms. Its length, of course, is the width of a pillar; its width varies from 10 to 20 feet. Pillars are worked back from the room face within 60 feet of the cross headings until all the rooms in the cross headings are worked out. The roof is allowed to cave after the coal is worked out.

The methods of ventilation, drainage, and haulage of coal to the surface, together with the mining methods employed, vary widely. Some of the mines in the quadrangle are among the largest in the State and employ hundreds of men. Such mines have extensive underground workings and employ the most elaborate and expensive systems to insure the safety of the lives of the men and the cheapest and most expeditious means of transferring coal from mining breasts to coal cars. At Windber, for instance, machine mining is practiced almost altogether at Eureka No. 37, compressed-air machines being used. Hauling is done by electricity and ventilation by fans. The drainage is natural and by pump. Of Eureka No. 40 mine, which is the latest in the Windber territory, J. T. Evans, mining inspector of the sixth bituminous district of Pennsylvania, says: "It will be the model mine of the district."

Ventilation.-Ventilation is effected by natural methods, furnace and stack, or fan. In the smaller mines the first two methods are in common use, but in the larger mines fan ventilation has to be employed. The variety of the fans used is great; the size of fan and the number of revolutions made per minute depend entirely on local coditions. The motive power used in driving the fans is compressed air, electricity, steam, etc.

Drainage.-Drainage is either natural or artificial. In most of the smaller mines and in some of the larger workings natural drainage is used. Artificial drainage is accomplished by pumps driven by compressed air, steam, or electricity; hand pumps are also used.

Haulage.-In the smaller mines both hand haulage and mule haulage are employed. In the larger mines mule haulage is used almost exclusively as an auxiliary; the mules haul the loaded mine 
cars to the foot of slopes or planes or to the electric tramways, and the loaded cars are hauled out by wire ropes or electric locomotives. The overhead-trolley system is in common use and at South Fork the third-rail system is used in one of the mines.

Tipples are of various makes. The old-fashioned cradle tipple is still the most popular, but an automatic dump is used at some of the larger mines at South Fork and on Blacklick Creek, a crossover patent in at least two mines on Blacklick Creek, and a kind of rotary tipple at one mine in the Blacklick Creek district. At the Conemaugh slope the coal is dumped at the mine mouth into buckets of 1,000 pounds capacity, which are then conveyed by electric power from the north side of Conemaugh River over the Pennsylvania Railroad to the Franklin plant of the Cambria Steel Company.

Mining methods.-The mining methods employed in the Johnstown quadrangle are hand or pick mining and machine mining. In some of the larger mines machines are used almost exclusively, but as a general thing a combination of pick and machine mining is found more satisfactory.

\section{LONG-WALL SYSTEM.}

The conveyor method of the long-wall system of mining coal has been used at collieries Nos. 1 and 3 of the Vinton Colliery Company at Vintondale, in the Blacklick Creek district (fig. 20). It has been abandoned for some years in this district. The long-wall system is the one most commonly used in the coal mines of Europe, where it is regarded as being much more economical of the coal than the room and pillar method. For this reason it was recommended in the report to the Secretary of the Interior by Messrs. Watteyne, Meissner and Desborough, ${ }^{a}$ the three foreign experts recently selected for the investigation of mine explosions in the United States. The long-wall system has a number of modifications, that used in the Blacklick Creek district and commonly referred to as the conveyor method being one of them. Figures 21 and 22 illustrate the method as formerly practiced at Vintondale. The coal bed worked is the Lower Kittanning (Miller or B) bed. It usually runs 3 feet 6 inches thick near Vintondale, and its maximum and minimum thickness may be taken as 3 feet 10 inches and 3 feet 3 inches, respectively. Below the main bench, from which it is separated by 8 to 10 inches of shale, is a coal ranging from 2 to 10 inches in thickness. The roof of the coal is hard shale and is a most excellent cover, though it has marked slips or crevices. The coal is bound very tightly to both roof and floor. The average thickness of the cover is about 180 to 200 feet. The territory of the mines is long and narrow, and this, together with the 
106 MINERAL RESOURCES OF JOHNSTOWN, PA., AND VICINITY.

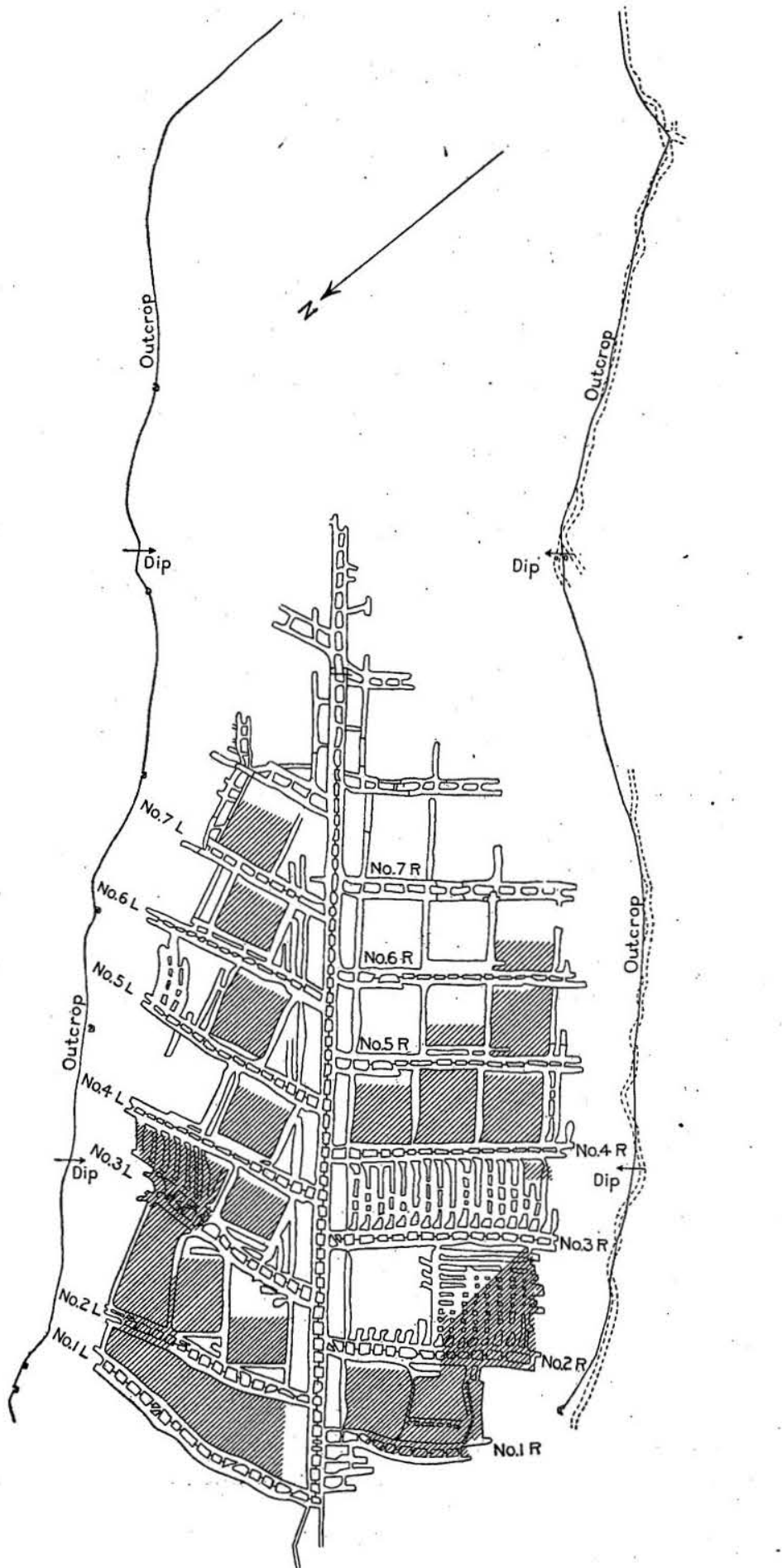

FIGURE 20.-Plan showing long-wall method of mining as employed at Vinton collieries Nos. 1 and 3 , Vintondale. 
heavy pitch of the coal (see Pl. I), makes the successful working of the bed by the room and pillar method difficult. ${ }^{a}$

The long-wall method as first practiced at Vintondale differs somewhat from the method used there later. At the beginning of the operations in this region the faces of the coal were worked by passing the mine cars at one end of the face, along the face, and out at the opposite end when loaded. The results were only fair, as the roof and the steep grades both gave trouble. In the other mines working at Tintondale at this time no marked slips or cracks in the roof had been noticed and it was naturally inferred that these conditions would.prevail generally; but after the long-wall faces had been in

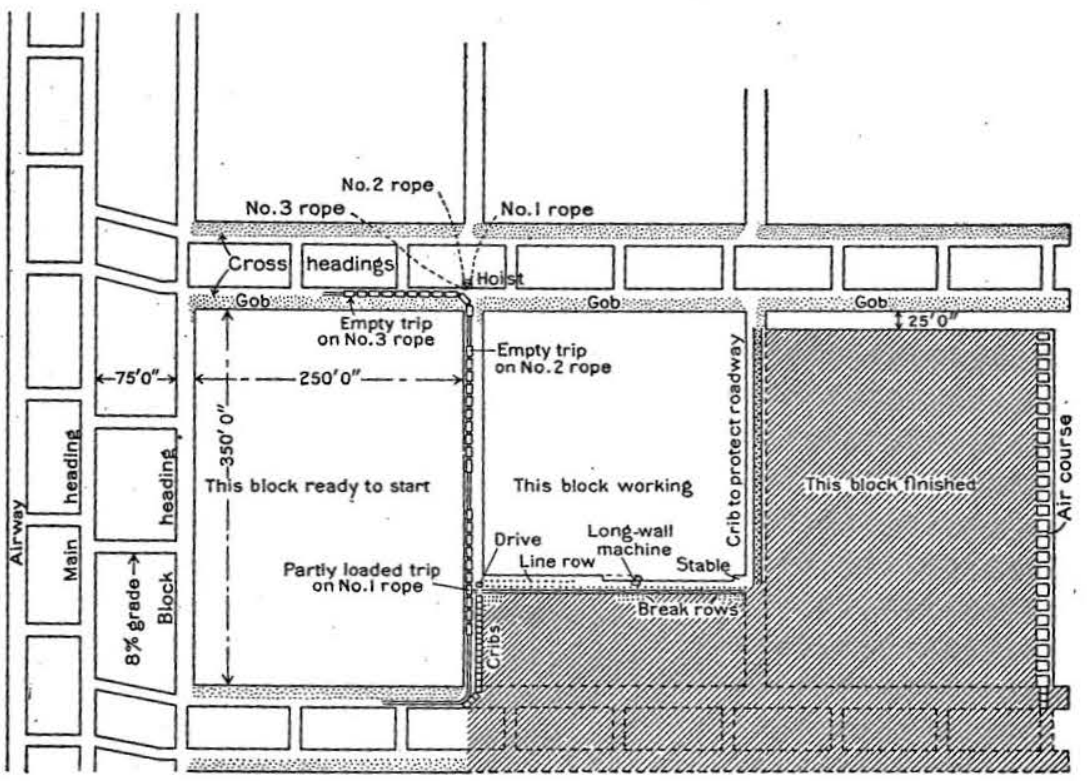

FrGURE 21.-Plan of workings, single long-wall conveyor system. (From an article by J. I. Thomas in Mines and Minerals, November, 1907, pp. 200-203. Reproduced by permission.)

operation for some time marked slips were encountered almost exactly in line with the face of the coal, and it was found very difficult to keep the roadway open when these slips occurred at the working face.

Another reason for abandoning this method of working was the difficulty of controlling mine cars on the heavy grades. Not only wrecks but delays were caused by mine cars getting beyond the working faces. If the roof conditions had been more favorable, the proposed method of working would have made, with slight modifications, an excellent arrangement for the use of the conveyor system. ${ }^{b}$

a A description of the method of mining the coal in this region was read by Mr. Clarence $\mathrm{R}$. Claghorn at the February, 1900, meeting of the North of England Institute of Mining and Mechanical Engineers (Trans. Inst. Min. Eng., vol. 18, 1900, pp. 351 et seq.).

b Ware, R. G., Trans. Inst. Min. Eng., vol. 29, 1906, pp. 462-474. 
To overcome the delays and difficulties, C. R. Claghorn proposed that a conveyor should be installed along the long-wall faces and that the mine cars should be run on a semipermanent road under the head end of the conveyor and there loaded instead of being passed along the face. From the first the conveyor was a success.

The following descriptions of the working methods at Vintondale are by Mr. J. I. Thomas, assistant, superintendent of the Vinton collieries ${ }^{a}$ when the field work on the report was done:

The block work, which is a modification of long-wall mining, was first started in the No. 3 mine of this company seven years ago. At the outset cars were run around the working face and loaded. This method brought only fair results owing to the necessity of using small cars, steep grades, and difficulty in keeping roadways open. Arrangements were then made for the placing of a conveyor along the face, allowing the curs to be run under the head end to be loaded.

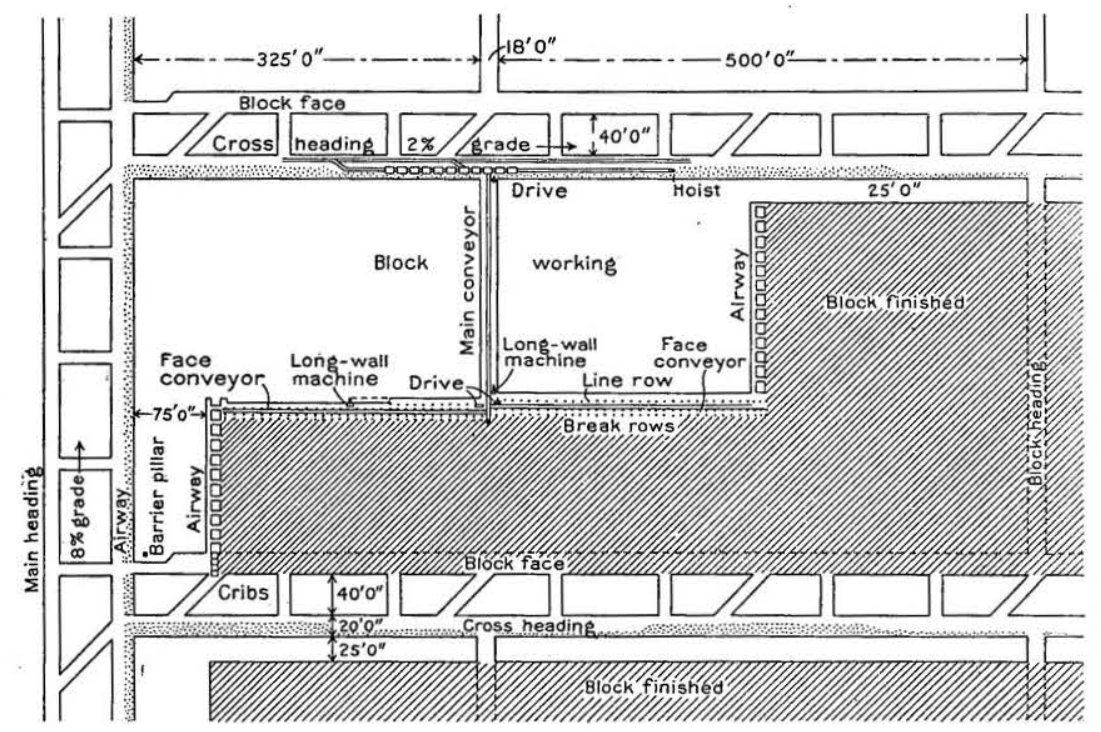

Figure 22.-Plan of workings, triple long-wall conveyor system. (From an article by J. I. Thomas in Mines and Minerals, November, 1907, pp. 200-203. Reproduced by permission.)

The first conveyor, which was made entirely of wood, was a cumbersome affair and much time was consumed in moving it laterally along the face after the cut had been loaded out, but after a year's trial the results obtained were so gratifying that metal conveyors were designed and ordered and preparations were made to employ this system on a much larger scale.

The conveyor system is very flexible and numerous methods of working are applicable, as the condition of the territory demands.

In Vintondale, at present, there are two different arrangements-that is, the single conveyor method, which has been mentioned, and the triple-conveyor system, by which two face conveyors dump alternately into a third conveyor, which in turn dumps into the mine cars. Both air and electricity are used as the driving power.

a Coal Min. Inst. America, June meeting, 1907. Mine and Quarry, vol. 2, No. 3, February, 1908, pp. 193 et seq. Mines and Minerals, November, 1907, pp. 200-203. 
In the No. 3 mine, where the single-conveyor system is being used with compressed air as power, the main heading and air course are driven up the pitch through the center of the property. Cross headings are driven off the main at intervals of 400 feet and run to the outcrop. These headings are 20 feet wide, with an 8-foot roadway carried next to the pillar, which is 40 feet thick. Barrier pillars of 75 -foot thickness are maintained on each side of the main entries. Block headings are driven perpendicularly off the cross entries at 265 feet centers. This allows a solid face of 250 feet. These block headings are driven 15 feet wide, but bottom is lifted only 7 feet wide near the rib and of such depth to allow a clearance of 6 feet from the top of rail. The remaining width acts as a shelf for the support of the drive and long-wall machine. As the block headings are driven for a distance of 350 feet into the solid coal, it is found necessary to carry along a good line of bratticing for the purpose of ventilation.

The block nearest the outcrop is first attacked. On this block it is necessary to maintain an areaway at the rear end. This is done by driving along with the block a place 4 feet wide, leaving a pillar 10 feet thick between it and the edge of the block. The coal is extracted to within 25 feet of the upper heading, when the conveyor is removed to the next block, which is worked out in the same manner; and so on until the coal in the whole tier of blocks is recovered. In the meantime the pillar left by the block and the chain pillars are being mined by hand. The time consumed in removing equipment from one block to another is usually about fifteen hours.

The type of conveyor consists of a trough or pan made of sheet steel one-eighth inch thick, 12 inches wide at the bottom, 18 inches wide at the top, and 6 inches high, set on strap-iron standards. The conveyor, which is 250 feet in length, is made up in sections of $6,12,15$, and 18 foot lengths, connected together by means of one-half inch flat-headed bolts, countersunk. The front is inclined for a distance of 45 feet to allow clearance for mine cars to pass under. The rear end is inclined for 15 feet to compensate for the size of sprocket wheel. A return runway for the chain is afforded below the pans by angle irons.

A cast-iron driving sprocket 18 inches in diameter and 13-inch face is attached to the front end. On the shaft of this sprocket, which is extended 12 inches beyond one of the bearings, is keyed a 12-tooth 16-inch diameter sprocket, which connects with the driving mechanism. The rear-end section consists of a framework made up of two I-beams, 6 feet long and strongly braced, on which rest the take-up boxes for keeping the chain in adjustment and the rear sprocket wheel over which the chain returns.

The conveyor chain is made of either steel or malleable cast iron, held together by bolts, the ends of which may be riveted or fitted with nuts. As it is impracticable to secure a chain that will not break, they are designed so that repair can be made expeditiously.

The power is carried to the different machines by means of a 2-inch pipe, which is run from the main supply along the lower heading to the top of the block heading. A connection is here made with the hoisting engine. The line is carried on props down the block heading to the conveyor, where it is connected by means of a $2 \frac{1}{2}$-inch wire-wound rubber hose to a 2 -inch pipe that runs the entire length of the block and attached to the conveyor. This pipe has outlets with 2-inch stopcocks at intervals of 50 feet, to which the hose of the mining machines and air drills may be attached. This arrangement necessitates carrying only a short length of hose on these machines instead of one reaching the whole length of the block.

From the end of the conveyor a $1 \frac{1}{1}$-inch pipe is run to the air engine. In this pipe is a valve, which is connected to a rod that reaches to the head end of the conveyor. It is from this point that the conveyor is controlled when running. As the air line needs to be shortened 5 feet nearly every day, several sections of different lengths are kept near at hand, so that this change can be quickly made.

The cars are handled to the conveyor by means of a double cylinder, with an 8 by 10 inch double friction-drum hoisting engine. The drums work loose on the shaft 
independent of each other and are equipped with a powerful differential brake that will hold any load the engine will hoist; 500 feet of $\frac{5}{8}$-inch rope is reeled on each drum. A small hand drum, on which is reeled 150 feet of $\frac{1}{2}$-inch rope, is used to lower the cars around the curve.

The cars are dropped into the lower heading from the main haulage and pulled, either with mules or a small engine, to the top of the block heading. Here the rope of the small drum is attached to the coupling between the first and second car and the cars pushed around the curve. One of the ropes of the hoist is now attached to the rear end of the trip, which is usually ten cars, and the small rope is freed. The trip is then dropped to the conveyor to be loaded. Another trip is attached to the other rope of the hoist in the same manner. This trip is held on the block entry until the first trip is loaded. This having been accomplished, the loaded trip is dropped to the bottom of the block heading and the rope disengaged. The driver here takes the cars and hauls them to the main haulage. The rope is then pulled to the top of the block heading and attached to the cars, as described. ' In the meantime the empty trip on the block heading has been dropped to the conveyor and started to be loaded. This change usually occupies two to three minutes. Electric signal wires are run the length of block headings, by which the head man signals the engine boy.

The drive, which is a small double-cylinder engine with reduced gearing, is mounted on a frame and attached to the conveyor. The power is transmitted by means of a steel thimble roller chain to the sprocket on the drive shaft of the conveyor.

The drill used for boring the holes is an ingenious tool; the weight of auger and drill does not exceed 20 pounds. The machine is a small four-cylindered air engine and has a gear on the shank of the machine. The auger is attached to a small chuck that is screwed on to the end of the shank. A hose three-eighths inch in diameter and 50 feet long, attached to the conveyor pipe, furnishes the power for the drill.

The complement of men required to run a block is 13-that is, block boss, machine runner and helper, driller, who also acts as shot firer, engine boy, head man, and six loaders.

The "block boss," or leader of the crew, has direct charge of the block: He must be a man who has some knowledge of mining and the care of machinery, and must possess good executive ability. The balance of the crew, with the possible exception of machine men, are generally non-English-speaking men.

In preparation for the day's work the machine has cut one rail (30 feet) on the previous afternoon. In the morning this coal is shot down and the loaders begin work inmediately. It requires from four and one-half to five hours for the machine men to finish the cut. The machine is then overhauled and moved up in position to start the return cut. After finishing their own work the runner and his helper go back on the block and make preparations for the moving of the conveyor. This consists of setting a line of props, called the line row, about 8 feet apart, and a distance from the conveyor equal to the depth of the undercut. As these are placed the old line row; which is now against the conveyor, is withdrawn. The pulling jacks for moving the conveyor are distributed along the block 40 feet apart and placed in position.

The shot firer keeps closely after the machine, and is through shooting shortly after the undercut is finished. He then starts from the far end of the block to drill holes in the new face. It usually takes him about two hours daily to drill the entire width of the block.

Each loader is supplied with a pick and shovel and a piece of sheet iron 9 inches wide and 6 feet long, which he attaches to the conveyor to act as a side board. As each loader cleans up his place he moves forward to the head of the line. This continues until the coal is loaded out, which usually requires about six and one-half hours. 
When cleaned up the drive is reversed and the timber, which has arrived on the last trip, is run through on the conveyor to such points'on the block where it is required. When this is accomplished the power is shut off by means of a valve located at the top of the block heading. The hose is disconnected from the main feed pipe and the conveyor is moved up to the line row. This lateral move of the conveyor requires very little time, very seldom exceeding five minutes. A break row, consisting of two rows of props set 2 feet apart, is now placed along the lower side of the conveyor. These props are set on a cap piece, placed on a small pile of slack, and wedged at the top. Two break rows are all that is necessary to protect the block. In the meantime a portion of the crew are engaged in pulling out the extra break row. This is the most hazardous work on the block and is given personal attention by the block boss. Axes are used in this operation, and about 75 per cent of the props recovered are practically uninjured.

While the block crew are employed timbering the conveyor man and hoist boy make the necessary pipe connections and go along the conveyor with a pump jack and level it up. They also build a crib at the head end, which is placed so as to prevent the roof from breaking over into the block heading.

When the timber drawers have advanced such a distance from the machine that the noise of the exhaust will not annoy them, the machine begins cutting and is usually able to have one rail, or about 30 feet, cut before the shift is over.

With a 5-foot undercut the block throws 125 tons. Four cuts a week are on an average obtained from each block, which makes a daily average of 100 tons.

Although the results obtained from this system of mining were highly satisfactory, it was found there was still room for improvement, especially with regard to the original cost of the development and the dead work connected with the running of the block. It was with the idea of remedying these features and of improving on other less important conditions that the triple-conveyor system was designed and installed. After being in use for over a year in four of the mines where electricity is the power used the results obtained are even better than were anticipated.

In laying out a mine for this system the main entry and airway are driven up or down the pitch, and cross headings are driven off them at intervals of 400 feet at such an angle as will give a 2 per cent grade; 75 -foot barrier pillars are left on each side of the main entries. The cross heading is driven 20 feet wide and gobbed on the lower side. The air course, which afterward is used as the block face, is driven 20 feet wide, but no bottom is lifted; a 40-foot pillar is maintained. Block headings are run perpendicularly off the cross headings at 518-foot centers; they are driven 18 feet wide, with bottom lifted in the center 5 feet wide, and to such a depth as will give a clearance of 5 feet.

When the block is ready for operation a conveyor 350 feet long is placed in the block heading, and along the face of the air course on each side is placed a conveyor 250 feet long, with delivery ends directly over the main conveyor, one being 5 feet in advance of the other. Each conveyor is driven by a 20-horsepower 250-volt serieswound motor incased in a sheet-iron frame mounted on steel shoes, so as to be easily moved.

Airways are maintained on the blocks by driving two places slightly in advance of the block face, 6 and 4 feet wide, respectively, with a 10 -foot pillar between. The first place acts as. a stable for the machine and is driven by the machine. The airway is pick-mined, and one man manages to keep these other places going on the rear end of both blocks. By this arrangement no cribbing is necessary.

The blocks are worked to within 25 feet of the cross heading, when the conveyors are removed to another block. The remaining pillar is brought back along with the heading stumps.

The power is carried to the top of the block heading by a $2-0$ wire. Here are attached two insulated twin cables, one to furnish power to the machines, the other for the drives and hoist. 


\section{MINERAL RESOURCES OF JOHNSTOWN, PA., AND VICINITY.}

The cables are carried down the block heading, one on each side of the mair conveyor, being attached to it by means of malleable-iron brackets. At the junction of the conveyors connections are made with the drives, also with a cable that is attached to each of the face conveyors.

Stations are established 50 feet apart on the face-conveyor cables, to which connections are made with the short cable attached to the long-wall machines and electric drills. Switches are placed at the head end of the main conveyor, by which the power is controlled.

The method of handling the cars to the conveyor is simple. A side track is laid 300 feet long, of which the block heading is the center. Connection is made with the main track at the lower end, and a crossover switch is placed directly under the conveyor. At the upper end of the siding is placed an electric hoist. A trip of 14 cars is shoved into the empty track, and the rope is attached and the trip pulled up to the conveyor. Signal wires are hung between the conveyor and the hoist, and as each car is loaded the trip is pulled forward. When loaded the trip is dropped on the loaded siding, the rope disengaged and attached to the empties.

The crew operating a double block consists of 17 men-that is, block boss, machine runner and helper, driller, shooter, two conveyor men, hoist boy, five loaders, and four timber men.

Two long-wall machines are used, one for each side, although one machine can keep up the work in case of emergency.

As the machine men finish cutting one block they put the machine in position to start back on the cut and move over to the next block and begin cutting. They are followed by the shooter and loaders. The driller sets the line row and also has time to assist in loading.

When a block is cleaned up the timber men move up the conveyor, set the break rows, pull the timber, and make everything ready for the conveyor to start when the opposite block is loaded out.

The main conveyor, which is made up of 12 -foot sections, is disjointed about every third day, and one of the sections taken out and moved to the block heading next to be worked. The surplus length of cable is gathered on a reel located at the head end of the main conveyor.

The working of the face is similar to that of the single block with the exception that the machine men, loaders, etc., continue at their own special work during the whole shift, the dead work being taken care of by the four timber men, thus not hindering the steady flow of coal, which averages 150 tons per day.

For the purpose of keeping the machinery in as good a shape as possible, a skilled mechanic is attached to each mine. He assumes charge in case of an accident and makes necessary repairs,.although most of the breakdowns are easily taken care of by the block boss and machine man.

In the starting of a block is where the best results are obtained, as the roof requires little attention until about 100 feet have been extracted. It then begins to weigh heavy on the posts, and it is found necessary to carry three or four double break rows in anticipation of what is called the "big break." This usually occurs when the block is advanced from 100 to 150 feet, although in several instances a 500 -foot face has been carried up 200 feet before the overhanging strata broke. After the sand rock is down only two break rows are carried, and the roof keeps breaking behind the last row as the face is extended.

The men are paid day wages, and as they become accustomed to the work and machinery are advanced accordingly. The block boss, as an incentive to secure the best results, is paid a small bonus per ton besides his regular day rate.

The cost averages for the last two years show that block coal is Ioaded on the mine cars 35 per cent cheaper than the district mining rate, but this cost can be materially reduced when a few improvements now being worked out are brought to a state of perfection. Among these may be mentioned a more simple mechanical rig for spotting the mine cars and a scheme for reducing the amount of timber used. 
LITERATURE ON COAL MINING.

For the very latest information and statistical data, together with brief descriptions of the conditions of mines, improvements made therein, and the number and cause of accidents by years, the reader is referred to the annual volume entitled "Report of the Department of Mines, Pennsylvania." Most of the area included in the Johnstown quadrangle was in the sixth bituminous district of the State when this report was written. For information regarding coal-mining methods in general the reader is referred to the "Coal and metal miners' pocket book," ninth edition, 1904, pages 280 et seq.

CLAY AND SHALE.

MODE OF TREATMENT.

The clay materials of the Johnstown quadrangle are flint clays, plastic clays (including some fire clays), and shales.

On pages 14 to 28 of this bulletin a detailed description is given of the rocks in which the workable or potentially workable shale and clay beds are found, and to these preliminary descriptions the reader is referred for an explanation of the names which are applied to the beds containing the clays and which are employed in the following discussions. The treatment of the clays, like that of the coal, will be twofold, consisting of (1) a preliminary description of their general character and geologic position, followed (2) by a detailed description by districts, intended for the use of those who are more particularly interested in the subject. The detailed descriptions will be accompanied by analyses and sections. The distribution of the clay beds which are regarded as of economic importance is shown on Plate I by means of purple lines.

\section{GENERAL DESCRIPTION.}

FIINT CLAYS.

Flint clays occur at three or more horizons in the Johnstown area. The highest is in the Conemaugh formation and ranges in position from 50 to nearly 100 feet above the Upper Freeport coal. It usually occurs very close to the Mahoning coal in the hills immediately about Johnstown, and its distance above the Upper Freeport coal is therefore nearer 50 to 75 feet than 100 feet. A clay in a similar position with respect to the top of the Allegheny formation was also observed in the hills north of South Fork. It appeared to be of the ordinary plastic variety. In the Blacklick Creek district, near Wehrum, a flint clay has been observed at many places in a similar position with reference to the Mahoning sandstone member. This flint clay, which

$69516^{\circ}-$ Bull. $447-11-8$ 
in many places attains a thickness of 7 feet, is probably to be correlated with the flint clay occurring near Johnstown.

In the Allegheny formation a flint clay was observed near the northwest edge of the quadrangle, in the valley of Mardis Run. It occurs 25 feet below the Upper Freeport coal and probably corresponds with the Bolivar flint clay of the area to the west.

The most important flint clay in the entire quadrangle is that occurring at the Mercer horizon in the hills about South Fork, where it is associated with plastic clay. In the mine of J. H. Wickes it is $4 \frac{1}{2}$ feet thick. The flinty character is persistent between South Fork and Mineral Point, but elsewhere throughout the quadrangle the Mercer member is usually characterized by a band of shale and plastic clay.

PLASTIC CLAYS.

Plastic clays have been observed at many horizons in the Johnstown quadrangle. At only a few places, however, are their position with reference to transportation facilities and their thickness such as to make them of great economic importance. A few plastic-clay beds have been observed in the Conemaugh formation. Many of the coals in the Allegheny formation are underlain by plastic clays. The clay below the Upper Freeport is of workable thickness at some places. Below the "cement rock" associated with the Upper Kittanning (Cement) coal a deposit of clay was noted at some places around Johnstown. The most important plastic clay in the Allegheny formation is that below the Lower Kittanning (Miller or B) coal bed, and it is extensively mined around Johnstown and South Fork in connection with that coal. It is mixed with the flint clay from South Fork and Dean station to make all grades of fire brick and refractory material in general. This clay varies in thickness from less than 3 feet to 12 feet, of which from $2 \frac{1}{2}$ to 5 feet is worked in the most important clay mines near Johnstown. At Seward 12 feet of clay is reported below the Lower Kittanning coal, but of this thickness only 6 feet is mined and used in the manufacture of buff or lightcolored brick.

In the northern part of the quadrangle, along Blacklick Creek and at Conemaugh Furnace, the clay below the Lower Kittanning coal is of workable thickness, and there is no reason why its quality should not compare with that of the plastic clay near Johnstown and South Fork. So far as known, however, it has never been mined in connection with the coal in either of these districts.

The lowest plastic clay in the region occurs at the Mercer horizon. This clay is associated with and occurs immediately above the flint clay at the same horizon near South Fork. Plastic clay of Mercer age is also found on Stony Creek in the hills north of the mouth of Paint Creek and farther to the south. It is also present in the hills 
north of Sheridan and is worked at a quarry in this locality. The corresponding clays have been prospected but are not worked at present on the west slope of Laurel Ridge, a few miles southeast of Conemaugh Furnace.

SHALES.

In the Johnstown quadrangle valuable shale beds are scattered through the Conemaugh and Allegheny formations, and in the Pottsville formation the Mercer member is nearly everywhere characterized by the presence of a shale bed of varying thickness. Near Johnstown valuable shale beds occur in the lower 300 feet of the Conemaugh formation and are worked near the city. The higher beds of the Conemaugh are exposed in the railroad cuts west of Wilmore, and the numerous shale beds there included (see section, p. 16) insure the presence of much good brickmaking material admirably situated with respect to transportation. At the Bruce H. Campbell quarry, north of Sheridan, a clay that is associated with rounded bowlders and is presumably of Pleistocene age is worked $(\mathrm{Pl}$. V, B). Residual clays are so widely distributed in this quadrangle as hardly to merit detailed mention.

\section{DESCRIPTION BY DISTRICTS}

JOHNSTOWN DISTRICT.

FLINT CLAYS.

Flint clay occurs persistently at but one horizon in the Johnstown district. This horizon is at or just above the Mahoning sandstone member and in the hills surrounding the city it is 50 to 70 feet above the Upper Freeport (Coke Yard) coal. Though fairly well distributed in favorable locations for easy exploitation, this clay is, so far as known, worked only by the Johnstown Pressed Brick Company at its plant on a hill east of the city. A section of the rocks in the hill will show the position of this clay and its relation to the underlying coal, which is at the top of the Allegheny formation.

Section of lower part of Conemaugh formation in hill east of Johnstown.

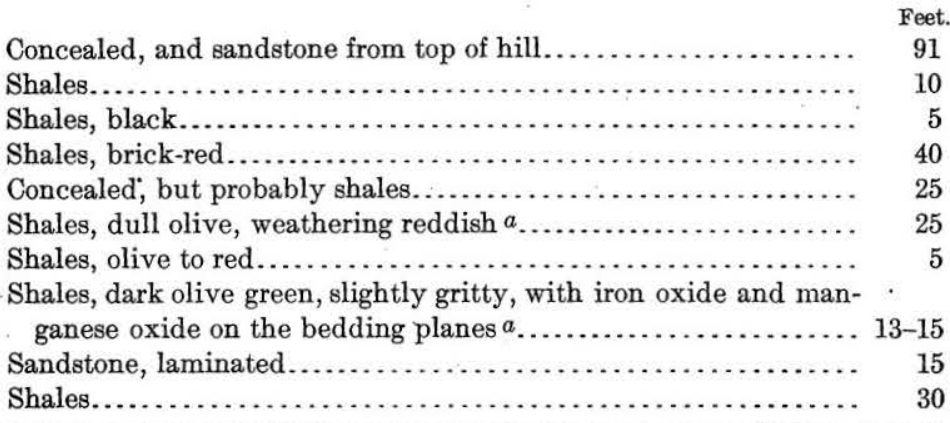

$a$ Beds worked for brick material. 


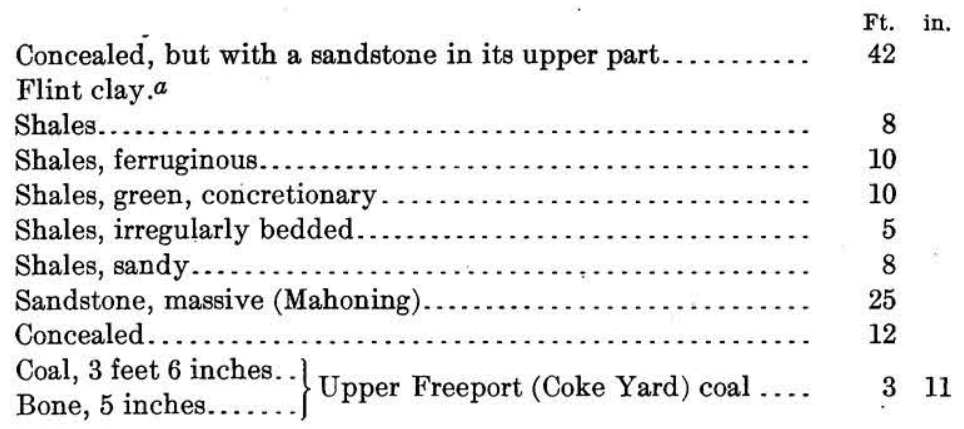

Fragments of flint clay have been seen in the following localities near Johnstown: On the road ascending Shingle Run, in Dale Borough, east of Johnstown, more than 2 feet of flint clay associated with shale was measured 60 feet above the Mahoning sandstone member. An old prospect hole on this flint clay was seen on the road leading to Grandview Cemetery, in which the clay was about 65 feet above the Upper Freeport (Coke Yard) coal; it was of a light-straw color and appeared to be of good quality. On the Ferndale-Johnstown road, a short distance north of the Eighth Ward mine of the Citizens Coal Company, an abundance of flinty clay débris occurs above the road near the top of the massive Mahoning sandstone. In the hill above the Baltimore and Ohio Railroad tunnel east of Island Park, on the new county road, some flint clay was observed about 40 feet above the Upper Freeport coal and near the top of the Mahoning sandstone. Northwest of Johnstown, in the hills bordering Laurel Run and its branches on the east, a short distance east of the old coke yard from which the Upper Freeport gets its local name, this flint clay is exposed, indicating a probable continuity of the bed as far west as the valley of Laurel Run. Here again the flint clay is about 50 feet above the Upper Freeport coal. Northwest of Johnstown, on the road ascending Pleasant Hill from the valley of Conemaugh River, a flint clay occurs about 110 feet above the Upper Freeport coal and 10 feet below a smaller bed of coal. This smaller bed of coal may possibly be higher stratigraphically than the seam 70 feet above the Upper Freeport at the Baltimore and Ohio Railroad tunnel near Island Park; if so, the flint clay of Pleasant Hill is higher than that previously described, and there are two flint-clay horizons in the 100 feet at the base of the Conemaugh formation. At the southern edge of the quadrangle, in Somerset County, in the hills bordering Stony Creek, this same flint clay has been observed.

Should the clay after careful prospecting prove to be present in sufficient quantity and of such quality as to justify its exploitation at the above-named localities, it could be marketed, as most of the 
occurrences which have been noted are conveniently situated with respect to transportation. Deposits of this clay too far removed from market and transportation to have commercial value have also been observed on the headwaters of Mill Creek and Dalton Run.

It should be added that the occurrences noted above are largely roadside outcrops at which it is impossible to determine the exact thickness and nature of the clays. Only careful prospecting can determine these points, but the fact that one of the flint clays is being exploited at one locality is significant.

PLASTIC CLAY.

The flint clay above the Mahoning sandstone assumes a plastic phase at places in the Johnstown district. Most of the valuable plastic clay in this region, however, occurs in the Allegheny formation ("Lower Productive Coal Measures"). At a few places a clay bed of workable thickness occurs below the Upper Freeport coal, in connection with which it might be mined. At the Cyrus Shepard mine, leased by L. J. Mitchell, east of Franklin and near the mouth of Clapboard Run, 2 feet $4 \frac{1}{2}$ inches of clay were measured by Mr. Martin, but the clay is known not to be persistent, as but a short distance away the section obtained shows an entirely different aspect.

A clay bed underlies the Johnstown limestone member-that is, the limestone occurring near or just below the base of the Upper Kittanning (Cement) coal. This clay has been worked, but it is not now exploited. It is referred to in the report on this district by F. Platt and W. G. Platt ${ }^{a}$ as having been developed by Mr. Haws, of Johnstown. The clay was analyzed by T. T. Morrell, ${ }^{a}$ with the following results:

Analysis of clay occurring below the Johnstown limestone member.

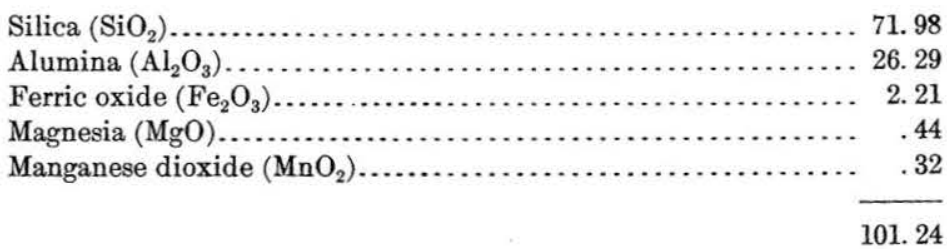

The most valuable clay in the Allegheny formation is that underlying the Lower Kittanning (Miller) coal. Many of the mines working this coal around Johnstown produce also considerable amounts of the clay. The clay bed in this district ranges from less than 3 to about 6 feet in thickness, but locally it may be even thicker than this. It usually underlies the lower bench of the Lower Kittanning coal, from which it is separated by a few inches of shale; or, in the absence 


\section{MINERAL RESOURCES OF JOHNSTOWN, PA., AND VICINITY.}

of the lower bench, it occurs below the main coal itself, separated from it by about 3 to 4 inches of bone or shale. It is a light-drab clay, not very hard, of irregular fracture, greasy to the touch, and șlakes on exposure to the weather. Its composition is indicated by the following analyses:

Analyses of clay underlying the Miller seam.

\begin{tabular}{|c|c|c|c|c|}
\hline . & 1. & 2. & 3. & 4. \\
\hline 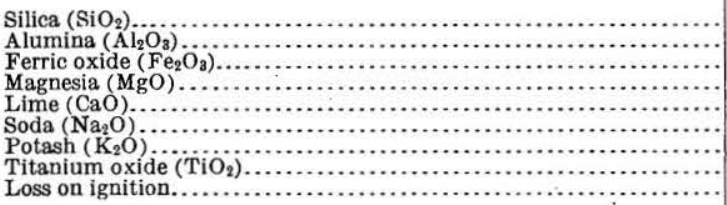 & $\begin{array}{r}65.90 \\
20.30 \\
a 1.60 \\
.66 \\
.09 \\
.34 \\
2.98 \\
1.20 \\
6.50\end{array}$ & $\begin{array}{r}66.40 \\
19.80 \\
a 1.68 \\
.61 \\
.10 \\
.30 \\
3.24 \\
1.00 \\
6.40\end{array}$ & $\begin{array}{r}53.10 \\
27.80 \\
a 3.08 \\
.60 \\
.22 \\
.48 \\
3.58 \\
1.20 \\
10.20\end{array}$ & \begin{tabular}{r}
68.82 \\
20.85 \\
2.79 \\
.23 \\
.82 \\
$\ldots \ldots \ldots .$. \\
\hdashline $\mathrm{MnO}_{2} .60$ \\
\end{tabular} \\
\hline & 99.57 & 99.53 & 100. 26 & 100.00 \\
\hline
\end{tabular}

a Total iron calculated as $\mathrm{Fe}_{2} \mathrm{O}_{3}$.

1. Citizens' Coal Company's Green Hill mine, Johnstown; E. C. Sullivan, analyst.

2. A. J. Haws \& Sons (Limited) mine, near the stone bridge, Johnstown; E. C. Sullivan, analyst.

3. Seward Coal Company's mine, Seward, Westmoreland County, Pa,; E. C. Sullivan, analyst.

4. Clay underlying the Lower Kittanning (Miller) seam at Johnstown; T. T. Morrell, analyst. Second Geol. Survey Pennsylvania, Rept. H2, p. 148.

This clay is worked about Johnstown by W. J. Williams at Kernville. Below the coal at the Kernville mine there is a shale layer of varying thickness, about 2 to 6 inches in places, below which is from 3 to 5 feet of plastic clay. This clay is mined and used at one of the local brickyards. At the Green Hill mine of the Citizens' Coal Company the average thickness of the underlying clay is 5 feet. This also is shipped to a local brick plant. This clay is mined by A. J. Haws \& Sons (Limited), both at their shaft near the famous stone bridge in Johnstown and to the west at Coopersdale. In the shaft workings an average of nearly 3 feet is worked. At Coopersdale it averages $3 \frac{1}{2}$ feet in thickness but in places runs as thick as 5 feet. It was observed in the mine that when the clay attained its maximum thickness the coal appeared in a single bench, with its lower 4 or 5 inches bony. At both the Haws mines the Lower Kittanning coal is mined with the clay, and is used as the fuel to burn the brick at the brick plants situated at the mine mouths. The clay is also mined by Robertson \& Griffith on St. Clair Run in connection with the overlying coal.

Nearly all the product of the Johnstown clay mines is used at local brick plants, where it is mixed with flint clay from the Mercer horizon, shipped chiefly from South Fork and Dean station. When thus mixed with the flint clay it forms a suitable bond in a product that is used in the manufacture of high-grade refractory products and bricks for blast-furnace and open-hearth work, and in making sleeves, nozzles, tuyeres, and other articles exposed to high temperatures. In the most refractory products nothing but flint clay is used. 
The lowest plastic clay in the Johnstown quadrangle is associated with the Mercer coal and is not exposed immediately about the city. In the hills lying east of Stony Creek, south of Kring, on the Baltimore and Ohio Railroad, this horizon has been prospected and some clay and shale have been found, but they have never been worked. At one exposure of the Mercer south of the quadrangle, on the west flank of the Ebensburg anticlinal axis, more than 11 feet of clays and shales were measured in one exposure. Flint clay was not observed in connection with the Mercer at any of the old prospect pits.

North of Sheridan, at the quarry of Bruce H. Campbell, the following section was measured, showing 6 feet and possibly more of - clay below the Mercer coal:

Section of Mercer shale member at Bruce H. Campbell quarry, north of Sheridan.

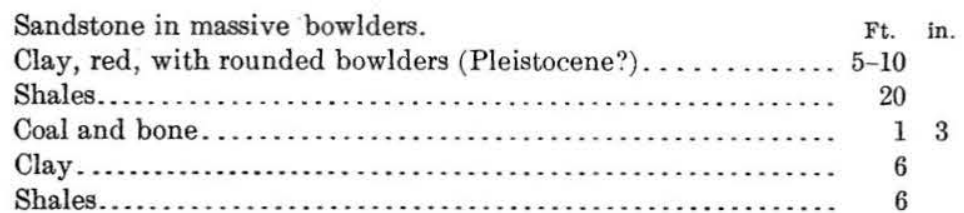

That the underlying clay and shales are much thicker than is indicated by the above section has been proved by sinking three test holes. Both red and buff building bricks are made from the clays and shale quarried here.

SHALES.

It has been remarked that the most important shale horizons about Johnstown are confined to the lower 300 feet of the Conemaugh formation. The section given on pages 115-116 shows the character of the lower 400 feet of beds in this group of rocks in a hill east of the city. From about 50 feet above the top of the Upper Freeport (Coke Yard) coal to the top of the hill numerous promising beds of shale are exposed. Most of the shale group lying between 165 and 210 feet above the Upper Freeport coal is being worked by the Johnstown Pressed Brick Company into a good building brick of both the buff and red varieties. The fuel used in burning the brick is obtained from the Upper Freeport coal, which the company works in the same hill. The shales are ground through a 12-mesh sieve, or to a size to make them "ball." The material is then hoisted by a bucket-belt conveyor to the sieve, thence sent through a hopper to the pans, after which it is pressed into brick, the dry-press process being used.

The composition of the shales employed is indicated below. The shales were first air dried and then subjected to the usual fusion, with subsequent analyses. 
Ultimate and rational analyses of shales from hill east of Johnstown.

\begin{tabular}{|c|c|c|}
\hline & 1. & 2. \\
\hline 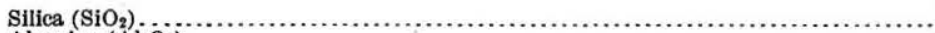 & 51.32 & 64.29 \\
\hline 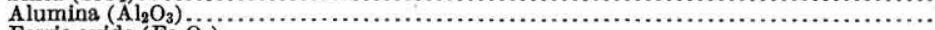 & 24.39 & 17.95 \\
\hline 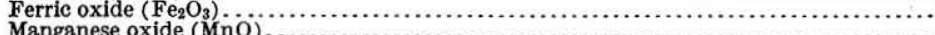 & 6.94 & 5.74 \\
\hline 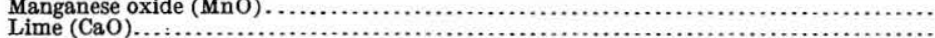 & .14 & Trace. \\
\hline 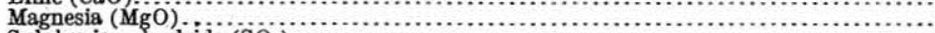 & 1.73 & 1.30 \\
\hline 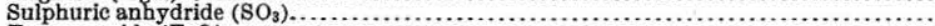 & Trace. & Trace. \\
\hline 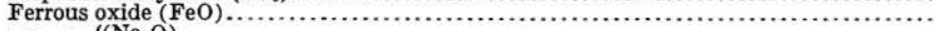 & 1.43 & 1. 64 \\
\hline 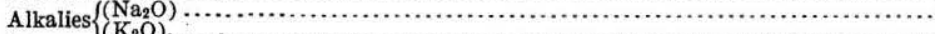 & .23 & .35 \\
\hline 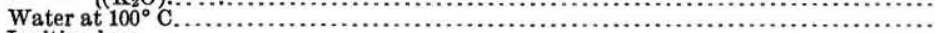 & $\begin{array}{r}1.09 \\
.92\end{array}$ & $\begin{array}{r}1.80 \\
.95\end{array}$ \\
\hline 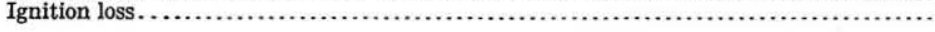 & 11.32 & 5. 44 \\
\hline & 100.21 & 99.92 \\
\hline \multirow{4}{*}{ 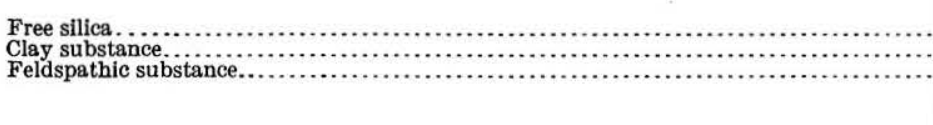 } & 10.09 & 28.54 \\
\hline & 81.51 & 57.85 \\
\hline & 8. 40 & 13. 61 \\
\hline & 100.00 & 100.00 \\
\hline
\end{tabular}

1. Sample collected from upper shale bed: see section (p. 115). Analysis made at the structural-materials laboratory of the United States Geological Survey at St. Louis. A. J. Phillips, analyst.

2. Sample collected from lower shale bed; see section (p. 115). Analysis made at the structural-materials laboratory of the United States Geological Survey at St. Louis. P. H. Bates, analyst.

In Prospect Hill, north of Johnstown, the Cambria Steel Company has quarried shale lying about 80 to 100 feet above the Upper Freeport coal and utilized it in connection with the overlying surface clay in the manufacture of red building brick of good quality. The brick plant of the company is located at Cambria.

The geologic structure immediately near Johnstown is such that the beds lie fairly flat and the lower few hundred feet of the Conemaugh formation is exposed. Sections obtained in the hills around the city and along the Pennsylvania Railroad to the west indicate that the lower part of this formation is of prevailingly shaly character, comparable with that seen in the hill to the east. It is therefore probable that a great deal of brickmaking material exists in these hills which has never been tested. Though all this shale may not be of the grade of that worked by the Johnstown Pressed Brick Company, some of it probably is, and much of it may be suitable for paving brick, sewer pipe, fireproofing of various sorts, and other rough material. All the shale in the hills about the city and to the west is fairly accessible to transportation, and cheap fuel is assured by the presence of valuable coal beds 300 feet or more below.

The lowest promising shale horizon in this district is associated with the Mercer coal. The prospect pits on the Baltimore and Ohio Railroad south of Kring show the presence of dark shales at this horizon. At points north of Sheridan the Mercer shale is thick and is worked in connection with the overlying Pleistocene clays at the quarry of Bruce H. Campbell. (See Pl. V, B, p. 28.) The section on page 119 shows 20 feet of shales overlying the coal, and the thickness of brickmaking material at the base of the section is known from test holes put down by the company to be much greater. The shales in the 20-foot bed given near the top of the section are dark brown 
and drab in color, somewhat sandy, and concretionary. This shale is mixed with the overlying clay, and the mixture is used in making a buff or red building brick, the color depending on the proportions of shale and clay used. The beds worked at this quarry rise abruptly toward the west at a rate that soon carries the Mercer horizon with its shales over the tops of the hills.

Mr. Martin collected a sample of the shale from this quarry, taking it from the entire width of the exposure and then mixing it with the overlying clay in the proportion of 2 parts of shale to 1 of clay. The sample was analyzed by P.H. Bates, of the structural-materials laboratory of the Survey at St. Louis, with the following results:

Ultimate and rational analyses of shale and clay from Mercer shale member, B. H. Campbell quarry, north of Sheridan.

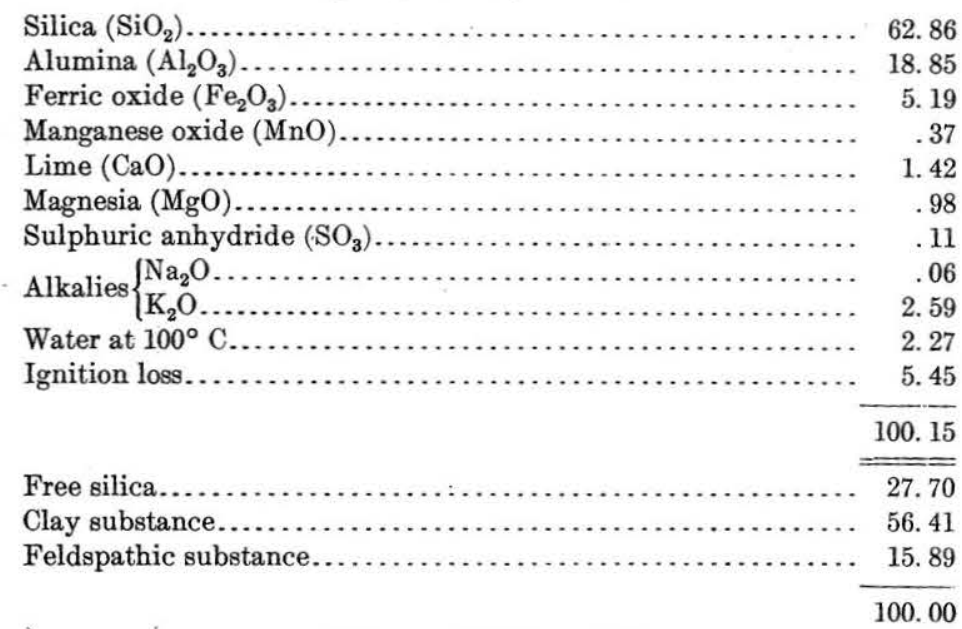

SOUTH FORK DISTRICT.

FLINT CLAY.

A band of clay that occurs in the Pottsville formation in the South Fork district has been worked at points south of the Pennsylvania Railroad from South Fork westward beyond Mineral Point and also at a few places north of the railroad. In this district this clay is characterized by a persistent flinty streak. This clay is present in the hills along Conemaugh River in an area extending west to about 1 mile east of Conemaugh station. The outcrop is continuous except where the local dips and change in direction of the river carry it below drainage. The flinty clay may not be present at all points between Mineral Point and Conemaugh. For example, the clay observed at this horizon in the tunnel of the old Portage Railroad is not particularly flinty in character. From Mineral Point to South Fork, however, the flinty character is persistent.

This flint clay is now worked by the Garfield Fire Clay Company near the viaduct and by J. H. Wickes and the South Fork Fire Brick 
Company west of South Fork. The following section was measured at Mr. Wickes's mine:

Section of fire clay at J. H. Wickes's mine, South Fork.

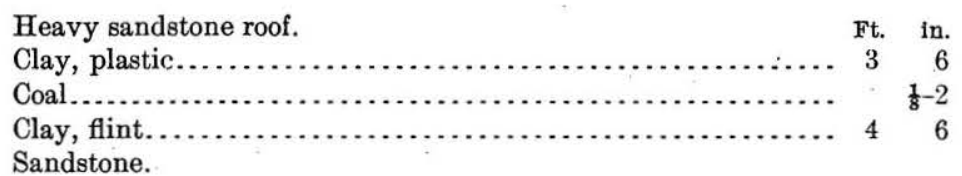

This clay was also worked by the Page-Reigard Mining Company near Mineral Point and at South Fork, but in July, 1904, the mine at South Fork was shut down. It is reported that the plastic clay is persistent but that the thickness of the flint clay is variable, dwindling to 14 inches in a northeast-southwest zone. A specimen of the clay was collected in October, 1906, and analyzed by A. J. Phillips at the structural-materials laboratory of the United States Geological Survey at St. Louis. This analysis (No. 1 in the table below) may be compared with an analysis of what is believed to be clay from the Mercer, taken from the central band of the bed worked years ago near the viaduct. This latter clay was not definitely fixed in its stratigraphic relations by the Platts. ${ }^{a}$ It was regarded by them as clearly underlying all the workable coals and as being connected with the "Conglomerate Rock," as the Pottsville was sometimes called, anil as being the equivalent of the fire clay of Sandy Ridge, which is known to be in the Mercer member. The third analysis in the table represents clay from the middle layer in the Sandy Ridge bed.

Ultimate and rational analyses of Mercer clays.

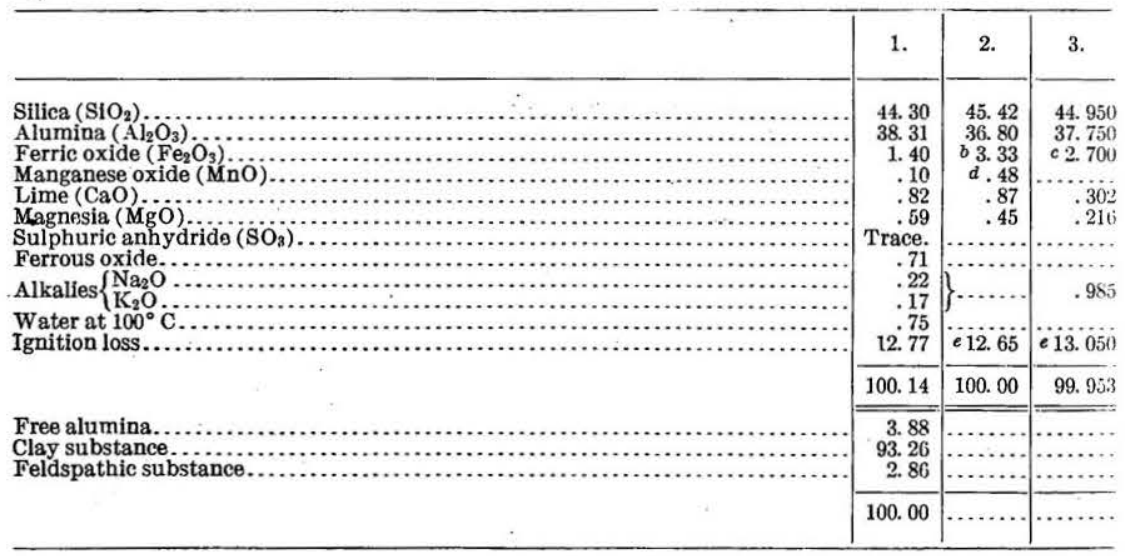

a Second Geol. Survey Pennsylvania, Rept. H2, 1875, p. 146.

"All iron reported as peroxide of iron.

c Reported "oxide of iron."

d Calculated as $\mathrm{MnO}_{2}$.

e Reported as water and organic matter.

1. Flint clay from Mercer horizon, A. J. Wickes's mine, South Fork; A. J. Phillips, analyst.

Flint clay from Mercer horizon, near the viaduct; T. T. Morrell, analyst, Second Geol. Survey Pennsylvania, Rept $\mathrm{H}_{2}, 1875$, p. 147 .

3. Fire clay of Sandy Ridge; A. S. McCreath, analyst, Second Geol. Survey Pennsylvania, Rept. II, 1874, p. 119. 
There is a striking similarity among these analyses.

At South Fork the clay is smooth, hard, compact, light to dark gray in color, breaks with a conchoidal fracture, and burns to a straw-yellow color. The analysis indicates a high-grade material, with perhaps a little too much iron.

The clay mined at South Fork is in part shipped to Johnstown and in part mixed with plastic clay from the Lower Kittanning seam and used at the local brick plant. Some of the products of this flint clay have been tested for refractoriness at the plant of the Cambria Steel Company at Johnstown and have proved highly satisfactory.

PLASTIC Clay.

About South Fork a plastic clay of doubtful value has been observed at a few places near the top of the Mahoning sandstone; its position corresponds with that of the band of flint clay in the Johnstown district. The clay below the Upper Freeport (Lemon) coal bed is fairly thick in this region, but it is not worked at present. At O. M. Stineman's mine No. 3 this coal is underlain by 2 feet 3 inches of clay, which may be worked at some future time in connection with the coal. This clay is not comparable in thickness with that which directly underlies the Lower Kittanning (Miller) coal seam, and which about South Fork, as near Johnstown, is the most important plastic clay in the Allegheny formation. The plastic clay associated with the Lower Kittanning coal seam is usually workable, at some places having a thickness of 6 to 8 feet and averaging about 3 to 4 feet of workable clay of good grade. A brief note on the character of this clay will be found in the description of its occurrence in the Johnstown district (p. 117), where analyses also are given. There is every reason to suppose that in this district it is of the same quality as about Johnstown. Most of the South Fork clay is mined in connection with the coal and is used almost entirely at the local brick plant.

SHALE.

So far as known the shales in the South Fork district have not been utilized. In the two large cuts west of the town of Wilmore, on the main line of the Pennsylvania Railroad, shale beds are exposed that vary in position from 400 to 675 feet above the Upper Freeport coal. In the surrounding hills many promising shales are found conveniently situated with respect to transportation. Their appearance indicates that they may be adapted to the manufacture of paving brick and other materials that require only an inferior grade of clay or shale; to determine their fitness for any purpose, however, practical tests must be made. In a recent cut opposite Ehrenfeld, along the new county road, a bed of shale 50 to 60 feet thick, lying 60 feet above the Upper Freeport coal, also appears to be promising. 
BLACKLICK CREEK DISTRICT.

The South Branch of Blacklick Creek flows along the northern edge of the Johnstown quadrangle. It is joined by the north branch $\mathrm{a}^{\text {t }}$ short distance west of Vintondale, and the main stream flows westward beyond the limits of the area. Deposits of flint and plastic clay are found in the adjacent hills along the creek, and although many of these are conveniently situated with respect to lines of transportation the demand has not yet been sufficient to justify their exploitation.

FLINT CLAY.

The flint clay in the Blacklick Creek district occurs at two horizons. The higher is found in the lower part of the Conemugh formation, above what is thought to be the equivalent of the Mahoning sandstone member and a few feet below a small coal bed, possibly the Mahoning coal. This flint clay has been observed in many places north, west, and south of Wehrum, but the rise of the beds toward the east causes a gradual increase in its distance from the valley and from transportation facilities and finally its complete absence from the hills. West of Wehrum, however, both north and south of Blacklick Creek, it occurs at many points, having in places the unusual thickness of 7 to 8 feet. It is a typical flint clay in appearance, though its content of iron oxide is apparently very high. A sample collected from a roadside exposure west of Dilltown gave the following analysis:

Partial analysis of flint clay from a natural exposure west of Dilltown.

[E. C. Sullivan, analyst.]

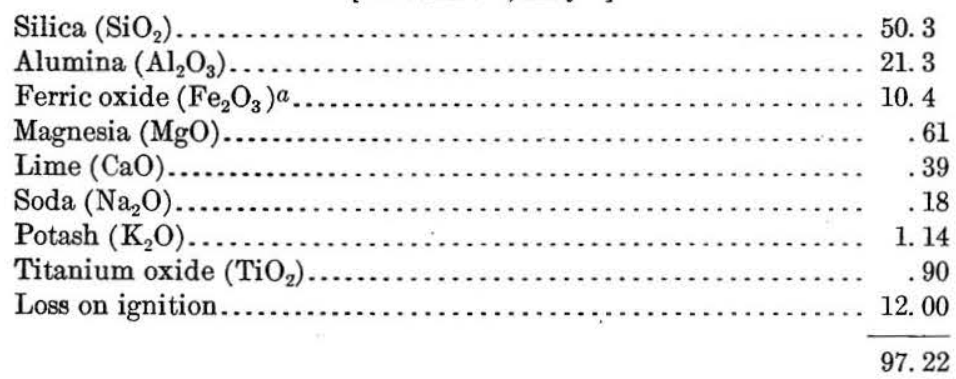

The percentage of fluxing materials, principally iron oxide, indicated in this analysis, is so high as to prohibit its practical use. A lower flint clay, lying a few feet below what may prove to be the Upper Freeport coal, was seen at a few places in the valley of Mardis Run, near the northwestern edge of the quadrangle. This clay may correspond to the Bolivar clay of the region to the southwest. Two feet of clay was seen at one point on the outcrop and the bed may possibly be thicker. This clay is rather remote from transportation. 
PLASTIC CLAY.

The coal that is being extensively worked in the valley of Blacklick Creek is regarded as the equivalent of the Lower Kittanning (Miller or B) seam of the Johnstown and South Fork districts. In the Blacklick Creek district, as well as along Conemaugh River, this coal is underlain by a promising clay bed. This clay is not exploited at present, and no certain measurement of its thickness was obtained. At many of the mines 2 feet or more of promising clay was seen, comparable, in appearance at least, with that in the Johnstown district.

MISCELLANEOUS LOCALITIES.

Along the western flank of Laurel Ridge, near the line of the Pennsylvania Railroad, the Lower Kittanning (Miller) coal has been opened at a few places and the clay underlying it found to be of workable thickness. At the coal mine of the Johnstown Coal Company more than 2 feet of clay was seen; and near Seward, beyond the western limits of the quadrangle, 12 feet of clay occurs in the same position, 6 feet of which is worked by the Seward Brick Company. $^{a}$

About 2 miles southeast of Conemaugh Furnace, on the main line of the Pennsylvania Railroad and south of it, the Conemaugh Stone Company has done considerable quarrying in the Pottsville and has exposed the Mercer shale member. The following section was measured but does not show the complete thickness of the clay:

Section showing Mercer shale member and accompanying clays at quarry of Conemaugh Stone Company.

Shale, dark, with 2 inches of bone near base............ 3

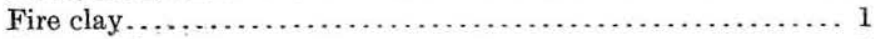

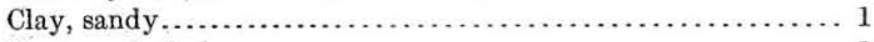

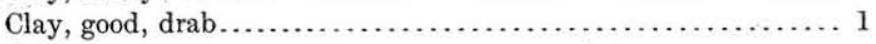

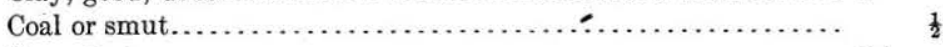

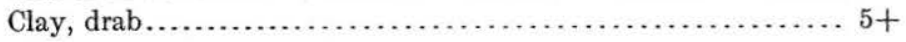

PRODUCTION.

The firms named below are engaged in the brick and clay industry in this area. In addition coal companies mining the Lower Kittanning coal about Johnstown and South Fork may produce small quantities of the underlying clay for use in the local brick plants.

Clay miners:

Page-Reigard Mining Company, flint clay, Mineral Point.

W. J. Williams, plastic clay, Kernville.

Citizens' Coal Company, plastic clay, Green Hill mine, Johnstown.

Robertson \& Griffith, plastic clay, St. Clair Run, Morrellville.

a For an analysis of the clay underlying the coal mined at Seward, see p. 118. 
Manufacturers of fire brick:

A. J. Haws \& Sons (Limited), Johnstown and Coopersdale.

Hiram Swank Sons, Johnstown.

South Fork Fire Brick Company, South Fork.

Manufacturers of building brick:

Cambria Steel Company, Johnstown.

Bruce H. Campbell Brick Company, Sheridan.

Johnstown Pressed Brick Company, Johnstown.

\section{BRICK INDUSTRY.}

The brick industry in the vicinity of Johnstown has grown to considerable magnitude. Some of the flint clay used in the manufacture of the fire brick and other more refractory products is shipped from other parts of the State, but except for this most of the raw material used is of local occurrence.

\section{LIMESTONE AND CEMENT MATERIALS.}

EXTENT.

In the Conemaugh formation of western Pennsylvania numerous limestone members have been found and traced with certainty over broad areas. These have been proved to be so constant in their position in the geologic column that they have been named and have served as guides in unraveling the stratigraphy. Some of these are the Pittsburg, Clarksburg, Elk Lick, Ames or "Crinoidal," and Upper and Lower Cambridge limestone members of the Allegheny Valley, and the Johnstown iron-ore bed, which is in places nothing more than a ferruginous limestone at an inconsiderable distance from the outcrop. Some of these limestones undoubtedly occur in the Johnstown quadrangle. Actual correlation has not been made, however, partly because the limestones in the quadrangle are regarded as lenticular and partly because they are so numerous that they can not be correlated certainly with the persistent and characteristic limestones of the Allegheny Valley.

The limestones of the Conemaugh are of no importance whatever commercially and have never been used except for fertilizing purposes on a very small scale. The limestones in the Allegheny are of greater importance than those in the Conemaugh. They are three in number-the Upper Freeport limestone member, the Lower Freeport limestone member, and the Johnstown limestone member.

\section{UPPER FREEPORT LIMESTONE MEMBER.}

The Upper Freeport limestone member appears in the section only near South Fork and Ehrenfeld. A short distance east of Ehrenfeld it is exposed in some recent excavations along the main line of the Pennsylvania Railroad. It is a gray limestone from $1 \frac{1}{2}$ to 3 feet in 
thickness and at Ehrenfeld it is very irregularly bedded. It lies a short distance below the Upper Freeport coal, being separated from it by about 2 feet of clay containing limestone nodules in its lower foot: So far as known, this particular limestone has never been used in this area.

\section{LOWER FREEPORT LIMESTONE MEMBER.}

The Lower Freeport limestone member occurs either directly below or within a foot of the base of the Lower Freeport coal, the slight interval as a rule being occupied by black shale. It ranges from $1 \frac{1}{2}$ to nearly 4 feet in thickness. The best exposures in the quadrangle occur along Stony Creek (Pl. IV, $A$, p. 24) and the Baltimore and Ohio Railroad between Moxhom and the mine of the Valley Coal and Stone Company. This limestone has never been used in any way.

\section{JOHNSTOWN LIMESTONE MEMBER.}

The limestone occurring below the Upper Kittanning or Cement coal is known locally as the Johnstown cement bed. It is best developed along Stony Creek and may be seen to advantage on the Baltimore and Ohio Railroad north of Kring, where it is 6 feet thick and is separated from the coal by 8 to 12 inches of shale. Along the spur track leading from the north end of the Baltimore and Ohio tunnel to the mine of the Valley Coal and Stone Company it is also conspicuous but slightly thinner. (See Pl. VII, A, p. 48.) The sections measured by hand level (see pp. 44 and 47) indicate the relations of this limestone and show its thickness where measured in this part of the quadrangle. The bed is nearly $8 \frac{1}{2}$ feet thick near Conemaugh depot and nearly 5 feet in the section along the Pennsylvania Railroad to the west, approaching Johnstown depot. To the east, on Conemaugh River, it is exposed just at the northwest apex of the first big meander. It must be thick in all the intermediate territory. Its outcrop along Stony Creek near the Rolling Mill mine of the Cambria Steel Company is also conspicuous. Northwest of Johnstown, near the old Cambria furnace and at the east base of Laurel Hill, it outcrops and shows just above the waters of Laurel Run. Here it is a bluish limestone with a few streaks of calcite. It is present but not very thick near South Fork, and is also reported near Scalp Level, just across the Somerset County border.

In the reports of the Second Geological Survey of Pennsylvania ${ }^{a}$ this bed is called the "Ferriferous limestone," but its identity with the limestone of the same name of the Allegheny Valley was left open for more complete and harmonious evidence than was available when the report on Cambria and Somerset counties was written. 
The limestone at this horizon was worked at one time. In the report of the Second Geological Survey, Platt mentions the Haws Cement Works as utilizing this rock occurring on Stony Creek not far from the Rolling Mill mine. He describes it as being bluish gray in color, hard, and brittle, showing small crystals of iron pyrites, and containing considerable clay. The deposit worked was dolomitic in character. The sample collected near Kring for analysis is also dolomitic in character. (See analysis 1.) Such high magnesian limestones have been used in the manufacture of natural cements near Utica, La Salle County, Ill., in the Louisville district of Indiana and Kentucky, and in the Rosendale district, Ulster County, N. Y. The magnesia, in natural cements at least, may be regarded as equivalent to lime so far as the hydraulic properties of the product are concerned. The presence of magnesium carbonate in a natural cement rock is merely incidental, while the silica, alumina, and iron oxide are essential. For comparison average analyses of limestones from the different districts mentioned above are given below, together with that of the limestone near Johnstown:

Analyses of limestones suitable for making cement.

\begin{tabular}{|c|c|c|c|c|}
\hline & 1. & 2. & 3. & 4. \\
\hline 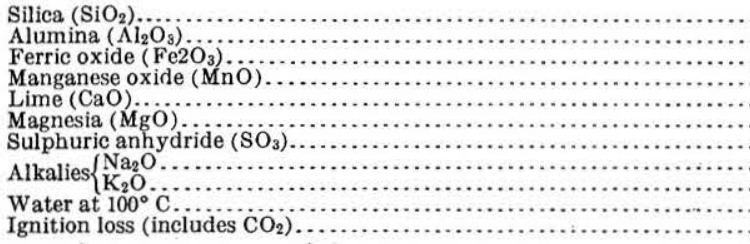 & $\begin{array}{r}14.44 \\
7.82 \\
1.54 \\
.20 \\
25.05 \\
13.29 \\
.15 \\
.28 \\
.86 \\
.28 \\
36.48\end{array}$ & $\begin{array}{r}20.92 \\
2.35 \\
26.32 \\
12.10 \\
a 1.81 \\
c .18 \\
36.73\end{array}$ & \begin{tabular}{r}
13.34 \\
3.46 \\
1.90 \\
\hdashline 31.49 \\
11.19 \\
$\cdots \ldots \ldots . .$.
\end{tabular} & $\begin{array}{r}18.04 \\
6.18 \\
2.63 \\
25.23 \\
12.47 \\
\text { b. } .78 \\
\text { n. d. } \\
\text { n.d. } \\
\text { d. } 1.20 \\
e 33.31\end{array}$ \\
\hline
\end{tabular}

1. Sample collected on Baltimore and Ohio Railroad north of Kring. Analysis made at structuralmaterials testing laboratory, United States Geological Survey, St. Louis, Mo. A. J. Phillips, analyst.

2. Average of five analyses of natural cement rocks, Utica, Ill. Eckel, E. C., Bull. U. S. Geol. Survey No. 243,1905 , p. 340 .

3. Average of six analyses of natural cement rocks, Louisville district, Indiana-Kentucky. Eckel, E. C., Bull. U. S. Geol. Survey No. 243,1905 , p. 341.

4. A verage of six analyses of natural cement rocks, Rosendale district, New York. Eckel, E. C., Bull. U. S. Geol. Survey No. 243,1905, p. 346 .

The close agreement among the foregoing analyses strongly suggests that the Johnstown limestone member may be of value in the future for local use only in making natural cement. Its cementation index is 1.14 , which places it in class $\mathrm{A}$, according to the scheme of E. C. Eckel. ${ }^{a}$ According to Eckel, products having an index between 1.00 and 1.15 , when burned at sufficiently high temperature, are slow setting and high in tensile strength. They include the "natural Portlands". and allied products. If not burned high enough, cements 
of such low index will contain free lime and magnesia. This particular product near Johnstown stands near class B (in which the cementation indexes run from 1.15 to 1.60). In this class are included most American natural cements and nearly all European Roman cements. As a rule it is not necessary to burn these products at so high a temperature as those in class $\mathrm{A}$.

The composition of the Johnstown limestone member differs from place to place, as the following analysis of a sample collected from the vicinity of Mineral Point shows. This sample is low in alumina, magnesia, and silica and high in lime and differs from the material of the corresponding bed near Johnstown:

Analysis of cement rock, Mineral Point.

Sample collected by Lawrence Martin near Mineral Point. Analyzed at structural-materials laboratory, United States Geological Survey, St. Louis. A.J. I'hillips, analyst.]

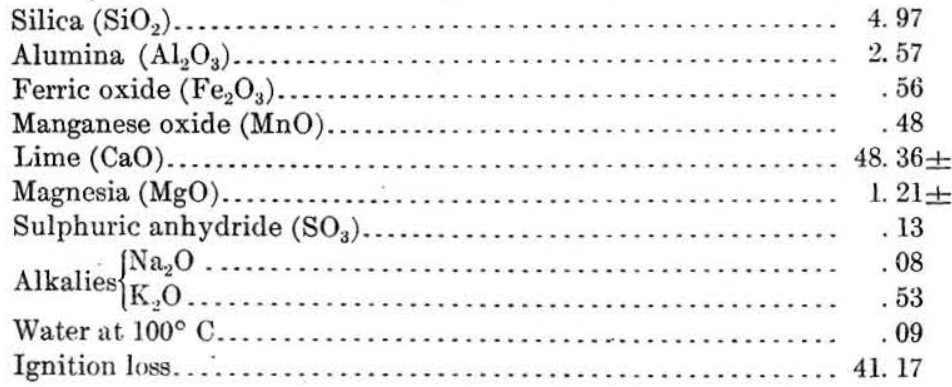

The addition of clay or shale of proper composition would be necessary to bring rock of the composition shown above to that of a Portland cement. It is almost certain that suitable clay or shale exists in the locality. The comparative thinness of the bed will militate against its extensive use. After it has been worked some time along its outcrop it will have to be mined underground. The expense attached to such operations would prevent competition except for purely local purposes.

BUILDING STONE, PAVING BLOCKS, AND CONCRETE MATERIALS.

The only rock suitable for building stone in the Johnstown quadrangle is sandstone, and of this rock there is a great abundance. Locally it has proved of great value in the construction of culverts, bridges, etc., along the Pennsylvania Railroad and in the construction of dwellings; but as a rule it will not bear the cost of very distant transportation. The gate at the entrance to Grandview Cemetery, Johnstown, is an example of the application of this local rock for construction purposes.

The sandstones of the Conemaugh have been used in certain parts of the quadrangle in the construction of dwellings. In the north-

$$
69516^{\circ}-\text { Bull. } 447-11-9
$$


eastern part the Morgantown ("Ebensburg") sandstone member has been so used with very satisfactory results. In the hills about Johnstown the Mahoning sandstone member is exceedingly massive in places and is capable of furnishing dimension stone of sizes suitable for the foundations of houses and for culverts, bridges, chimneys, etc. A great deal of this sandstone has been quarried from the outcrops of the Mahoning sandstone member, especially in the hills east of the city, and used for the purposes enumerated.

The Pottsville formation is made up almost entirely of sandstone. It has been quarried along the main line of the Pennsylvania Railroad and used for construction purposes and in the manufacture of concrete. The Conemaugh Stone Company formerly quarried it for use in construction along the Pennsylvania Railroad from a quarry on the south side of Conemaugh River, a few miles southeast of Conemaugh Furnace. The Pottsville formation outcrops along the Pennsylvania Railroad also near South Fork, Mineral Point, and east of Johnstown, also on the Baltimore and Ohio Railroad near Paint Creek and farther south. The sandstone is in most of these localities a pure coarse-grained or gritty rock, usually weathering to a gray or gray-white rock of pleasing appearance. It seasons rapidly and firmly and withstands the eroding action of the elements in a manner to make it of great value as a building stone.

West of Coopersdale the sandstones of the Pottsville formation are quarried and crushed for use in concrete. The quarry is owned by A. B. Cooper, who also controls a quarry on the Loyalhanna limestone member in the lower part of the hill. The limestone is crushed for use in concrete and is also used for paving blocks. The quarry on the sandstone is located a few hundred feet above the tracks of the Pennsylvania Railroad on the north side of the river. The sandstone is very pure and is decidedly coarse grained to gritty in texture. It is blasted out without much regard to the size or shape of the product, the only requirement being that the fragments be as small as possible. The larger pieces are broken up and the stone is removed to the mill on the railroad by means of small cars moving on an inclined plane and controlled by a stationary engine at its foot. At themill the sandstone is crushed by two crushers having a capacity of 100 and 300 tons a day of ten hours. It is then conveyed to a wet pan, in which it is further reduced in size and thence passed through screens of the proper size, from which it is conveyed by a bucket conveyor diractly to the cars.

Another rock used in the manufacture of concrete is the Loyalhanna limestone member, which (see p. 29) occurs at the top of the Pocono formation. It is about 45 feet thick in the Johnstown quadrangle. It is not a true limestone but rather a sandy limestone. It weathers 
in a peculiar and characteristic way, well shown in Plate VI, $A$, page 28. This siliceous limestone is quarried and split into paving blocks which give satisfaction, and is crushed for use as ballast in railroad beds. For both uses it is well adapted, as its calcareous portion on solution and recrystallization tends to bind the fragments solidly together and yet leaves sufficient space between them to allow the free circulation of water. The siliceous limestone exposed near the viaduct between Mineral Point and South Fork has also been quarried for paving blocks.

\section{GLASS SAND.}

The question has been raised whether the pure sandstone occurring in the Pottsville formation in the Johnstown quadrangle might not be used in the manufacture of glass, especially bottle glass. Sand or crushed sandstone, as is well known, is the major constituent of glass, forming from 52 to 65 per cent of the mass of the original mixture, or from 60 to 75 per cent of the finished product. To the sand is due the absence of color (according to its purity), the transparency, brilliancy, and hardness of glass. For the finest flintware, such as optical and cut glass, only the purest sand can be employed. For plate and window glass, which are commonly pale green, absolute purity is not essential, but generally the sand should not carry more than 0.2 per cent of iron oxide. Green and amber glass for bottles, jars, and rough structural work can be made from sand relatively high in impurities, but an excess of iron is to be avoided by careful selection. Washing may be necessary to remove the iron, and magnetic separation may have to be employed. Clay in the raw material is objectionable, as it clouds the glass, but it may be removed in part by washing. Magnesia is troublesome because it makes the batch difficult to fuse. If a sandstone is used as a source of glass sand, it should be friable, so as to be readily crushed.

The sandstone derived from the Pottsville formation is in its original form a massive rock, in some places friable but in others not; the less friable portions are, however, readily crushed. In many parts of the quadrangle the sandstone of the Pottsville fills all the requirements of a glass sand for the manufacture of bottles, jars, and rough structural material; where the amount of oxide of iron is excessive it may be corrected by the addition of small amounts of manganese dioxide or other decolorizing agents. The following analysis of a sample of friable sandstone from the Pottsville formation, collected on the west flank of Laurel Ridge, not far from Seward, shows the character of this sandstone at this point, and it is quite probable that sandstone of equally great purity may be collected at other points where the Pottsville outcrops in this area: 
Analysis of glass sand from Pottsville formation on west flank of Laurel Ridge, near Sewarll. [Made by A. J. Phillips at the structural-materials testing laboratory of the United States Geologicil Survey at St. Louis, Mo.]

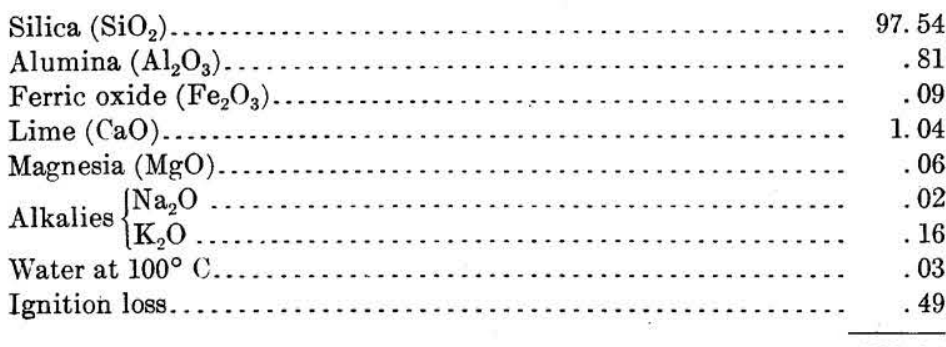

100. 24

The amount of impurities is notably small. Iron oxide falls well within the outside limits demanded for bottles, jars, and rough structural material. The amount of clayey material is very small, as is also the magnesia.

The sandstone of the Pottsville should offer no serious obstacle to being ground to the requisite fineness (say to pass through a 20 to 50 mesh sieve). In prospecting for glass sand only the clearest and whitest sand should be selected, and before exploitation complete quantitative analyses and furnace tests of representative samples should be made.

\section{IRON ORES.}

HISTORY.

But one bed of iron ore in the Johnstown quadrangle deserves mention, and that one is now of historic interest only. The interest attached to the ore is, however, great, for its presence in the hills near Johnstown was perhaps the main factor in determining the location of the present great plant of the Cambria Steel Company, which sought this position for its works owing to the close association between the ore and the underlying coal beds. With the appearance of the cheap Lake ores on the market the Johnstown iron ore ceased to be of importance. At present it is not worked, and very little firsthand information is to be obtained regarding it. The following notes are simply a compilation from the report of the Second Geological Survey of Pennsylvania ${ }^{a}$ and are given here to make this report of the mineral resources of the Johnstown quadrangle complete

JOHNSTOWN ORE BED.

EXTENT.

The Johnstown ore bed is found in the center of the Johnstown Basin. Its eastern outcrop appears a short distance west of Conemaugh depot, where it occupies a position well up on the hillsides 
above the railroad. Thence it descends slowly westward, approaching water level at Hinckston Run, and after crossing the synclinical axis it again rises toward the Laurel Ridge anticline and comes to the surface on the eastern flank of Laurel Ridge. In the hills along the south bank of the Conemaugh it has never been found, although repeated search has been made for it. Its horizon has been determined may times and the vertical distance between it and the upper Freeport (Coke Yard) coal has been accurately measured. At Johnstown this interval is about 50 feet. This same iron-ore bed is known to exist on Mill Creek southeast of Johnstown, where it was benched for many years prior to 1875 by Dr. Schoenberger, the ore furnishing the material on which two small furnaces were run. The same ore was mined near and smelted at the old Cambria furnace, near the base of Laurel Hill.

\section{CHARACTER OF THE ORE.}

The ore bed at the opening of the Cambria Company's mine on the west bank of Hinckston Run was divided into two bands by a stratum of fire clay or shale which ranged from an inch to a foot in thickness and which crumbled when exposed to the weather, losing its water slowly and changing in color. The upper bench was much richer in iron than the lower, the latter being calcareous; but the ore from both benches contained sufficient lime to flux and was charged into the furnace with the coke without limestone. The ore yielded about 30 per cent of metallic iron when carefully treated in the furnace, but sometimes ran below this figure and occasionally rose above it. Its character is expressed by the following analyses, furnished by $\mathrm{T}$. T. Morrell:

\section{Analysis of iron ore from Johnstown bed.}

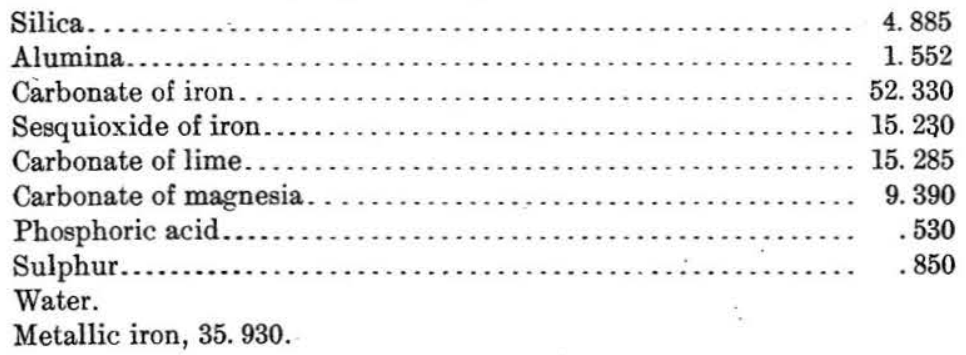

Mr. Morrell reports finding also a strong trace of manganese. The ore was calcined before being used in the furnace; the calcination was carried out in large open heaps near the mine, at an expense of about 10 per cent of fuel. The following analyses by Mr. Morrell show the general character of the ore after calcining, from both the upper and lower benches: 
Analysis of calcined iron ore from Johnstown bed.

\begin{tabular}{|c|c|c|}
\hline 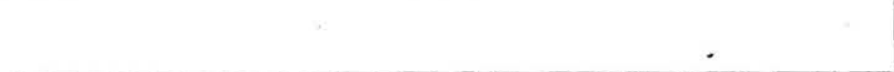 & $\begin{array}{l}\text { Upper } \\
\text { bench. }\end{array}$ & $\begin{array}{l}\text { Lowrer } \\
\text { bencti. }\end{array}$ \\
\hline 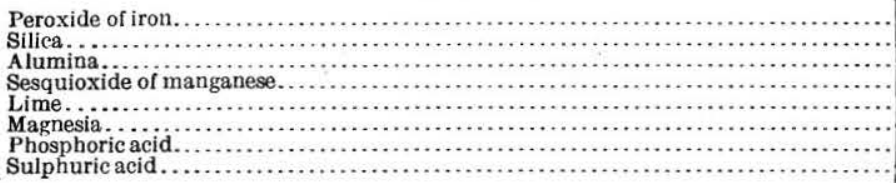 & $\begin{array}{r}77.64 \\
7.34 \\
1.02 \\
1.39 \\
10.10 \\
1.01 \\
.99 \\
.52\end{array}$ & 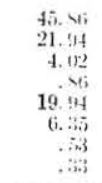 \\
\hline & 100.01 & $99 . \times 5$ \\
\hline 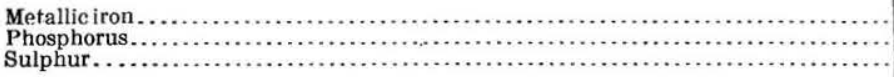 & $\begin{array}{r}54.350 \\
.424 \\
.210\end{array}$ & $\begin{array}{r}32.110 \\
.2: 2 \\
.1 \% 3\end{array}$ \\
\hline
\end{tabular}

PHYSICAL FEATURES OF THE ORE BED.

The ore bed is invariably underlain by shale and the roof is chiefly of the same material, being locally replaced by massive sandstone containing lumps of carbonate ore. The roof shale shows a decided tendency to crumble, and after the ore has been removed it sinks steadily, gradually reducing the height of the gangways. This behavior of the roof has been a source of constant annoyance, and has required the closest watching to avoid accidents. To counteract the sinking, "shanties" 4 feet high, consisting of strong timbers laid crosswise, are constructed at short intervals. In places these powerful logs are crushed so tightly together as not to exceed 2 feet in height. The irregularities of the bed are perhaps one of its most striking features. These irregularities consist of "rolls" and "horsebacks," which, though numerous, do not interfere with the general plan of working the ore. The system employed in mining is known as the long-wall method, the best and most economical of all systems wherever practicable. (See pp. 105-112.) By this'method the ore is taken from along a line of wall which as it advances includes within a certain distance all the ore under the hill as far as the point reached.

The ore oxidizes rapidly at the outcrop, changing from a dove color to a rich brown, the former being the color of the unaltered carbonate, the latter of the hydrous oxide, or limonite, resulting from the oxidation of the carbonate. The average thickness of the ore at the Hinckston Run mine is about 2 feet; it changes, however, in thickness abruptly, the upper band thickening and the lower thinning, and vice versa. The following measurements made at different points in the mine serve to show the varying thickness of the ore bands. The third section was measured at a distance of 10 feet from the place where the second measurement was made, and the fourth 15 feet still farther southwest. 
Sections of Johnstown ore bed.

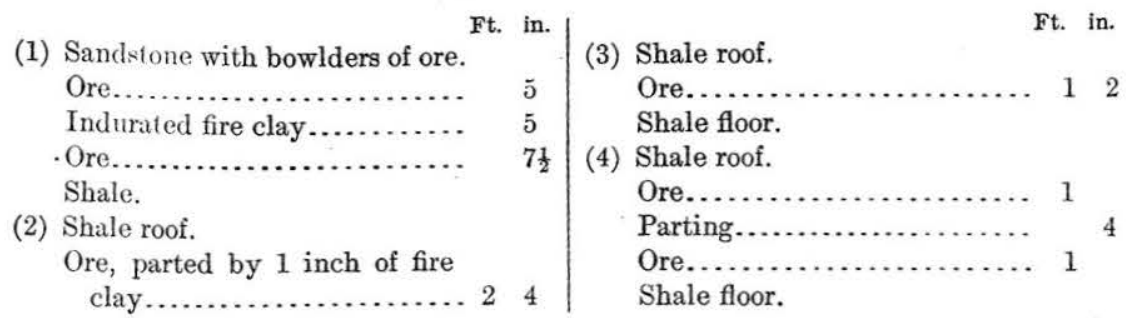

WATER RESOURCES.

The Johnstown quadrangle is a well-watered region. Most of the towns derive their water from the headwaters of the smaller creeks flowing into the main drainage channels-Stony Creek, Conemaugh and Little Conemaugh rivers, and Blacklick Creek with its North and South branches. These streams are fed by multitudes of springs as well as by the ordinary rainfall. This water is stored in reservoirs to insure a constant and adequate supply. The water is excellent, because the slopes from which most of it comes, though of small extent, are in general well wooded and comparatively free from habitation. The city of Johnstown obtains its water chiefly from three storage reservoirs, two on Mill Creek and one on Dalton Run. South Fork obtains its supply from a storage reservoir on Sandy Run. The town of Wehrum procures water from a reservoir on Rummel Run, and it is understood that the town of Vintondale also has a reservoir on a stream to the southeast. The town of Windber and associated mining villages, lying in part within the Johnstown quadrangle, are supplied partly from a storage reservoir on Little Paint Creek. For industrial purposes the Cambria Steel Company has constructed a large reservoir on Hinckston Run. During most of the year the flow of the streams is fairly adequate, but during the dry season of the autumn the supply is likely to run low. During the summer of 1906 the streams all maintained a good flow of water.

Away from the railroads the inhabitants of the region depend mostly on wells. Many of these wells have been driven as far down as coal beds, which are almost universally in water-bearing zones. The water obtained from such beds is commonly sulphurous and generally considered very wholesome. Springs are very abundant but do not appear to be large. The springs generally issue from coal beds or just above impervious clay beds. Though the volume in most such springs is not large, in purity the water can not be excelled. Many of the drill holes put down in this area have tapped waterbearing beds, but almost all the drillings have been made in search 
136 MINERAL RESOURCES OF JOHNSTOWN, PA., AND VICINITY.

of coal beds, and little or no attention has been paid to the waterbearing strata. These usually have been either sandstone beds or coal beds. Such a hole was drilled near the confluence of North Fork and South Fork of Bens Creek in Somerset County, near Mishler. The locality is known as Sulphur Springs. The water probably issues from the Upper Kittanning coal bed, as the drill hole is understood to be very shallow. 


\section{INDEX.}

A.

Allegheny formation, chargeter and distribution of ...................... 22-27, 44 clays in.............................. 114 brick from....................... 114 coals in... 22-27, 44-61, 64-78, 80-91, 92-95, 96-101 See also particular coals.

limestones in ...................... 126-129

sections of .................... 22-23, 27,92 figure showing.

shales in ........................... 115

Alluvium, occurrence and character of....... 15

Ashley, G. H., work of.

\section{B.}

Baltimore and Ohio Railroad, bench marks along...

Barnesboro syncline, description of ............

B coal. See Lower Kittanning coal.

Bear Rock Run, coal at, analysis of.

Beaverdale, coal at, section of, figure showing.

Beaverdam Run, coal at, section of, figure showing....

Bench marks, location of ....................

Bennington, coal at..

coal at, analysis of ...................... coking of....

Bens Creek, coal on . coal on, analysis of. section of, figure showing

Bens Creek (South Fork), coal on.............

Beulah Road, bench mark on................

Big Bend, coal at........................ 79,81

section at...............................

Blacklick Creek, coal on................. 22, 80-81

rocks on ........................... 20

section on, figure showing.............. 24

Blacklick Creek district, clays of... 113-114, 124-125 coals of ............................... 80-95 position of.......................... 79-80

extent of............................. $78-79$

Blacklick Creek seam. See Lower Kittanning coal.

Bolivar clay member, character and distribution of......................... 25

Brick industry, firms engaged in............. 156

Briquetting tests, results of.......... 87-88,99-100

Brookville coal, character and distribution of. 23,

sections of $27,41-42,60-61,77-78$

figures showing ................. 60, 24,78

See also Dirty A coal.

Buffalo sandstone member, character and distribution of.......................

section of.....

Butler sandstone member, character and distribution of.
Cambria, coal at and near.

c.

Page. coal at and near, section of, figure show-

ing. ...

Carboniferous system, occurrence and character of ................... 16-29

Catskill formation, character and distribution of......................... 29 section of .............................. 30

C coal, position of ......................... 80 See also Middle Kittanning.

$\mathrm{C}^{\prime}$ coal. See Upper Kittanning coal.

Cement. See Portland cement.

Cement coal. See Upper Kittanning coal.

Cement rock, natural, analyses of.......... 128,129

Chickaree, triangulation station at.......... 11-12

Clapboard Run, elay on................... 117 coal on ..................... 49, 53, 58,59,60 sections of...................... 60 figures showing............. 50,55, 59

section of, figure showing .................. 24 structure near........................... 34

Clarion coal, character and distribution of. $23,27,61$ section of......................... 90,91, 92 figures showing.................. 24,61

Clay, character and distribution of ........ 113-126 See also Flint clays; Plastic clays.

Clay industry, firms engaged in.......... 125-126

Coal, mining of, bibliography of............ 113 mining of, description of.............. 102-112 figures showing........... 103,106, 107, 108 occurrence and character of............. 35-101 Coal deposits, description of, by districts... 42-101 Coke Yard coal. See Upper Freeport coal.

Coking tests, results of............. 72-73, 85, 98-99 Conemaugh formation, character and distribution of ................. 16-22, 43 clays in........................... 113,114 coals in................ 19, 20-22, 43-44,62-64 limestone in ......................... 126 members of, description of............. 18-22 sandstones of ....................... 129-130 view of ......................... 20 sections of ............... 16-18, 21-22, 115-116 shales in.......................... 115 Conemaugh Furnace, coal from ............ 101 coal from, analyses of .................... 41-42

Conemaugh Furnace district, clays of........ 114 coals of ............................. 96-102 extent of .............................. 96

Conemaugh River, clays on.............. 121 coals on....... $49,51,53,56,57-58,65,67,69,96,97$ commerce by ........................ $9-10$ description of.......................... 9,11 limestone on......................... 127 rocks on ........................... 15, 28, 29 sections of ............................ 30 figure showing.................... 101 
Conemaugh slope, coal from ............. 4.49 coal from, analysis of ................. 42 section of figures showing......... 50,59

Conglomerate rock. See Pottsville formation.

Connoquenessing sandstone member, character and distribution of .......... 27-28

Contours, structure, explanation of . ....... 30-31

Conveyor method, description of.......... 105-112

Conveyors, description of............... 109-110

Coopersdale, clay at..................... 118 coals at and near............ 27, 48,51,57,60 section of, figure showing........... 59 sandstones near..................... 130

section at.......................... 23 figure showing................... 24

Cramer, coal near, section of.............. 96

Cupola tests, results of................ $73-75$

D.

Dale, coal at..................... 52, 54, 56 coal at, analysis of................. 40,42 sections of, figures showing ...... 50,52,55

Dalton Run, clay on................... 117 coal on .............................. 25,54 section of ....................... 26 sections of, figure showing.......... 55

D coal. See I.ower Freeport coal.

Devonian system, occurrence and characterof. 29-30

Dilltown, clay near...................... 124 clay near, analysis of ................ 124

coal near.......................... 79,83 section of, figure showing .......... 89

D'Invilliers, E. V., on coals ........ 80,82-83, 92 on structure ................ 82

Dirty A coal, analysis of................. 41 character and distribution of........... 39-40 See also Brookville coal.

Drainage, description of ................. 9-10 relation of, to structure............... 10

Drainage, mine, methods of.............. 104

Dunlo, coal at, section at, figure showing....

E.

East Conemaugh, coal near, section of, figure

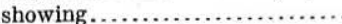
section near.

Ebensburg, triangulation station at..........

Ebensburg quadrangle, coal of............... coal of, analyses of ............... 67,70

Ebensburg sandstone. See Morgantown sandstone member.

E coal. See Upper Freeport coal.

Economic geology, account of........... 35-136 map showing..................... Pocket.

Ehrenfeld, coal at and near.......... 37, 65, 66,73 coal at and near, analysis of......... 41-42,76 coking of ...................... $38,72,74$ cupola tests of ................. $73-75$ section of, figure showing.......... 66 producer-gas tests of ................ 76

limestone near..................... 126-127 rocks at and near................ 20,21,25 sections at....................... 21-22, 65 figure showing.................... 77 shale near ........................... 123
Fage

Elevations, location and height of......... 10-1]

Elton, coals near....................... rocks near............................

Expedit post office. See Twin Rocks.

\section{F.}

Falls Run, coal at...................... 58

Ferndale, coal near...................... 5 :

"Ferriferous limestone," correlation of....... 127

Flint clays, analyses of ............. 121, 122, 124 character and distribution of........... 113$117,121-123,124,125$ sections of .................. 115-116,122,125 Four-foot coal. See Upper Freeport coal.

Foustwell, coal near................... 59,60 section near.......................... 27

Franklin, coal at and near........ 51,53,58,59, 60 coal from, analysis of............... 40,42 coking of ......................... 39 sections of, figures showing ......... 55,59 structure near....................... 34

Frankstown, coal near................. 53, 60 coal near, section of, figures showing..... 50,57

Fulton, John, work of..................

Fye place, triangulation station on........ 13

G.

Gallitzin, coal near...................... 65 coal near, section of, figure showing..... 66 Gallitzin coal, character and distribution of.. $\quad 20$, 43,64

Geography, outline of................ 9-10

Glass sand, analysis of.................. 132

character and distribution of.......... 131-132 Greenbrier limestone, character and distribution of......................... 29

Grubtown, coal at, sections of, figure showing. $\quad 50$

H.

Harlem coal, character and distribution of... 19

Haulage, methods of ................ 104-105

Headings, character of.................... 102

Hinckston Run, coal on.................. $\quad 49$ coal on, section of, figure showing....... 50

iron ore on ....................... 133

Homewood sandstone member, character and distribution of $\ldots \ldots \ldots \ldots \ldots .27-28$

I.

Ingleside, bench mark at................ 14 coal near........................ 43,57 sections of, figures showing . ......... 59,93

Ireland, W. G., work of ................. 73

Iron ores, history of . . . . . . . . . . . . . . . 132, 133 location of.......................... 18, 132 See also Johnstown ore.

Island Park, coal near.................. $\quad 43$ coal near, section of, figure showing...... 50

J.

Johnstown, bench marks at and near....... 14 clays near......................... 116 coals in and near......... 25, 26, 35, 43, 58-59 analyses of .................... 40,42 sections of ....................... 26 
rage.

Johnstown, coals in and near, sections of, figures showing.

$50,55,59$ rocks near . sections near............. 17-18, 22-23, 115-116 shales near......................... 115

water supply of.................... 135 Sec also Johnstown district.

Johnstown Basin, description of............ 32,33

Johnstown distriet, clays of........... 113,115-119 coals of analyses of ...................... $40-42$ sections of figures showing....... 50,52,55 description of ......................... 42 shales of........................ 115, 119-121 analyses of . . . . . . . . . . . . . brick from...................... 119

Johnstown limestone member, character and distribution of ............ 26, 127-129

clay below........................... 117 analysis of...................... 117 limestone of ...................... 127-129 analyses of ..................... 128

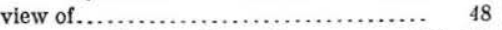

Johnstown ore bed, analyses of.......... 133, 134 character and distribution of. 18,21,126,132-135 sections of ............................ 13.5 Johnstown syncline, description of 32,33

K.

Kernville, elay at....................... 118 coals in and near............... 53,56, 57, 58 sections of, figures showing........ 52,59 section near ............................ 46

Kittanning sandstone member, character and distribution of...................

Kring, bench mark at..................... 14 clay near........................... 119 coal near................ 26, 28, 43,54,56, 58, 61 section of...................... 61 figure showing................... 55 limestone near, analysis of............. 128 rocks near........................... 15, 26

\section{L.}

Laurel Ridge, clays on............... 115,116,125 glass sand on, analysis of............. 132 iron ore on............................. 133 location and occurrence of .............. 10 rocks on ........................... 28,29

Laurel Ridge anticline, description of........ 33-34

Laurel Run, coal on....................... 57 coal on, section of, figure showing ....... 59 limestone on............................ 127

Lemon coal. See Upper Freeport coal.

Limestone, analyses of.................. 128, 129 character and distribution of .......... 126-129

Limestone coal. Sec Lower Freeport coal.

Little Conemaugh River, structure on...... 34

Llanfair, coal at........................ c9 coal at, analysis of .................... 70 section of ........................ 77

Lloydell, coal from, analyses of........... 37,70

Long-wall system, description of........... 105-112 figures showing................ 106,107, 108 rocommendation of................... 105
Page.

Lower Allegheny coals, character and distribution of..................... 39 $40,60-61,77-78,89-91,95$

See also Brookville coal; Clarion coal; Dirty $\mathrm{A}$ coal.

Lower Freeport coal, character and distribution of...... 25, 35, 51-52, 67, 80-82, 93, 96

sections of ...................... 22,44,46

figures showing................ 24,52, 81

view of ............................... 24

Lower Freeport limestone member, character and distribution of........ 25, 127

view of

Lower Kittanning clay member, character and distribution of............. 27

Lower Kittanning coal, analyses of .......... 36-37 $40-42,58,69-70,71,73,76$

$84,85,86,87,88,95,97,99,100$

briquetting tests of............ $87-88,97,99-100$ character and distribution of. .. $27,34,36,57-60$, $69,76-77,82-83,88,94-95,97,101$

clay below................. 117-118, 123,125

analysis of ...................... 118

coke from, analyses of . .............. 73, 85,99 coking tests of ......... 38-39, 58, 72-73, 85, 98-99 cupola tests of ....................... 73-75 producer-gas tests of................. 76,86

sections of ............... 23,47, 48, 77,79,101

figures showing......... 24, 59,77,89,95, 101 steaming tests of ........... $70-72,83-85,97,98$ structure map of.................... Pocket.

explanation of ...................... 30

washing tests of .................... 86-8i, 99

"Lower Productive Coal Measures." See Allegheny formation.

Loyalhanna limestone member, character and distribution of ............. 29

use of, for concrete................. 130-131

view of ........................... 28

M.

Mahoning coal, character and distribution of.. 22, 43,64

section of .......................... 4

Mahoning sandstone member, character and distribution of................. 20-22

sections of .......................... 18,21-22

use of, for building................. 130

Map, economic and structural, of Johnstown quadrangle ................. Pocket.

Map, index, showing position of Johnstown quadrangle................... 9

Mardis Run, clay on ................. 25, 114, 124

coal on......................... $79.80,81,82$ section of, figure showing........... 81

Martin, Lawrence, work of ................. 9

Mauch Chunk shale, character and distribution of...................... 28-29 sections of ............................ 28, 29 view of .............................. 28

Mercer coal, character and distribution of.... 61 section of .......................... 61

Mercer shale member, character and distribution of...................... 27-28 clays of................. 114, 119, 121-122, 125 
Page.

Mercer shale member, clays of, analyses of. 121, 122 clays of, section of .............. 119, 122, 125 quarry on, view of..................... 28 section of ............................ 125 shale of..................... 120-121, 125 analysis of ...................... 121

Middle Kittanning coal, character and distribution of .....26, 44, 56-57,82,94,96 sections of ...................... 79,82,96 figure showing.................... 24

Mill Creek, clay on ....................... 117 coal on. . . . . . . . . . iron ore on ........................ 133 section on......................... 45

Miller coal. See Lower Kittanning coal.

Mineral Point, coal near.............67,77-78 coal near, sections of, figures showing... 68,77 view of . . limestones at, analyses of ............. 129 rocks near ............................ 15

Mineral Point district. See South ForkMineral Point district.

Mineral resources, description of ......... 35-136

Mining, facility of ...................... 10

Mississippian series, occurrence and character of.......................... $28-29$

Morgantown sandstone member, character and distribution of ............. section of.

Morrellville, coal near................. 54,58

Moxhom, coal near.................. 54,56,93 coal near, analysis of................. 40,42 sections of, figures showing....... 50,55

limestone near.......................... 127

N.

Nanty Glo, bench mark at.

$78-79,80,81-82,83$ analyses of.................... 40,42 coking of ........................ 39 sections of, figures showing . ....... 81,89

New Germany, coal near................. 67

\section{P.}

Paint Creek, coal near

60,94 rocks near.................... 15,28,60-61 sandstone near...................... 130 section near........................ 28

Peggys Run, coal on............. 51, 53,56,58, 60 section on, figure showing.

Pennsylvania, cooperation with.

Pennsylvanian series, occurrence and character of ...................... 16-28

Phalen, W. C., work of .................. 9

Pillars, details of....................... 103

Plastic clays, analyses of............... 117,118 character and distribution of ........ 114-115,

$117-119,123,125$

sections of

Platt, Franklin, on Summerhill mine....... 62-64

Pleasant Hill, clays on................... 116

Pleistocene deposits, occurrence and character

$$
\text { of. }
$$

Pocono formation, character and distribution

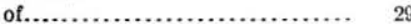

topography of ......................... 10

Portland cement, materials for............ $\quad 26$

Pottsville formation, character and distribution of..................... 27-28

coals of .............................. 61,78

sections of ...................... 61,78

See also Mercer coal.

glass sand from................... 131-132

analysis of....................... 132

sandstones of ...................... 130

section of ........................... 28

topography of ..................... 10

Producer-gas tests, results of ............ 76, 86

Prospect Hill, shale on.................. 120

Prossers Knob, coal in..................... 43

section of......................... 17-18

Puritan, coal at, analysis of............... 68

coal at, section of, figure showing........ 66

Q.

Quaternary system, occurrence and character of ............................. 15

R.

Recent deposits, occurrence and character of. 15

Red shale, character and distribution of.... 19,20

Relief, description of.................... 10-11

Rexis, coal near....................... $\quad 80$

coal near, section of, figure showing...... 81

River deposits, occurrence and character of.. 15

Room and pillar system, description of... 102-105

Rooms, character of .................. 102-103

Roxbury, coal at, section of, figure showing. . $\quad 50$

Rummel Run, coal on, section of, figure show-

ing.

S.

St. Clair Run, coal on .............. 49-50, 58 coal on, section of, figure showing ....... 50,59

Salix, bench mark at..................... 14 Salt Lick Run, coal on, section of, figure show ing ......................... 68

Saltsburg sandstone member, character and distribution of................ 19-20

Sams Run, coal on ................ 49,52,54,56 coal on, sections of, figures showing... 50,52,55 Sandstone, character and distribution of. . 129,131 use of, for building.................... 129 Sandy Ridge, clay from, analysis of......... 112 Scalp Level, bench mark at................ 14 coals near....................... 91,92 analysis of..................... 41-42 limestone at......................... 127 section at............................ 92

Seidel, George, work of .................. 13

Seward, bench mark at.................... 14 clays at............................. 114 coal at........................ 96,97,101 analysis of..................... 37 coking of ....................... 38,39

section of, figure showing .......... 101 glass sand near, analysis of ........... 132 
Page.

Shale, analyses of character and distribution of .......... 113,

$115,119-121,123$

Sherbine farm, triangulation station on ...... 12-13 Sheridan, elay near................ 114-115, 119 coal near.

quarry near, view of.................... 28

rocks near............................ 15

shale near.................... 115, 120-121 analysis of....................... 121

Shingle Run, clay on .................... 116

Six-foot coal, analysis of.................. 41 character and distribution of .......... 39-40 See also Brookville coal.

Solomons Run, coal on .......... 49, 52, 54, 56, 58 coal on, analysis of ................. 40,42 section of, figures showing...... 52, 55,57

South Fork (town), clay at.......... 121-122,123 clay at, section of................... 122 coal at and near..............6. $67,76,77-78$ production of.................... 69 sections of, figures showing..... $68,77,78$

limestone near................... 126-127

rocks at and near................... 20,25

section at, figure showing.

24

water supply of .................... 135

See also South Fork-Mineral Point district.

South Fork (river) coals on..... 35, 36, 64,65, 70,92 coals on, analyses of . ........... 40,41-42,70 sections of, figure showing......... 66

dam on, view of .................... 20 rocks on .......................... 62

South Fork-Mineral Point district, clays of ... 113,

$114,121-123$

coals of.

$25,62-78$

position of........................... 62

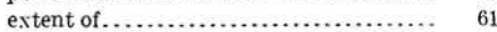

shales of .

Spirit leveling, progress of .............. 13-14

Springs, character and distribution of....... 135

Steaming tests, details of. ........ $70-72,83-85,98$

Steaming value, comparative, of coals...... 37

Stony Creek, bench mark on ............. 14

clays on ......................... 114,116

coal on and near. analyses of. . . . . . . . . sections of, figure showing......... 52 views of. ...................... 24,48 description of....................... 10

limestone near..................... 127 rocks on ..................... 15, 20,25, 26,28 sections on .................. 44,46-47,48 figures showing................. 50

Stratigraphy, description of ............ 14-30

Structure, representation of.............. 30-31 Structure in Johnstown quadrangle, descrip-

tion of...................... 31-34

map showing.

Pocket

relation of, to drainage.................. 10

Summerhill, coal near.................. 62-64

coal near, analyses of ................63,64

section of ......................... 63

rocks near.
Summerhill sandstone member, character and distribution of. ............... 18-19

Surveys, description of ............... 11-14

T.

Ten Acre Bridge, coal at................. 53 coal at, section of, figure showing....... 55

Thomas, J. I., on miving at Vintondale... 108-112

Tipples, character of................... 105

Topography, description of .............. 10-14

Triangulation stations, description of....... 11-13 location of, map showing .............. 11

Trout Run, coal on ................. $68-69,96$ coal on, section of .................... 96 figure showing.................... 66

Twin Rocks, bench mark at.............. 14 coal at or near............ $80,81,82,85,89-90$ analysis of.................. 40,41,42 sections of, figures showing .......... 81,89 rocks at........................... 28 section at......................... 90

\section{U.}

Upper Freeport coal, analyses of...... 35, 40, 65-66 character and distribution of ........... 25, $35,48-50,64-67,92-93$

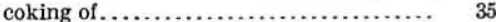
sections of ..................... 46,47,65 figures showing.............. 24,50,66

view of ........................... 48

Upper Freeport limestone member, character: and distribution of ....... 25, 126-127

Upper Freeport sandstone. See Butler sandstone member.

Upper Kittanning coal, analyses of ...36, 40,54, 67-68 character and distribution of............ 25 , $35-36,52-54,56,67-69,93-94,96$

coking of.

sections of ..................... 26,45,96

figures showing............ 24,55,68,93

views of ....................... 24,48

V.

Ventilation, methods of.................. 104

Viaduct anticline, description of ............... 33

Vintondale, bench mark at............... 14 by-product plant at................ 39 coal at or near.............. $79,80,81,82,83$ analysis of .................. 40,42 mining at, method of ............. 105-112 method of, figures showing .... 106,107,108 rocks near....................... 20 section near....................... 79,82 figure showing................ 89 water supply of.................... 135

W.

Walnut Grove, coal at................... $\quad 54$ coal at, section of, figure showing......... 55

Waisall, coal from, analysis of ...........40,42 coal from, sections of, figures showing ... 93,95 Walsall Creek, coal on, section of, figure show-

ing ......................... 93

Washing tests, cost of............... 86-87,99 


\begin{tabular}{|c|c|}
\hline & Page. \\
\hline Water resources, character and distribution & West Virginia, coals of, analyses of........... 37 \\
\hline 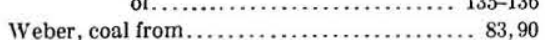 & 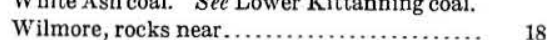 \\
\hline coal from, analysis of ................ $41-42$ & 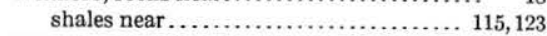 \\
\hline sections at....................... 91 & Wilmore Basin, coals in ............... 26 \\
\hline Wehrum, bench mark at................ 14 & coals in, sections of, figure showing.. \\
\hline clay near................... 113-114, 124 & 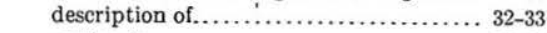 \\
\hline coal near ................... $22,79,80,83$ & section in...$\ldots \ldots \ldots \ldots \ldots \ldots \ldots \ldots \ldots$ \\
\hline analyses of........ $37,41-42,84,85,86,87,88$ & Wilmore sandstone member, character and \\
\hline briquetting tests on .............. $87-88$ & distribution of................ \\
\hline coking tests on $\ldots \ldots \ldots \ldots \ldots \ldots .38-39,85$ & Wilmore syncline. See Wilmore Basin. \\
\hline producer-gas tests on ............ $\quad 86$ & Windber, coals near $\ldots \ldots \ldots \ldots \ldots \ldots .25,35,91-95$ \\
\hline sections of, figure showing ......... $\quad 89$ & coals near, analysis of................ 41-42 \\
\hline steaming tests on ............... 83-85 & section of, figure showing ............. \\
\hline washing tests on ............... 86-87 & 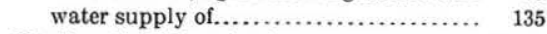 \\
\hline water supply of.................... 135 & Windber district, coals of............... 92-95 \\
\hline Wells, use of......................... 135-136 & coals of, position of . . . . . . . . . . . . . 91-92 \\
\hline Wess farm, triangulation stations on......... $\quad 12$ & extent of $\ldots \ldots \ldots \ldots \ldots \ldots \ldots \ldots \ldots \ldots \ldots \ldots \ldots \ldots$ \\
\hline Westover Basin, description of ............. & \\
\hline
\end{tabular}






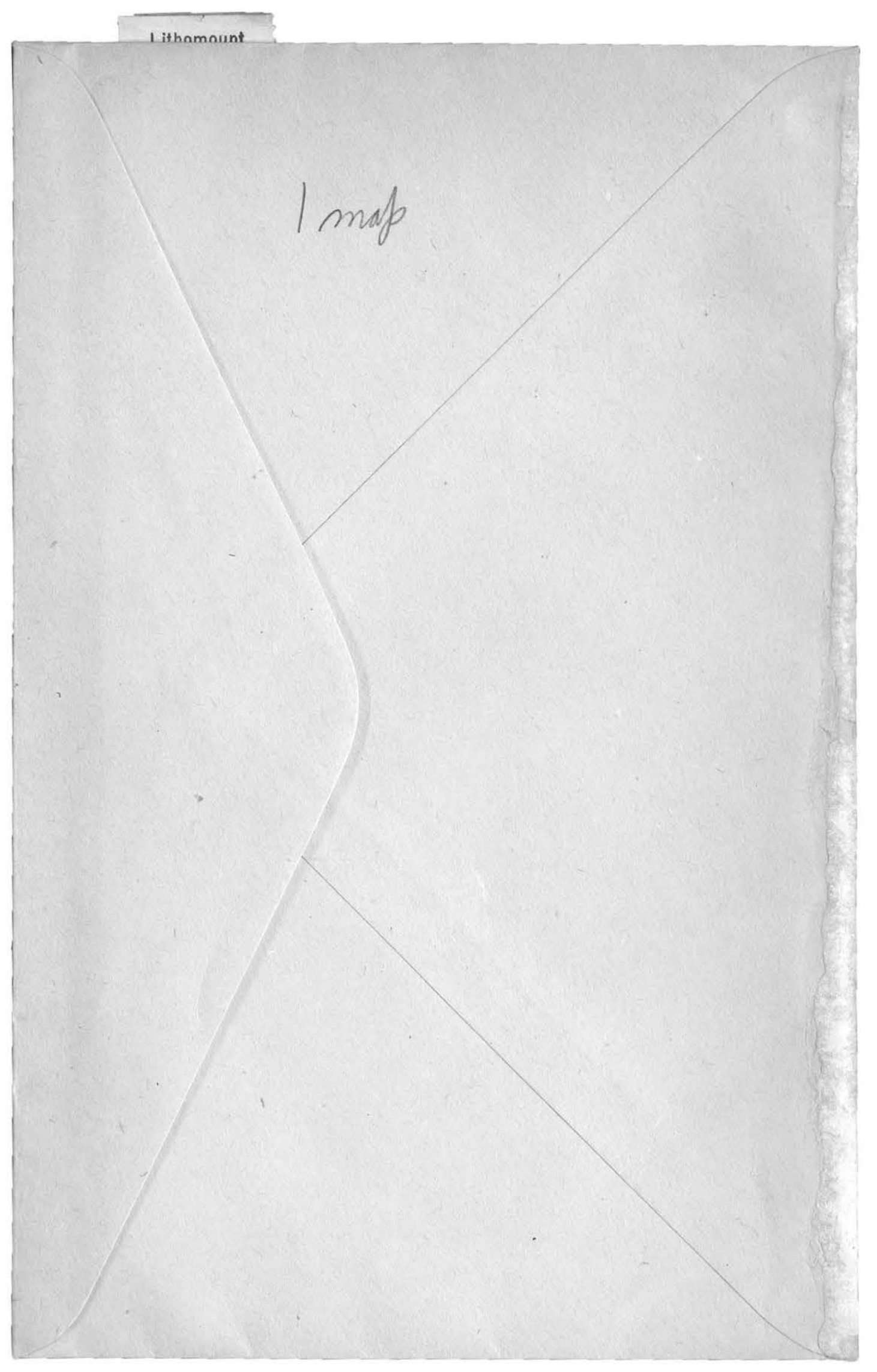




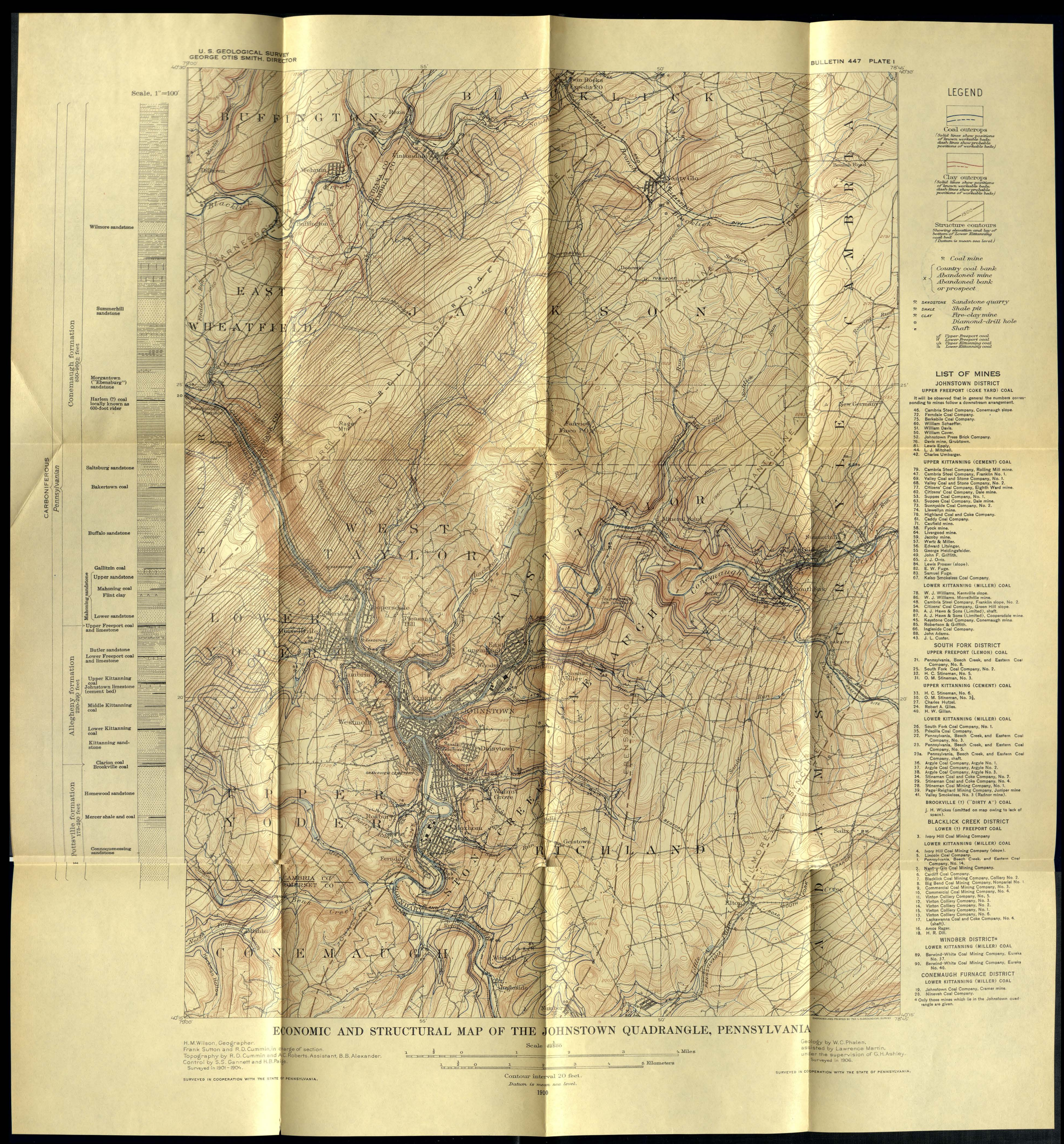




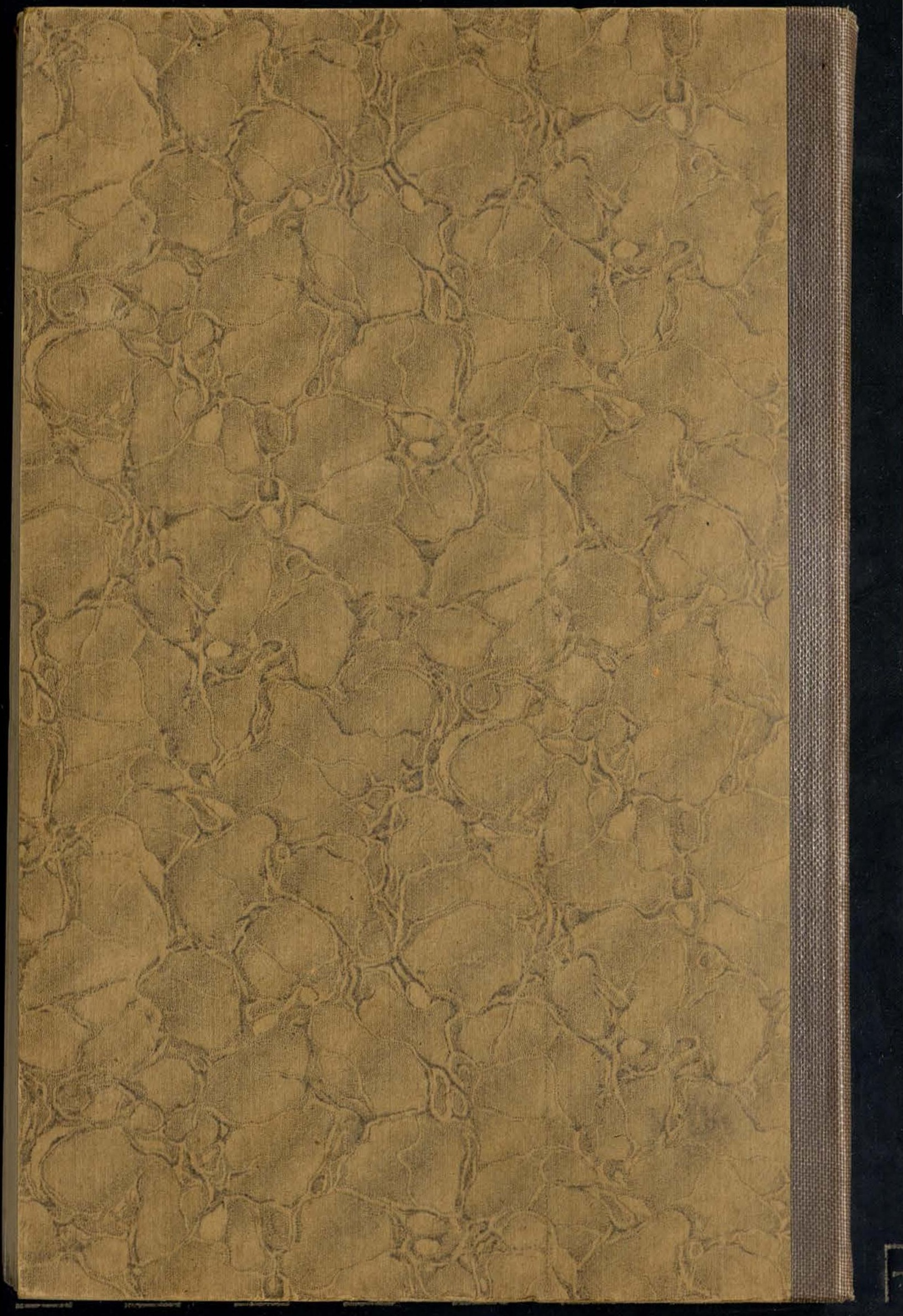

